\title{
Archaeological and Geophysical Investigations During 2007 at Larson Village, Burleigh County, North Dakota
}

\author{
Edited by Mark D. Mitchell
}
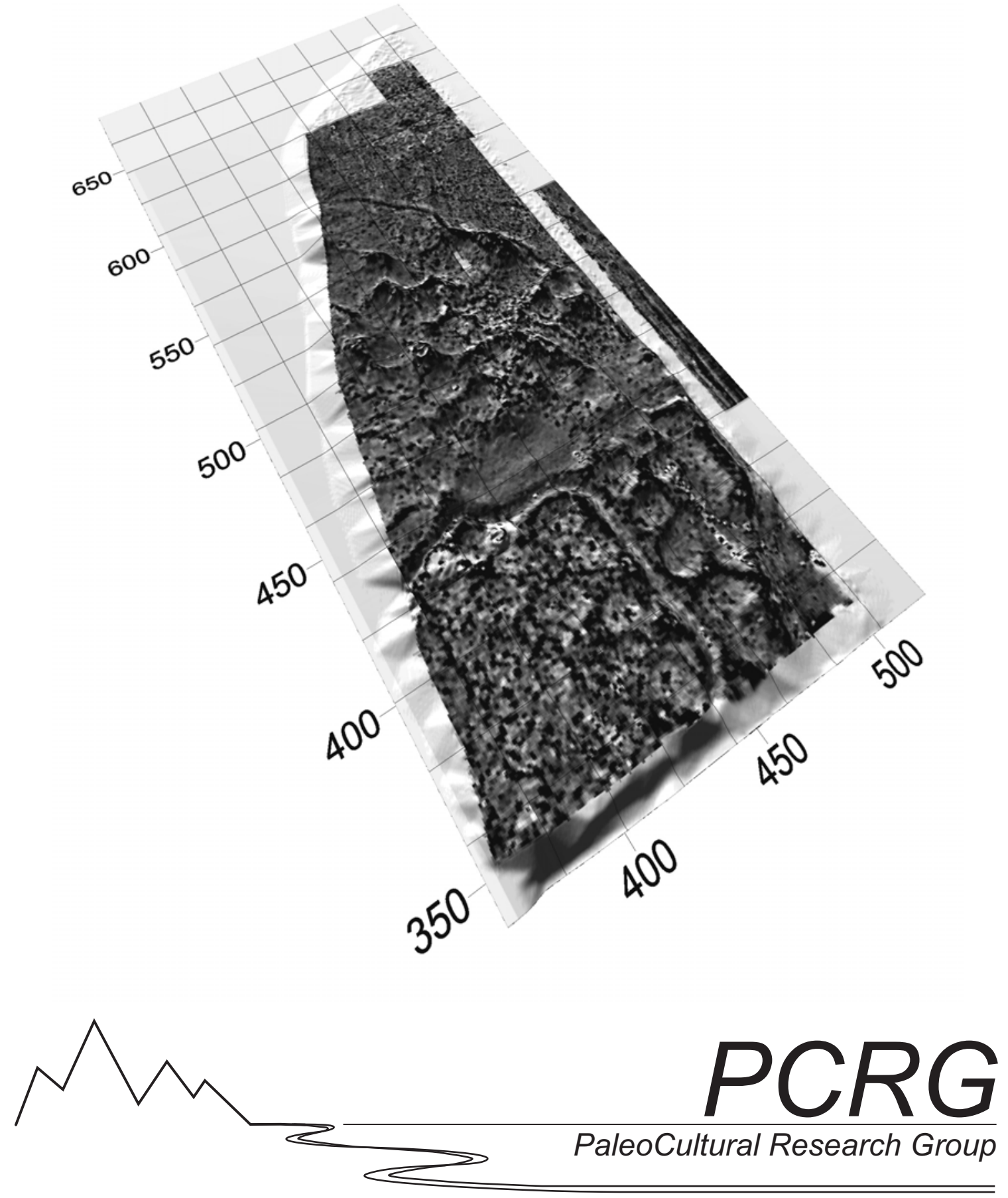


\title{
Archaeological and Geophysical Investigations During 2007 at Larson Village, Burleigh County, North Dakota
}

\author{
Edited by \\ Mark D. Mitchell \\ ORCiD ID: https://orcid.org/0000-0003-4494-8840 \\ With contributions by \\ Kenneth L. Kvamme \\ Mark. D. Mitchell \\ Paul R. Picha \\ Fern E. Swenson \\ Prepared by \\ PaleoCultural Research Group \\ 555 Burbank Street, Unit A, Broomfield, Colorado 80020
}

Submitted to the

State Historical Society of North Dakota

612 E. Boulevard Avenue

Bismarck, North Dakota 58505

July 2008

Research Contribution No. 81

DOI: https://doi.org/10.32946/PCRG.081

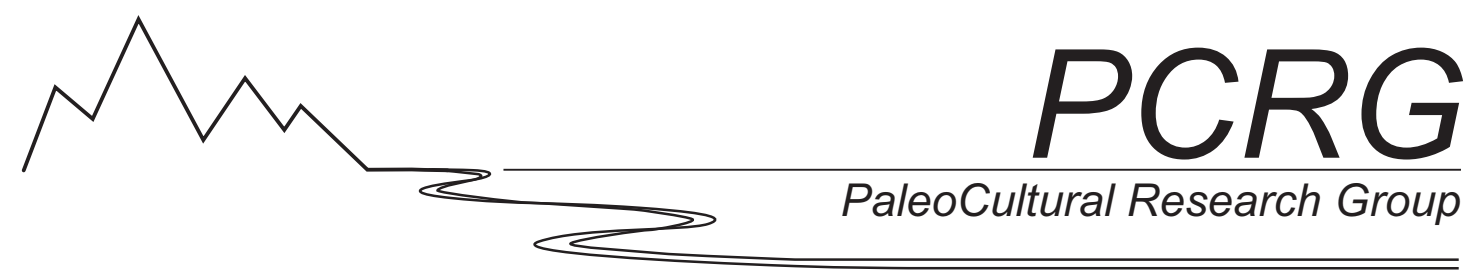


The survey and testing project at Larson Village that is the subject of this report has been financed in part with Federal funds from the National Park Service, United States Department of Interior, and administered by the State Historical Society of North Dakota. However, the contents and opinions do not necessarily reflect the views or policies of the Department of Interior or the State Historical Society of North Dakota, nor does the mention of trade names or commercial products constitute endorsement or recommendation by the Department of Interior or the State Historical Society of North Dakota.

This program receives Federal financial assistance for identification and protection of historic properties. Under Title VI of the Civil Rights Act of 1964, Section 504 of the Rehabilitation Act of 1973, and the Age Discrimination Act of 1975, as amended, the U. S. Department of the Interior prohibits discrimination on the basis of race, color, national origin, disability or age in its federally assisted programs. If you believe you have been discriminated against in any program, activity, or facility as described above, or if you desire further information, please write to:

\author{
Office of Equal Opportunity \\ National Park Service \\ 1849 C Street, N.W. \\ Washington, D. C. \\ 20240
}




\begin{abstract}
Larson Village (32BL9) is a large, fortified earthlodge settlement located on the east bank of the Missouri River about 20 km north of Bismarck, North Dakota. In 2006 and 2007, PaleoCultural Research Group (PCRG), the State Historical Society of North Dakota (SHSND) and the Archeo-Imaging Lab in the Department of Anthropology at the University of Arkansas, carried out a series of archaeological and geophysical investigations to determine when the settlement was founded, to map its major features and determine its maximum extent, and to obtain a sample of artifacts that could be compared with similar samples from contemporaneous villages in the Heart region.

The full-coverage magnetic survey revealed the presence of two previously unrecorded fortification systems arcing around the village, just beyond and beneath the outermost midden mounds, along with numerous discrete anomalies representing hearths, cache pits, and other features. Geophysical surveys also confirmed the presence of a third fortification system winding through the middle of the site. Topographic and other data documented the presence of an artificial embankment extending north, away from the northern edge of the settlement. Several lines of evidence demonstrated that the large basin adjacent to the central core of the village served as an open, public plaza throughout the village's history. Test excavation on the northern edge of the village documented the presence of a variety of features, including postholes, cache pits, and small basins, and produced a large sample of artifacts for comparative analysis.
\end{abstract}

Radiocarbon and other data suggest, but do not conclusively demonstrate, that the village was founded about 1500 . The chipped stone assemblage is dominated by smooth gray Tongue River silicified sediment and Knife River flint, with exotic stones notably rare. The ceramic assemblage is dominated by Le Beau Classic vessels, but also includes a significant number of braced straight-rim vessels bearing tool impressions. Incised shoulder decoration also is common. Several imported ceramic vessels were documented. In addition to the dominant tropical cultigens, farmers at Larson raised sunflowers and marshelder. Bison was far and away the most important source of meat, but the remains of large canids also make up a significant portion of the faunal assemblage.

The layout and occupational history of Larson are similar to those of nearby Double Ditch Village. Both communities were founded at about the same time and both contracted progressively over a period of about three centuries. Both are ringed by a series of high midden mounds that at one time may have been incorporated in their defenses. Both contain permanent open plazas. However, in other respects Larson and Double Ditch are rather different. Large-scale sediment transport appears to have been far less common at Larson. Small features and earthlodge floors or outdoor activity areas are preserved on the perimeter of Larson, but not at Double Ditch, suggesting that the outskirts of the two villages were used by later residents in rather different ways. 


\section{TABLE OF CONTENTS}

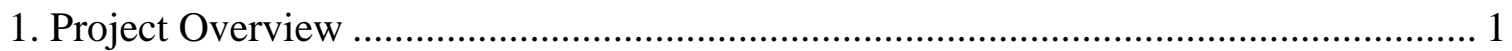

Mark D. Mitchell

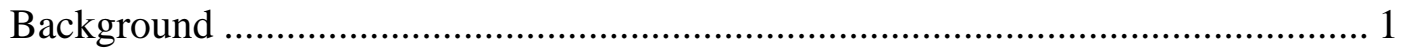

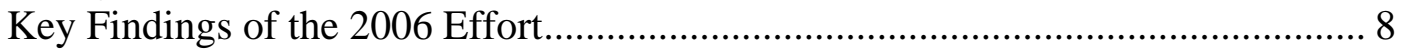

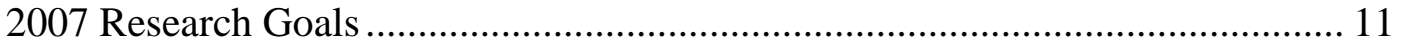

Report Contents and Major Conclusions................................................................. 12

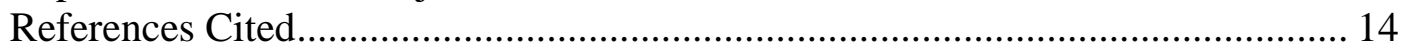

2. Geophysical Survey and Topographic Mapping.......................................................... 17

Kenneth L. Kvamme

Introduction and Study Area ............................................................................ 17

The Magnetic Gradiometry Survey and Associated Results................................... 18

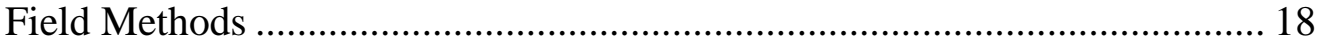

Theory and Instrumentation................................................................... 19

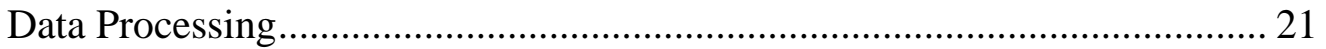

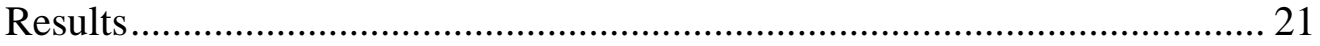

Evidence from Excavations in 2006................................................... 22

Analysis of Hearth and Pit Data by Coring Program of 2007 ......................... 24

Fortification Ditches ................................................................................. 28

Fortification Ditch Magnetism..................................................................... 32

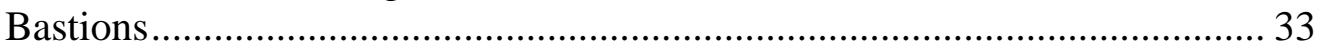

Mounded Berms ....................................................................................... 34

Mounds and Mounded Middens .................................................................. 35

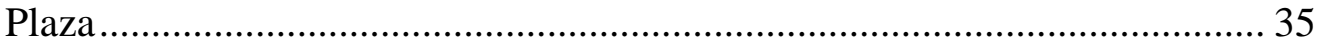

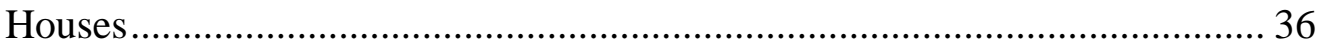

Borrow Pits ........................................................................................... 37

Magnetic Anomalies from Modern Sources ...................................................... 37

The Topographic Survey and Creation of a Digital Elevation Model .................... 40

The Robotic Total Station.............................................................................. 41

Field Methods ............................................................................................. 42

Data Pre-processing and Creation of Initial DEM......................................... 43

DEM Post-processing ........................................................................... 44

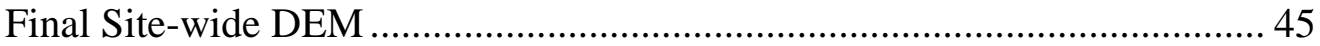

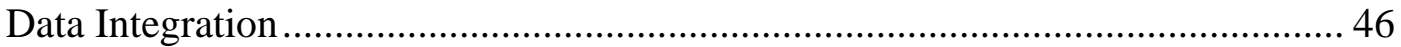

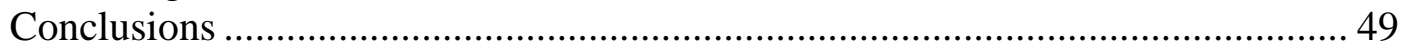

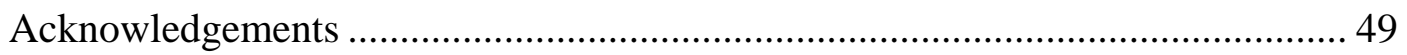

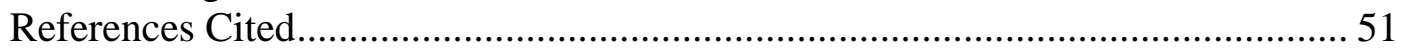

Coring Data for Hearths and Pits ........................................................................ 52

Magnetic Gradiometry and Topographic Maps ...................................................... 53

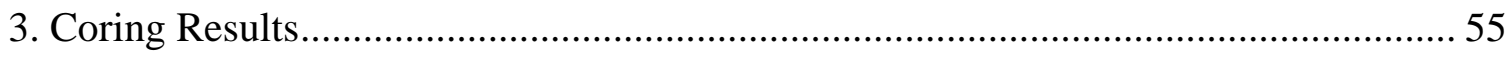

Mark D. Mitchell

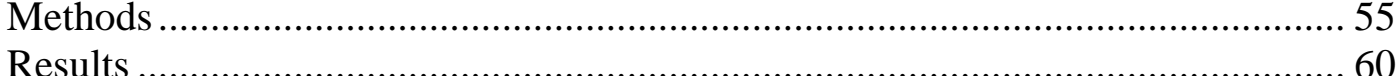


Village Periphery Studies ............................................................................... 60

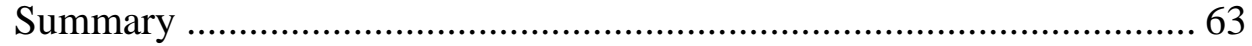

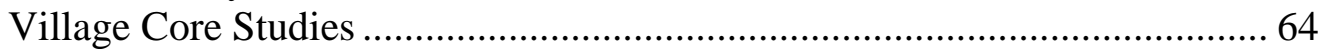

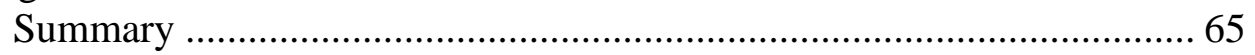

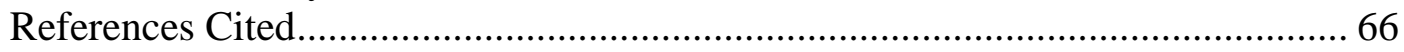

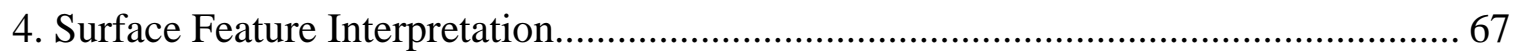

Mark D. Mitchell, Fern E. Swenson, and Paul R. Picha

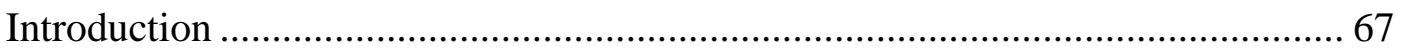

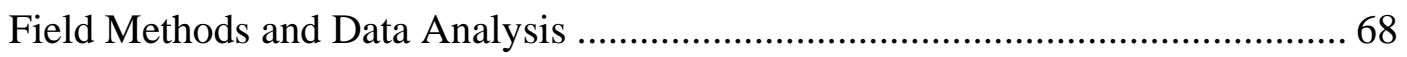

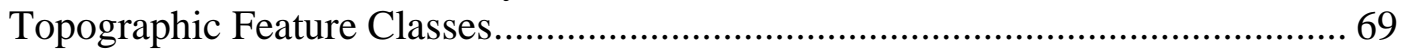

Feature Classification and Discussion............................................................. 70

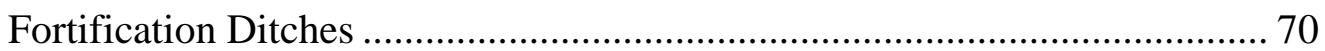

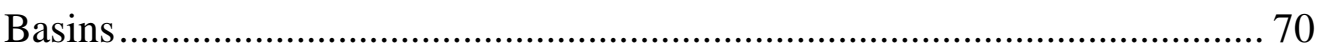

Historic Excavations and Potholes............................................................. 74

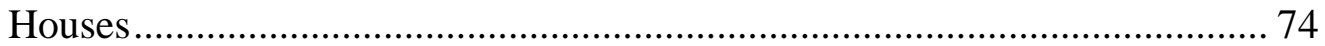

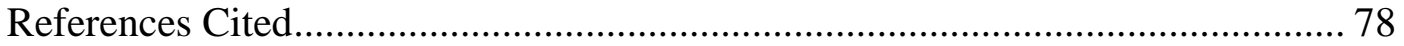

5. Inventory and Analysis of Existing Collections ………………................................... 79

Mark D. Mitchell and Fern E. Swenson

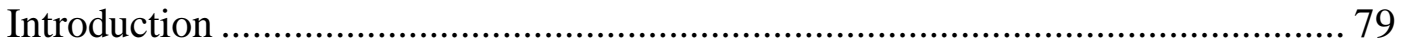

Logan Museum of Anthropology Collection ...................................................... 79

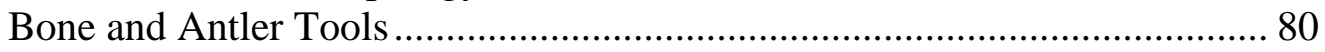

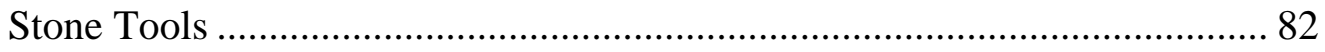

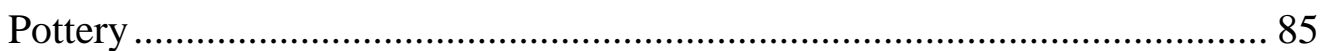

State Historical Society of North Dakota Collection .............................................. 88

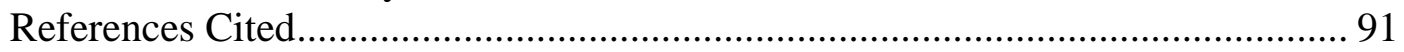

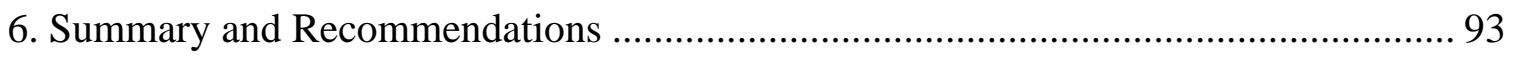

Mark D. Mitchell

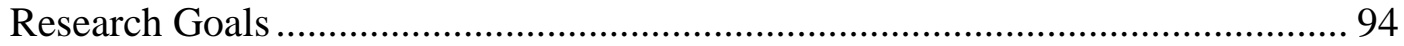

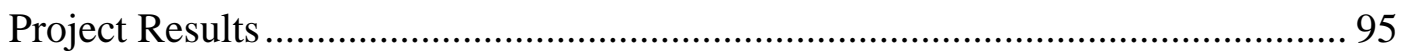

Major Features ........................................................................................ 95

Extent and Condition of Cultural Deposits.................................................. 97

Formation Processes ................................................................................. 98

Chronology and Settlement History............................................................. 98

Material Comparisons .................................................................................. 99

Comparisons to Double Ditch Village ………………......................................... 100

Recommendations for Future Work ............................................................... 101

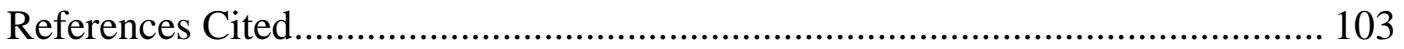




\section{LIST OF TABLES}

Table 2.1. Mean apparent magnetism and pit depth by site region. .............................. 27

Table 2.2. Hearth data from PCRG coring program. ..................................................... 52

Table 2.3. Pit data from PCRG coring program. ..................................................... 52

Table 3.1. Coring data, 2007 PCRG field investigations at Larson Village..................... 56 Table 3.2. Coring data on eight hearth features identified during the 2007 PCRG field

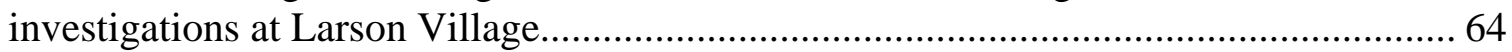

Table 4.1. Data on houses and possible houses, 2007 PCRG field investigations at Larson

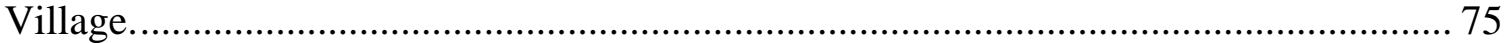

Table 5.1. Inventory of modified bone and antler artifacts from Larson Village held by the Logan Museum of Anthropology....

Table 5.2. Inventory of stone tools from Larson Village held by the Logan Museum of

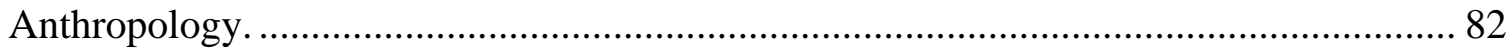

Table 5.3. Stone tool technological classes organized by raw material type................... 83 Table 5.4. Comparison of rim form frequencies in the Logan Museum and 2006 PCRG samples from Larson Village. 85

Table 5.5. Comparison of ware frequencies in the Logan Museum and 2006 PCRG samples from Larson Village.

Table 5.6. Comparison of Le Beau ware varieties in the Logan Museum and 2006 PCRG samples from Larson Village. 86 Table 5.7. Comparison of decorative techniques used on Knife River ware vessels in the Logan Museum and 2006 PCRG samples from Larson Village. 87 Table 5.8. List of small artifact collections from Larson Village held by the SHSND.... 88 Table 5.9. List of artifacts from Larson Village in the Ralph Thompson Collection....... 89 Table 5.10. List of miscellaneous artifact collections from Larson Village held by the SHSND. 89 


\section{LIST OF FIGURES}

Figure 1.1. Map of the Heart River region, showing the location of Larson Village and

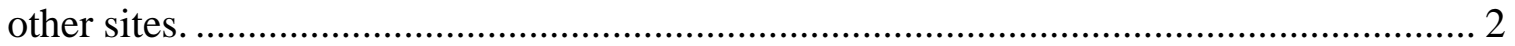

Figure 1.2. Overview of the 2006 testing program....................................................... 3

Figure 1.3. Aerial photograph showing the boundary of Larson Village.......................... 4

Figure 1.4. Ditch 1 at Larson Village. View to the south. ................................................ 5

Figure 1.5. Historic plan maps of Larson Village........................................................... 6

Figure 1.6. Alfred W. Bowers in Work D at Larson Village, 1929................................. 7

Figure 1.7. Bulldozer cut through Larson Village, 1975.............................................. 7

Figure 1.8. Calibrated radiocarbon date distribution of six-sample weighted mean, 2006

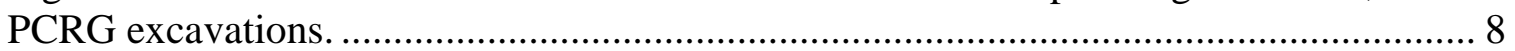

Figure 1.9. Depth of cultural deposits on a transect through the central plaza................... 9

Figure 1.10. The plaza at Larson Village................................................................. 9

Figure 1.11. Plan and profile drawings of Block D, 2006 PCRG excavations................. 10

Figure 2.1. Aerial view of the Larson site. .................................................................. 18

Figure 2.2. Instrumentation utilized for the magnetic gradiometry survey at Larson. ..... 20

Figure 2.3. The magnetic gradiometry survey at Larson showing a) the basic data without

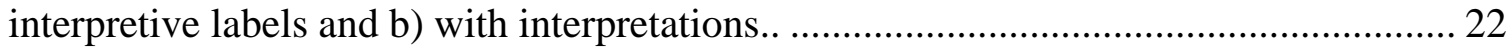

Figure 2.4. Excavations of features associated with anomalies at Larson in 2006: a) location map, b) post hole (right) and undercut pit (left) in Block A, c) post hole in Block D, d) undercut storage pit in Block F, e) Ditch 3, f) Ditch 4 ....................................... 23 Figure 2.5. Magnetic anomalies cored at Larson Village identified as hearths, hearths

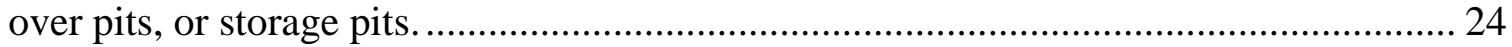

Figure 2.6. Graphs and apparent magnetism statistics for the two types of hearths at

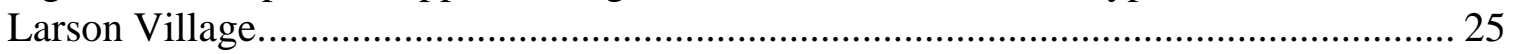

Figure 2.7. Graph of apparent magnetism (in nT) by pit depth in centimeters showing a

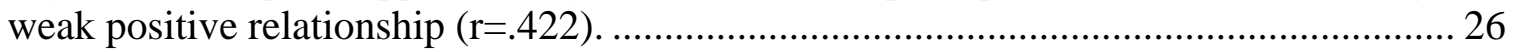

Figure 2.8. Histograms and box plots (left) and data plots with distribution diamonds (right) for the magnetic data by location..... 27

Figure 2.9. Comparison of magnetism between hearths, all storage pits, and core area

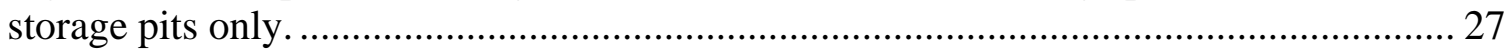

Figure 2.10. Contrast enhanced aerial photographs from (a) 1938 and (b) 1950, with

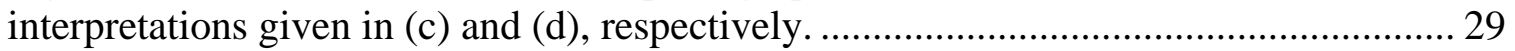
Figure 2.11. Evidence of fortification Ditches 1-2 in magnetic gradiometry results south of the county road. A) Raw data. B) Interpretations................................................... 30 Figure 2.12. Evidence for the location of Ditch 2 with interpretations. a) Aerial photography. b) Relief shaded surface. c) Magnetic gradiometry. . 31 Figure 2.13. Magnetic profiles across Fortification Ditches 1-4 showing loci of profiles (top) and graphs of magnetic variation for a) Ditch 1, b) Ditch 2, c) Ditch 3, d) Ditch 4. All graphs are profiled at the same magnetic scale from west-to-east. ........................... 32 Figure 2.14. Evidence and interpretations of bastions associated with Ditches 3-4: a) Bastion B1 and b) Bastion B3 revealed by magnetic gradiometry, and c) Bastions B2-B3 as revealed by electrical resistance survey in the 2006 geophysical survey. 
Figure 2.15. Magnetic gradiometry evidence for the Mandan central plaza 35 Figure 2.16. Dipolar anomalies resulting from iron or steel artifacts. a) Concentration of ferrous metals near historic homestead. b) A $40 \mathrm{~m}$ long lineation of dipolar anomalies produced by a buried steel wire.

Figure 2.17. Line of monopolar anomalies representing likely iron or steel artifacts by their compact form and high magnetism.

Figure 2.18. Magnetic signature of a vehicle two-track.

Figure 2.19. Large looters' holes in the surface of Larson can be a) visualized in a digital elevation model of the surface (arrows) which b) leave large dipolar anomalies owing to iron or steel artifacts within them. Figure 2.20. Likely sites of Bowers' 1929 excavations: a) Work B, b) Work D, c) Work H.

Figure 2.21. Magnetic effects of agricultural practices. a) Raw magnetic data. b) Interpretations with Ditch 4 segments and Bastion B3 (dark gray), steps/boundaries between plowed and intact prairie (light gray), and turn-around arc of chisel or disk array caused by mechanized farming (white).

Figure 2.22. The Trimble 5600 robotic total station (left), rod-mounted control pad with real-time display (middle), and wheeled reflector rod in use at Larson (right).

Figure 2.23. Data postings from the robotic total station showing transects and clustering of data points near $20 \mathrm{~m}$ collection unit boundaries, indicated by the background grid.. 43 Figure 2.24. Point thinning and TIN creation in the robotic total station data. a) Original data distribution obtained from the survey. b) Thinned distribution with all points separated by a half-meter or more. c) Delauney triangulation of a TIN model developed

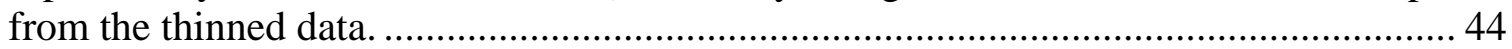
Figure 2.25. Removal of subtle striping in the DEM. a) Shaded initial DEM surface (from left) illustrating striping artifacts (circled). b) Stripes isolated by the Oimoen (2000) algorithm. c) Final DEM after subtraction of stripes (b) from the initial DEM (a). d) Statistics and histogram illustrating the low magnitude of the striping defect. .... 45 Figure 2.26. Shaded relief views of Larson surface topography computed from the DEM. a) Shading from the west. b) Shading from the northwest. c) Shading from the north. d) Principal interpretations. 46 Figure 2.27. Other representations of the Larson DEM. a, b) Three-dimensional views. c) Contour map of site segment with a $10 \mathrm{~cm}$ contour interval. 47 Figure 2.28. Enlarged close-up views of Larson's topographic surface as revealed by the DEM. a) Central village area. b) Area north of village. c) Area south of road. ............... 47 Figure 2.29. Three-dimensional magnetic overlays on the DEM. a) Site-wide view to east. b) Zoomed view to northeast showing significant relationships between magnetic

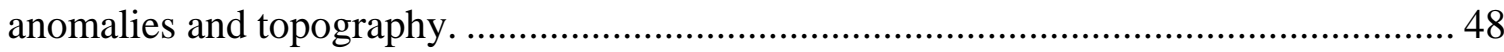
Figure 2.30. Larson Village (32BL9) magnetic gradiometry survey.............................. 53 Figure 2.31. Contour map of Larson Village (32BL9) produced from the robotic total station survey.

Figure 3.1. Map of Larson Village showing the site grid, datum locations, and

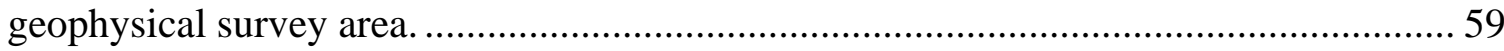

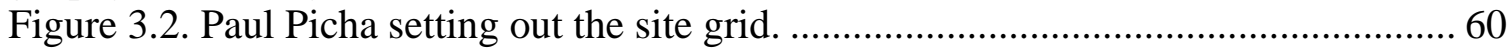

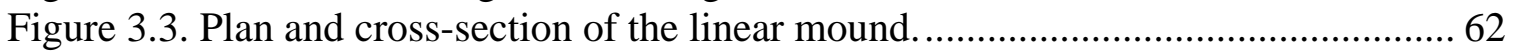


Figure 3.4. Map showing deep borrow basins at Larson Village. Shaded areas lie below $506.9 \mathrm{~m}$.

Figure 4.1. Topographic map showing the central portion of Larson Village. The areas covered by Figures 4.2 and 4.3 are indicated by dashed lines. 71 Figure 4.2. The south half of the interpreted plan map for Larson Village, overlaid onto a 10-cm interval contour map....................................................................................... 72 Figure 4.3. North half of the interpreted plan map for Larson Village, overlaid onto a 10-

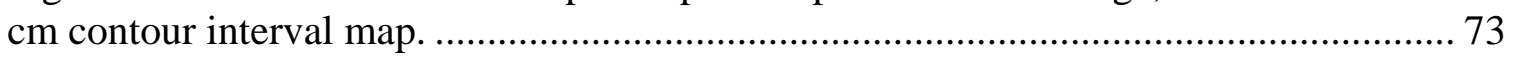
Figure 4.4. Composite interpreted plan map, Larson Village............................................. 76

Figure 5.1. Bone tools from Larson Village. left: bow-lance tip (8 cm long); right: bison

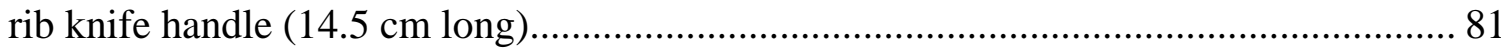
Figure 5.2. One of 13 diorite celts in the Larson Village collection at the Logan Museum (CN17093.12). 84

Figure 5.3. Selected rim sherds from the Logan Museum collection from Larson Village. a, d: imported vessels; b, c: Le Beau Recurved variety vessels. Scale varies. .................. 87

Figure 6.1. Map of Larson Village, showing the site's major features.............................. 96 


\section{ACKNOWLEDGEMENTS}

The work at Larson Village has relied greatly on the generous contributions of many PCRG members. The 2006 excavation crew included John Moret, John Vicha, Ed Maixner, Betsy Maixner, Richard Krause, Michael Krause, Janet Griffitts, Bob Gardner, Carl Falk, Laurinda Porter, Craig Johnson and Alicia Johnson. SHSND archaeologists Amy Bleier, Paul Picha, Tim Reed, and Fern Swenson each made key contributions to the success of the project. PCRG also is grateful to Paul Andahl for hosting the field crew in 2006 and again in 2007 and for allowing the research team to set up a waterscreen station on his property. Finally, PCRG thanks Larry and Joanne Spears for their interest in the site (as well as for well-timed deliveries of homemade bread), and the site's private landowners and lessee for granting permission to conduct this work. Ken Kvamme recognizes the contributions of several individuals to the success of the geophysical and topographic surveys at the end of Chapter 2.

The artifact sorting and quantification work carried out in 2006 and 2007 would not have been possible without the considerable talent and dedication of Stacey Madden. She supervised a crew of six lab assistants, including Matthew Curry, Tracy Ellefson, Michael Goldman, Mike Petriello, Michelle Qualls, and Andre Rosenzweig. Delia Moder, Kim Spurr, and Linda Maynard kept the organization running smoothly throughout the project.

Research at the Logan Museum of Anthropology at Beloit College was facilitated by Bill Green, the museum's director, and Nicolette Meister, the curator of collections. Their hospitality, and their enthusiasm for Alfred Bowers's life and career, made working at the museum a pleasure.

Over the past decade, PCRG has been privileged to work with the State Historical Society of North Dakota toward common goals. Merl Paaverud, Director of the Society, has for many years strongly supported PCRG's planning, research, and education programs. Fern Swenson, the Director of the Historic Preservation Division, has worked tenaciously to build a comprehensive understanding of culture change in the Heart River region. The Larson Village project, as well as similar work at Boley, Menoken, Double Ditch, and other sites, would not have been possible without Fern's foresight, perseverance, and thoughtful planning. 


\title{
1. Project Overview
}

\author{
Mark D. Mitchell
}

Larson Village (32BL9) is a large, fortified earthlodge settlement located on the east bank of the Missouri River, about 20 km north of Bismarck, North Dakota. For nearly 300 years, from the late 1400s until the late 1700s, Larson was one of the principal communities of the Heart region, a stretch of the Missouri River valley near its confluence with the Heart River and long home to the Mandan people (Figure 1.1). During the last decade, the native towns at Heart River have been the focus of a series of collaborative research projects carried out by PaleoCultural Research Group (PCRG), the State Historical Society of North Dakota (SHSND), and the Archeo-Imaging Lab in the Department of Anthropology at the University of Arkansas. Combining state-of-the-art geophysical surveys with problem-oriented test excavations, this work has sought to determine when these communities were founded, to map their major features, and to understand how they changed over time. The locations of houses, fortification systems, public plazas, borrow pits, and storage features have been identified through topographic, magnetic, and resistivity surveys and though soil coring and targeted test excavation. Fine-mesh recovery methods have been used to obtain samples of artifacts and ecofacts from stratified midden deposits and rapidly filled storage pits in order to compare the material content of contemporaneous communities and to trace changes in raw material use, technology, and style over time. The research team also has pursued cultural resource management goals. Magnetic data and high-resolution digital elevation models have been used to more accurately determine the boundaries of these unique and important sites and to document their current condition.

Fieldwork began at Larson Village in 2006, when the team carried out magnetic gradiometry and electrical resistivity surveys covering about 1.5 ha and opened up six small test units (Figure 1.2) (Mitchell, ed. 2007). In 2007, a small crew returned to the site to complete the magnetic gradiometry survey. The team also used a mixture of high- and low-tech methods to map the site and investigate selected subsurface features. A robotic total station was used to create a digital elevation model (DEM) of the entire site. This map brings to life a variety of subtle surface features and provides new insights into the layout and condition of the site. Oakfield soil probes also were used to explore selected magnetic anomalies in the center and on the periphery of the village. The main goals of the 2007 investigation were to learn more about the structure and extent of the settlement and to answer several specific questions that came up during analysis of the 2006 data.

The 2007 work at Larson was conducted under the terms of a cooperative agreement between PCRG and the SHSND. Both organizations are grateful to the site's private landowners and leaseholder for granting permission to conduct this investigation.

\section{Background}

When European traders and explorers first visited the Heart River region, the Mandans were organized into four bands or divisions speaking three dialects (Bowers 1948, 1950; Wood and Irwin 2001). Each division occupied one or more settlements. The largest of the four, the Nuweta or 


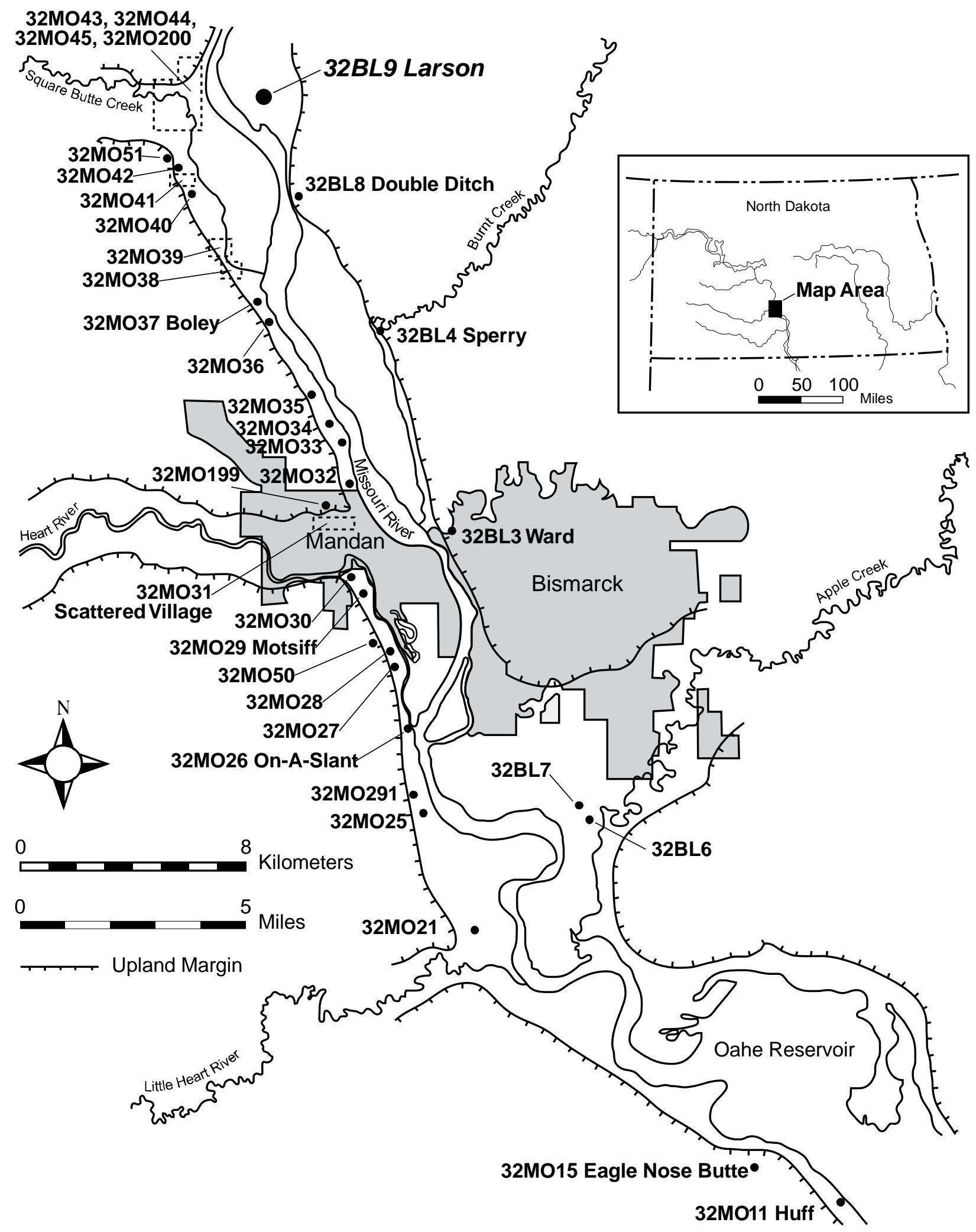

Figure 1.1. Map of the Heart River region, showing the location of Larson Village and other sites.

Nuitadi, occupied towns on the west bank of the Missouri close to the mouth of the Heart, including On-A-Slant Village. A second Nuweta-speaking division, the Istopa or "Those Who Tattoo 


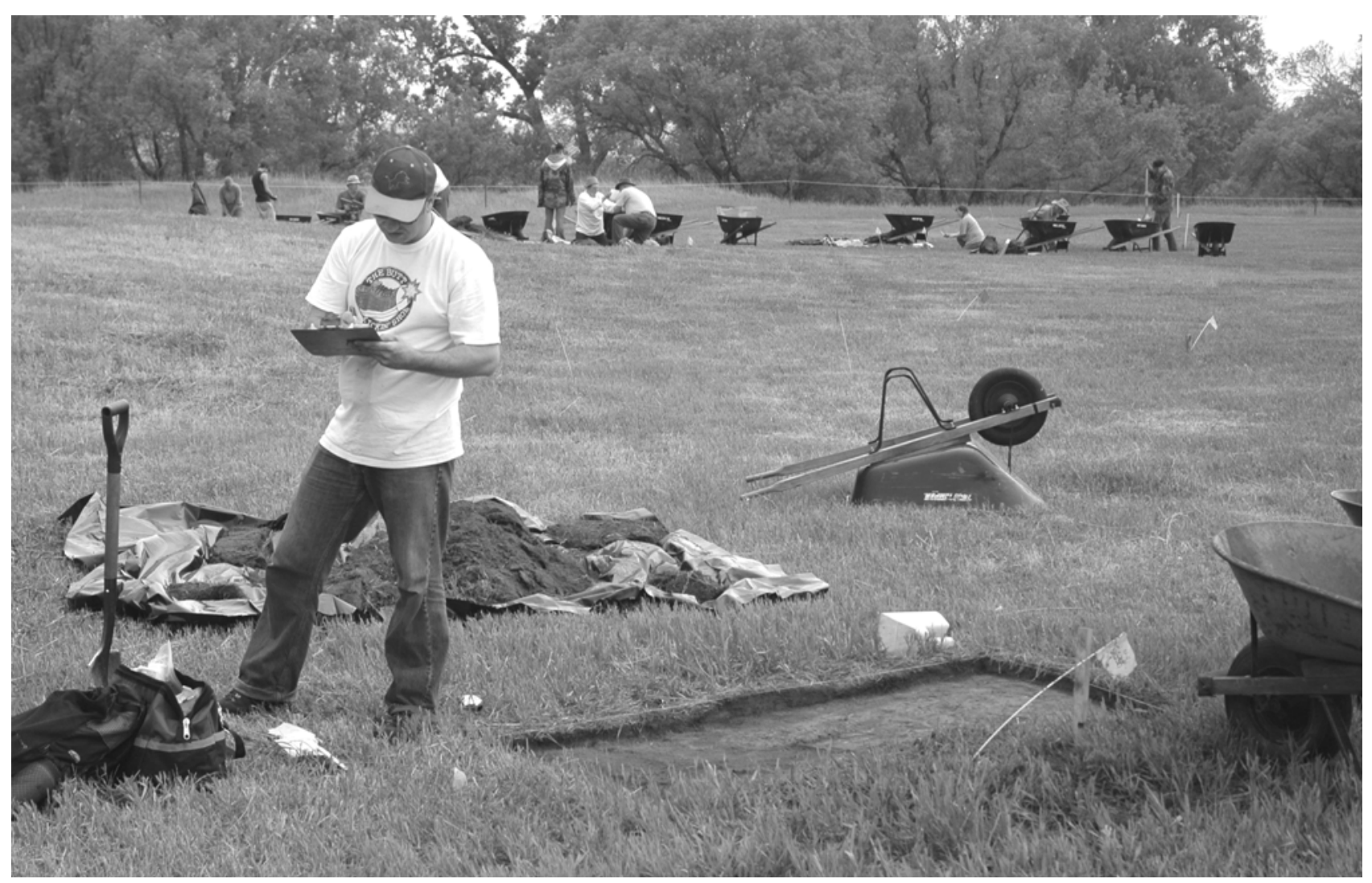

Figure 1.2. Overview of the 2006 testing program. Tim Reed in the foreground; view to the northwest.

Themselves,” also lived on the west bank, north of the Heart (Bowers 1950:25). During the eighteenth century the Istopa were joined by a third division, the Awigaxa, who until then had been living near the mouth of the Grand River in present-day South Dakota. The Awigaxa were the smallest division and spoke a distinct dialect. They were incorporated into the Nuweta after smallpox struck the Heart region in 1781. Finally, the Ruptare or Nuptadi division occupied settlements on the east bank of the Missouri. In the latter part of the eighteenth century they were divided into at least two communities: Yellow Bank Village and Round Lodge Village. Crows Heart, Alfred Bowers's principal Mandan informant, identified the Larson site as the location of Round Lodge Village (Bowers 1940). Several sources associate Double Ditch State Historic Site, located about $5 \mathrm{~km}$ south of Larson, with Yellow Bank Village (Bowers 1940, 1950; Swenson and Picha 2003; Thiessen et al. 1979).

The Larson site is located on the western edge of a broad, gently sloping fill terrace, some $10 \mathrm{~m}$ above the floodplain of the Missouri (Figure 1.3). The site currently covers about 5.1 ha (12.7 ac), but undoubtedly was larger at one time, judging by the presence of partially eroded lodge depressions lining the steep cutbank marking the western edge of the site. On the surface, the northern and eastern limits of the site are defined by a series of curvilinear midden mounds as much as $3 \mathrm{~m}$ high. Subsurface data indicate that the site actually extends at least $60 \mathrm{~m}$ beyond these mounds. The center of the village is surrounded by a well-defined fortification ditch up to $1.5 \mathrm{~m}$ deep. Earthlodge depressions within the village core are well defined, while those outside the village core are comparatively muted and amorphous. A broad, deep depression immediately north 


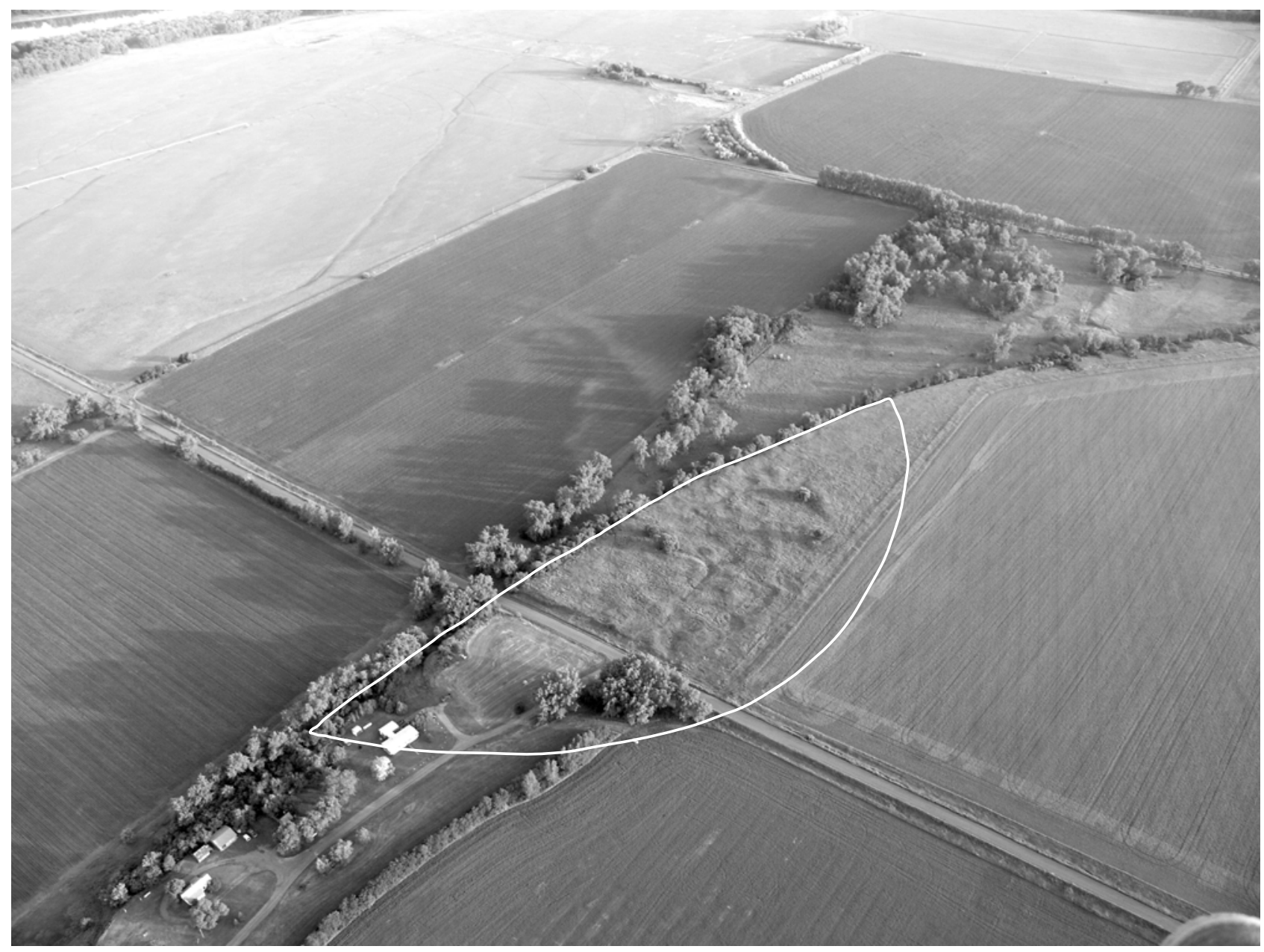

Figure 1.3. Aerial photograph showing the boundary of Larson Village. Photo taken in 2004 by Tommy Ike Hailey; view to the northwest. Note the main channel of the Missouri in the extreme upper left corner.

of the inner ditch marks the location of the community's central plaza. Beyond the plaza, to the north and east, a second fortification system, designated Ditch 2, is intermittently visible.

Different parts of the site have been affected by post-abandonment disturbances to different degrees (Swenson 2007a). Historical accounts and excavation data indicate that the northernmost section of the site has been plowed; however, the surface topography there does not seem to have been altered dramatically. By contrast, mounds and depressions on the eastern rim of the site have been completely obliterated by plowing. A county road $\left(149^{\text {th }}\right.$ Street), built in 1975 , cuts across the southern third of the site. South of $149^{\text {th }}$ Street, the site has been severely impacted by farming and by the construction of a road and several buildings.

Larson Village first received archaeological attention more than a century ago (Swenson 2007a, b). In 1904, E. R. Steinbrueck visited the site and observed two fortification ditches in the cutbank. He reported that, on the north, the outer ditch was located approximately 510 feet north of the inner ditch, just beyond the northernmost midden mounds, but on the south the two ditches only appeared to be about 100 feet apart (Steinbrueck 1904:150-151). There is no doubt that Steinbrueck's inner ditch corresponds with what is now designated Ditch 1 (Figure 1.4), but because his outer ditch is not shown on any of the early maps its track through or around the site 
was not known. Magnetic gradiometry surveys carried out during this project, along with other data, suggest that on the north Steinbrueck's outer ditch corresponds to the settlement's earliest fortification, a feature now known as Ditch 4. However, on the south, Steinbrueck's outer ditch likely corresponds to Ditch 2.

The site was first mapped the following year by George F. Will and Herbert J. Spinden, two Harvard undergraduates who were then working at nearby Double Ditch Village (Figure 1.5). They describe a "well-marked ditch," an open plaza, and a series of large mounds ringing the settlement (Will and Spinden 1906:149, Map III). They also comment on the seemingly unusual position of the fortification (the inner ditch observed by Steinbrueck), which they thought bisected rather than surrounded the site. Will and Spinden were careful surveyors, and their map of the village is remarkably accurate and precise. However, they appear not to have collected artifacts from the site.

In 1929, Alfred W. Bowers, working for the Logan Museum of Anthropology at Beloit College, mapped the village and carried out a substantial excavation program (Figure 1.5). Like Will and Spinden, Bowers (1940:36, 48) describes a single ditch, an open plaza, and a "virtual wall" of encircling midden mounds. Bowers counted as many as 77 earthlodge depressions, including six or seven on the east side of the site that nearly had been obliterated by plowing. Twenty-four depressions were noted inside

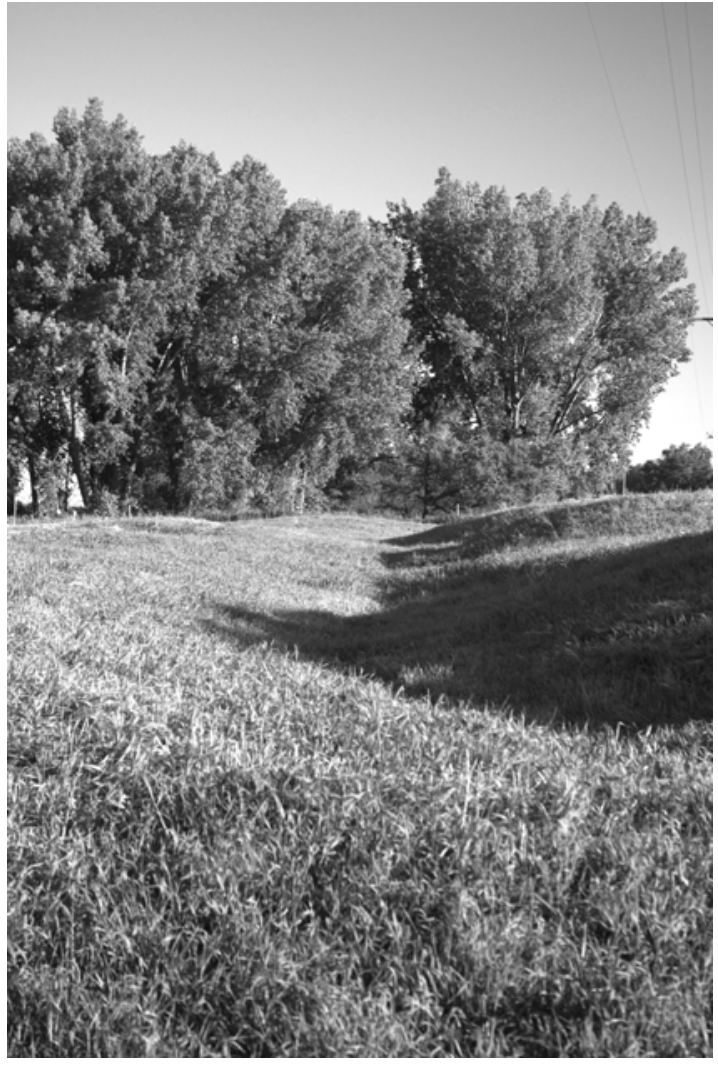

Figure 1.4. Ditch 1 at Larson Village. View to the south. the fortification ditch. Bowers excavated portions of two lodges, two large middens, and three "interlodge" areas, locating numerous features and documenting thick trash deposits between and beneath the lodges (Figure 1.6). He also demonstrated that the visible fortification system was built after the village had been occupied for some time.

Limited excavations were conducted in 1938 and 1940 by Thad Hecker. No notes describing his field methods or maps showing the locations of his excavation units are available, but at least some of the work focused on the southwestern side of the site, where a road was being cut from the terrace surface down to the floodplain (Will and Hecker 1944:23-24). Portions of a lodge floor were uncovered, along with nine large cache pits. Artifacts recovered during this work have not been analyzed.

Finally, in 1975, salvage excavations were conducted by SHSND staff during the construction of $149^{\text {th }}$ Street (Figure 1.7). Six units were opened, four in lodge depressions, one in Ditch 1, and one in a midden mound. Pottery from these excavations, which largely appear to have sampled the most recent deposits at the site, includes many large vessels with coarse decoration. 

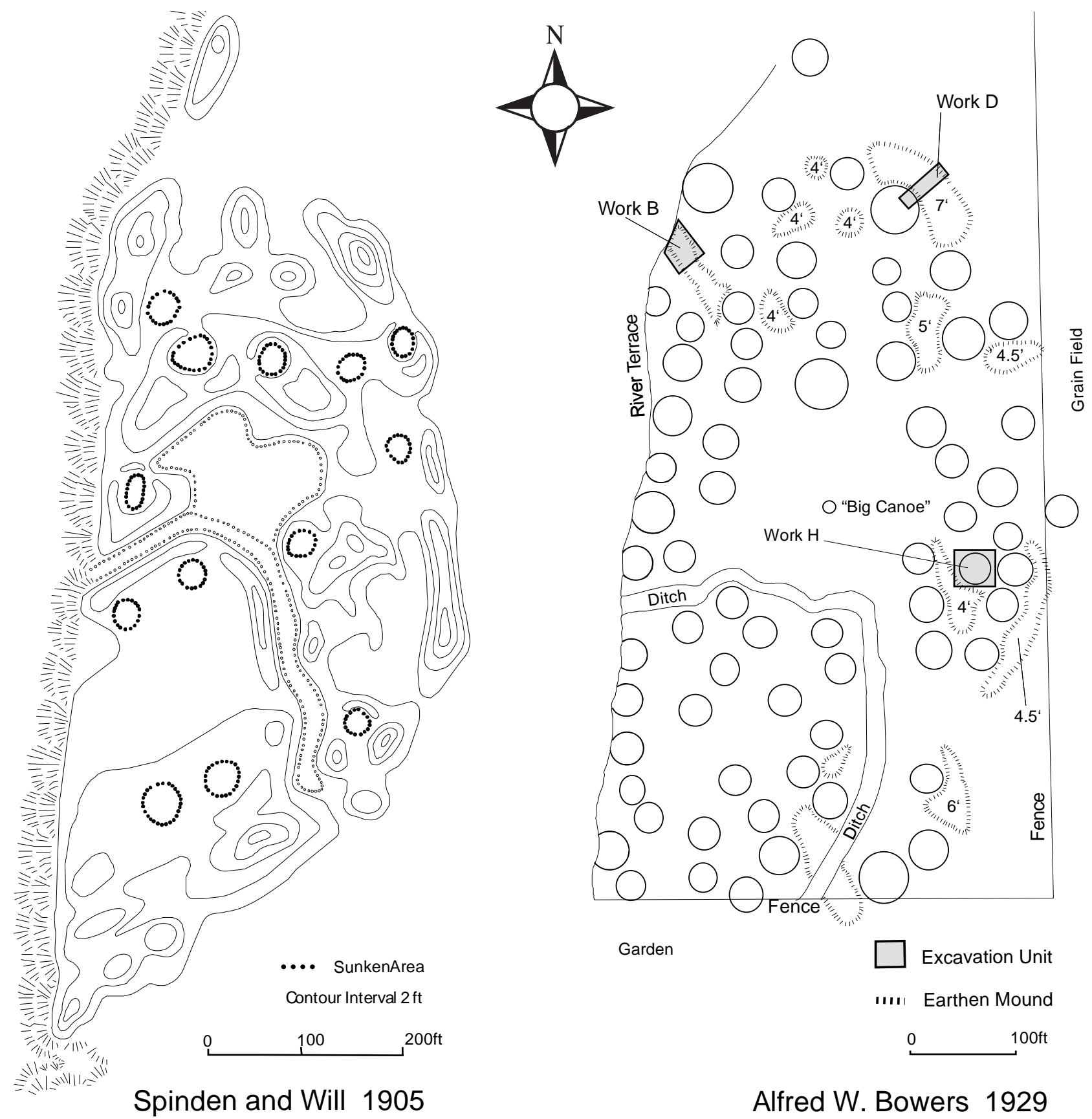

Alfred W. Bowers 1929

Figure 1.5. Historic plan maps of Larson Village. The Spinden and Will map originally was published in Will and Spinden (1906:Map III). The Bowers map has been redrafted from his original field map.

Ahler (2001:18) considers this assemblage to be distinct from contemporaneous Heart region assemblages and similar to those from the Lower Hidatsa and Big Hidatsa sites in the Knife region.

Unlike many of the other major Heart River towns, Larson Village does not appear on nineteenth and early twentieth century maps of the region. It is conspicuously absent from a map commissioned in 1906 and 1907 by Orin G. Libby, then secretary of the SHSND and professor of history at the University of North Dakota. The map, drawn by a Mandan named Sitting Rabbit, 


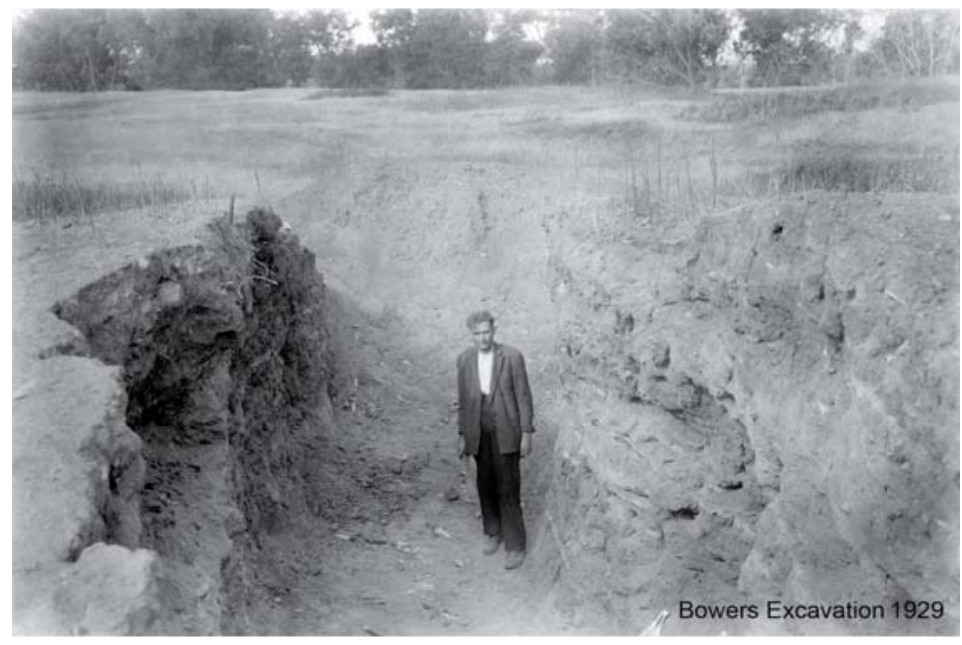

Figure 1.6. Alfred W. Bowers in Work D at Larson Village, 1929. View to the southwest.

shows the locations of numerous earthlodge villages as well as culturally significant natural features located along the Missouri River, from the South Dakota border to the mouth of the Yellowstone (Thiessen et al. 1979). Larson is not shown on a rough sketch map of village locations drawn for Gilbert Wilson by the Mandan Wounded Face (Gilbert Wilson Collection, American Museum of Natural History). Similarly, Lewis's and Clark's detailed maps do not show the site, even though the Corps of Discovery camped nearby on the night of October 22, 1804. However, it does appear on a map printed by the Missouri River Commission in 1894, labeled "Indian Mound.”

Currently, the Missouri is located more than $1.5 \mathrm{~km}$ to the west, on the far western edge of its floodplain. It is tempting to think that Larson was omitted from these maps because its distance from the river made it difficult to see. However, in 1804 the river was much closer to the village than it is today (Plamondon 2000). In fact, Will and Hecker (1944:50) report that Larson was abandoned because the river was cutting into the terrace. However, while it is clear that some portion of the site has been lost to bank erosion the specific source of Will and Hecker's information is not known. In any case, these cartographic omissions may signal that Larson was less well known to nineteenth and twentieth century Mandans than many of the other Heart region towns and therefore that it had been abandoned well before the 1781 epidemic (see also Bowers 1948:Footnote 141).

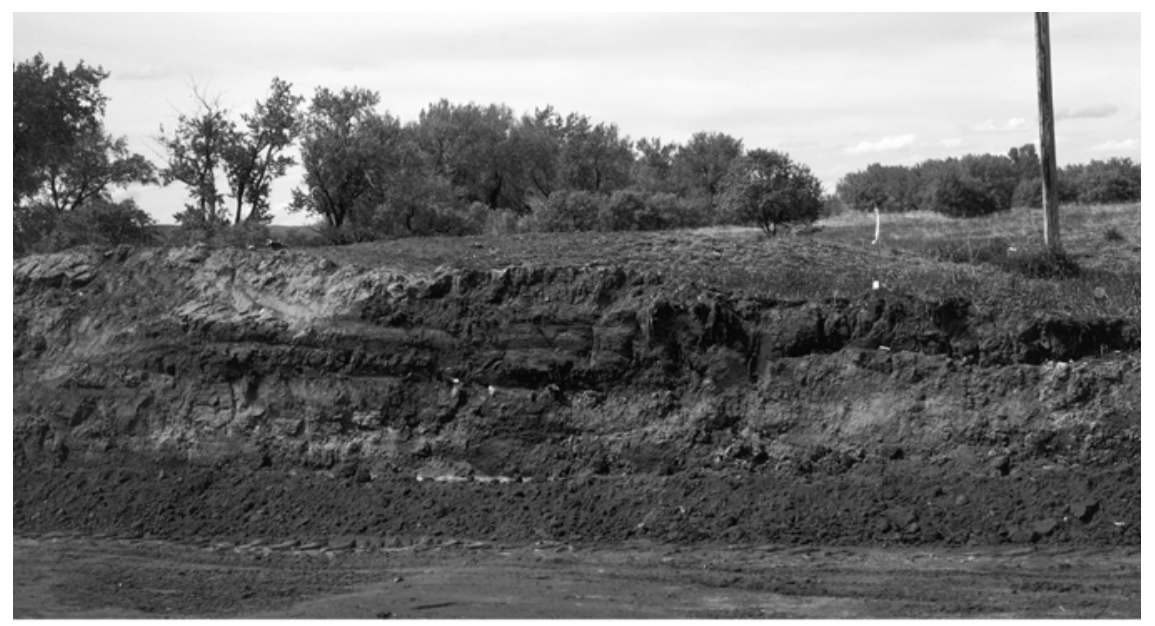

Figure 1.7. Bulldozer cut through Larson Village, 1975. View to the north. 


\section{Key Findings of the 2006 Effort}

The geophysical surveys and test excavations carried out in 2006 produced a wealth of new information about the site. Perhaps the most dramatic results relate to the number and form of the settlement's fortification systems. The magnetic map reveals the presence of two previouslyundocumented ditches arcing around the northern and eastern margins of the village, beyond the outer ring of large midden mounds. The outermost, designated Ditch 4, definitely incorporates projecting bastions similar in size and form to those found in the earliest fortification at Double Ditch Village. Ditch 3, which closely parallels Ditch 4, likely incorporates bastions as well. Stratigraphic data indicate that Ditch 4 was filled intentionally, probably over a short period of time, while Ditch 3 filled more slowly, mainly through natural sediment accumulation. Numerous magnetic anomalies thought to represent the locations of storage pits and hearths are located inside Ditch 3, while a smaller number are located between Ditch 3 and Ditch 4. Only a few are located outside Ditch 4.

Larson probably was founded in the late 1400 s or early 1500 s. Radiocarbon assays demonstrate that it must have been established before 1650: a calibrated distribution derived from six statistically contemporaneous dates spans two discrete periods: 1460 to 1530 and 1550 to 1630 (Figure 1.8). These data are corroborated by the absence from feature and stratified midden contexts of ceramic types manufactured after 1650. A small number of cuprous artifacts were recovered from stratified contexts, but iron artifacts and glass beads were absent. The provenance of the cuprous artifacts has not been determined; however, it is possible that some or all of them may have been made from native copper and therefore may well have been deposited before 1600 . The make up of the pottery assemblage and the presence of large, well-defined bastions in the settlement's earliest defensive system further support a late fifteenth or early sixteenth century founding date. Using similar evidence, Ahler (2005) has argued that Double Ditch was established at about that time.

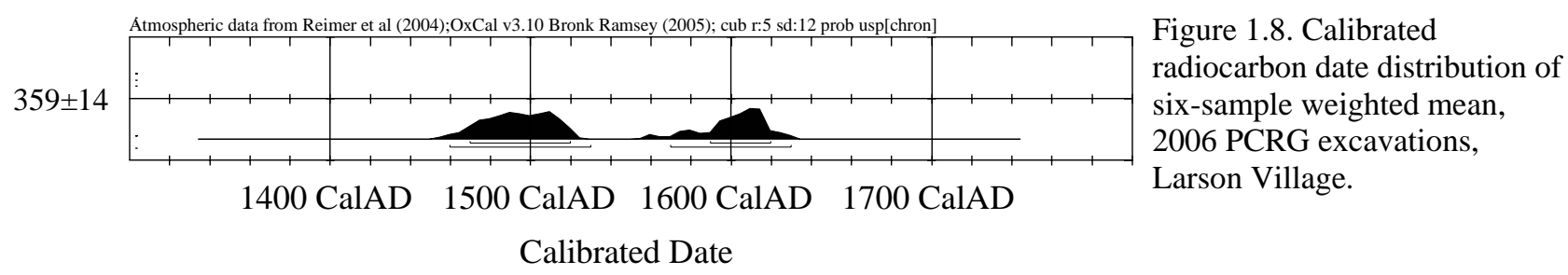

Data from the 2006 field effort, combined with evidence obtained by Alfred Bowers, indicates that Larson contracted progressively over time. Ditch 4 probably was built when the village was founded, while Ditch 1 clearly is the most recent. In this respect, Larson's occupation history closely parallels that of Double Ditch. Over time, both villages diminished in size and, presumably, in population. However, the ages of Ditch 1 and Ditch 2 at Larson are not known. For this reason, it is uncertain whether the two villages contracted synchronously. As noted above, it is possible that Larson was abandoned earlier than Double Ditch.

Geophysical data and hand coring demonstrate that the large, flat-bottomed basin immediately north of the village core represents the town's plaza. Pit features and other cultural deposits are absent from the floor of the basin (Figures 1.9 and 1.10). In addition, a substantial amount of sediment has been removed from this part of the site, suggesting that the basin served 


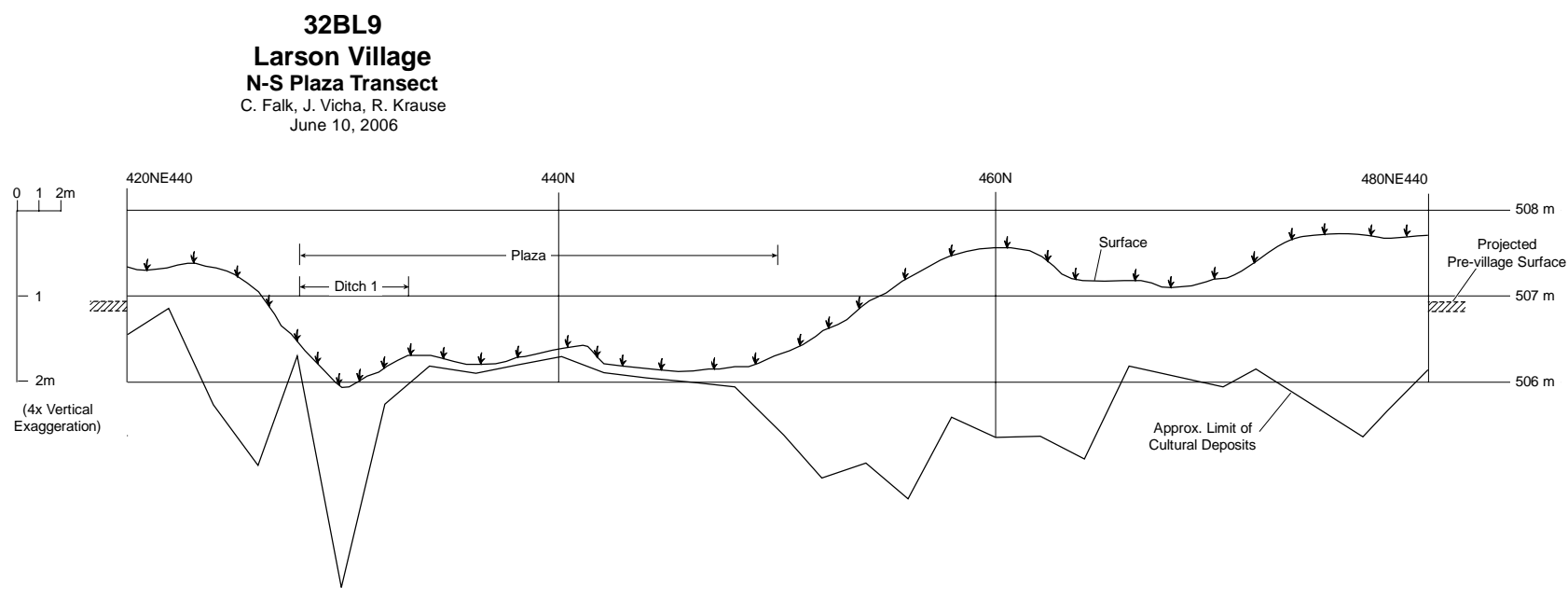

Figure 1.9. Depth of cultural deposits on a north-south transect through the central plaza.

both as an open, public space and as a source of clean sediment for the construction and maintenance of earthlodges. The absence of storage pits and sheet midden deposits further suggests that the basin was used as a plaza throughout the history of the settlement, even after the residents withdrew inside Ditch 1.

Excavation on Larson's northern perimeter exposed a variety of small features, including postholes and small basins, along with intervening surfaces (Figure 1.11). The presence of these features indicates that portions of earthlodge floors or outdoor activity areas may be preserved in this part of the site. By contrast, such surfaces and features have been removed from the perimeter of Double Ditch. There, both cultural features and natural soil horizons have been churned to a depth of 50 to $80 \mathrm{~cm}$. The processes responsible for this obliteration are not known, but it may have been caused in part by the construction and use of near-village gardens. The apparent absence of such homogenized deposits at Larson suggests that the outskirts of the two villages were used in

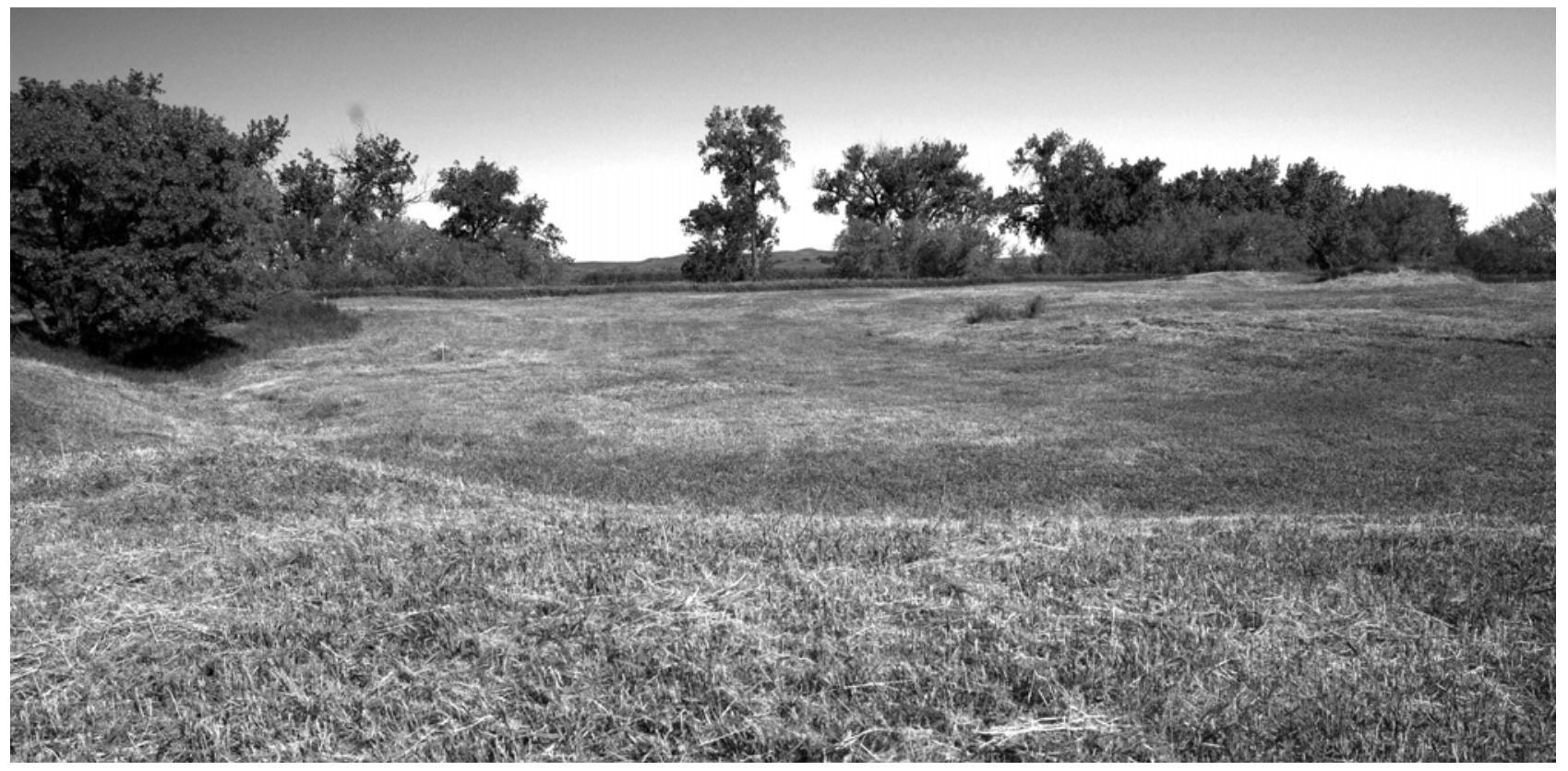

Figure 1.10. The plaza at Larson Village. View to the west. 


\section{different ways.}

Hand coring along a north-south transect between Ditch 1 and Ditch 2 at Larson suggests that cultural deposits there accumulated progressively over time (Figure 1.9). By contrast, at Double Ditch, debris and sediment inside Ditch 2 were periodically removed and transported to the mounds surrounding the site. This "planar borrowing," therefore, may have been tied to the construction of the village's defensive works, which at various times seem to have incorporated mounds. The removal of accumulated materials may also have been part of a process of community renewal. The comparative absence of similar sediment borrowing and transport at Larson could indicate that rather different processes were responsible for the formation of its superficially similar mounds.

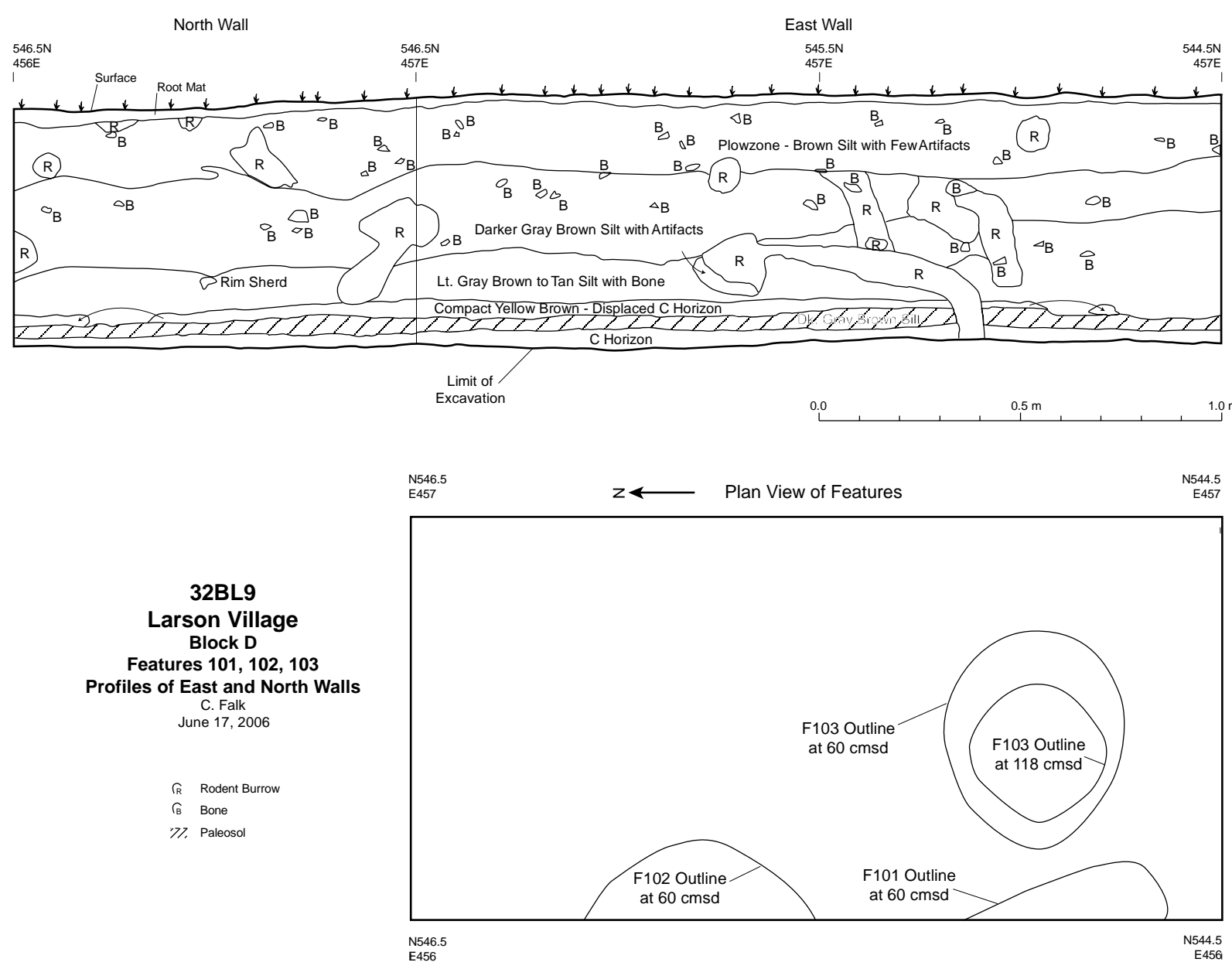

Figure 1.11. Plan and profile drawings of Block D, 2006 PCRG excavations. Note layer of displaced C-horizon sediment overlying the intact humic layer.

The pottery and stone tool assemblages recovered from Larson are similar to Time Period 4 (1490-1600) assemblages at Double Ditch. At both villages the ceramic sample is dominated by Le Beau Classic variety rims. Transitional ware, and Le Beau Sperry and Plain varieties, are all but absent. Unclassified rims are common in both, as are decorated body sherds. Flintknappers at both villages made extensive used of smooth gray Tongue River silicified sediment for the production of stone tools. Data from Double Ditch suggests that this material was brought to the village in the 
form of large flakes or cores and was preferentially used for making unpatterned flake tools. By contrast, Knife River flint was brought to the village in the form of small cobbles, tool preforms, or finished tools, and was used most often for making patterned tools, including arrowpoints, knives, and end scrapers. Similar technological patterns are evident in the contemporaneous chipped stone assemblage from Larson.

\section{Research Goals}

These findings answered a number of important questions about the site, but they also raised several new questions, which the research team believed could be answered through non-destructive methods, including hand coring and geophysical surveys. Four principal research domains were identified for the 2007 fieldwork, domains that reflect the overall goals of the project, as well as the specific results of the initial field season.

- Village Size: Magnetic gradiometer surveys conducted at Double Ditch and at Huff villages indicate that features seldom were constructed outside the village fortification. The seeming presence of several large anomalies outside Ditch 4 at Larson could therefore signal that the village was in fact larger than the team initially believed. This possibility was reinforced by the discovery during data processing of a faint linear anomaly, informally dubbed "Ditch 5," running parallel to, but outside, Ditch 4. Accordingly, one of the aims of the 2007 effort was to determine whether cultural features were present north and east of Ditch 4 and specifically whether the "Ditch 5" anomaly indeed represented another fortification system. At the same time, little was known about the southern limits of the site. Historic photographs clearly show that village features were present well south of what is now $149^{\text {th }}$ Street, but no data were available to indicate how far south the site extended. Hand coring was used to investigate selected features on the periphery of the village.

- Subsurface Condition: Surface data and historical records clearly indicate that portions of the site have been disturbed by plowing, construction, and unprofessional excavation. However, the maximum extent and overall condition of buried cultural deposits was not known. In particular, the research team wanted to know whether intact cultural features were present south of $149^{\text {th }}$ Street. The team also wanted to create a permanent record of the site's current condition, which can be used for future management and research activities. The magnetic gradiometry survey was used to map the distribution of subsurface features.

- Settlement Layout: Because the 2006 field investigation focused mainly on the northern and eastern edges of the site, several important questions remained about the overall layout of the village. Specifically, little was known about the track of Ditch 2 through the middle of the village; only about half of the central plaza had been surveyed; and nothing was known about the size or distribution of magnetic anomalies inside Ditch 1. A combination of methods was used to fill in the map of the settlement's major features, including topographic and magnetic surveys and hand coring.

- Feature Interpretation: Recent work at Double Ditch has demonstrated that many of the topographic depressions once thought to mark the former locations of earthlodges in fact represent borrow basins or other features. For this reason, a central goal of the 2007 fieldwork was to differentiate house depressions from borrow basins. Guided by the preliminary magnetic data, the team cored selected magnetic anomalies located inside Ditch 2. The results of the coring program were then combined with topographic attributes to 
make functional interpretations of each depression. In the lab, these initial determinations were adjusted and refined using the site DEM and the complete magnetic survey. The feature coring data also were used to compare the magnetic signatures of hearths with those of storage pits in an effort to differentiate them by their geophysical characteristics.

To round out the project, preliminary analyses of stone tools and pottery vessels collected by Alfred Bowers also were undertaken. The goals of this work were to supplement conclusions drawn from analyses of artifacts recovered during the 2006 testing program and to encourage further study of existing collections.

\section{Report Contents and Major Conclusions}

Chapter 2 of this report, written by Kenneth L. Kvamme, discusses the geophysical and topographic surveys. Instrumentation and field methods, as well as data processing techniques, are described. The results of these surveys are presented along with analyses of selected aspects of the data. With completion of this work, Larson joins a growing list of northern Plains settlements for which full-coverage magnetic maps are available. This work also demonstrates the value of combining magnetic data with high-resolution topographic data.

Results of the hand coring work are presented in Chapter 3. The presentation is divided into three sections. The first provides an overview of the field work and the methods used. The second discusses coring data obtained on various anomalies on the periphery of the village, while the third discusses data on anomalies and other features located in the village core. On the northern edge of the site, coring data confirm the existence of substantial features outside Ditch 4, but nevertheless indicate that a fifth fortification ditch is not present. They also document a low ridge or linear mound extending northward, beyond Ditch 4, the first such feature observed in the Heart region. In the village core, eight intact hearth features were documented along with numerous debris-filled storage pits. Coring data also demonstrate that the planar borrowing so widespread at Double Ditch did not take place on a similarly large scale at Larson.

Interpretations of selected surface features located inside Ditch 2 are presented in Chapter 4. This work bolsters conclusions drawn from a similar analysis undertaken at Double Ditch. Both studies indicate that many of the depressions once thought to represent the former locations of earthlodges in fact represent borrow areas or other features. The results demonstrate that multiple lines of evidence, including magnetic, topographic, and coring data, are needed to interpret such features with confidence.

Chapter 5 summarizes and discusses data on artifacts collected by Alfred Bowers during his 1929 excavations. The pottery analysis suggests that Larson was occupied continuously from the time it was founded around 1500 until the time it was abandoned in the late 1700s. The stone tool analysis confirms the importance of smooth gray TRSS for the production of stone tools, and provides additional evidence for the presence of specialized craft producers in the Heart River towns. An inventory of artifacts from the site held by the State Historical Society of North Dakota also is presented, along with brief summaries of two recent analyses of selected portions of that collection. 
Finally, Chapter 6 combines the results of this work with the results of the 2006 field investigations and subsequent analyses and summarizes what has been learned about the site. Directions for future are also suggested. 


\section{References Cited}

Ahler, Stanley A.

2001 Analysis of Curated Plains Village Artifact Collections for the Heart, Knife, and Cannonball Regions, North Dakota. Research Contribution No. 42. PaleoCultural Research Group, Flagstaff, Arizona. Submitted to the State Historical Society of North Dakota, Bismarck.

2005 Analytic Structure and Collection Chronology. In Archaeological Investigations During 2004 at Double Ditch State Historic Site, North Dakota, edited by Stanley A. Ahler, pp. 157-180. Research Contribution No. 65. PaleoCultural Research Group, Flagstaff, Arizona. Submitted to the State Historical Society of North Dakota, Bismarck.

Bowers, Alfred W.

1940 Missouri River Earthlodge Archaeology of North Dakota and South Dakota. Ms. on file at the Logan Museum of Anthropology, Beloit College, Beloit, Wisconsin.

1948 A History of the Mandan and Hidatsa. Unpublished Ph.D. dissertation, Department of Anthropology, University of Chicago.

1950 Mandan Social and Ceremonial Organization. University of Chicago Press, Chicago. Mitchell, Mark D. (editor)

2007 Geophysical Survey and Test Excavation During 2006 at Larson Village, Burleigh County, North Dakota. Research Contribution No. 80. PaleoCultural Research Group, Flagstaff, Arizona. Submitted to the State Historical Society of North Dakota, Bismarck.

Plamondon, III, Martin

2000 Lewis and Clark Trail Maps: A Cartographic Reconstruction. Washington State University Press, Pullman.

Steinbrueck, E. R.

1904 Mandan Village Site. In Mandan Memoirs of Explorations in the Basin of Mississippi. J. F. Bower Press of McGill-Warner Co., St. Paul, Minnesota.

Swenson, Fern E.

2007a Previous Investigations at Larson Village. In Geophysical Survey and Test Excavation During 2006 at Larson Village, Burleigh County, North Dakota, edited by Mark D. Mitchell, pp. 11-25. Research Contribution No. 80. PaleoCultural Research Group, Flagstaff, Arizona. Submitted to the State Historical Society of North Dakota, Bismarck.

2007b Settlement Plans for Traditional Mandan Villages at Heart River. In Plains Village Archaeology: Bison-hunting Farmers on the Northern and Central Plains, edited by Stanley A. Ahler and Marvin Kay, pp. 239-258. University of Utah Press, Salt Lake City.

Swenson, Fern E., and Paul R. Picha

2003 History of Previous Studies. In Archaeological Investigations During 2001 and 2002 at Double Ditch State Historic Site, North Dakota, edited by Stanley A. Ahler, pp. 19-34. Research Contribution No. 56. PaleoCultural Research Group, Flagstaff, Arizona. Submitted to the State Historical Society of North Dakota, Bismarck.

Thiessen, Thomas D., W. Raymond Wood, and A. Wesley Jones

1979 The Sitting Rabbit 1907 map of the Missouri River in North Dakota. Plains Anthropologist 24(84, Part 1):145-167.

Will, George F., and Thad. C. Hecker

1944 The Upper Missouri River Valley Aboriginal Culture in North Dakota. North Dakota Historical Quarterly XI(1-2). 
Will, George F., and Herbert J. Spinden

1906 The Mandans: A Study of Their Culture, Archaeology, and Language. Papers of the Peabody Museum of American Archaeology and Ethnology 3(4):81-219.

Wood, W. Raymond and Lee Irwin

2001 Mandan. In Handbook of North American Indians: Plains, Volume 13, Part 1, edited by Raymond J. DeMallie, pp. 349-364. Smithsonian Institution, Washington, D.C. 


\title{
2. GEOPHYSICAL SURVEY AND TOPOGRAPHIC MAPPING
}

\author{
Kenneth L. Kvamme
}

\section{Introduction and Study Area}

This chapter describes the results of a magnetic gradiometry survey as well as a surface mapping project by electronic total station carried out at the Larson site (32BL9) in the summer of 2007. The gradiometry survey was undertaken to complete this survey over the entire site, which was initiated in the summer of 2006 (Kvamme 2006a). The total station survey was performed to record by digital means the nature of the ground surface at this important site, which exhibits numerous expressions of the prehistoric occupation. These investigations were performed by the Archeo-Imaging Lab, Department of Anthropology, University of Arkansas, by Kenneth L. Kvamme, Lab Director, and Duncan McKinnon, graduate student, under contract agreement with the PaleoCultural Research Group (PCRG) of Flagstaff, Arizona. Data were collected from June 26 through July 6, 2007.

The Larson site is a large, fortified, earthlodge settlement on the east bank of the Missouri River about two miles north of the Double Ditch State Historic Site and several miles north of present-day Bismarck. Natural processes and recent development has obliterated much of Larson, perhaps up to 40 percent (Swenson 2007). The site is located on the edge of a terrace that probably was situated close to the Missouri River during its occupation. The River now lies nearly a mile to the west. Prior to its westward migration, a significant western portion of the site was apparently eroded. A county road (149th Street) cuts through the village somewhat south of its center, a homestead occupies part of its southern area which dates to at least the early twentieth century, and agricultural fields have obliterated its eastern reaches through intensive plowing for more than a century. These elements are visible in an aerial photograph of the site obtained from the U.S. Geological Survey showing a 1997 view (Figure 2.1a). A grid of $20 \mathrm{~m}$ square blocks is superimposed over the aerial photograph which illustrates the extent of the magnetic gradiometry surveys. Figure $1 \mathrm{~b}$ indicates areas surveyed by magnetic gradiometry in 2006 and 2007.

The grid in Figure 2.1 also approximately encompasses the extent of the total station mapping of Larson's surface. That survey, however, was confined to the region west of the fence line and cultivated field indicated in Figure 2.1, but it also superseded the gridded area by including the area of the county road, and relatively small areas extending further north and south of the grid.

This report summarizes the complete magnetic gradiometry survey including data from both years, as well as the surface mapping by electronic total station. Additionally, data from the electrical resistance survey of 2006 are occasionally utilized to bolster analyses, as are aerial photographs. The goal of this report is to give a comprehensive assessment of significant findings learned by geophysical survey, topographic mapping, and aerial photography at Larson, 
but to not be overly redundant with the report of work conducted in 2006 (Kvamme 2006a). Consequently, detailed descriptions of the electrical resistance and electromagnetic induction surveys of that year are not repeated here.
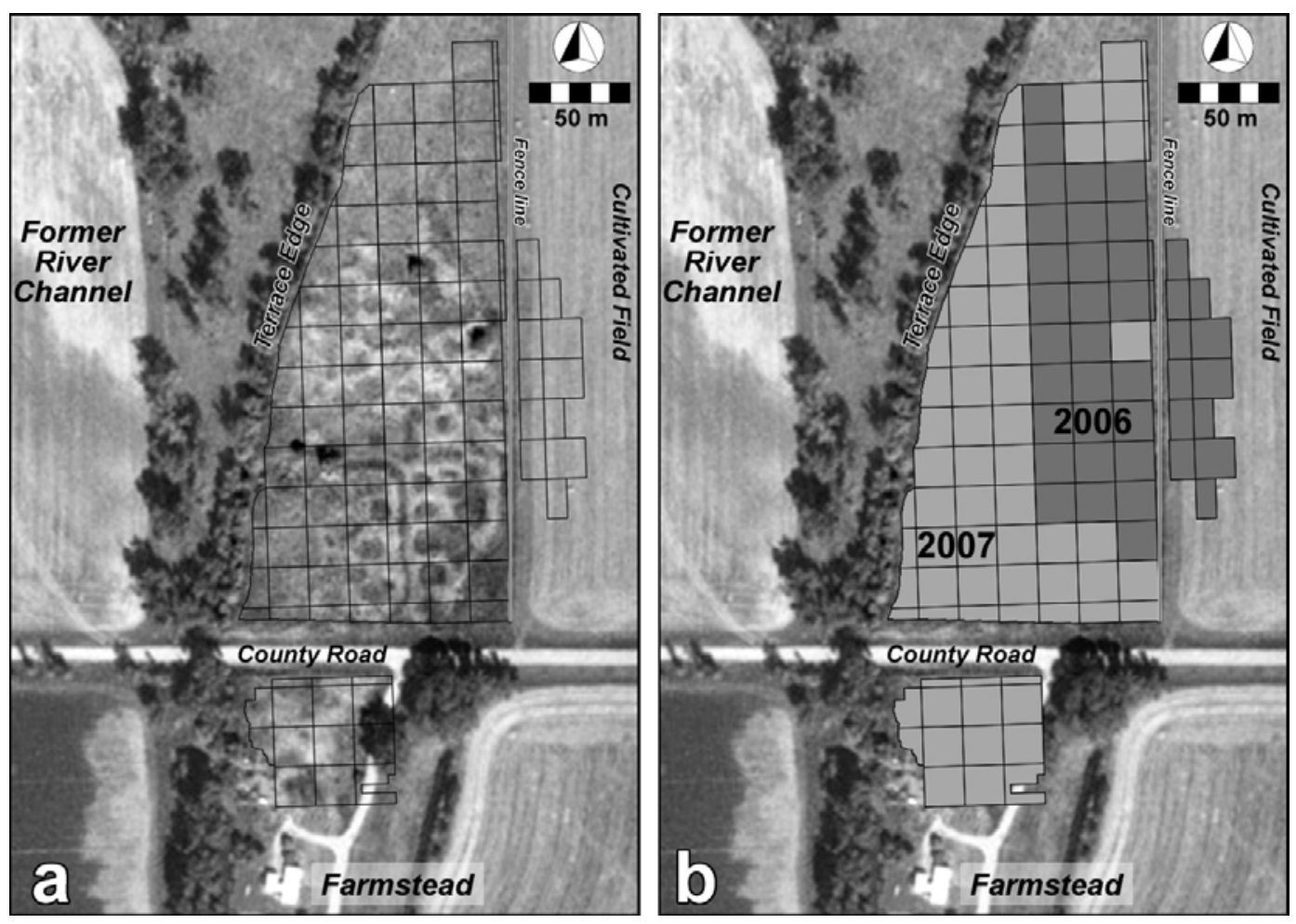

Figure 2.1.

Aerial view of the Larson site. a) USGS aerial photo dated September 17, 1997 showing extent of magnetic gradiometry survey grid. b) Depiction of magnetic gradiometry blocks surveyed in 2006 and 2007.

\section{The Magnetic Gradiometry Survey and Associated Results}

\section{Field Methods}

The magnetic gradiometry survey at Larson was conducted within three distinct areas, the principal site area north of the county road, a small site remnant south of the road, and a small region within the cultivated field east of the principal site area (Figure 2.1). The survey was uniformly conducted within 20 x 20 m survey blocks that allowed the work to be conducted piecemeal, with several units investigated each day. Personnel of the SHSND accurately located the corners of these $20 \mathrm{~m}$ units within the site's coordinate base using a total station. Each corner of a $20 \mathrm{~m}$ block was marked with a meter-long length of one-inch PVC pipe inserted into the ground. Geophysical surveys conducted within each block utilized fiberglass surveyor's tapes staked parallel to each other on the ground, typically two meters apart, to guide spatial location of the instruments during the surveys. Geophysical data collection is conducted along transects. A half-meter separation distance was uniformly employed between transects to yield high spatial resolution and the possibility of detecting archaeological features of small size. Within each transect measurements were acquired every $12.5 \mathrm{~cm}$, for eight measurements/m and 16 measurement $/ \mathrm{m}^{2}$. 
During 2006, 32 complete and 9 partial blocks of 20 m were surveyed, for a total of $15,400 \mathrm{~m}^{2}$ (1.54 ha; Figure 2.1b). In 2007, an additional 41 complete blocks and 30 partial ones were surveyed, for 20,883 $\mathrm{m}^{2}$ (2.09 ha; Figure $2.1 \mathrm{~b}$ ). This makes a total survey area of $36,283 \mathrm{~m}^{2}$ or 3.63 ha (Figure 2.1b). With 16 magnetic gradiometry measurements $/ \mathrm{m}^{2}$, a total of 580,524 were acquired.

\section{Theory and Instrumentation}

Magnetometry is a passive detection method that measures the sum of remanent and all forms of induced magnetism below the instrument (whether natural or anthropogenic). Magnetic gradiometry is a form of magnetometry that records differences between two sensors, separated vertically (the differencing removes constant temporal changes in the Earth's primary magnetic field). It has proven to be one of the most productive prospecting methods in the Northern Great Plains for several reasons. Intense heating of the soil in hearths or the occasional burned house generates pronounced thermoremanent anomalies. Magnetometry also responds to accumulations of material with high magnetic susceptibility - the ability of a substance to become magnetized by an inducing field, such as the Earth's. Topsoil tends to be more susceptible than subsoil due to several processes that include physical and chemical weathering that concentrates magnetic compounds, a fermentation process that changes them to more magnetic forms, and bacteria that accumulate magnetic minerals (Kvamme 2006b).

Although topsoil in the Northern Plains tends to be only mildly susceptible compared to other regions with older soils, detectable anomalies are nevertheless formed through a number of cultural processes. Abandoned subterranean storage pits (1.5-2 m deep, bell-shaped in crosssection, with a meter-wide orifice at the top and two-meter breadth at the bottom) and fortification ditches (U- to V-shaped and 1-2 m deep) eventually become filled with sediments originating by erosion from nearby topsoil, or were purposefully sealed by the occupants using the same material, forming large magnetic contrasts owing to the relatively greater volume of magnetically susceptible material they hold. Mounds built from topsoil likewise produce magnetic anomalies and this is especially true of mounded middens that are composed of more magnetically susceptible materials, such as broken ceramics, fire cracked rock, soil from hearth cleanings, and organic matter that promotes growth of bacterial forms that concentrate magnetite. Moreover, natural erosion of soil covering earthlodges, by wind, rain, or foot traffic (lodge roofs were often places of activity), often created small berms around their perimeters that represent a larger volume of magnetically enriched topsoil. All of these processes are further exacerbated in extended occupations because (1) fired clays, fire-cracked rock, and broken ceramics of high susceptibility are constantly introduced to settlement soils through hearth cleanings, reworking of burned deposits, pot breakage, and the like, and (2) the introduction of organic matter can promote growth of magnetite-concentrating bacteria. More details about anthropogenic contributions to soil magnetism are described in Kvamme (2006b).

The magnetic gradiometry survey at Larson was principally conducted with a Geoscan Research FM-256 fluxgate magnetic gradiometer (Figure 2.2a). This instrument collected all the magnetic data of 2006, and all results north of the county road in 2007 (Figure 2.1b). With field time running short toward the end of the 2007 season, it was decided to employ a second 
available gradiometer to insure complete survey of the entire site. This instrument was the Bartington 601 dual-sensor fluxgate magnetic gradiometer (Figure 2.2b). Both instruments are designed for the rapid measurement of magnetic information over broad areas, but the Bartington 601, with dual sensors, is at least twice as fast as the FM-256 (because only half as many transects need to be walked). Both instruments are capable of about $0.1 \mathrm{nT}$ resolution.

Vertical gradiometers record differences between magnetic measurements made by top and bottom sensors that are separated along a shaft. The bottom sensor is more sensitive to magnetic changes in near-surface soils than the top sensor (because magnetic field strength falls of with the cube of distance). The top sensor, on the other hand, is more sensitive to constant variations in the Earth's magnetic field. Differencing the two measurements removes the effects of changes in the Earth's field. The sensor separation of the FM-256 is a half-meter, but in the Bartington 601 it is a full meter. The consequence is somewhat improved sensitivity of the latter instrument, creating noticeable data compatibility issues. These differences were to some extent resolved by placing all the Bartington 601 survey blocks south of the county road and the FM256 survey blocks north of it so that both surveys were distinct, with no contiguous blocks. Furthermore, with the bottom sensor of the FM-256 at about $30 \mathrm{~cm}$ above the ground surface, the bottom sensor of the Bartington 601 was raised to about $38 \mathrm{~cm}$ above the ground surface, to reduce the latter's sensitivity to near-surface magnetic features. This tactic appeared to make the Bartington 601's data appear more compatible with the FM-256.
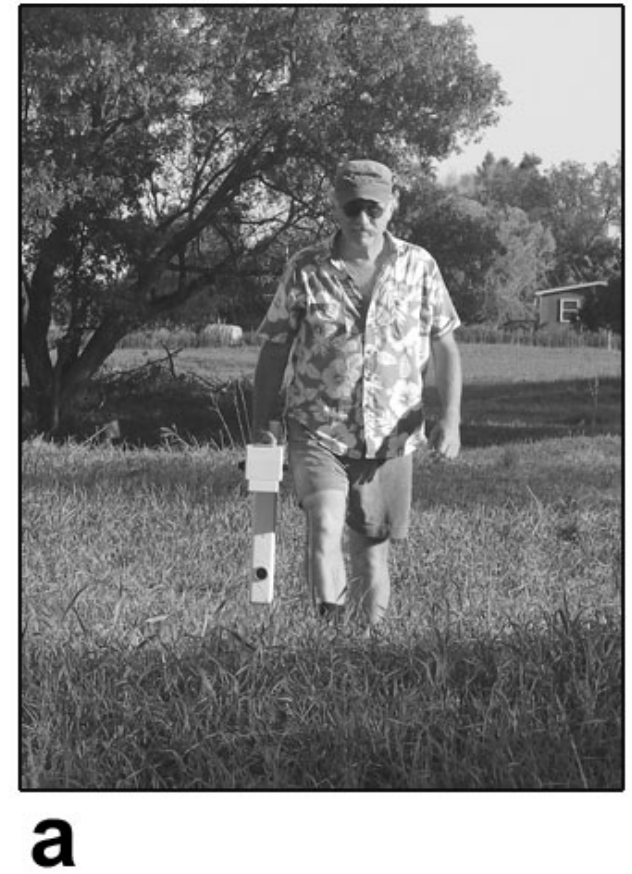

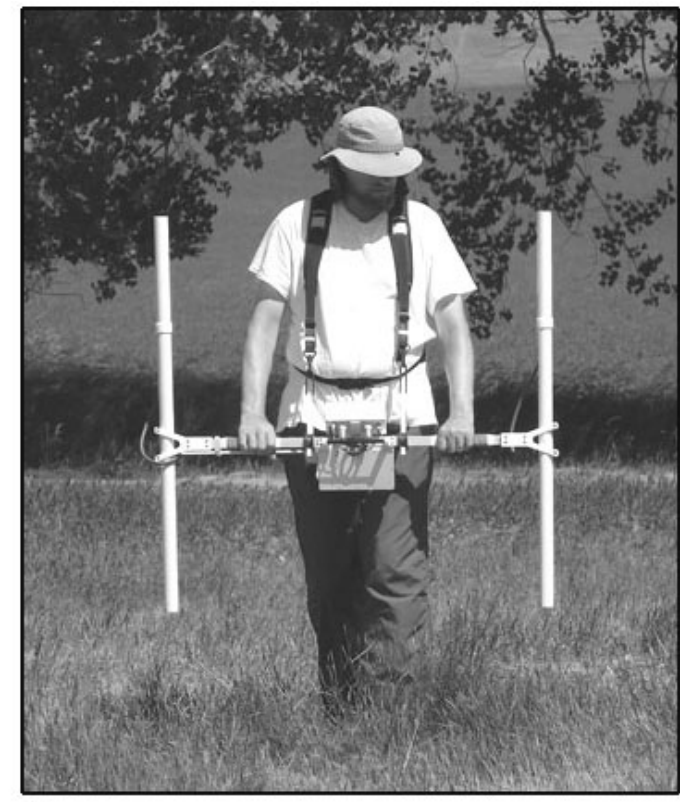

b

Figure 2.2. Instrumentation utilized for the magnetic gradiometry survey at Larson. a) Geoscan Research FM-256 fluxgate magnetic gradiometer. b) Bartington 601 dual sensor fluxgate magnetic gradiometer. 


\section{Data Processing}

The processing of magnetic gradiometry data sets is a complex topic. Because the data can be treated as imagery standard image processing algorithms apply, but specialized procedures are also necessary. Kvamme (2006b) overviews fundamental issues and operations relevant to magnetic data processing in archaeology. This task typically requires a series of ordered steps.

- Concatenation. The data from individual 20 m survey units are joined into a single composite in correct spatial arrangement.

- Data normalization. Fluxgate magnetic gradiometers tend to drift with temperature or with different headings (e.g., north vs. south in a zigzag survey), meaning that the average of the data moves away from an expected value of zero. Forcing the mean of each transect to equal zero normalizes these data, removing the effects of drift.

- Filtering. The application of several filters is commonly undertaken. A mild, Gaussianweighted low-pass filter is used to reduce statistical noise in the data and produce a "smoother" looking result.

- Contrast enhancement. Image quality is improved by “clipping” of high and low values in the data in order to achieve a better distribution of gray levels in an image for visualization of subtle features. In general, presented imagery in this report is clipped within plus or minus three or four standard deviations of the data mean.

- Interpolation. Estimates of additional measurements may be made for improved image continuity and interpretation, and to balance unequal sampling densities resulting from field collection methods (i.e., one-half meter between transects compared to one-eighth meter between measurements along transects). The magnetic data in this report were resampled to a uniform .25 x .25 m sampling density (maintaining the original16 measurements $/ \mathrm{m}^{2}$ ).

Results

The magnetic gradiometry surveys at Larson was highly successful in both years, 20062007, a result consistently demonstrated at village sites of the Northern Great Plains (e.g., Kvamme 2003; Kvamme and Ahler 2007). Numerous anomalies are clearly revealed, many unquestionably of cultural origin (Figure 2.3). These anomalies may be classified into several groups representing those generated by likely prehistoric features and those originating from recent or modern sources. Many of the principal anomalies interpreted here are labeled in Figure 2.3b. These anomalies are discussed in the following sections, beginning with the results of the excavation program of 2006 and the coring program of 2007, which validated and clarified many anomaly identifications. In order to present a comprehensive discussion, anomalies discovered and addressed in the 2006 study are again presented here, drawing freely from the report of that year and expanding discussions with new evidence and details (Kvamme 2006a). A clear, unlabeled, page-size graphic of the magnetic gradiometry results is presented in Figure 2.30. 
Evidence from Excavations in 2006

In 2006, several excavations were performed at the locations of significant anomalies. Specifically, the aim was to obtain material culture samples and dates for the early occupation of

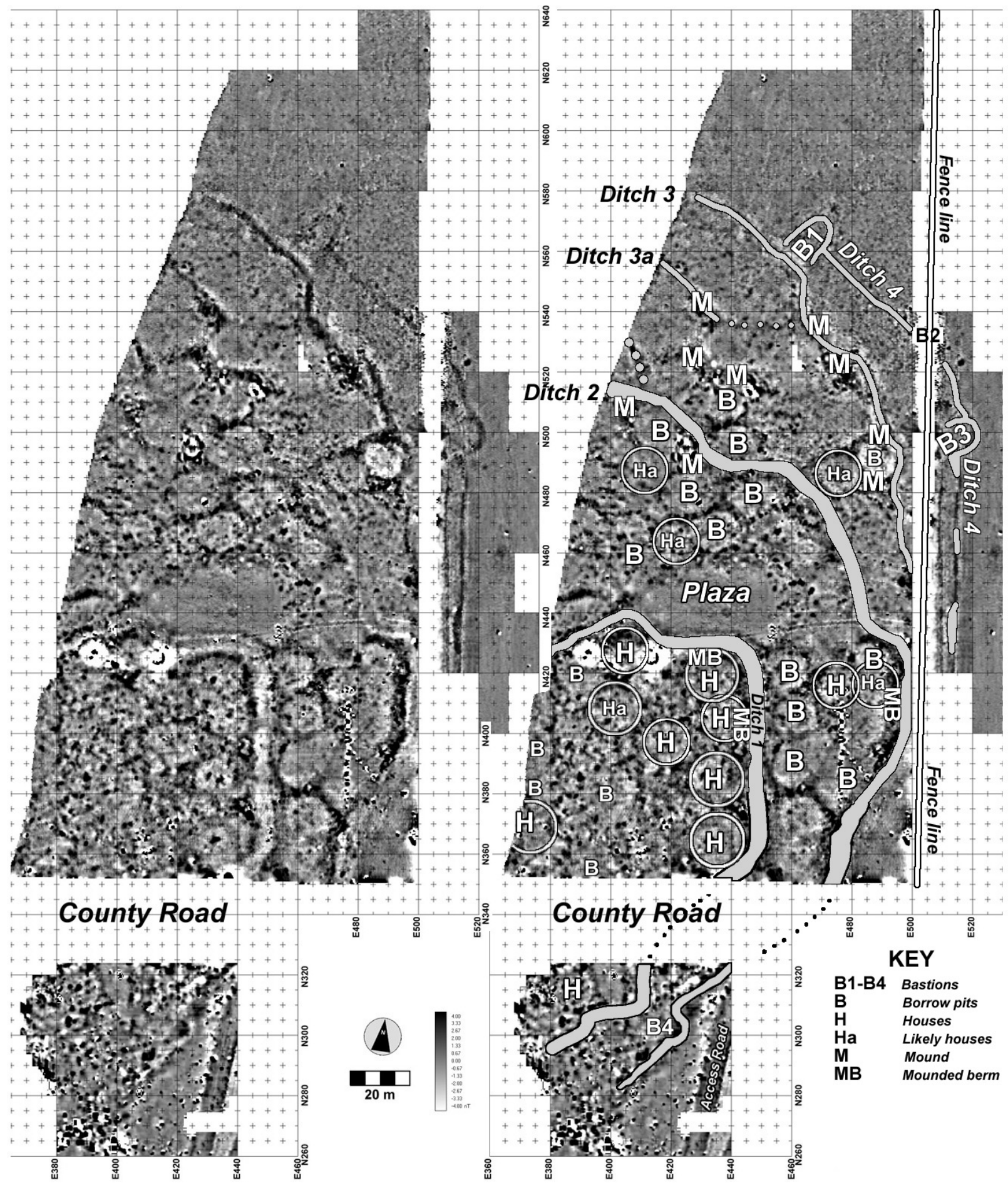

Figure 2.3. The magnetic gradiometry survey at Larson showing a) the basic data without interpretive labels and b) with interpretations. Numbers and letters in (b) refer to specific anomalies or classes of anomalies discussed in text. 
Larson, so focus was placed on the outer village margins guided principally by the magnetic gradiometry evidence. Mark Mitchell of PCRG and Fern Swenson of the SHSND directed the excavations. Results were obtained from three pit excavations, Blocks A, D, and F, and excavations of Ditches 3 and 4, with locations shown in Figure 2.4a and illustrative photos in Figures 2.4b-f.

- Block A, measuring 1 × $2 \mathrm{~m}$, was placed over the north half of an apparent storage pit anomaly with a moderately high maximum of $3.2 \mathrm{nT}$ (Figure 2.4a, inset). Excavations revealed a large undercut pit feature with lenses of magnetic fill adjacent to a large post pit (Figure 2.4b).

- Block $D$, measuring 1 x 2 m was, unfortunately, incorrectly located a meter too far east (Figure 2.4a, inset), resulting in the targeted storage pit (with a maximum of $3.0 \mathrm{nT}$ ) being missed by the excavation (the edge of it is visible in the right wall in Figure 2.4c). Revealed, however, was a large post pit not associated with an anomaly. Although pits filled with settlement soils tend to be moderately magnetic, it is hypothesized that post pits may not exhibit magnetic anomalies because they were originally filled with wood that later decomposed into soil.
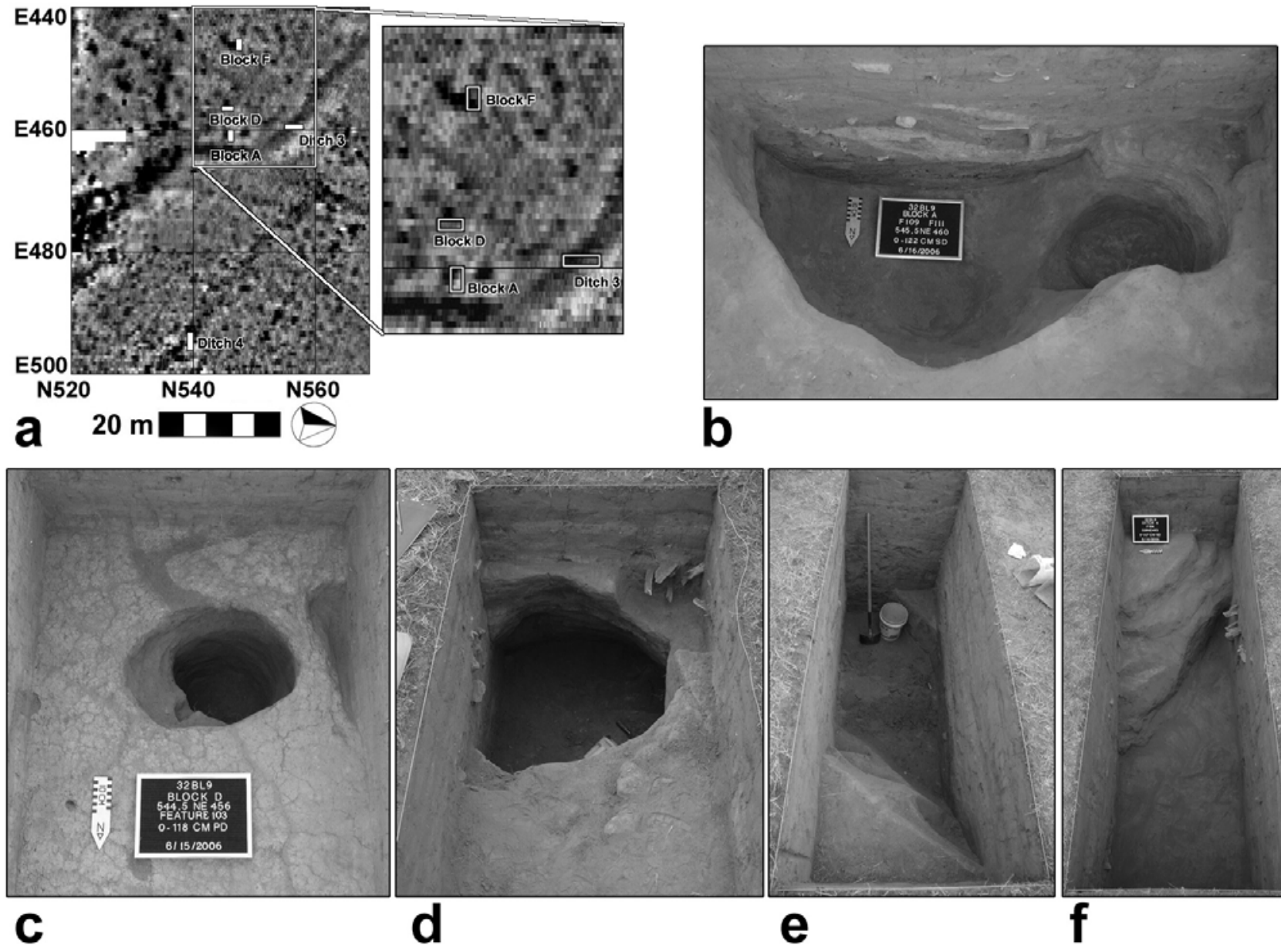

e

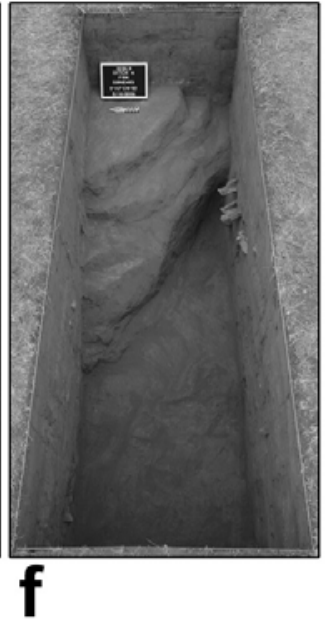

Figure 2.4. Excavations of features associated with anomalies at Larson in 2006: a) location map, b) post hole (right) and undercut pit (left) in Block A, c) post hole in Block D, d) undercut storage pit in Block F, e) Ditch 3, f) Ditch 4. 
- Block $F$, measuring 1 x $2 \mathrm{~m}$, was excavated over the eastern of a series of closely spaced anomalies that may represent three adjacent storage pits (Figure 2.4a, inset). The maximum of this anomaly measures $3.84 \mathrm{nT}$. A very large undercut storage pit was revealed adjacent to a smaller pit containing a collection of bison bone (Figure 2.4d).

- Ditch 3, measuring 1 x 3 m, excavations revealed a deep fortification ditch (Figure 2.4e).

- Ditch 4, measuring 1 x 3 m, excavations revealed a deep fortification ditch (Figure 2.4f).

Analysis of Hearth and Pit Data by Coring Program of 2007

The coring program carried out by members of the SHSND and PCRG in 2007 was designed to validate magnetic anomalies and learn more details about Larson's archaeological content and geological history. Two archaeological feature types are explored here, hearths and storage pits. The basic data, provided by PCRG, are presented in Tables 2.2 and 2.3 and the locations of cored anomalies are mapped in Figure 2.5. Tables 2.2 and 2.3 also include maximum magnetic measurements recorded over each hearth and storage pit by the gradiometry survey.

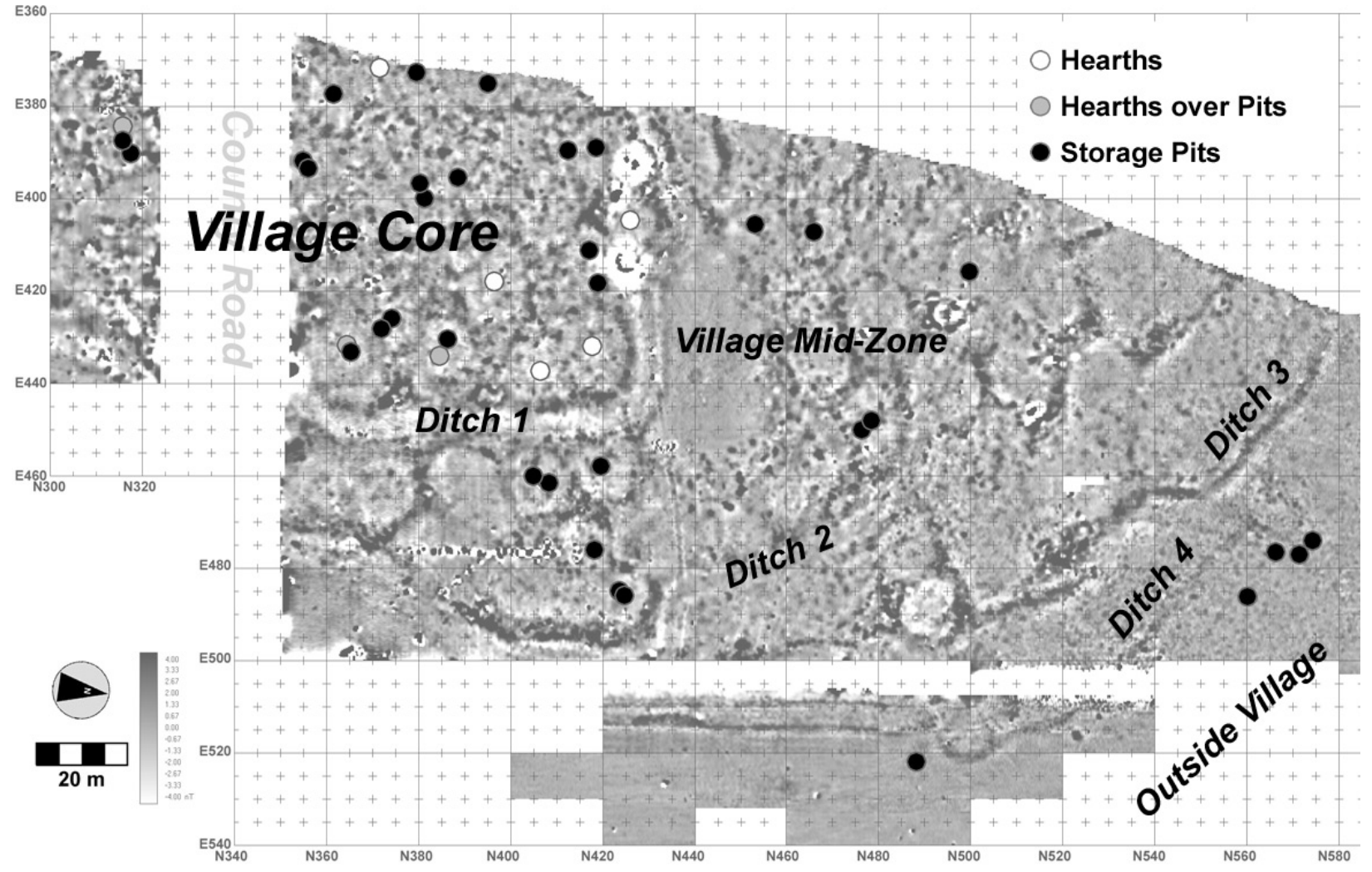

Figure 2.5. Magnetic anomalies cored at Larson Village identified as hearths, hearths over pits, or storage pits.

- Hearths. One result of the coring program was confirmation of the existence of eight hearths, of which three were placed over former storage pits, an apparently common occurrence. All of the identified hearths appear to be located near the centers of large surface depressions, undoubtedly former houses (Figure 2.5). 
One might expect that hearths located over former storage pits should be more magnetic than those that are not because a magnetometer responds to the sum of all magnetism, and the magnetic input of a storage pit plus an overlying hearth should generally be greater than a hearth alone, all other considerations being equal. The evidence may support this idea with mean magnetism of hearths located over pits at $9.03 \mathrm{nT}$ and isolated hearths yielding a mean of $7.67 \mathrm{nT}$. Yet, the lower mean of the latter may be due to a single small measurement (perhaps a little-used hearth). Figure 2.6 illustrates graphs of the data and basic summary statistics. With the small samples available the apparent difference is not statistically significant, with a $t$-test yielding $t=0.677, n_{\mathrm{H}}=5, n_{\mathrm{H}-\mathrm{P}}=3, p=.52$. Obviously, more data and larger samples will be necessary to test this principle, because hearth-to-hearth as well as pitto-pit magnetic variation is so large.
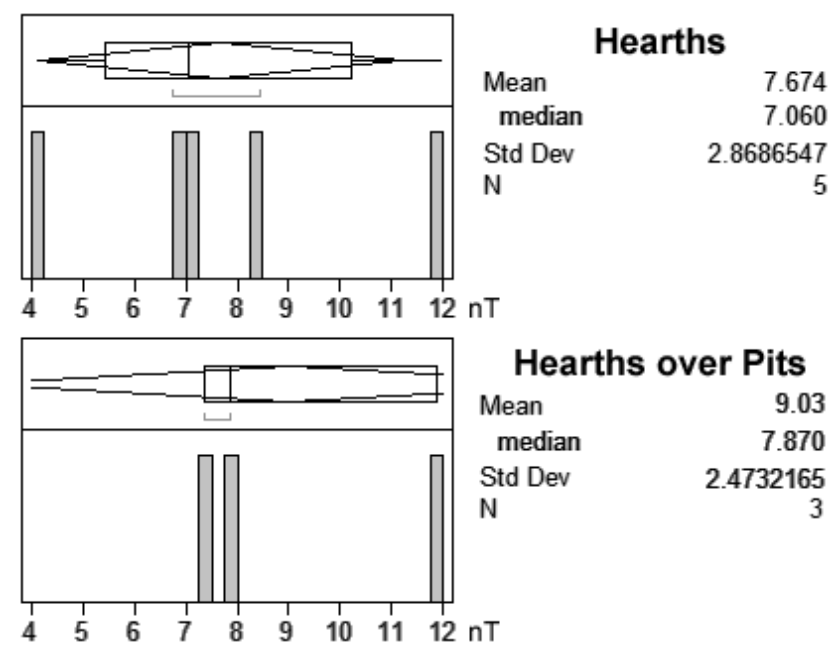

Figure 2.6. Graphs and apparent magnetism statistics for the two types of hearths at Larson Village.

- $\quad$ Storage pits. Over 35 magnetic anomalies that were cored were classified as pits, but several were so close together that they manifested only a single anomaly, so only 35 are analyzed here. Their locations are shown in Figure 2.5, and basic data are given in Tables 2.3. As with the hearth data, maximum magnetic measurements were extracted from each pit. As previously noted, a magnetometer responds to the sum of all magnetic materials below it, so deeper pits should, on the average, exhibit greater magnetism, and maximum depth from the surface to the bottom of each pit was recorded in the coring data (Table 2.3). What is unknown are the depths to the tops of the pits, but this depth may be much less variable (it will, nevertheless, represent one source of error). Apparent magnetism by pit depth is plotted in Figure 2.7. The data illustrate a mildly positive relationship that is statistically significant $(r=.422 ; p=.012$ ), meaning that deeper pits tend to exhibit greater magnetism (owing to greater volumes of magnetically susceptible materials). The linear regression equation (with intercept constrained to zero; Figure 2.7) indicates that for every centimeter of depth within a pit (which increases its volume), magnetism increases by .038 nT.

As can be seen in Figure 2.5, storage pits were cored throughout the site, with 19 in the village core area (inside Ditch 1), 11 in a mid-zone between Ditches 1 and 2, and 5 outside of the fortified village area, beyond Ditch 4 . This distribution offers an unusual opportunity to examine differences in apparent magnetism between areas of the site. As noted earlier, it is well known that human occupation exacerbates soil magnetism through the introduction of 


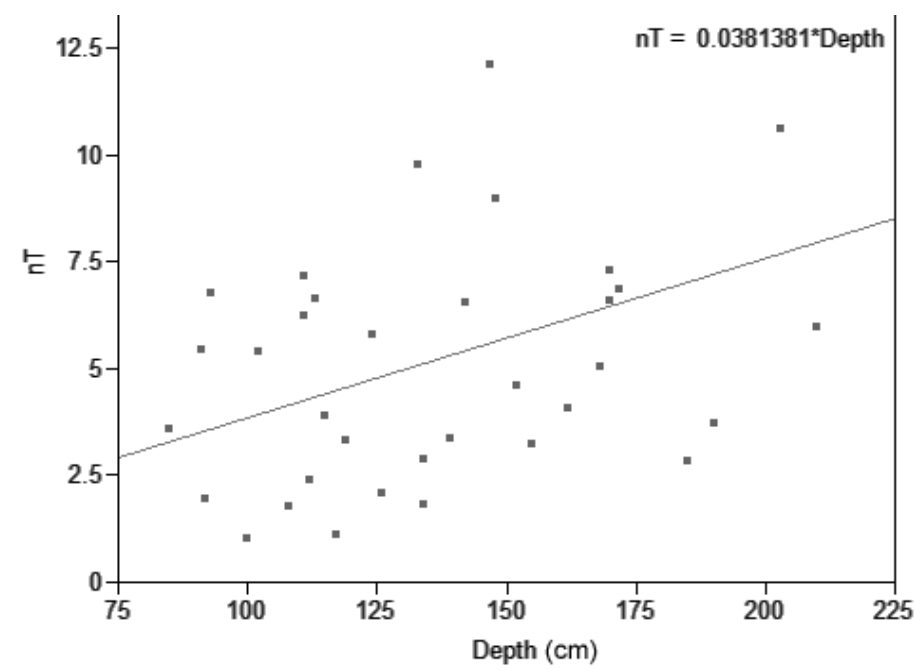

Figure 2.7. Graph of apparent magnetism (in nT) by pit depth in centimeters showing a weak positive relationship $(\mathrm{r}=.422)$.

fired materials to the soil, reworking of fired areas (e.g., hearth cleanings), and the introduction of organic waste that may promote growth of bacteria that concentrate magnetic compounds (see Clark 2000). It can be inferred that the village core was occupied a longer period than the mid-zone, and that the outer area was barely occupied at all. This implies that anomalies generated by comparable features (i.e., storage pits) should exhibit highest magnetism in the village core, moderate levels in the mid-zone, and relatively low levels outside the village area. This, indeed, appears to be the case. As shown in Table 2.1 and Figure 2.8, pit magnetism is highest in the longer-occupied village core and decreases as one moves outward to its periphery. This phenomenon may reflect increased magnetic susceptibility of storage pit fill materials within the village core, with decreased levels in less occupied areas of the village.

The foregoing of course assumes that storage pit sizes, approximated by their depths, are approximately equal in each site region. The data show that mean pit depths are about the same in the village core and mid-zone, but they tend to be shallower outside the village (Table 2.1; see raw data in Table 2.3). To remove this effect we may standardize the data by dividing the magnetic measurements by pit depth (Table 2.1). The results indicate the same relationship of greater magnetism in the longer-occupied core (in nT/cm) with decreasing magnetism moving toward the village exterior. Differences between the village core and both other regions are statistically significant (Core-Midzone: $t=2.55, n_{\mathrm{C}}=19, n_{\mathrm{M}}=11, p=.016$; Core-Outside: $t=3.41, n_{\mathrm{C}}=19, n_{\mathrm{O}}=5, p=.002$ ), although that is not the case between the MidZone and Outside areas, possibly owing to small sample numbers (Midzone-Outside: $t=1.38$, $\left.n_{\mathrm{M}}=11, n_{\mathrm{O}}=5, p=.177\right)$.

- Hearths vs. storage pits. Finally, and more significantly, a comparison must be made between the apparent magnetism of hearths versus storage pits, a phenomenon of some interest to Northern Plains archaeo-geophysics. In plan-view monochrome magnetic maps (e.g., Figure 2.3, 5) anomalies associated with hearths look much the same as anomalies generated by subterranean storage pits - they are roughly circular in shape and measure about 1-2 $\mathrm{m}$ in diameter depending on their size, magnetic intensity, and image contrast. In other words, they look nearly identical in such maps, making it difficult to distinguish between them. Bales and Kvamme (2005), at Huff Village (32MO11), and Kvamme and Ahler 
Table 2.1. Mean apparent magnetism and pit depth by site region.

\begin{tabular}{|l|r|r|r|}
\hline Region & Core & $\begin{array}{r}\text { Mid- } \\
\text { zone }\end{array}$ & Outer \\
\hline $\begin{array}{l}\text { Mean } \\
\text { nT }\end{array}$ & 6.95 & 3.90 & 1.96 \\
\hline $\begin{array}{l}\text { Mean pit } \\
\text { depth-cm }\end{array}$ & 146.2 & 138.2 & 108.0 \\
\hline $\begin{array}{l}\text { Mean } \\
\text { ratio: } \\
\text { nT/Depth }\end{array}$ & .048 & .031 & .018 \\
\hline $\mathbf{N}$ & 19 & 11 & 5 \\
\hline
\end{tabular}

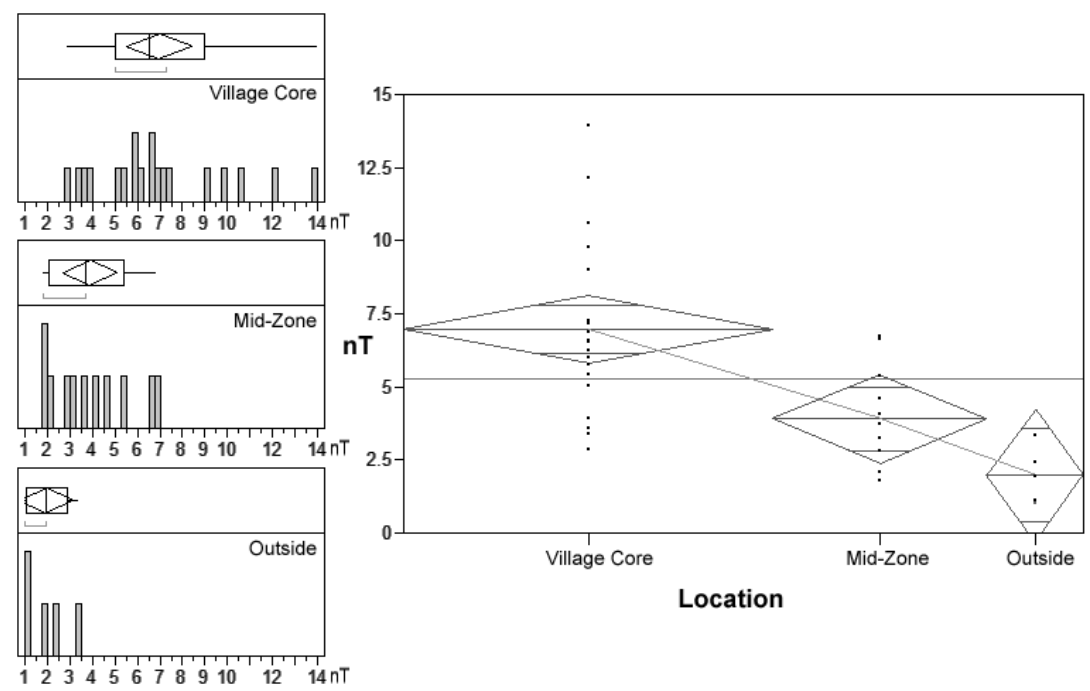

Figure 2.8. Histograms and box plots (left) and data plots with distribution diamonds (right) for the magnetic data by location showing differences, most blatantly by the line connecting means in the right graphic.

(2007), at nearby Double Ditch (32BL8), both demonstrate that, statistically, hearths tend to exhibit significantly greater magnetism than storage pits, although a large amount of overlap occurs in their data distributions.

At Larson, the eight hearths and all 35 storage pits were analyzed, with results illustrated in Figure 2.9 (basic data are given in Table 2.3). As found at the other sites, mean apparent magnetism exhibited by hearths is significantly greater than for storage pits (a $t$-test gives: $t=2.45, n_{\mathrm{H}}=8, n_{\mathrm{P}}=35, p=.018$ ) but, again, large overlap occurs between the distributions

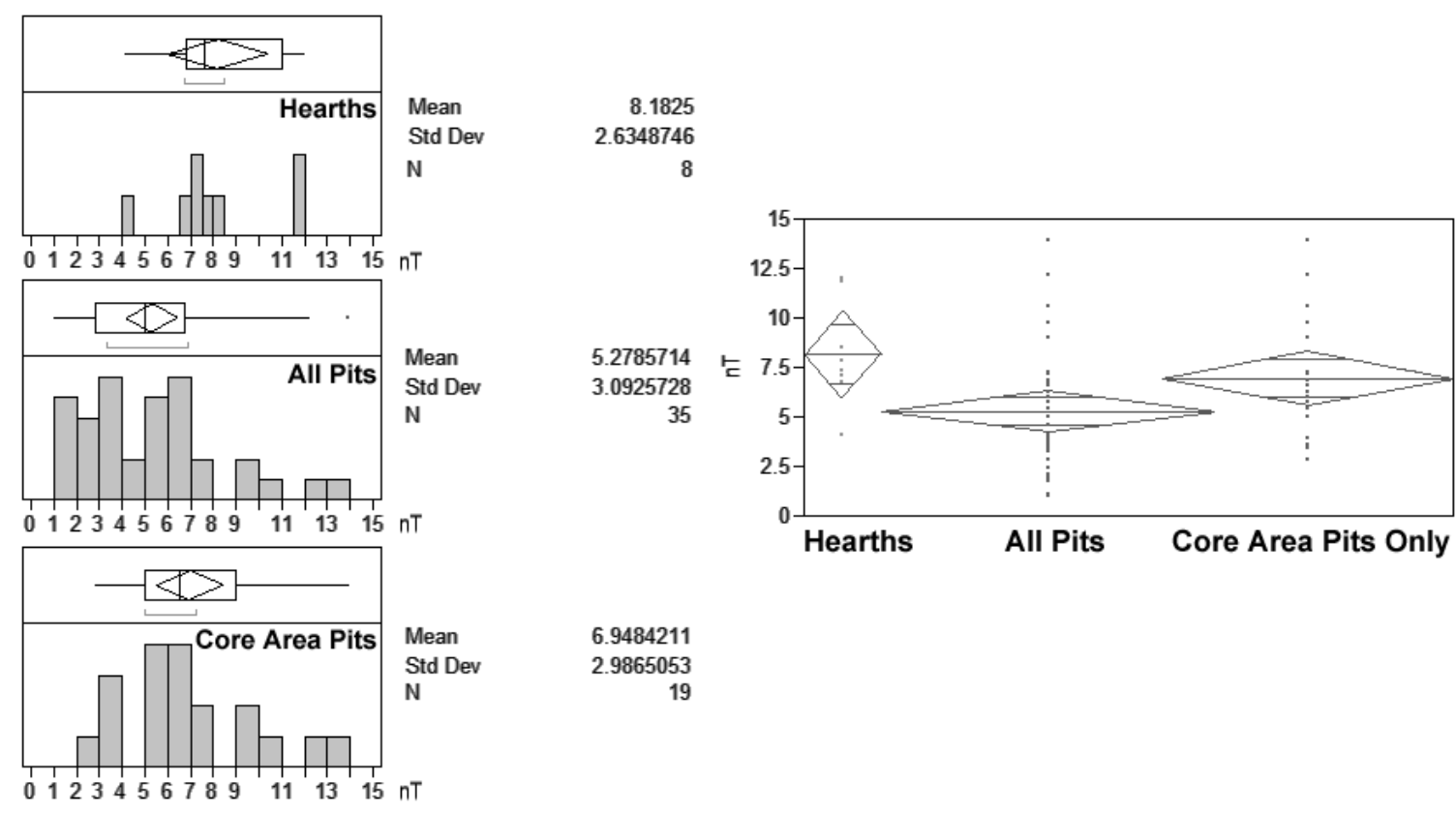

Figure 2.9. Comparison of magnetism between hearths, all storage pits, and core area storage pits only. 
(Figure 2.9). It might be noted that all hearths occur within the village core (Figure 2.5), so it is germane to ascertain whether hearths tend to exhibit greater magnetism than storage pits when considering this area alone. After all, it is demonstrated in Figure 2.8 that pits in the village core exhibit higher magnetism than elsewhere. Analysis of hearths and pits confined to the village core reveals that although there is a mean difference of over $1.2 \mathrm{nT}$, with hearths higher, that difference is not statistically significant (a $t$-test gives: $t=1.01, n_{\mathrm{H}}=8$, $n_{\mathrm{P}}=19, p=.321$ ) and the hearth distribution is fully overlapped by the storage pit distribution (Figure 2.9). Obviously, additional research is needed in this area, with more samples of each type and better distributions of samples.

\section{Fortification Ditches}

Four fortification ditches are defined at Larson Village on the basis of the magnetic gradiometry surveys, and other lines of evidence. Although precise dating has been problematic, a best estimate based on radiocarbon samples from the 2006 excavations points to a time range between 1500-1650 for the outer village area (with more evidence toward the earlier end, Mitchell 2007). Ditch 4 is probably the earliest construction with subsequent inner ditches presumably built afterwards as the village contracted, and Ditch 1 the youngest. Magnetic evidence present below supports this interpretation.

- $\quad$ Ditch 1. Ditch 1 is unambiguously revealed in the landscape on the north side of the county road, and is presently more than a meter deep and readily seen in the aerial photograph (Figure 2.1a). Magnetically, it is indicated by a region of negative magnetism down its bottom portion (typically from -.5 to $-6 \mathrm{nT}$ ) sandwiched between areas of high positive magnetism along adjacent mounded berms of removed soil (from about 2 to 6 nT; Figure 2.3). This is a pattern that has been witnessed at several other sites with open, topographically expressed ditches, such as nearby Double Ditch (Kvamme and Ahler 2007). It represents a lack of magnetically enriched topsoil along the ditch bottom-presumably removed by its excavation - with mounding of the spoil adjacent to the ditch (and thus elevated magnetism). Most of this mounding occurs on the inside edge of the ditch, and the magnetic data testify to this berm with massive and larger-magnitude anomalies (see below for a more detailed analysis of ditch magnetism).

South of the county road the course of Ditch 1 is much less clear due to the extensive historic modification of the surface through homesteading and farming, as can be seen in mid-20th century aerial photographs (Figure 2.10). Contrast enhancements of these photos gives subtle hints of the course of Ditch 1 south of what is now the county road but what was then a mere field boundary (Figure 2.10 a,b). The Ditch apparently maintained a southwestern direction, but perhaps with a few small bends and turns. Interpretations are given in Figure 2.10 c,d. These data shed light on the magnetic gradiometry mapping of this region. Indeed, it is riddled with numerous dipolar anomalies that originate from ferrous metal artifacts from the historic occupation and recent trash, which further serves to obfuscate hints of the ditch. The lack of continuity with the north part of the village caused by the county road is a clear disadvantage of the gradiometry map. Close inspection, however, reveals subtle positive lineations in the approximate region in which Ditch 1 should 
be located, which could very well point to the likely berms of positive magnetism lying along the edges of the ditch (as occurs north of the road; Figure 2.11a). A hypothetical course for Ditch 1, based on the magnetic evidence, is given in Figure 2.11b that appears to parallel the hints in the aerial photography.
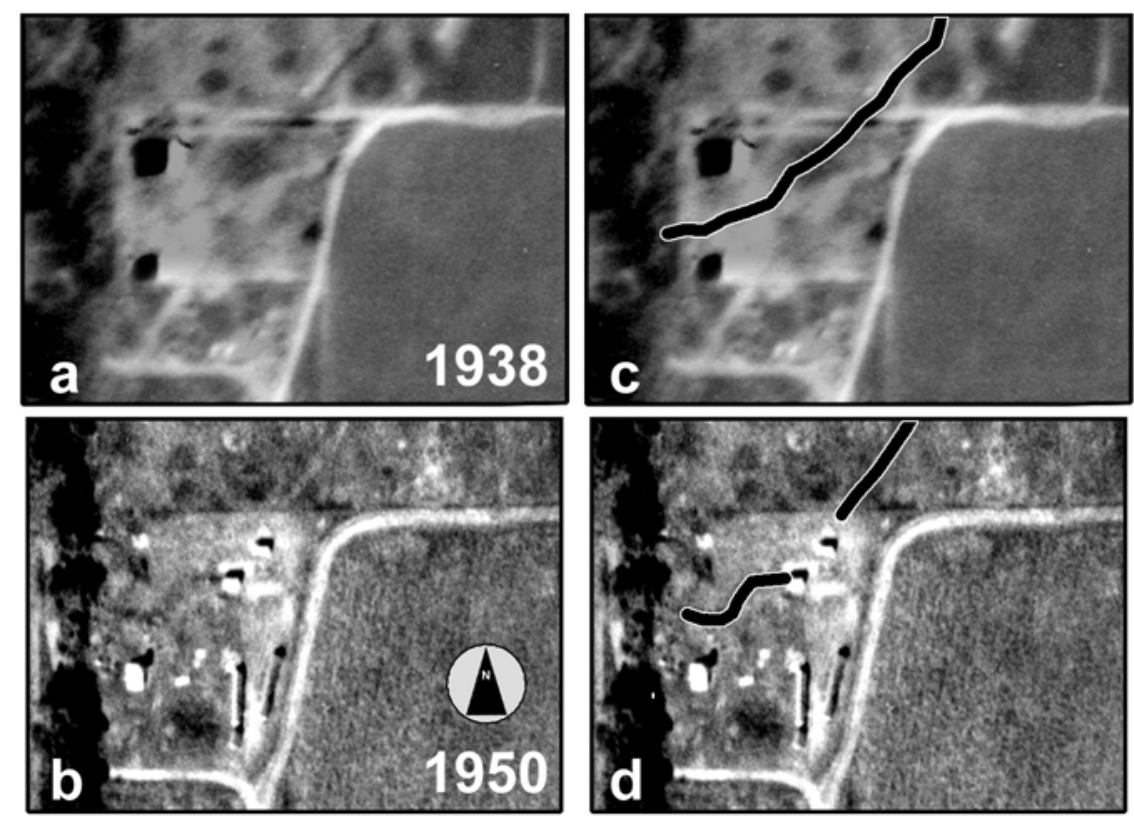

Figure 2.10. Contrast enhanced aerial photographs from (a) 1938 and (b) 1950, with interpretations given in (c) and (d), respectively.

- Ditch 2. Unlike Ditch 1, the course of Ditch 2 is not entirely certain north of the county road (Figure 2.3). For this reason several lines of evidence are examined here, including aerial photography and the topographic surface, all of which give additional hints about the location of this partially hidden ditch. Portions of it seem to be clearly visible in aerial photography, although its course is vague at its northwestern terminus and there is uncertainty to the southeast where it meets the county road (Figure 2.12a). On the surface, much of this ditch is subtly visible in the surface topography as a small and narrow linear depression, particularly north of the village core from N420-490. The topographic surface model produced by this project (described in a later seciton) yields further evidence. A relief map derived from it, illuminated from the north, appears to robustly indicate much of Ditch 2, although its course is less certain to the southeast once again (Figure 2.12b). A possible alternative course that coincides with some magnetic evidence is also suggested at its northwestern end by the dotted line.

The magnetic gradiometry data generally parallels the other lines of evidence (Figure 2.12c). Magnetically, the form of Ditch 2 is identical to Ditch 1, with low or negative magnetism (from .5 to $-4 \mathrm{nT}$ ) along much of its course with adjacent and positive magnetic berms that are more robust on the interior village edge (ranging as high as 9 nT; Figure 2.12c). This soil mounding is contiguous to the south (from about N430 to the county road), but appears spottier elsewhere with evidence of discrete and small anomalies along its outside edge. The magnetic evidence of Ditch 2 is very unclear as it proceeds northwest beyond the E440 line (Figure 2.12c). Extremely subtle magnetic hints suggest a course that parallels the aerial and topographic evidence, with a terminus labeled "1" in Figure 2.12c. Yet, a robust, 


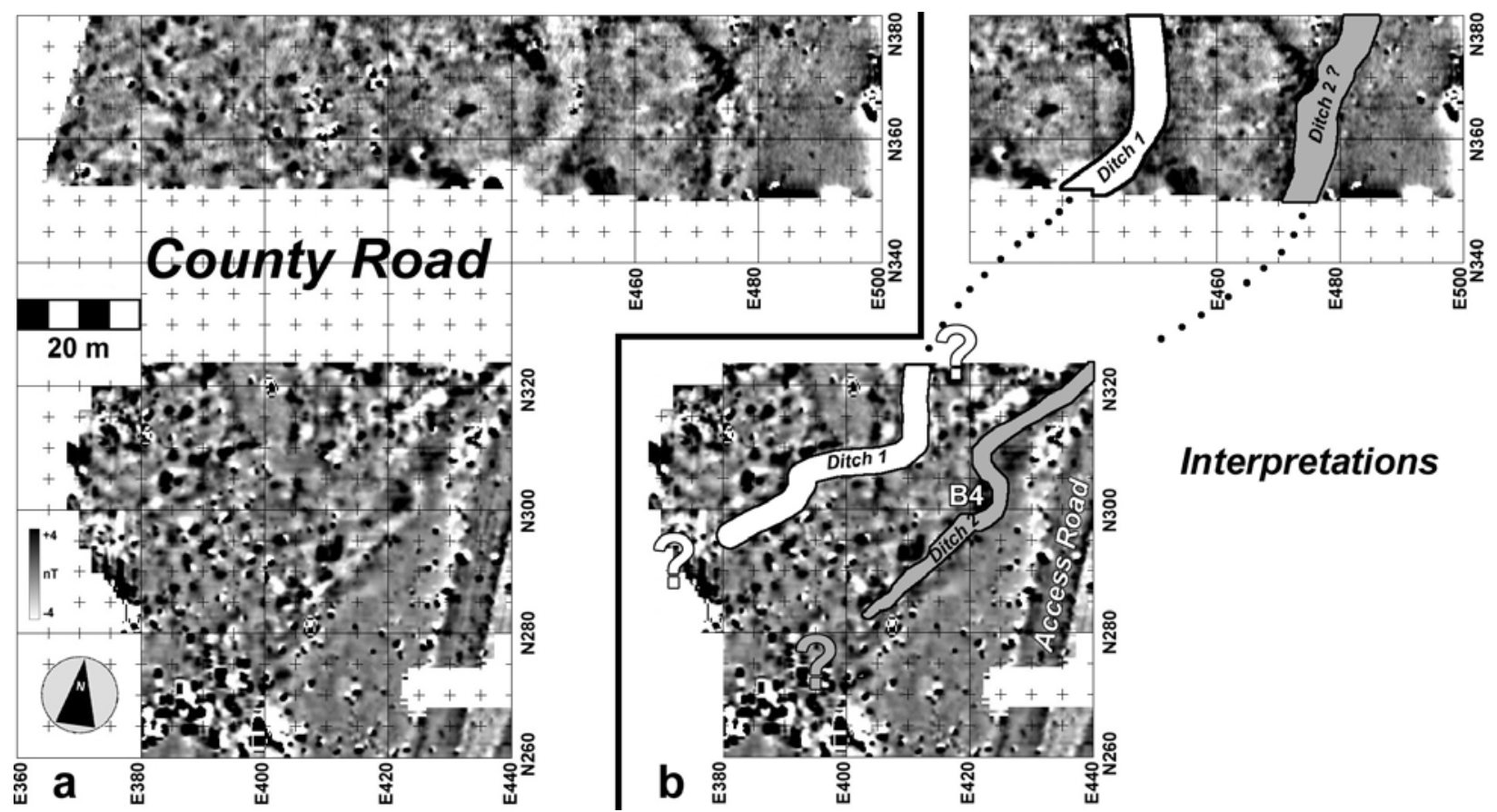

Figure 2.11. Evidence of fortification Ditches 1-2 in magnetic gradiometry results south of the county road. A) Raw data. B) Interpretations.

linear magnetic anomaly may be a better candidate (labeled "2"), especially because hints of a linear feature can also be seen at this locus in the topographic surface (Figure 2.12b, dotted line).

There is no surface or certain evidence in aerial photography of Ditch 2 south of the county road (Figure 2.10). Magnetically, a strong positive linear anomaly can be seen immediately south of the road, at about E435, N320, strongly suggestive of a ditch berm (Figure 2.11a). This lineation continues less robustly for nearly $40 \mathrm{~m}$ to the southwest, but unfortunately becomes mixed up in a mass of iron-cause dipolar anomalies from the historic occupation (Figure 2.11a). Significantly, west of this line magnetic anomalies are quite varied pointing to the presence of archaeological features (e.g., houses, pits), but east of this line the magnetic background is completely smooth or uniform (aside from dipolar anomalies associated with iron and a large linear anomaly caused by an access road). If that line represents the course of Ditch 2 (Figure 2.11b), then it was a boundary between the village and unmodified exterior deposits that were never occupied (i.e., Ditch 2 may have been the ultimate or "outer" ditch in this area of the village). The interpreted course of Ditch 2 follows a line of negative anomalies that hint at a small and weakly defined "loop" that possibly points to the locus of a former bastion (labeled "B4" in Figure 2.11b ). It is emphasized that this evidence is very weak, however.

- $\quad$ Ditch 3. The path of this ditch is revealed by magnetometry (Figure 2.3) and corroborated by the electrical resistance survey results of 2006 (see Kvamme 2006a) and excavation (Figure 2.4e). No surface evidence of it is visible in the landscape. It therefore represents a completely filled and buried ditch, magnetically visible owing to a composition of materials of high magnetic susceptibility (e.g., magnetically enriched topsoil or settlement soil likely 

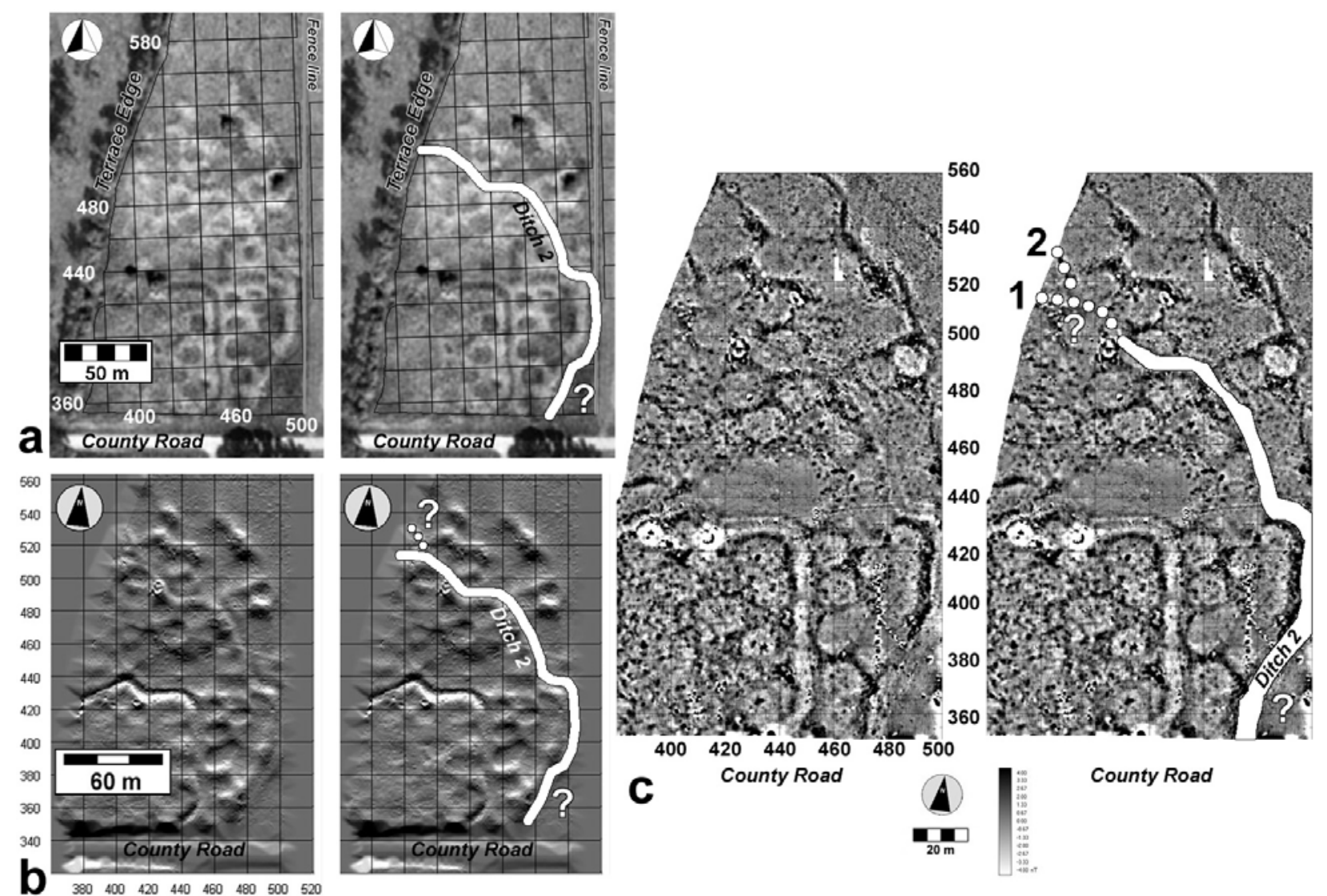

Figure 2.12. Evidence for the location of Ditch 2 with interpretations. a) Aerial photography. b) Relief shaded surface. c) Magnetic gradiometry.

comprises much of the fill). As with Ditch 3 at nearby Double Ditch (Kvamme and Ahler 2007), several low mounds or mounded middens that exhibit large magnetic anomalies overlie the course of portions of this ditch, obfuscating its course (labeled " $\mathrm{M}$ " in Figure 2.3b). Away from mounds, Ditch 3 is weakly magnetic in the north (about 1 to 2 nT north of N540), mildly magnetic along its central course (about 1 to 3 nT from N500-520), and more highly magnetic near the southern limits of its detection along the eastern edge of the site (about 2 to $5.5 \mathrm{nT}$ from N460-480). A second linear anomaly lying only $20 \mathrm{~m}$ south of Ditch 3 (at about N550) strongly suggests by its form, magnetic properties, and spatial arrangement another ditch or more likely, ditch segment (labeled "3a” in Figure 2.3b). By its course and position it may represent a later course for part of Ditch 3 as the village contracted, but this is highly hypothetical. Owing to magnetic noise introduced by the steel fence line at the eastern edge of the property (near E500) it is unclear whether Ditch 3 connects with the lines of Ditch 2, Ditch 4, or both (Figure 2.3). Ditch 3 may be associated with U-shaped bastions (see below for discussion of these features).

- $\quad$ Ditch 4. This ditch exhibits extremely weak magnetism, with most measurements at the subnanotesla level and few exceeding $1 \mathrm{nT}$, nearly at the sensing limits of the FM-256 magnetic gradiometer. Its form is similar to Ditch 3 and it is likely composed of midden materials and topsoil fill. The western terminus of this ditch lies at the eastern side of Bastion B1-no further magnetic evidence of it can be discerned to the west of this bastion (Figure 2.3). It 
also apparently connects with Bastion B3 but, because it does so near the outer tip of the bastion (defeating its defensive purpose), it is quite possible that the body of Bastion B3 is temporally associated with and intrusive from Ditch 3, post-dating the construction and use of Ditch 4 as the village contracted (see below for a discussion of bastions). Several distinct but robust indications of a ditch—probably Ditch 4-may be seen to the south of Bastion B3, but their visibility is partially obscured by anomalies generated by the edge of the contemporary cultivated field (see below). A third Bastion B2 is also associated with Ditch 4, but its presence is obscured in the gradiometry data by the presence of the steel fence under which it lies. It was revealed by the electrical resistance survey in 2006 (Kvamme 2006a), and is further discussed below. Ditch 4 was tested by archaeological excavation (Figure 2.4f).

\section{Fortification Ditch Magnetism}

Examining ditch magnetism along cross sections is insightful. Ditches 1-2, both discernable as depressions in the surface (the former highly so), were not filled in or sealed by the inhabitants as the village contracted or was abandoned. With the magnetically enriched Ahorizon removed by excavation "negative” magnetic measurements are characteristic, particularly in Ditch 1 (Figure 2.13a). This ditch exhibits much greater negative magnetism than Ditch 2 because the latter is probably older and has partially filled through natural erosion of nearby (magnetic) sediments. Pedogenesis may also contribute to its magnetism, which is somewhat elevated along its central course (Figure 2.13b).
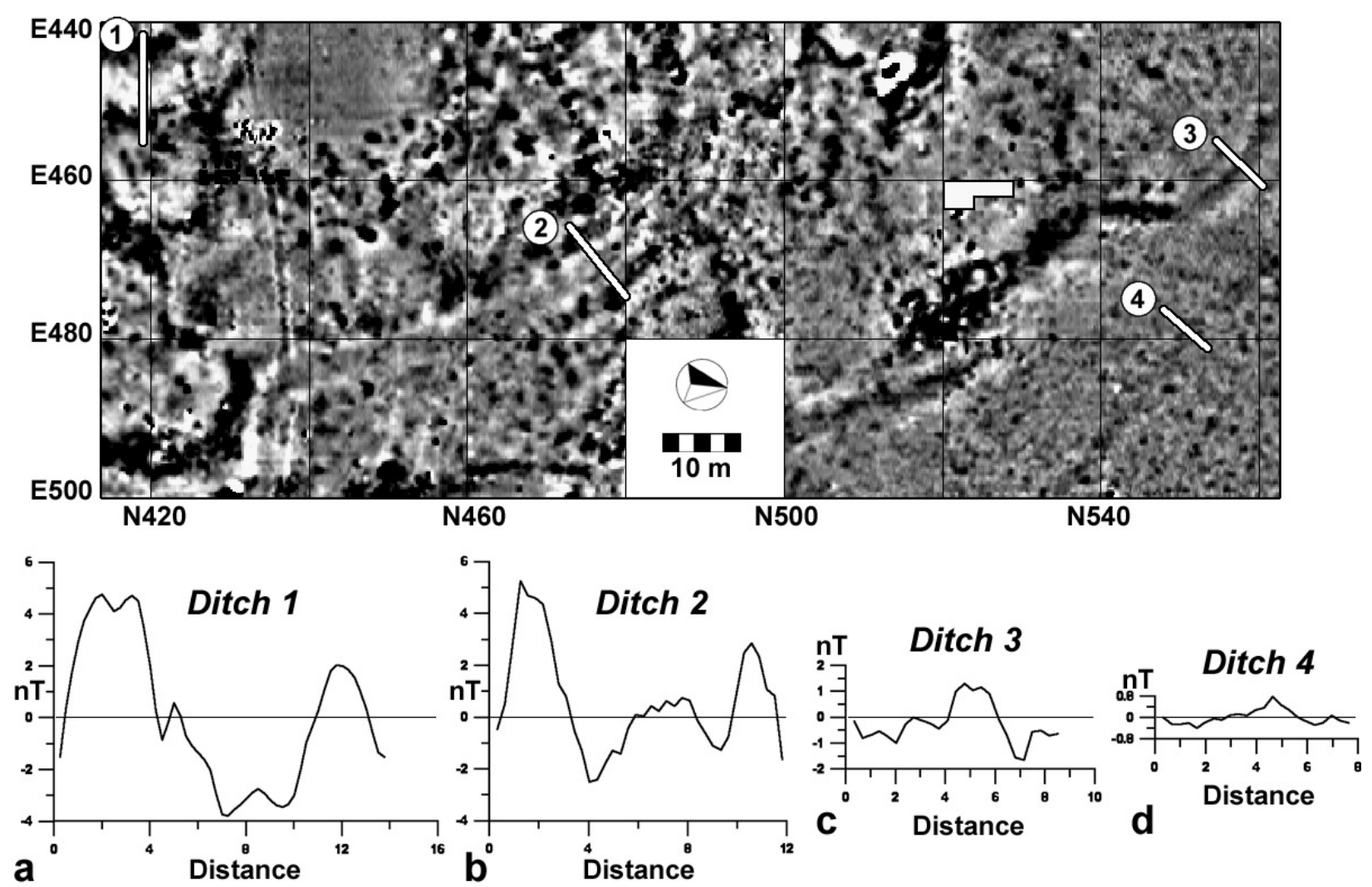

Figure 2.13. Magnetic profiles across Fortification Ditches 1-4 showing loci of profiles (top) and graphs of magnetic variation for a) Ditch 1, b) Ditch 2, c) Ditch 3, d) Ditch 4. All graphs are profiled at the same magnetic scale from west-to-east. 
Surface evidence of Ditches 3-4, on the other hand, is absent. These ditches were probably sealed by the occupants on purpose as the village contracted earlier in its history. Midden deposits, waste materials, and surface soils were undoubtedly employed, all of which possess elevated magnetic susceptibilities, contributing to positive anomaly creation (Figure 2.13c,d). That Ditch 3 is much more magnetic than Ditch 4 likely occurs because, closer to the longer-inhabited village core, the settlement soils used to fill the ditch are likely to be more magnetic through anthropogenic enrichment (Kvamme 2006b), although variations in depth and volume of fill also contribute to magnetic differences.

\section{Bastions}

Three certain bastions plus a fourth "possible" bastion were located by the geophysical surveys. Bastions B1-B3 appear most strongly to be associated with Ditch 4, but they may also or instead be associated with Ditch 3 (Figure 2.3b). Bastion B4 is rather tenuous (see above) and is associated with Ditch 2 (Figure 2.3b).

- Bastion B1. Located at the north end of the village, this bastion is associated with Ditch 4 and apparently Ditch 3, presumed to date later (Figure 2.3). It is U-shaped and measures about 25 $\mathrm{m}$ long by $10 \mathrm{~m}$ wide. The data suggest that both "ends" may connect with Ditch 3 , but it is also clear that Ditch 3 is continuous behind the bastion (Figure 2.14a). Perhaps the bastion was abandoned at some point and Ditch 3 was "closed up" behind it for a linear defense. Only a single side of the bastion, the eastern, connects with Ditch 4, with no evidence of this ditch to the west (Figure 2.14a). This anomaly is extremely subtle and "spotty" (less than 1.5 nT) with magnetic characteristics similar to Ditch 4, suggesting construction and fill components similar to that ditch.

- Bastion B2. This bastion was impossible to locate by magnetic gradiometry owing to the overlying steel fence. It was discovered by the electrical resistance survey of 2006 (Kvamme 2006a) which was unaffected by the fence's metal and was able to acquire data adjacent to both sides of the fence (Figure 2.14c). It measures about $17 \mathrm{~m}$ long by $12 \mathrm{~m}$ wide. This important discovery of that survey helps to define and fill out the nature of Larson's original outlying defenses, and adds insights concerning bastion form and spacing. Bastion B2 appears to be uniquely associated with Ditch 4 .

- Bastion B3. Although the magnetic magnitude of this anomaly is identical to Bastion B1 (measurements from about .5 to $1.3 \mathrm{nT}$ ), this bastion appears more robustly indicated because measurements are more consistent and the surrounding background is more uniform in value (at about $0 \mathrm{nT}$ ). Unfortunately, the nearby fence line introduces noise that serves to confuse the picture (Figure 2.14b). This bastion is at least $15 \mathrm{~m}$ long and about $11 \mathrm{~m}$ wide. It definitely connects with Ditch 4, but atypically in that Ditch 4 appears to abut it near its outer tip, which would defeat its defensive purpose on that side (Figure 2.14b). On the other hand, the corresponding resistance data seem to suggest that Ditch 4 meets this bastion more normally, further down its side, but the resistance contrast is very weak owing to the disturbed nature of the ground in this agricultural field (Figure 2.14c). It could be the case that Bastion B3 is associated with Ditch 3 and is superimposed over the (presumed) earlier 

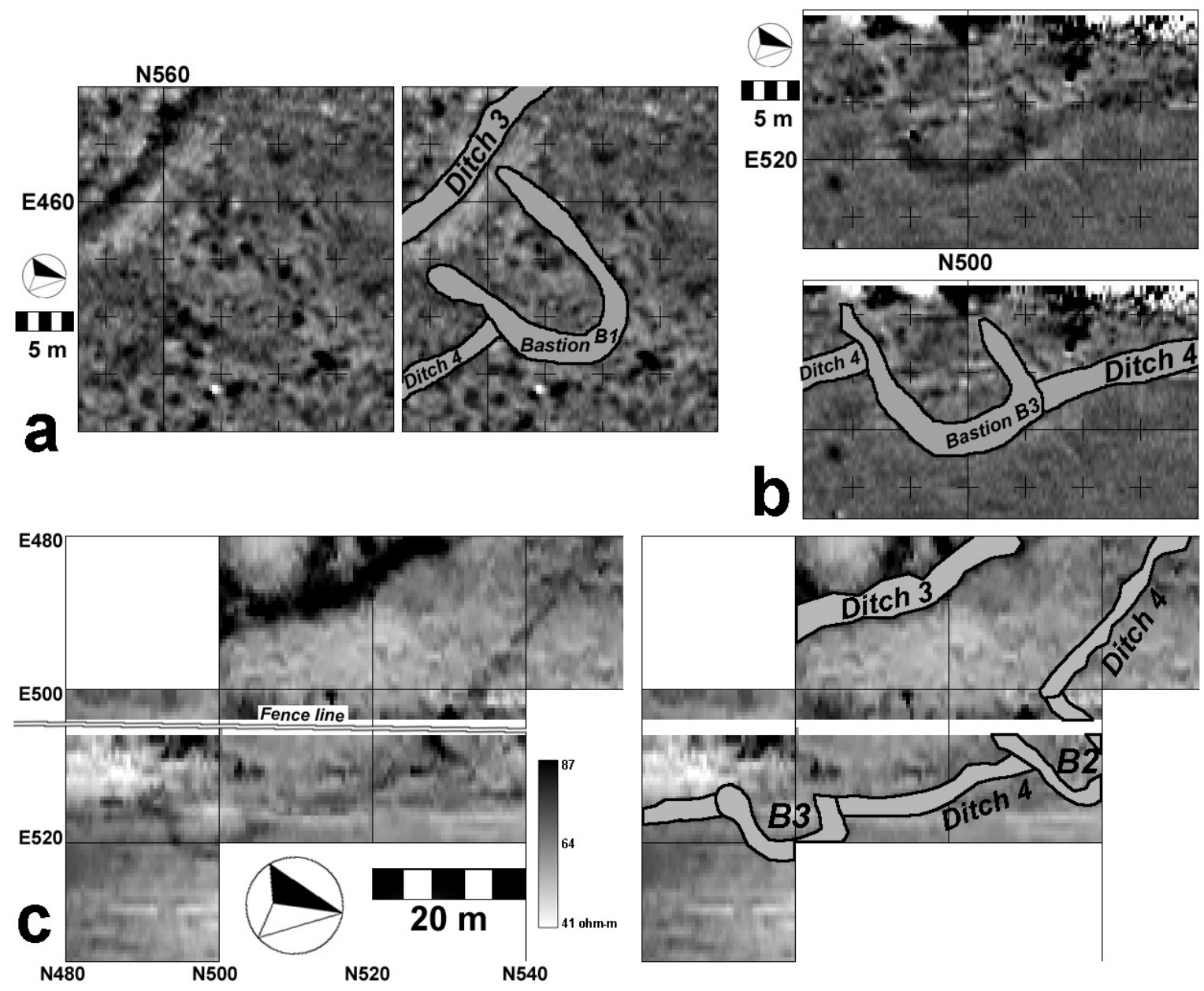

Figure 2.14. Evidence and interpretations of bastions associated with Ditches 3-4: a) Bastion B1 and b) Bastion B3 revealed by magnetic gradiometry, and c) Bastions B2-B3 as revealed by electrical resistance survey in the 2006 geophysical survey.

Ditch 4, yet the geophysical evidence shows little discontinuity between it and Ditch 4 and B3 does not appear to “connect” with Ditch 3 (Figure 2.3).

- Bastion B4. As discussed previously, the magnetic evidence for Bastion B4 is extremely weak and is only suggestive (Figure 2.3,11). It is associated with Ditch 2 south of the county road, which itself is not concretely located in this area, and Ditch 2 exhibits no evidence of other bastions. That this configuration of anomalies is a bastion is unlikely.

\section{Mounded Berms}

Soil mounding adjacent to defensive Ditches 1-2 create impressive topographic prominences and robust magnetic anomalies owing to topsoil compositions (several prominent ones are labeled "MB" in Figure 2.3b). These anomalies may be related to mounding elsewhere on the site ("M" in Figure 2.3b), and may have contributed to the village's defenses as ramparts or observation platforms. The mottled nature of these anomalies may point to individual basket 
dumping episodes of magnetically enriched materials as these berms were created. Midden materials may also occur. They tend to be moderately magnetic with measurements typically in the range of 2-5 nT. Palisades associated with the adjacent ditches were probably located along the courses of these anomalies.

\section{Mounds and Mounded Middens}

Several prominent mounds are visible throughout Larson, which are thought to represent mounded midden deposits, but some may be artificial platforms formed for defensive purposes, as occurs at nearby Double Ditch (Kvamme and Ahler 2007). At Double Ditch mounds appear to be sited in concert with fortification ditches, as components of defense, or atop abandoned fortification ditches. Several mounds are labeled in Figure 2.3b and it is clear that the Double Ditch pattern is also present at Larson: several large mounds are indeed situated over filled and buried Fortification Ditch 3, and over portions of Ditch 2 no longer visible on the surface (particularly west of the E410 line, Figure 2.3b). Middens tend to express anomalies through mounding of magnetically enriched topsoil, even more magnetic settlement soils, and burned materials such as sediments from hearth cleanings, fire cracked rock, and ceramics.

Measurements from 8-10 nT are common. One large and elongated mound appears to overlie Ditch 3 (from about N525-N540, Figure 2.3a,b), although the bulk of it may be located behind it (from N510-N525), suggesting its use as a possible rampart, bastion, or observation point linked with village defenses.

\section{Plaza}

A broad, level, and somewhat sunken region immediately outside and adjacent to Ditch 1 is generally regarded as the Mandan plaza (see data from the topographic mapping, below; Figure 2.3). It measures about $45 \mathrm{~m}$ east-west by $25 \mathrm{~m}$ north-south. Magnetic gradiometry supports this identification because it shows this area to be nearly devoid of significant anomalies (Figure 2.15), a circumstance demonstrated at other Mandan sites such as Huff village (32MO11; Kvamme 2003). This lack of anomalies indicates an absence of constructions or modifications to the surface or subsurface, suggesting some sort of ritualized authority while the surrounding area exhibits a very high anomaly density. The exception is the "Ark of the Lone Man," a small-diameter wooden post construction that is visible as a low mound on the surface

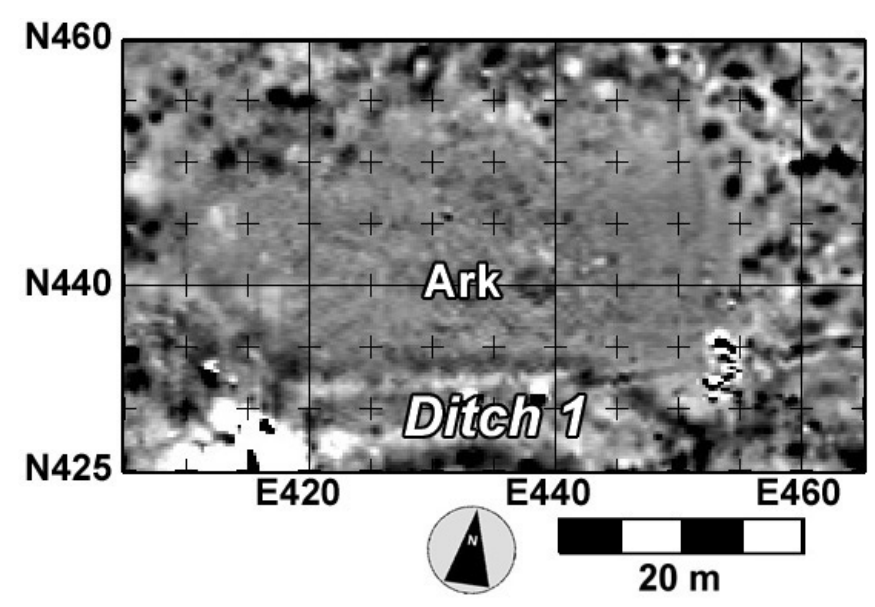

Figure 2.15. Magnetic gradiometry evidence for the Mandan central plaza, with its absence of anomalies (indicating no constructed features) save for a centrally placed one that likely denotes the location of the "Ark of the Lone Man.” 
see topographic mapping, below) and which, consequently, shows moderately increased magnetism owing to thicker topsoil (at E438, N440; Figures 2.3, 2.15).

\section{Houses}

Late Mandan earthlodges were circular while in earlier villages, like Huff (32MO11), they were rectangular in the mid-fifteenth century. No surface or magnetic evidence gives hints of the latter (possibly due to later overbuilding and modification if rectangular forms ever existed at Larson), but ample evidence exists of circular forms. Many large circular anomalies at Larson are of correct size, 12-17 $\mathrm{m}$ in diameter, and likely represent the loci of former earthlodges (Figure 2.3), but some may represent earth-borrowing pits, as occurred extensively at Double Ditch (Kvamme and Ahler 2007). Many of these circular anomalies coincide with circular depressions in the topographic surface, discussed below. A simple formation process model is that soil mounded over a lodge eroded by wind and rain down to its perimeters forming, year after year, an increasingly tall berm, which received its largest and ultimate input after abandonment when most of the sediment found its way to the perimeter. These sediments were, of course, magnetically enriched settlement soils, creating positive magnetic anomalies on top of the raised berms (Bales and Kvamme 2005).

Distinguishing between circular anomalies that might represent the loci of former houses and those that are merely borrow pits can be problematic, but other evidence can be enlisted. First, all houses must posses a centrally located hearth. Other interior anomalies, representing storage pits and auxiliary hearths should also be present. Second, houses should possess a regular circular form, but this need not be the case for borrow pits. That many borrows appear circular in form led Kvamme (2006c) to hypothesize that abandoned circular house depressions were employed as expedient borrow pits.

Virtually certain and likely houses are indicated in Figure 2.3b. Houses classified as "certain” contain validated hearths from the coring program (see Figure 2.5) or are known from previous excavations (Bowers 1940) and are labeled with an " $\mathrm{H}$ " in Figure 2.3b (the lodge excavated by Bowers lies between Ditches 1 and 2, see below). Likely houses are represented by other large circular anomalies of house size that are regular in shape and posses a central anomaly that could derive from a hearth (labeled with an "Ha” in Figure 2.3b). Topographic assessment of surface depression form (see below) was also taken into consideration. The area south of the county road contained too much noise (metal-generated dipolar anomalies) to clearly evaluate. In total, nine houses and five possible houses are defined. They are generally characterized by a surrounding perimeter of positive magnetic anomalies (about 1-2 nT), often discrete and sometimes continuous, hypothesized to derive from eroded lodge roof sediments. Surrounding anomalies of high magnitude (about 2-5 nT), 1-2 m diameter, probably represent exterior subterranean storage pits, a circumstance observed at other sites in the region (e.g., at Huff [Bales and Kvamme 2005] and Double Ditch [Kvamme and Ahler 2007]). Centrally located anomalies 1-2 $\mathrm{m}$ in diameter point to likely hearths (2-9 nT) while surrounding interior anomalies of the same size represent a combination of interior storage pits and auxiliary hearths. 


\section{Borrow Pits}

As discussed in the previous section, borrow pits are surface depressions of large size (usually greater than $15 \mathrm{~m}$ ) that often possess a surrounding raised berm that may express a positive magnetic anomaly. They may be irregular in shape or roughly circular in form. Examples of both occur at Larson (labeled "B" in Figure 2.3b). As was argued at nearby Double Ditch (Kvamme 2006c), it could be the case that the loci of abandoned houses were employed for later borrowing activities, so perfectly circular surface depressions may represent a former house where interior anomalies, floor, and sub-floor deposits were subsequently removed by soil borrowing.

\section{Magnetic Anomalies from Modern Sources}

Numerous anomalies in the area surveyed by magnetic gradiometry are likely derived from modern circumstances, recent land modifications, agriculture, the historic homestead, or through historic archaeological excavations.

- $\quad$ Fence line. A steel post and barbed wire fence crosses the site on its eastern boundary north of the county road, separating it from cultivated lands. Massive dipolar anomalies (exceeding $200 \mathrm{nT}$, the instrument's limit) are associated with each fence post and prohibited survey close to the fence (Figure 2.3).

- Dipolar and monopolar anomalies associated with ferrous metals. Numerous anomalies occur throughout the study area that are unequivocally generated by iron or steel artifacts. They are instantly recognized by a combination of clear dipolar form (seen as adjacent blackwhite pairs), compactness (.5-2 $\mathrm{m}$ in diameter), and high magnitude (5-200 nT). This is particularly true south of the county road in the area of the historic homestead (Figure 2.3 and Figure 2.16a). Most probably represent modern or recent artifacts such as tractor parts, nails, fence staples, barbs, and the like. One long lineation of dipolar anomalies turned out upon probing to be a buried piece of wire (Figure 2.16b). Some dipolar anomalies may represent iron trade artifacts from protohistoric periods of the site's occupation, but it is impossible to predict which. Most of these anomalies vary between -8 to $+15 \mathrm{nT}$, but several exceed $200 \mathrm{nT}$ pointing to massive or linear iron or steel artifacts. Several compact monopolar anomalies may also represent ferrous metal where sources are smaller or deeper (in these cases the weaker negative poles [white] are less visible). They commonly express magnitudes of 3-8 nT. A line of such anomalies that probably represents a string of metal

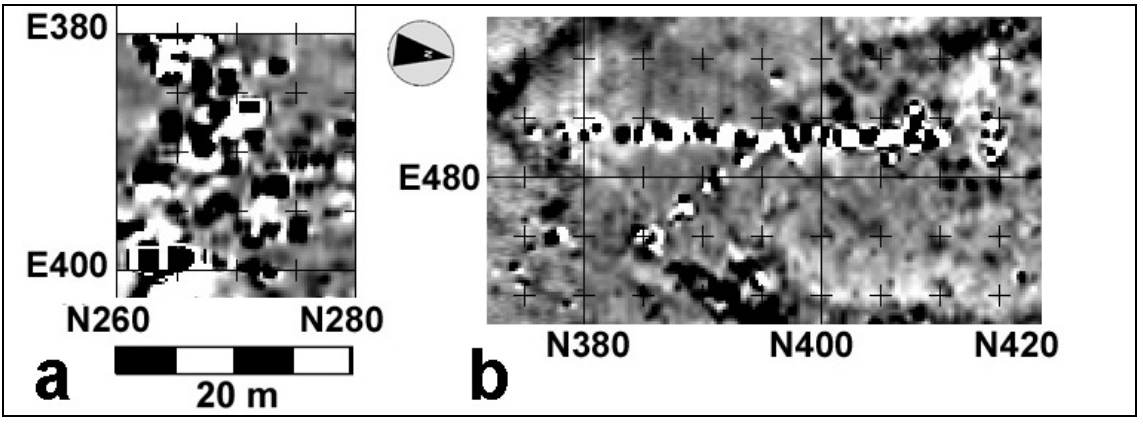

Figure 2.16. Dipolar anomalies resulting from iron or steel artifacts. a) Concentration of ferrous metals near historic homestead. b) A $40 \mathrm{~m}$ long lineation of dipolar anomalies produced by a buried steel wire. 
artifacts dropped along a former path or perhaps debris (e.g., barbs, nails) from a former fence line is illustrated in Figure 2.17).

- Vehicle track. Two parallel linear depressions are visible in the ground surface at the locus of this anomaly (Figure 2.3), undoubtedly representing a recent vehicle track-way. The wheelcaused depressions are associated with negative magnetism ( -1 to $-3 \mathrm{nT})$, most

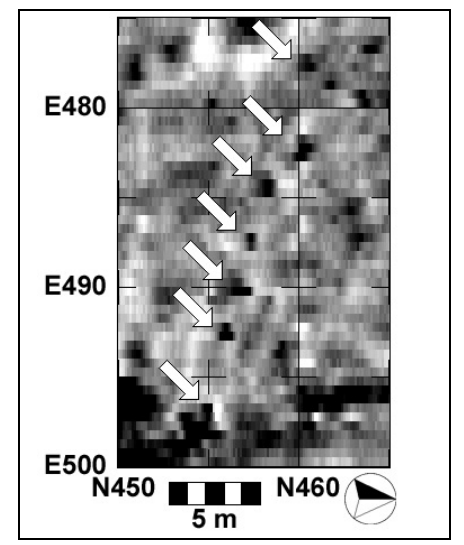

Figure 2.17. Line of monopolar anomalies representing likely iron or steel artifacts by their compact form and high magnetism.

likely because the magnetically enriched topsoil has been pushed to either side, depleting magnetic source material. As a result, the centerline of this two-track is magnetically enhanced owing to the slight mounding of the topsoil, yielding values between .5 to about 3 nT, depending on neighboring parent material (Figure 2.18).

- Looters' holes. Several looters' holes are prominent in Larson's landscape. Most prominent are 3-4 large ones that have removed several cubic meters of matrix. They are easily visualized in a topographic or digital elevation model of the landscape (Figure 2.19a), the creation of which is described in the following section. Not surprisingly, such massive disturbances should leave magnetic anomalies, but this is especially true because each possesses significant ferrous metal artifacts (i.e., rubbish) that

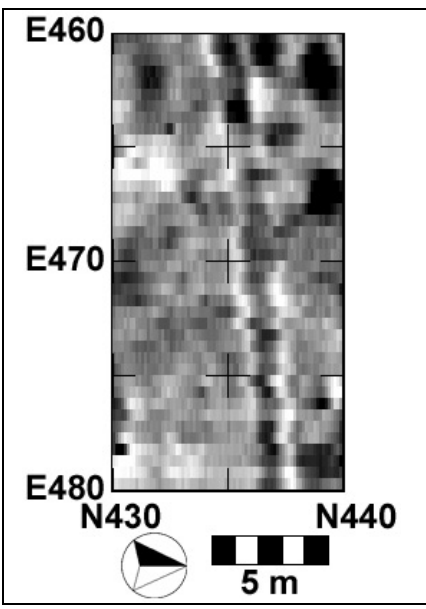

Figure 2.18. Magnetic signature of a vehicle twotrack. generate massive dipolar anomalies (Figure 2.19b). In fact, local lore suggests that an old refrigerator is buried within one of them.

- Bowers' historic excavations. Swenson (2007) summarizes historic archaeological work at Larson, including excavations by Bowers (1940) in 1929. Bowers excavated two middens, designated Works “B” and "D," as well as a lodge and midden mound, designated Work "H." Many archaeological excavations leave steel debris behind-nails or rebar for datums, or broken picks and shovels as part of the backfill. They also greatly disturb the soil, and when backfilled, the natural ordering of soil horizons and strata may not be closely followed. If topsoil is not replaced on top, moderate negative magnetic anomalies may be left at the site of the excavation. Swenson (2007:15) offers a rough map of Bowers' excavations based on his report and that map was used together with the foregoing principles to search for the exact loci of these excavations by seeking appropriate anomalies in the magnetic gradiometry data (Figure 2.3a). The likely locus of Work B is indicated by a 3 x $4 \mathrm{~m}$ zone of low magnetism and several monopolar anomalies that likely point to iron-bearing artifacts within the remnants of a low mound (Figure 2.20a). Work D, on the other hand, exhibits strong negative 


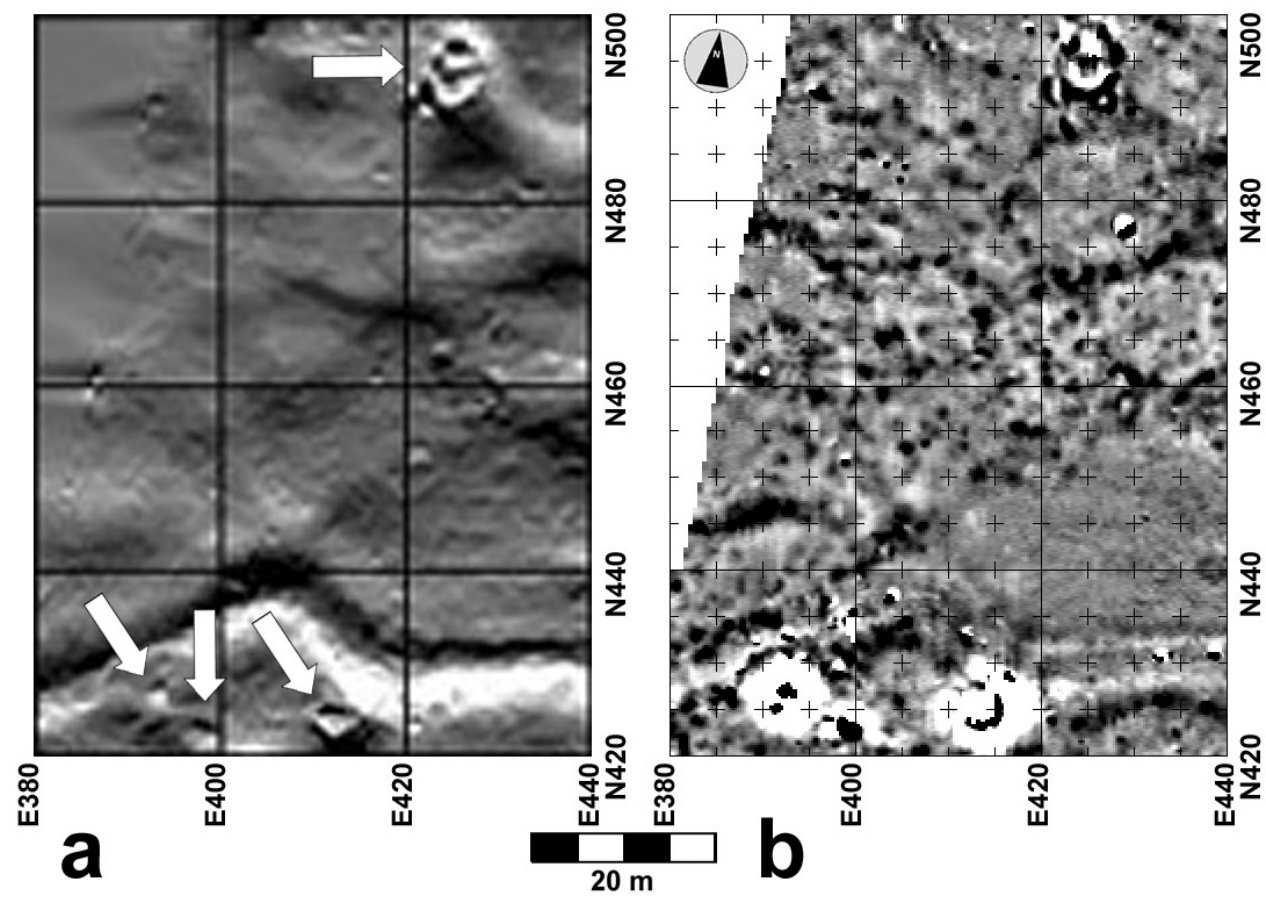

Figure 2.19. Large looters' holes in the surface of Larson can be a) visualized in a digital elevation model of the surface (arrows) which b) leave large dipolar anomalies owing to iron or steel artifacts within them.

magnetism in a rectangular region through and north of a large mound (Figure 2.20b). Work $\mathrm{H}$ was largely conducted within a house depression, which illustrates low magnetism and numerous ferrous metal artifacts in the vicinity (Figure 2.20c).
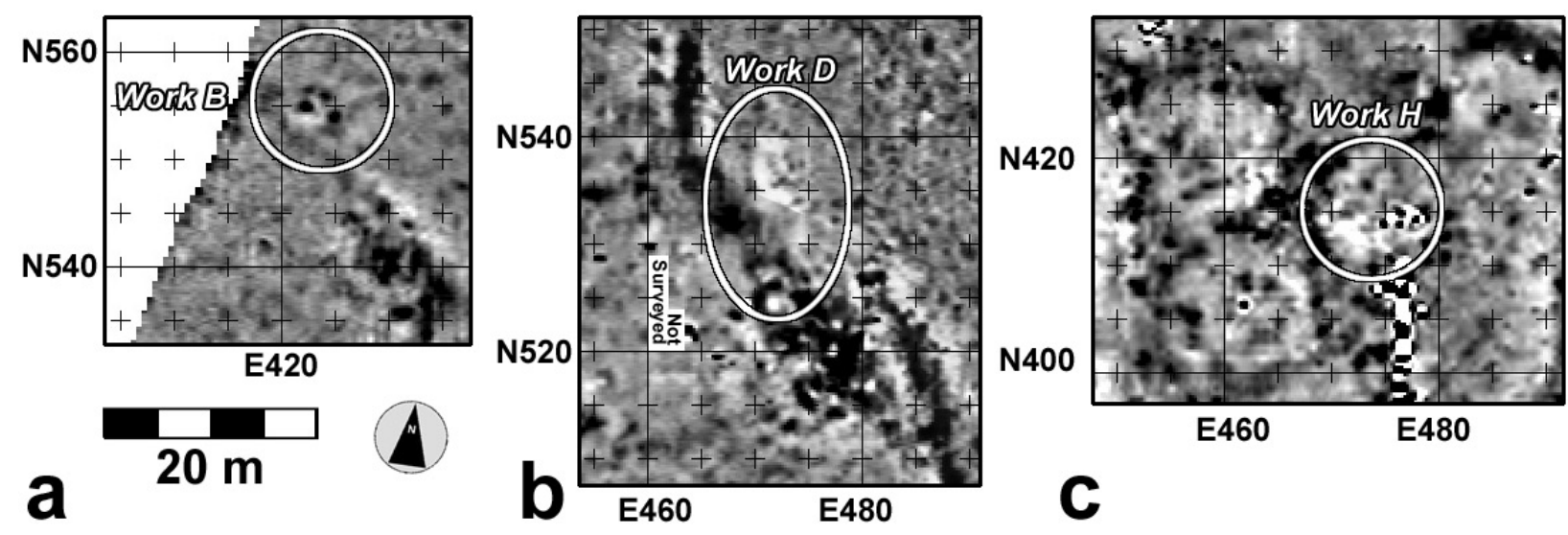

Figure 2.20. Likely sites of Bowers’ 1929 excavations: a) Work B, b) Work D, c) Work H.

- Steps to cultivated area. These anomalies corresponds with $20-30 \mathrm{~cm}$ steps from the higher tall grass region (to the west) adjacent to the lower plowed and cultivated field (to the east). The lower elevation of the cultivated area is caused by settling of sediments through a century of plowing and compression from regular tractor movements, strikingly indicated by the high density of the soil (resistivity electrodes could barely be inserted). The steps and associated berms to the more intact topsoil produce a narrow linear anomaly about $.5 \mathrm{~m}$ wide (Figure 2.21). Unfortunately, the locus of this anomaly overlies the course of portions of what is likely Fortification Ditch 4, adding confusion to the latter's interpretation. 
- Cultivation marks. Clear in the data are two very weak $(<.5 \mathrm{nT})$ arcing anomalies connected with linear components that represent the outer perimeter edges of the effects of large farm equipment, such as plow, disk, or chisel arrays (Figure 2.21). They are caused by slight soil density or mounding variations. These equipment turn-around arcs are probably from recent field preparation or maintenance.

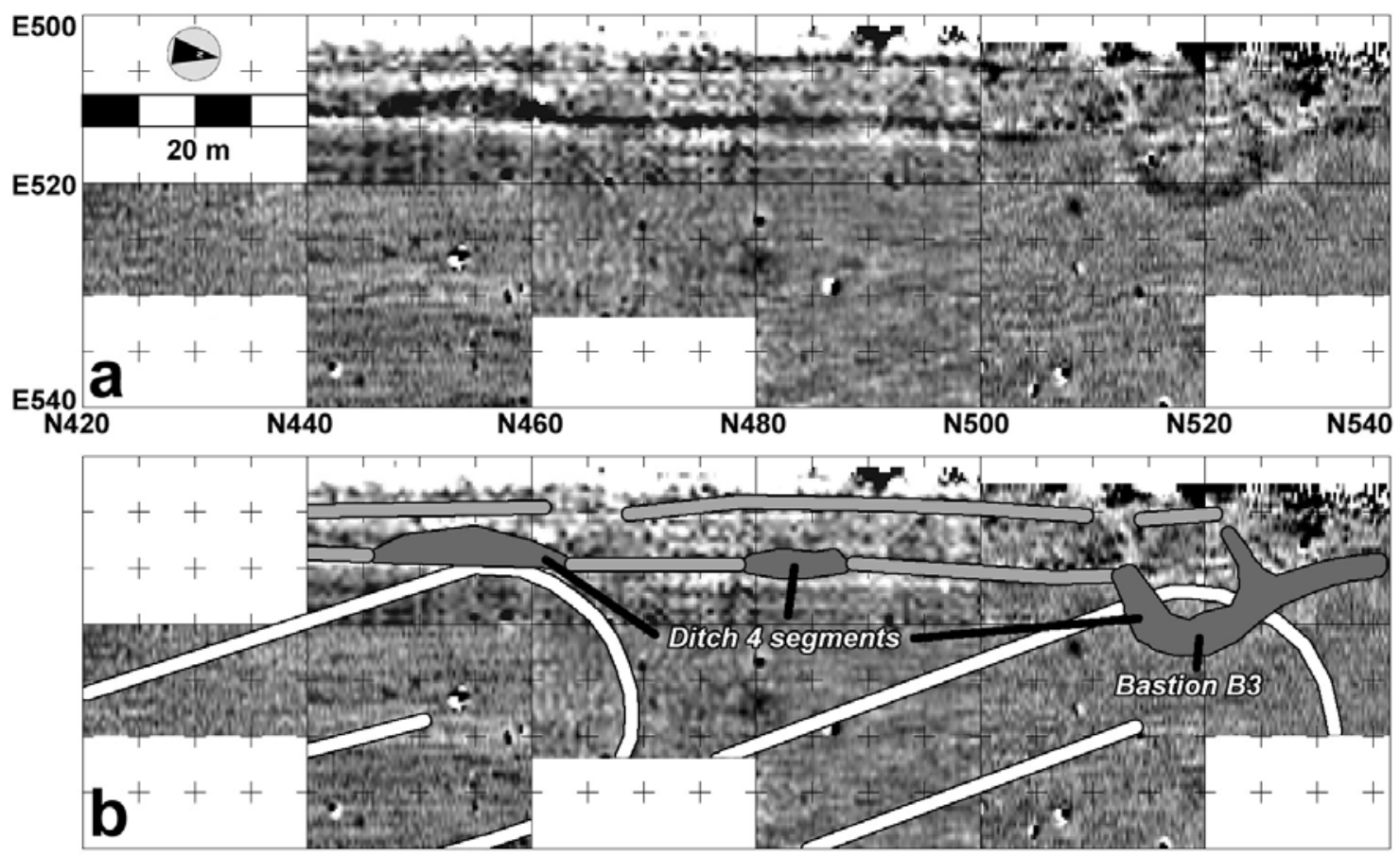

Figure 2.21. Magnetic effects of agricultural practices. a) Raw magnetic data. b) Interpretations with Ditch 4 segments and Bastion B3 (dark gray), steps/boundaries between plowed and intact prairie (light gray), and turnaround arc of chisel or disk array caused by mechanized farming (white).

\section{The Topographic Survey and Creation of a Digital Elevation Model}

Creation of a Digital Elevation Model (DEM) — a model of the ground surface or topography — was a priority in the 2007 field season, with a goal of mapping the entire village area (except areas within agricultural fields). Such a data set would make a record of the state of the site's surface as it existed in 2007 that would serve as a baseline for subsequent change studies resulting from erosion, penned animals (the site is used to graze horses), or vandalism. The data will also be useful for simply visualizing the layout and form of the site. It will also allow more rigorous examination of aspects of the cultural landscape-for instance, size distributions of "house" (earthlodge) or earth borrowing depressions, middens, and mounds. Volumetric possibilities offer additional potential. Finally, it is well known that terrain form holds significant relationships with various types of remote sensing, such as electrical resistivity and aerial thermography. A high-resolution DEM potentially allows study of terrain effects on these data sets.

The creation of a DEM at Larson was accomplished through a relatively new technology known as the robotic total station (Kvamme et al. 2006). Although not as rapid in its coverage as 
aerial laser distance measuring known as LIDAR survey (Barnes 2003), it allows capturing of digital elevation data in a fast-enough way to make DEM creation possible. Moreover, the data are of high accuracy, and superior to LIDAR in this dimension. Although surveyor-grade kinematic Global Positioning Surveys (GPS) represent a popular alternative technology for DEM creation (Chapman and Van de Noort 2001), the robotic total station offers very rapid survey coverage at half the labor costs of a conventional total station, and rivals or surpasses kinematic GPS in accuracy and speed of survey using far less expensive instrumentation.

\section{The Robotic Total Station}

The robotic total station is a relatively new electronic distance measuring (EDM) system with many automated capabilities. The Trimble 5600 contains a highly accurate (sub-centimeter) EDM, a four-speed servo for rapid and accurate aiming, Autolock ${ }^{\mathrm{TM}}$ technology for automatic tracking of the target as it is moved, and robotic capabilities allowing one-person survey through radio linkage (halving crew requirements). The servo-driven aiming, Autolock, and robotic capabilities mean that all operations may be conducted by a single person through a control pad affixed to the reflector rod that is radio-linked to the total station (Figure 2.22). A further innovation that enables a tremendous leap in survey speed is a wheel attached to the base of the reflector rod. This allows the operator to simply roll the rod over the landscape, controlling the survey by radio from the control pad, while the total station automatically tracks the roving rod and records data. For expedient surveys data may be acquired in a continuous mode at a rate of one measurement per second. The $x, y$ (positional), and $z$ (elevation) coordinates in the site's coordinate system are transmitted back to the control pad on the roving unit and displayed in map form in real time (Figure 2.22, middle). At the close of each day's survey, the data are easily

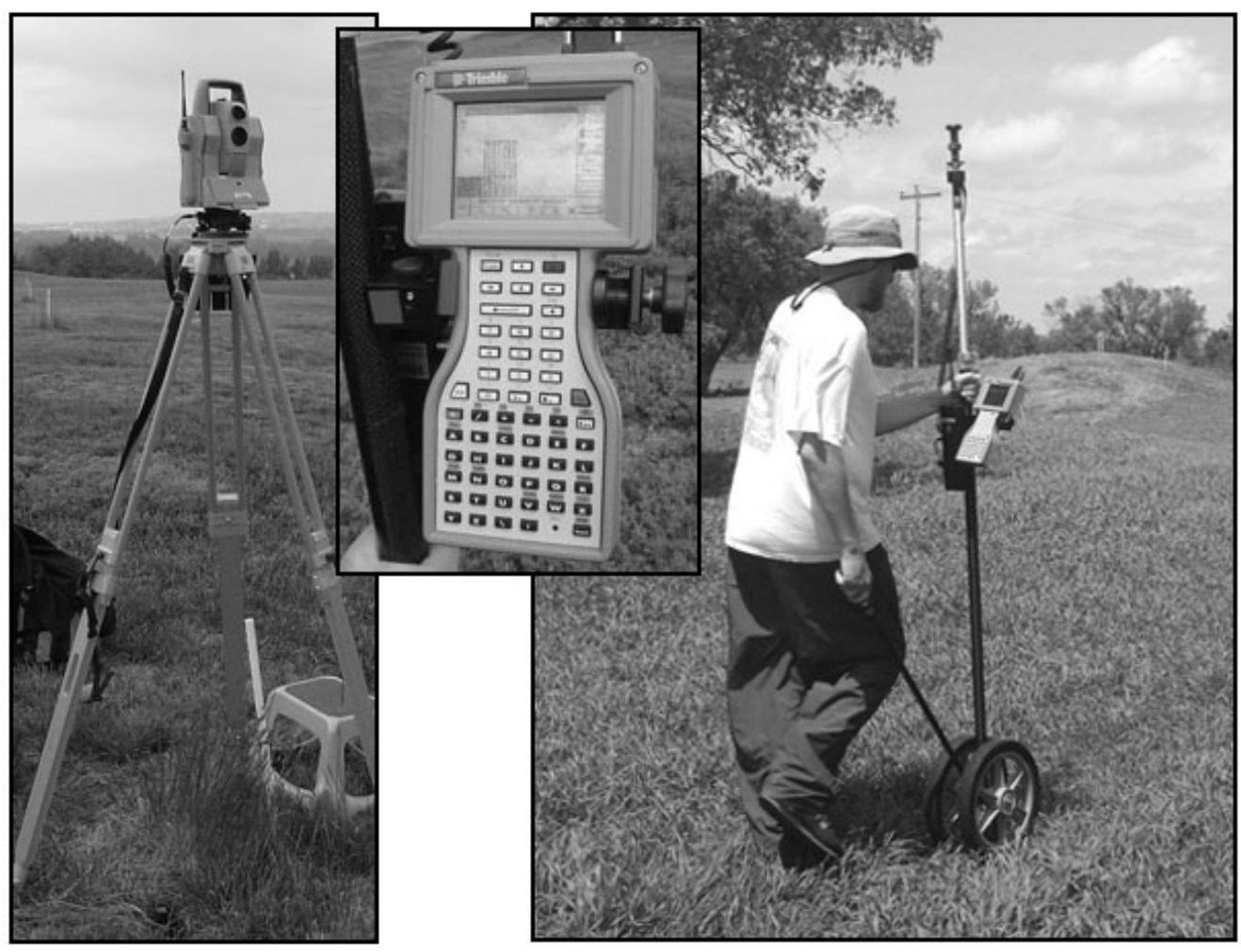

Figure 2.22. The Trimble 5600 robotic total station (left), rodmounted control pad with real-time display (middle), and wheeled reflector rod in use at Larson (right). 
downloaded for computer processing and map creation. The data are represented by comma delimited, $x, y, z$ data triplets in an ASCII format, amenable for input to virtually any mapping program or GIS.

Use of the Trimble 5600 was not without difficulties. Maintaining the rod nearly vertical while it is in motion is a constant problem, but one that experience mitigates. Rod tilting affects the elevation recorded. With the height of the reflector typically set at two meters above the ground surface, if the rod is angled by only $15^{\circ}$ off vertical, horizontal accuracy shifts by more than $.5 \mathrm{~m}$ and vertical accuracy by $.07 \mathrm{~m}$, for example. We believe rod tilting was generally much less in our survey and caused relatively minor errors in the resulting DEM. A more practical problem was obstructions to the laser beam, whether caused by vegetation, landscape variations, or people, which caused the Autolock tracking to be lost, but the signal could be rapidly reacquired and alternate datums ensured survey of all locations despite occasional blockage by vegetation or tall mounds.

\section{Field Methods}

A rapid data collection protocol was utilized at Larson for the Trimble 5600 total station survey. It employed the extant $20 \mathrm{~m}$ square data collection units, previously located by total station for the geophysical surveys, that were marked across the site by one meter long PVC pipes placed vertically in the ground at their corners. By utilizing the $20 \mathrm{~m}$ units, the topographic survey could be conducted piecemeal, unit-by-unit, and all data would be in the site's coordinate system. In each $20 \mathrm{~m}$ unit survey was accomplished by placing pin flags at five-meter intervals at opposite ends of each unit to serve as guides for the survey transects. With an initial sampling density goal of one measurement per meter in both $x$ - and $y$-axes, transects were made approximately every meter by zigzagging through each $20 \mathrm{~m}$ unit and visually estimating approximate transect locations vis-à-vis the pin flags, PVC corner markers, and the real time display on the rod's control unit (Figure 2.22, middle). Within each transect, the wheeled reflector rod was moved at a rate of somewhat less than one meter per second to achieve better than one measurement per meter based on the instrument's continuous mode sampling rate. Transect direction was generally north-south, but east-west transects were also employed in a number of units in order to cross north-south trending fortification ditches at a right angle or to better navigate around impediments. It is emphasized that additional elevation points were also acquired over particularly variable, small, and culturally significant landscape features in each 20 m unit. Approximately 15 minutes were normally required to survey a $20 \mathrm{~m}$ unit, including pin flag setup and the walking of 20 transects. A number of transects were recorded in the area of the county road that bisects the site in order to generate a continuous DEM connecting both site portions. Transects within the road were walked approximately every $5 \mathrm{~m}$, however. All elevations were recorded relative to a site datum, which was assigned an arbitrary elevation of $500 \mathrm{~m}$.

A mapping of the data postings reveals much about the nature of the surveys (Figure 2.23). With data collected continuously, the zigzag surveys in $20 \mathrm{~m}$ collection units caused data points to accumulate at the end of each transect, or when the operator happened to stop midtransect. The few holes visible in the data were caused by the need to avoid open looters' holes 


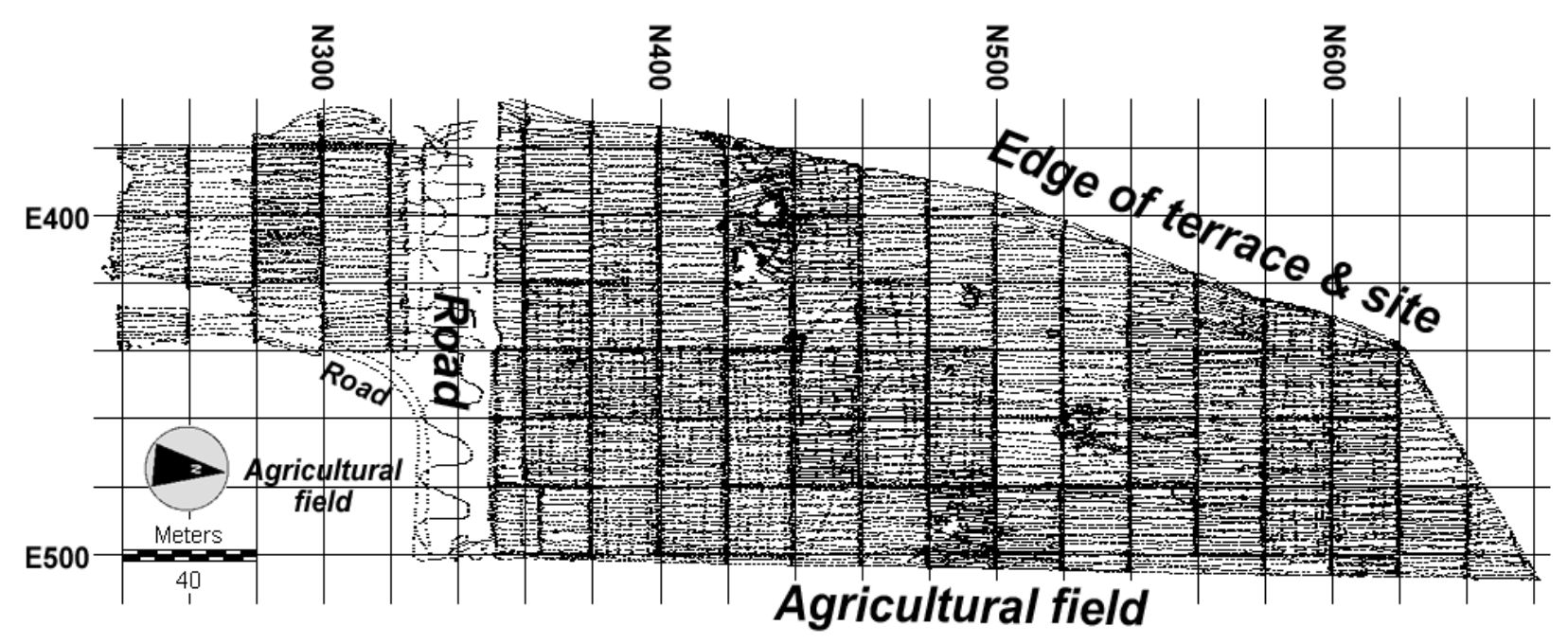

Figure 2.23. Data postings from the robotic total station showing transects and clustering of data points near $20 \mathrm{~m}$ collection unit boundaries, indicated by the background grid. Holes in the point distribution represent the loci of vegetation or large looters' holes while certain data clusters indicate judgmentally placed measurements to enhance details of surface features of interest.

or trees, while some data clustering or additional survey lines point to areas of extraordinary topographic change or of special interest (Figure 2.23).

\section{Data Pre-processing and Creation of Initial DEM}

GIS “point thinning” methods were employed to reduce dense data clusters in the distribution of surveyed points by removing elements closer than a half-meter (otherwise noticeable edge effects occur at $20 \mathrm{~m}$ unit boundaries in the resultant surface from the higher density). This process is illustrated in a data segment in Figure 2.24a,b. A TIN model of triangular polygons was then generated based on a Delauney Triangulation between the redefined vertices (Figure 2.24c). Each triangular facet in the three-dimension surface represents a plane between three points of elevation. With "point" elevations recorded at the bottom of each house or basin depression, a TIN model ensures real cavities in the resulting surface, unlike many other surface-generating techniques (Burrough and McDonnell 1998).

The TIN model was then used to generate a raster DEM with systematically distributed elevations. In this process, point-slope methods are employed to interpolate elevation values systematically, every $50 \mathrm{~cm}$, across each triangular facet, based on the known corner elevations of the facets (Burrough and McDonnell 1998). Using the TIN surface an initial raster DEM was created for the entire site, measuring $160 \mathrm{~m}$ east-west by $460 \mathrm{~m}$ north-south $\left(73,600 \mathrm{~m}^{2}\right.$ or 7.36 ha). Background elevations outside of the area actually surveyed within this 160 x $460 \mathrm{~m}$ study area rectangle were assigned an elevation of $507 \mathrm{~m}$, which most closely matched the arbitrary base elevation of the village area. The horizontal spatial resolution of the DEM is a half-meter with vertical accuracy within about a centimeter. 


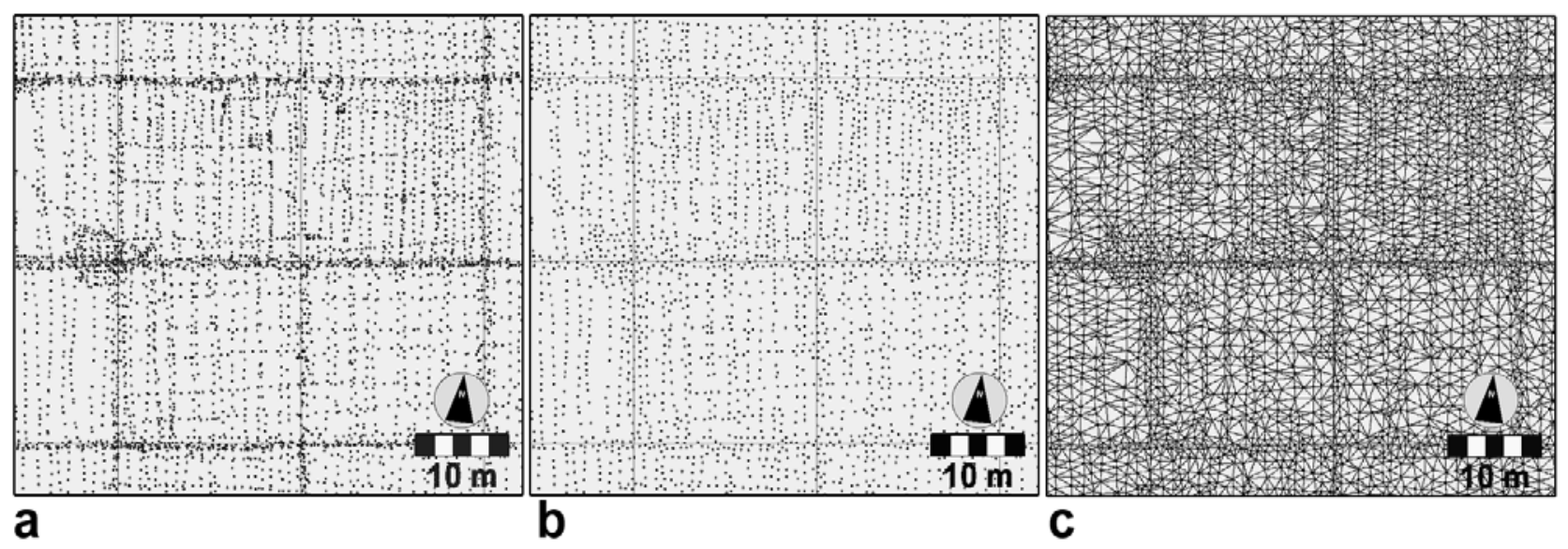

Figure 2.24. Point thinning and TIN creation in the robotic total station data. a) Original data distribution obtained from the survey. b) Thinned distribution with all points separated by a half-meter or more. c) Delauney triangulation of a TIN model developed from the thinned data.

\section{DEM Post-processing}

Although the initial DEM produced from the robotic total station data showed excellent detail, further analysis indicated it contained minor defects in the form of striping, an unavoidable result from low-level tilting of the reflector rod during the survey. With zigzag methods of survey, transects in one direction may be shifted a few centimeters compared to transects collected in the reverse direction, causing minor data shifts which manifest themselves as stripes. This defect is revealed only under low light-angle shadowing, however (circled areas in Figure 2.25a). In truth, without shading they probably cannot be detected and could be left in place.

An algorithm by Oimoen (2000) was specifically developed to reduce striping that commonly occurs in U.S. Geological Survey Level 1 DEMs. It was applied to remove striping artifacts in the Larson DEM. This algorithm includes three steps.

(1) It applies a low-pass (averaging) filter down rows in the direction of striping. The length of the filter is the approximate stripe length. This tactic characterizes the elevation trend of stripes within rows.

(2) A high-pass filter, a single column wide, is then passed over this result at a right angle, emphasizing relative differences in elevation between adjacent rows. These differences represent the elevation defect causing the striping.

(3) The result in \#2 is then subtracted from the original DEM to eliminate striping variations.

Stripes isolated by this algorithm are illustrated for the example data set in Figure 2.25b. Subtraction of these stripes from the original DEM (Figure 2.25a) yields a corrected and stripefree final result (Figure 2.25c).

It is again emphasized that the magnitude of the striping artifacts in the initial DEM is exceedingly small. This is illustrated by basic statistics and a histogram of the isolated stripes in 
the example DEM segment (Figure 2.25d). The standard deviation of these normally distributed errors is only $3 \mathrm{~mm}$, meaning that 99 percent of the striping errors (i.e., +/- 3 s.d.) are less than a centimeter in magnitude!

\section{Final Site-wide DEM}

The final site-wide DEM can be used to illustrate the topographic surface of Larson in a variety of ways, including shaded relief maps, three-dimensional views, and contour maps with high contour density (e.g., $10 \mathrm{~cm}$ contour intervals). Each gives different insights. Shaded relief maps are illustrated in Figure 2.26, with shading given from several directions. Remarkable details are obvious in each (basic interpretations are given in Figure 2.26d). Prominent Ditch 1, portions of Ditch 2, house or borrow pit depressions, and large mounds are obvious, as are the

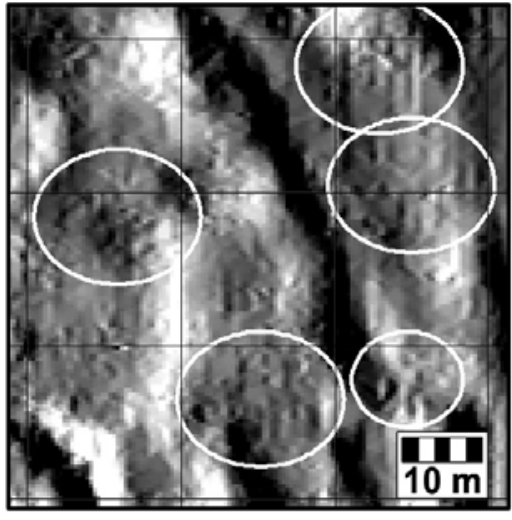

a

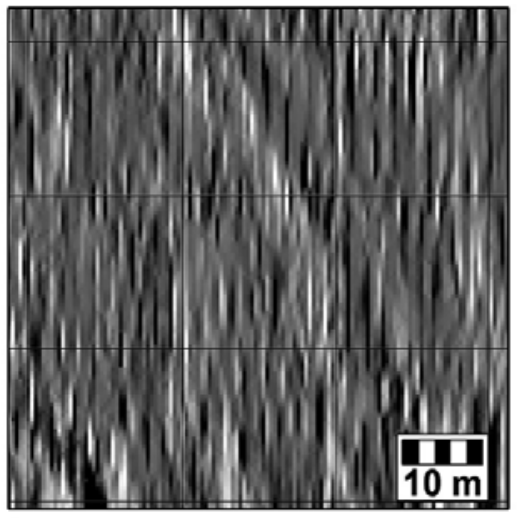

b

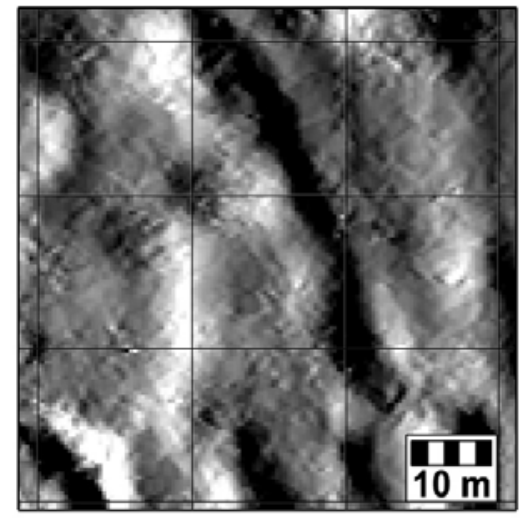

C

Summary Statistics
\begin{tabular}{|l|l|l|l|l|l|}
\hline Class width & Mean & Actual min & Actual max & N & Std deviation \\
\hline 0.001 & 0 & -0.108 & 0.108 & 276529 & 0.003 \\
\hline
\end{tabular}

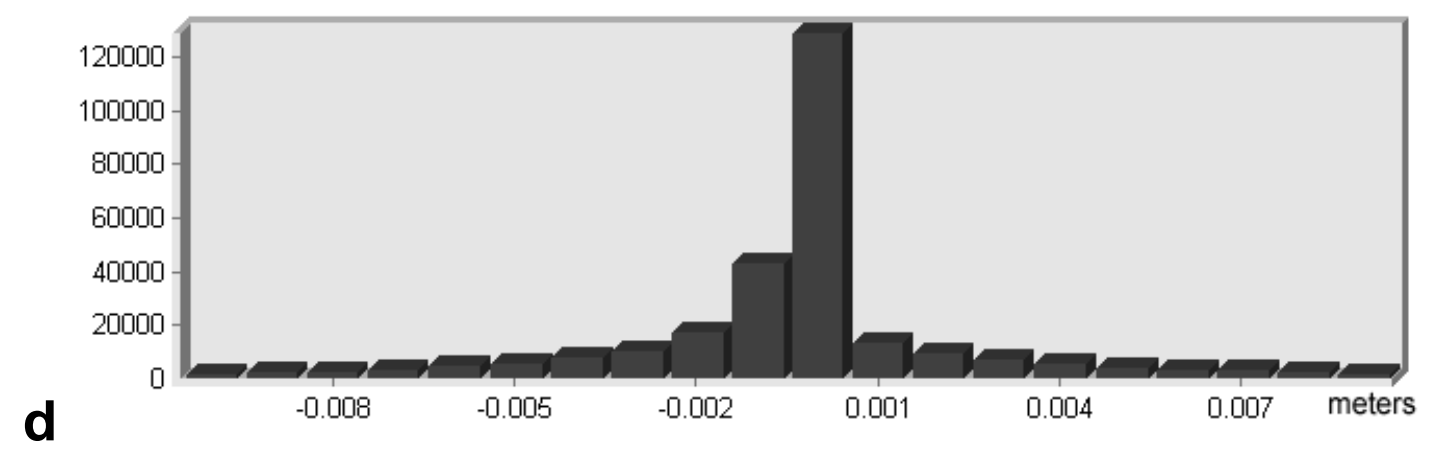

Figure 2.25. Removal of subtle striping in the DEM. a) Shaded initial DEM surface (from left) illustrating striping artifacts (circled). b) Stripes isolated by the Oimoen (2000) algorithm. c) Final DEM after subtraction of stripes (b) from the initial DEM (a). d) Statistics and histogram illustrating the low magnitude of the striping defect.

roads and terrace edge. The prominence of various surface depressions is obvious north of the county road, but depressions are extremely subtle south of the road, undoubtedly due to the effects of plowing and probable land leveling during the homestead period. What is believed to be the Central Plaza of the village stands out and, within it, a low mound that purportedly 


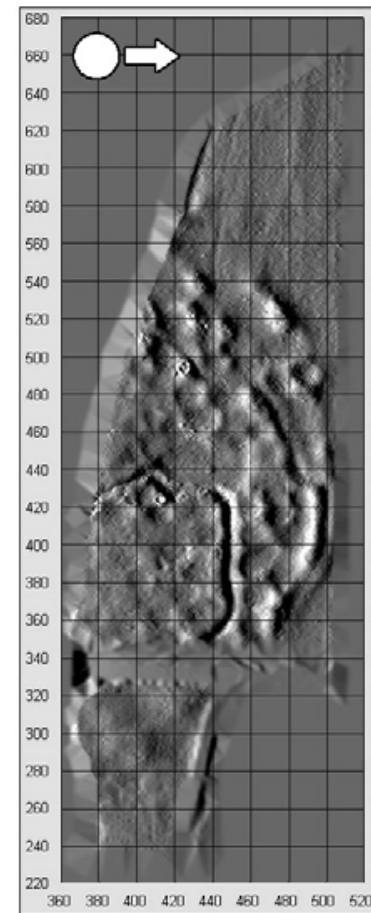

a

Figure 2.26. Shaded relief views of Larson surface topography computed from the DEM. a) Shading from the west. b) Shading from the northwest. c) Shading from the north. d) Principal interpretations.

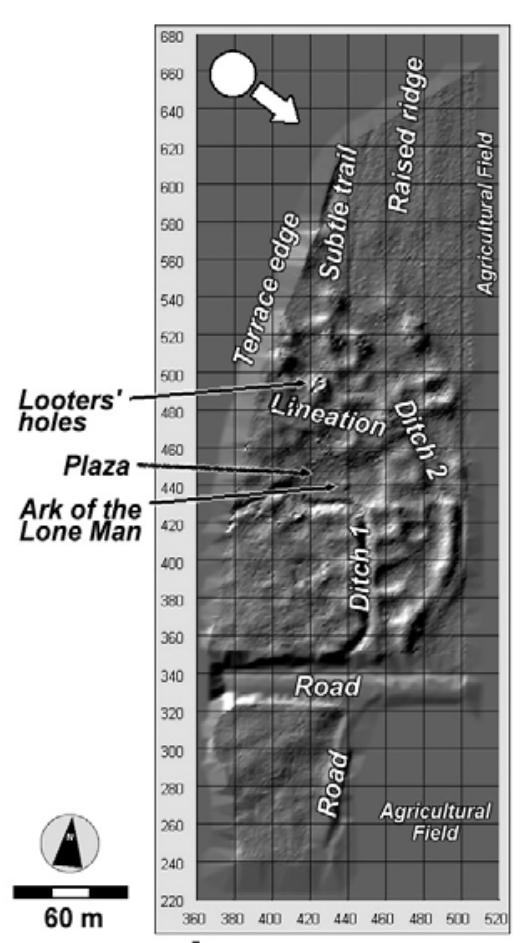

d

represents the "Ark of the Lone Man," a Mandan cultural construction. A number of minor features may also be discerned. Among there are larger looters' holes. A pronounced linear depression in the landscape, several meters wide, probably represents a trail (possibly prehistoric) immediately north of the village, particularly visible in the west-shaded map (Figure 2.26a). A subtle raised ridge only a few decimeters in height is also apparent north of the village (with function and origin unknown) and another robust lineation crosses the site from west-toeast (best seen in the north-shaded map, Figure 2.26c), probably a post-occupation trail.

An enlarged view of the modeled topographic surface reveals these features in greater detail in north, central portions, and the southern area of the site (Figure 2.27).

The DEM actually represents a three-dimensional model of Larson's surface and, consequently, can be displayed with three-dimensional graphics software to give realistic views of the topography that may yield even greater insights (Figure 2.28a,b). Moreover, the data can be subjected to high-density contouring to produce contour maps for field use and other purposes (Figure 2.28c). Figure 2.31 includes a detailed contour map of the entire site.

\section{Data Integration}

The topographic surface represented by the DEM is an excellent source of information about Larson Village because it portrays so many significant elements of this ancient site, 

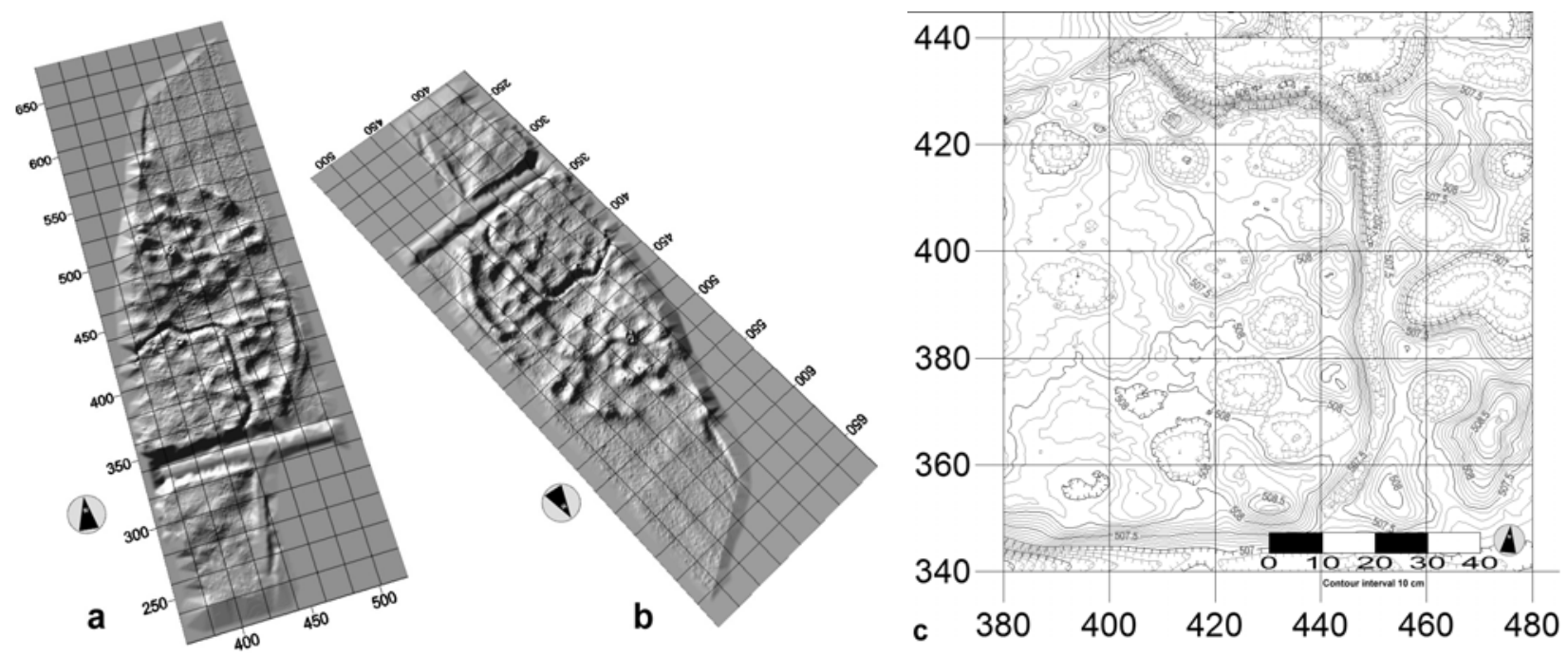

Figure 2.27. Other representations of the Larson DEM. a, b) Three-dimensional views. c) Contour map of site segment with a $10 \mathrm{~cm}$ contour interval.
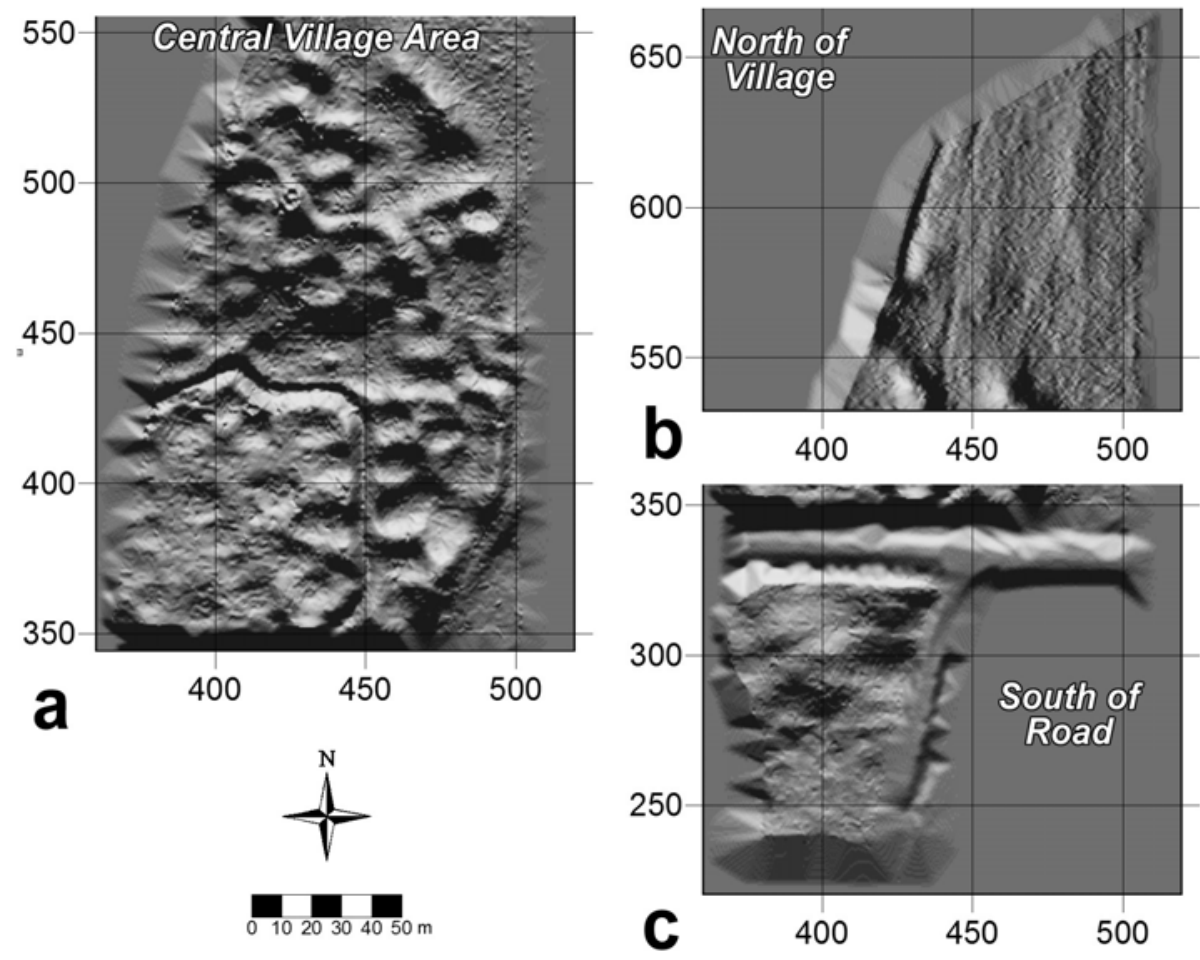

Figure 2.28. Enlarged close-up views of Larson's topographic surface as revealed by the DEM. a) Central village area. b) Area north of village. c) Area south of road.

including house and borrow pit depressions, fortification ditches, and mounds. These data can therefore be combined, through computer graphics, with the results of the magnetic gradiometry survey to provide even greater insights. This is illustrated in Figure 2.29a where nearly the entire study area is portrayed, viewed from the west-southwest at high altitude. The DEM adds the third dimension of elevation, making ditches and depressions stand out. The main village core, plaza, and other elements are readily apparent. This technique does not just create an unusual graphic, but generates imagery that enhances interpretation. 
A more detailed close-up view in Figure 2.29b illustrates many significant relationships between Larson's topography and its magnetic anomalies that aid interpretation. For instance, pronounced magnetic anomalies often are centrally located within large circular depressions, suggesting that the depressions may represent former houses and that the anomalies may derive from hearths (horizontal arrows, near bottom). This, in fact, is the case with the two indicated anomalies. Additionally, throughout the magnetic overlay major areas of mounding generally appear strongly magnetic, which points to the practice of mounding settlement soils adjacent to houses or ditches (diagonal arrows, Figure 2.29b). This may also result from a natural process that occurred after an earthlodge was abandoned, where eroded roof sediments were likely deposited around the perimeter forming a magnetic "ring” (see Bales and Kvamme 2005). Finally, the three-dimensional view clearly illustrates the basin shape and extent of the central plaza (area around cross) and its complete lack of magnetic anomalies, a circumstance seen at other Mandan sites such as Huff Village (32MO11), suggesting a prohibition against constructions in this area (Kvamme 2003). As noted earlier, the DEM possesses sufficient resolution to portray the low mound associated with the purported "Ark of the Lone Man"

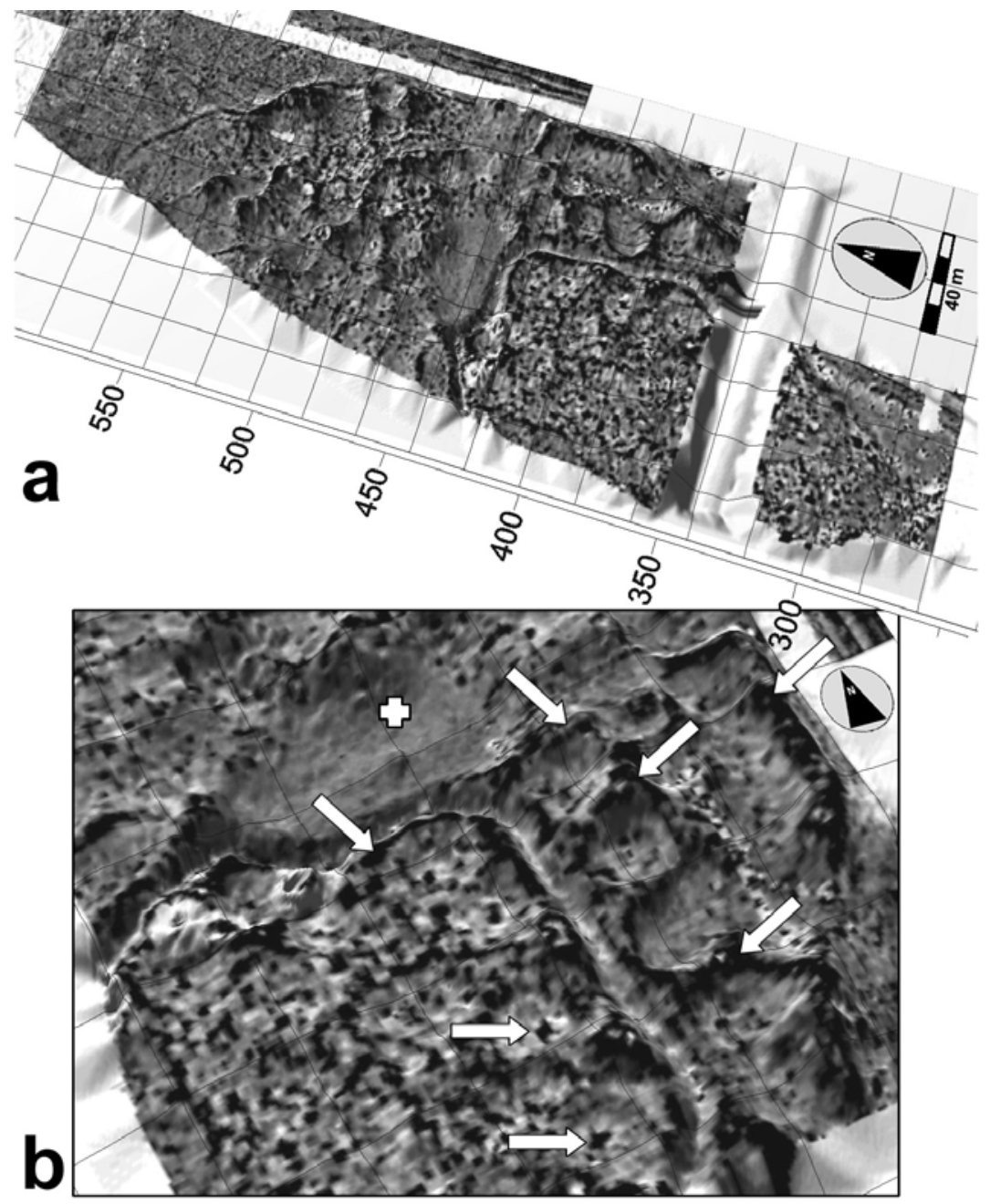

Figure 2.29. Three-dimensional magnetic overlays on the DEM. a) Site-wide view to east. b) Zoomed view to northeast showing significant relationships between magnetic anomalies and topography. 
(immediately below the cross), which illustrates mildly raised magnetism, probably from the soil mounding itself.

\section{Conclusions}

Magnetic gradiometry surveys at Larson Village in 2007 successfully completed the survey initiated in 2006 by covering the entire remaining intact portion of the village. Multiple classes of anomalies of archaeological interest were located and defined. In addition to two inner fortification ditches visible on the surface, two buried outer ditches are identified. Three Ushaped bastions associated with Ditches 3 or 4 are also revealed (one by the 2006 electrical resistance survey where a steel fence obscured the magnetometry). Massive mounding appears to occur over or adjacent to Ditch 3, a circumstance seen at nearby Double Ditch and interpreted as a defensive measure (Kvamme and Ahler 2007). Numerous subterranean storage pits are also located. In combination with the evidence of surface depressions, perhaps as many as 14 houses are defined with anomalies that indicate centrally placed hearths, surrounding storage pits, and auxiliary hearths. A level space commonly viewed as the village plaza gains supporting evidence from the gradiometry survey because no anomalies are indicated, agreeing with the situation learned in the plaza at Huff Village (32MO11; Kvamme 2003). It is of interest that three of Bowers' (1940) excavations appear to be indicated by anomalies of appropriate type that coincide with maps of their approximate location. The accuracy of the geophysical surveys was such that archaeological excavations in 2006 and a coring program in 2007 could be accurately targeted over features of interest. These activities confirmed the accuracy of the geophysical surveys. The coring data on large samples of pits and hearth also permitted analyses and comparisons of their magnetism. It is shown that deeper storage pits are more magnetic than shallow ones, that pits in the village core exhibit greater magnetism than those in the periphery, and that, overall, hearths are significantly more magnetic than storage pits, except pits within the village core appear to be equally magnetic.

The 2007 fieldwork also saw the complete topographic survey of the intact village area, with sub-meter spatial resolution and vertical accuracy to approximately a centimeter. This mapping was accomplished by robotic total station. GIS methods were employed to generate a DEM of the site's surface with half-meter spatial resolution. This model of 7.36 ha contains great detail that illustrates houses, borrow pits, and ditch depressions, as well as large and small mounds and even looters' holes. When magnetic gradiometry results are overlaid on the DEM a powerful visualization tool is achieved that simultaneously portrays landform and magnetic evidence for a fuller understanding of archaeological features at Larson.

\section{Acknowledgements}

This research was conducted under a grant from the PaleoCultural Research Group (PCRG) of Flagstaff, Arizona, made possible by the funding provided by the State Historical Society of North Dakota (SHSND). Fern E. Swenson, Director of the Historic Preservation Division of the SHSND, and Mark D. Mitchell, project Principal Investigator of PCRG, were 
incredibly supportive of this work. SHSND archaeologist Tim Reed provided logistical support including site gridding by total station. The FM-256 was provided by the Archeo-Imaging Lab and the Trimble 5600 by the Center for Advanced Spatial Technologies of the University of Arkansas. The Bartington 601 was graciously loaned by Archaeo-Geophysical Associates of Austin, Texas. Duncan McKinnon, graduate student in the Department of Anthropology, University of Arkansas, greatly aided this work as a field assistant. 


\section{References Cited}

Bales, Jennifer R., and Kenneth L. Kvamme (2005). Geophysical Signatures of Earthlodges in the Dakotas, In Plains Earthlodges: Ethnographic and Archaeological Perspectives, D.C. Roper and E.P. Pauls, eds., University of Alabama Press, Tuscaloosa, pp. 157-183.

Barnes, I. (2003). Aerial remote-sensing techniques used in the management of archaeological monuments on the British Army’s Salisbury Plain training area, Wiltshire, UK.

Archaeological Prospection 10:83-90.

Burrough, P.A., and R.A. McDonnell (1998). Principles of Geographical Information Systems. Oxford University Press, Oxford.

Bowers, Alfred W. (1940). Missouri River Earthlodge Archaeology of North Dakota and South Dakota. Manuscript on file at Logan Museum, Beloit College, Wisconsin.

Chapman, H.P., and R. Van de Noort (2001). High-resolution wetland prospection, using GPS and GIS: landscape studies at Sutton Common (South Yorkshire), and Meare Village East (Somerset). Journal of Archaeological Science 28:365-375.

Clark, Anthony (2000). Seeing Beneath The Soil: Prospection Methods In Archaeology.

Reprinted. Routledge, London. Originally Published 1990, B.T. Batsford Ltd., London.

Kvamme, Kenneth L. (2003). Multidimensional Prospecting in North American Great Plains Village Sites. Archaeological Prospection 10:131-142.

Kvamme, Kenneth L. (2006a). Report of Geophysical Investigations at the Larson Site (32BL9), North Dakota. Submitted to State Historical Society of North Dakota, Bismarck.

Kvamme, Kenneth L. (2006b). Magnetometry: nature’s gift to archaeology. In Remote Sensing in Archaeology: An Explicitly North American Perspective, edited by Jay K. Johnson, pp. 205-233. University of Alabama Press, Tuscaloosa.

Kvamme, Kenneth L. (2006c). Final Report: Four Years of Geophysics and Remote Sensing at the Double Ditch State Historic Site, 2001-2004. Submitted to State Historical Society of North Dakota, Bismarck.

Kvamme, Kenneth L. and Stanley A. Ahler (2007). Integrated Remote Sensing and Excavation at the Double Ditch State Historic Site, North Dakota. American Antiquity 72(3):539-561.

Kvamme, Kenneth L., Eileen G. Ernenwein, and Christine J. Markussen (2006). Robotic total station for microtopographic mapping: an example from the Northern Great Plains. Archaeological Prospection 13:91-102.

Oimoen, M.J. (2000). An effective filter for removal of production artifacts in U.S. Geological Survey 7.5-minute Digital Elevation Models. Proceedings of the Fourteenth International Conference on Applied Geologic Remote Sensing, pp. 311-319. Las Vegas, Nevada. Veridian ERIM International, Ann Arbor, Michigan.

Mitchell, Mark D. (2007). Analytic Units and Collection Chronology. In Geophysical Survey and Test Excavations During 2006 at Larson Village, Burleigh County, North Dakota, Mark D. Mitchell, ed., pp. 93-105. Report by PaleoCultural Research Group submitted to the State Historical Society of North Dakota.

Swenson, Fern E. (2007). Previous Investigations at Larson Village. In Geophysical Survey and Test Excavations During 2006 at Larson Village, Burleigh County, North Dakota, Mark D. Mitchell, ed., pp. 11-25. Report by PaleoCultural Research Group submitted to the State Historical Society of North Dakota. 


\section{Coring Data for Hearths and Pits}

Table 2.2. Hearth data from PCRG coring program.

\begin{tabular}{lcccc}
\hline Core ID & Hearth Type & Easting & Northing & Maximum nT \\
\hline 108 & Hearth & 418 & 396 & 4.12 \\
110 & Hearth & 432 & 418 & 11.97 \\
133 & Hearth & 404 & 426 & 6.96 \\
100 & Hearth & 372 & 371 & 8.46 \\
109 & Hearth & 437 & 406 & 7.06 \\
51 & Hearth over Pit & 384 & 316 & 11.87 \\
213,214 & Hearth over Pit & 432 & 365 & 7.35 \\
218,219 & Hearth over Pit & 434 & 384 & 7.87 \\
\hline
\end{tabular}

Table 2.3. Pit data from PCRG coring program.

\begin{tabular}{|c|c|c|c|c|c|}
\hline Core ID & Easting & Northing & Depth $^{1}$ & Maximum nT & Location $^{2}$ \\
\hline 19,20 & 486.5 & 560 & 100 & 1.03 & Outside \\
\hline $21,22,23$ & 474 & 574 & 119 & 3.34 & Outside \\
\hline 25 & 476 & 566 & 112 & 2.4 & Outside \\
\hline 45 & 476.4 & 572.5 & 117 & 1.1 & Outside \\
\hline 49 & 522 & 488.3 & 92 & 1.95 & Outside \\
\hline 50 & 379.5 & 374 & 139 & 3.38 & Core \\
\hline 52 & 390 & 317.5 & 170 & 6.58 & Core \\
\hline 102 & 373 & 380 & 111 & 6.23 & Core \\
\hline 103 & 377.5 & 361.5 & 168 & 5.03 & Core \\
\hline 104 & 375 & 395 & 124 & 5.78 & Core \\
\hline 107 & 399.5 & 381.5 & 170 & 7.28 & Core \\
\hline 111 & 418 & 419 & 142 & 6.55 & Core \\
\hline 113 & 411.5 & 417.5 & 134 & 2.86 & Core \\
\hline 114 & 389 & 418 & 91 & 5.43 & Core \\
\hline 117 & 389.5 & 412.5 & 148 & 9 & Core \\
\hline 118 & 395.5 & 388.5 & 111 & 7.15 & Core \\
\hline 119 & 397 & 381 & 203 & 10.62 & Core \\
\hline 121 & 462 & 408 & 152 & 4.62 & Mid-zone \\
\hline 122 & 460 & 405 & 108 & 1.79 & Mid-zone \\
\hline 126 & 476 & 418 & 126 & 2.09 & Mid-zone \\
\hline 127 & 457.5 & 420 & 185 & 2.83 & Mid-zone \\
\hline 128 & 485 & 423.5 & 102 & 5.38 & Mid-zone \\
\hline 129 & 486 & 424.5 & 113 & 6.64 & Mid-zone \\
\hline 134 & 450 & 476.5 & 162 & 4.06 & Mid-zone \\
\hline 135 & 447.5 & 479 & 155 & 3.22 & Mid-zone \\
\hline 137 & 416.2 & 499.5 & 134 & 1.8 & Mid-zone \\
\hline 138 & 387 & 316 & 205 & 13.92 & Core \\
\hline 204 & 392.5 & 355.5 & 210 & 5.99 & Core \\
\hline 205 & 393.5 & 356 & 85 & 3.57 & Core \\
\hline 215 & 433.7 & 366 & 133 & 9.76 & Core \\
\hline 216 & 426.5 & 374 & 172 & 6.85 & Core \\
\hline 217 & 427 & 373 & 115 & 3.9 & Core \\
\hline 220 & 431 & 386.5 & 147 & 12.14 & Core \\
\hline 236,237 & 405.5 & 453 & 93 & 6.75 & Mid-zone \\
\hline 238 & 407 & 466 & 190 & 3.73 & Mid-zone \\
\hline
\end{tabular}

${ }^{1}$ Depths to base of pit; depths averaged for multiple Core IDs. ${ }^{2}$ Core=village core inside Ditch 1; Mid-zone=between Ditches 1 \& 2; Outside=outside of village or Ditch 4. 


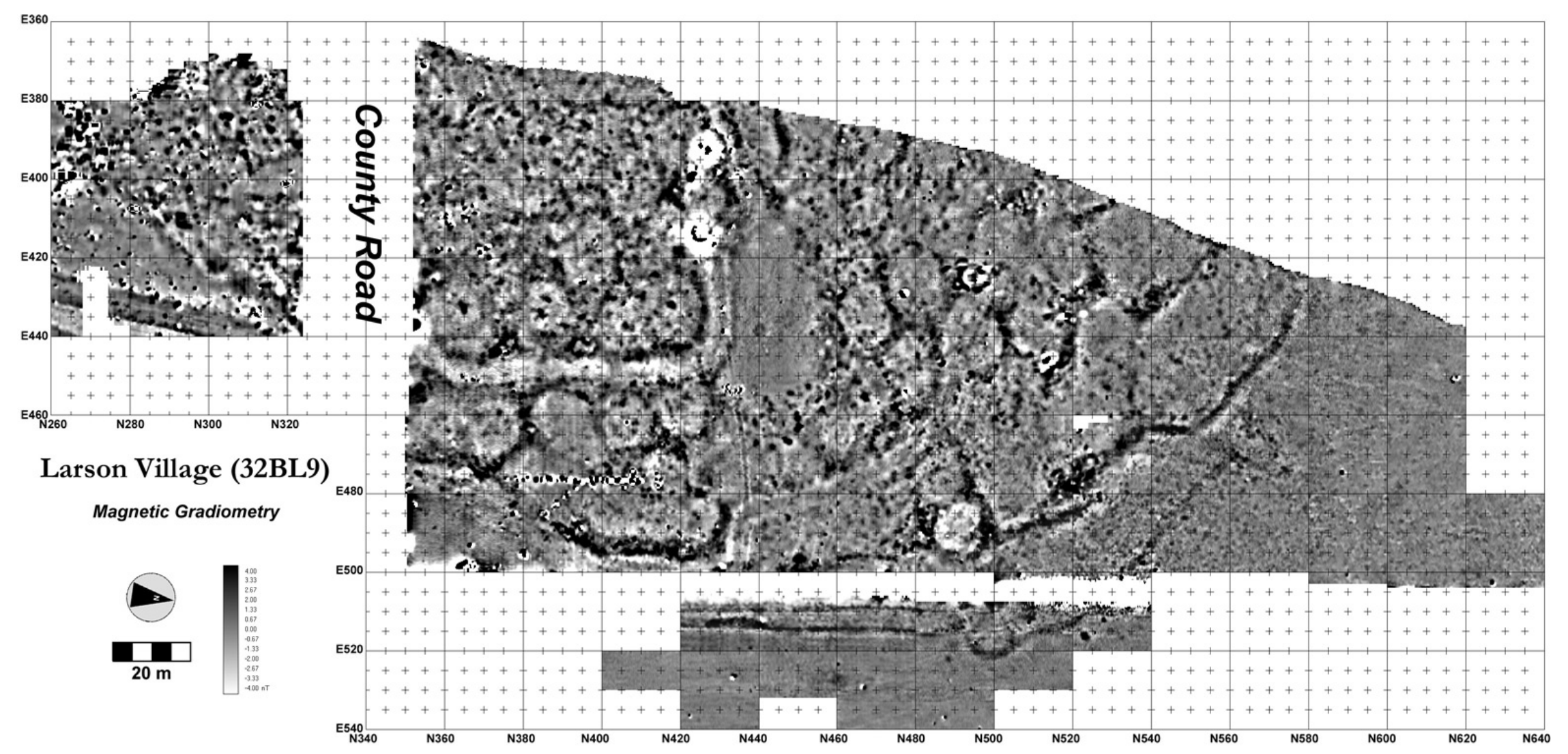

Figure 2.30. Larson Village (32BL9) magnetic gradiometry survey. 


\section{Larson (32BL9)}

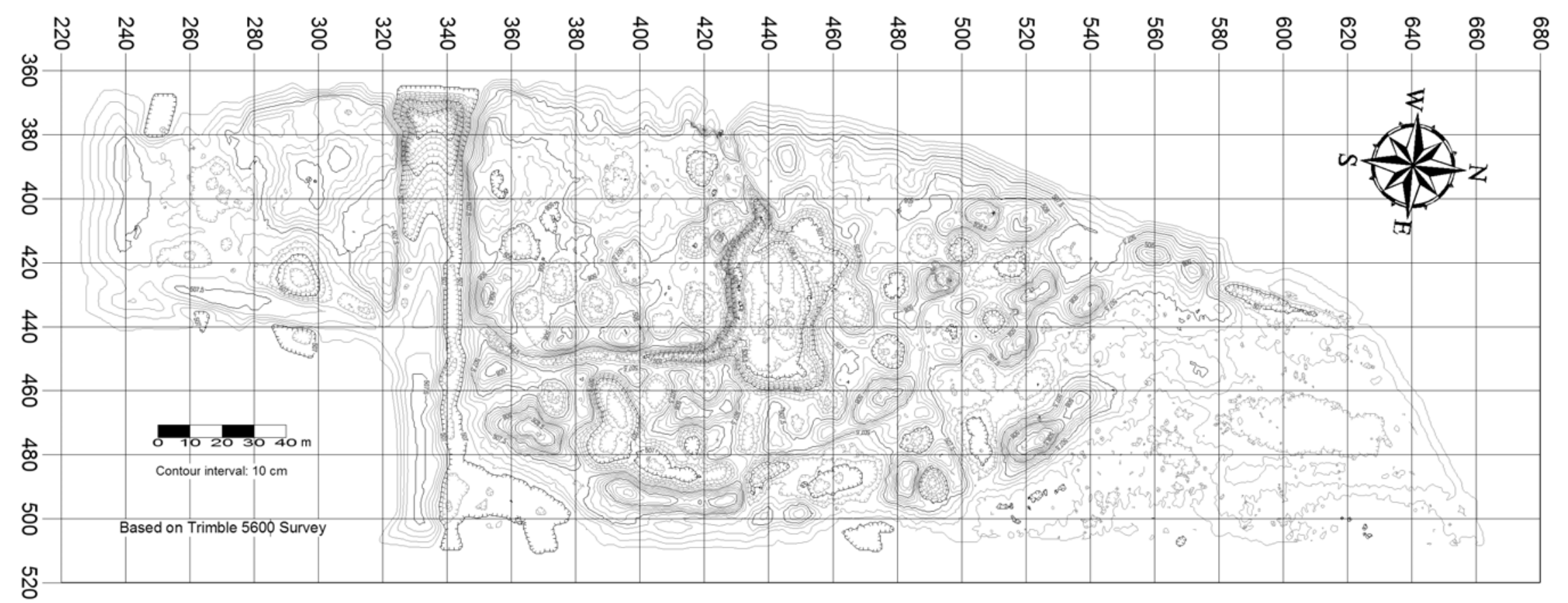

Figure 2.31. Contour map of Larson Village (32BL9) produced from the robotic total station survey. 


\title{
3. Coring Results
}

\author{
Mark D. Mitchell
}

The hand coring program was carried out at Larson Village between June 25 and July 6, 2008. Project participants included SHSND staff members Amy Bleier, Paul Picha, Tim Reed, and Fern Swenson and PCRG staff member Mark Mitchell, who directed the work. A total of approximately 29 person-days was devoted to the effort. The investigation focused on two parts of the site. On the northern periphery, coring transects were used to investigate a linear magnetic anomaly recorded in 2006 as well as a low ridge or linear mound first observed in 2007. Several large, well-defined anomalies located outside Ditch 4 also were investigated. In the center of the village, coring was used to obtain data on prominent magnetic anomalies located inside visible topographic depressions. Two short transects also were placed across the projected track of Ditch 2 . Altogether, data were collected from a total of 129 probe holes. This chapter describes the methods used and discusses and interprets the results obtained.

\section{Methods}

In the Heart region, soil coring has become a routine technique for rapidly sampling geophysical anomalies and for investigating the depth and content of natural and cultural deposits and features (e.g. Ahler and Swenson 2003:36). In most cases, an Oakfield soil probe has been used to extract a column or plug of sediment 1-inch in diameter. Depending on soil moisture and on the frequency and size of obstructions, cores up to $250 \mathrm{~cm}$ long can be obtained. Each segment of the extracted core is approximately $20 \mathrm{~cm}$ long. Data on the strata observed and the artifacts encountered in the core are recorded on field forms designed for the purpose. The depths of strata and artifacts are measured from the modern surface using a metal tape measure, typically by determining the overall depth of the core hole, then subtracting the distance from the end of the coring tool to the stratigraphic contact or object of interest. Under some conditions, the coring tool can compress the sampled sediments and so depth measurements should be considered approximate. Typically, hand coring is carried out by teams of two people, with one person using the coring tool and measuring depths and the other taking notes.

Two methods have been used to select locations for coring. To sample discrete magnetic anomalies, which commonly represent the locations of hearths or debris-filled storage pits, coordinates are estimated from field maps displaying preliminary magnetic data. These positions are then staked out using tapes or a total station. Linear anomalies, or various kinds of surface features, generally are investigated by sampling at regular intervals along a transect. When possible, such transects are placed on major site grid lines.

At Larson, both linear and point sampling methods were used. Two short probe transects were used to investigate a linear anomaly just outside Ditch 4. Another was placed across a low, linear surface feature on the northern edge of the settlement. Transects also were used to confirm the track of Ditch 2 at two locations near the village core. Single probes or, in some cases, several 
closely spaced probes were used to investigate selected discrete anomalies in the village core and on the periphery of the site. Altogether, data were collected from a total of 129 probes. Table 3.1 summarizes these data, which are organized by the geophysical block in which the probe was located, by a consecutive anomaly number if applicable, and by the probe coordinates. The observed depth of cultural deposits and the maximum depth of the probe are given, along with a brief interpretation or explanation. Additional data from selected probes are discussed in the following sections. A map showing the locations of numbered geophysical blocks can be found in Kvamme (2008).

Table 3.1. Coring data, 2007 PCRG field investigations at Larson Village.

\begin{tabular}{|c|c|c|c|c|c|c|c|}
\hline $\begin{array}{l}\text { Probe } \\
\text { No. }\end{array}$ & $\begin{array}{c}\text { Block } \\
\text { No. }\end{array}$ & $\begin{array}{c}\text { Anomaly } \\
\text { No. }\end{array}$ & Northing & Easting & $\begin{array}{c}\text { Depth of } \\
\text { Cultural } \\
\text { Deposits } \\
(\mathrm{cm})\end{array}$ & $\begin{array}{l}\text { Max. } \\
\text { Probe } \\
\text { Depth } \\
(\mathrm{cm}) \\
\end{array}$ & Interpretation/Comment \\
\hline 1 & 8 & 1 & 545 & 500 & 73 & 132 & Upper soil truncated (?) \\
\hline 2 & 8 & 1 & 546 & 500 & 79 & 140 & Upper soil truncated (?) \\
\hline 3 & 8 & 1 & 547 & 500 & 95 & 135 & Upper soil truncated (?) \\
\hline 4 & 8 & 1 & 548 & 500 & 75 & 141 & Upper soil truncated (?) \\
\hline 5 & 8 & 1 & 549 & 500 & 57 & 139 & Two soils intact \\
\hline 6 & 8 & 1 & 550 & 500 & 55 & 130 & Two soils intact \\
\hline 7 & 8 & 1 & 551 & 500 & 67 & 131 & Upper soil truncated (?) \\
\hline 8 & 8 & 1 & 552 & 500 & 57 & 135 & Two soils intact \\
\hline 9 & 8 & 1 & 553 & 500 & 51 & 130 & Two soils intact \\
\hline 10 & 8 & 1 & 554 & 500 & 53 & 135 & Two soils intact \\
\hline 11 & 8 & 1 & 547.5 & 500 & 70 & 131 & Feature? \\
\hline 12 & 8 & 1 & 546.5 & 500 & 70 & 140 & Upper soil truncated (?) \\
\hline 13 & 8 & 1 & 548.5 & 500 & 55 & 136 & Munsell column; 2 soils intact \\
\hline 14 & 5 & 1 & 560 & 480.5 & 60 & 120 & Two intact soils \\
\hline 15 & 5 & 1 & 560 & 482 & 55 & 130 & Two soils intact \\
\hline 16 & 5 & 1 & 560 & 483 & 64 & 136 & Upper soil truncated (?) \\
\hline 17 & 5 & 1 & 560 & 484 & 53 & 131 & Two soils intact \\
\hline 18 & 5 & 1 & 560 & 485 & 64 & 124 & Upper soil truncated (?) \\
\hline 19 & 5 & 1 & 560 & 486 & 107 & 130 & Pit \\
\hline 20 & 5 & 1 & 560 & 486.5 & 93 & 127 & Pit \\
\hline 21 & 4 & 1 & 574 & 474 & 120 & 167 & Pit \\
\hline 22 & 4 & 1 & 575 & 474 & 104 & 127 & Pit \\
\hline 23 & 4 & 1 & 573.5 & 474 & 134 & 175 & Pit \\
\hline 24 & 4 & 2 & 572 & 470 & 118 & 160 & Ditch 4 edge \\
\hline 25 & 4 & 3 & 566 & 476 & 112 & 170 & Pit \\
\hline 26 & 2 & 1 & 593.5 & 458.5 & 56 & 175 & Two soils intact; badger backdirt \\
\hline 27 & 2 & 1 & 593.5 & 459.5 & 65 & 175 & Two soils intact; badger backdirt \\
\hline 28 & 2 & 1 & 593.5 & 459 & 63 & 175 & Two soils intact; badger backdirt \\
\hline 29 & 1 & 1 & 612 & 456 & 52 & 175 & Two soils intact; badger backdirt \\
\hline 30 & 1 & 1 & 612 & 457 & 43 & 175 & Two soils intact; badger backdirt \\
\hline 31 & 105 & & 612 & 484 & 91 & 175 & Mottled deposits below plowzone \\
\hline 32 & 105 & & 610 & 484 & 120 & 175 & Mottled deposits below plowzone \\
\hline 33 & 104 & & 620 & 476 & $62(?)$ & 175 & Upper soil may be disturbed \\
\hline 34 & 104 & & 620 & 477 & $68(?)$ & 175 & Upper soil may be disturbed \\
\hline 35 & 104 & & 620 & 478 & 121 & 175 & Mottled deposits below plowzone \\
\hline 36 & 104 & & 620 & 479 & 113 & 175 & Mottled deposits below plowzone \\
\hline 37 & 105 & & 620 & 480.5 & 113 & 170 & Mottled deposits below plowzone \\
\hline 38 & 105 & & 620 & 482 & 113 & 152 & Mottled deposits below plowzone \\
\hline
\end{tabular}


Table 3.1. Coring data, 2007 PCRG field investigations at Larson Village, continued.

\begin{tabular}{|c|c|c|c|c|c|c|c|}
\hline $\begin{array}{l}\text { Probe } \\
\text { No. }\end{array}$ & $\begin{array}{c}\text { Block } \\
\text { No. }\end{array}$ & $\begin{array}{c}\text { Anomaly } \\
\text { No. }\end{array}$ & Northing & Easting & $\begin{array}{l}\text { Depth of } \\
\text { Cultural } \\
\text { Deposits }\end{array}$ & $\begin{array}{l}\text { Max. } \\
\text { Probe } \\
\text { Depth }\end{array}$ & Interpretation/Comment \\
\hline 39 & 105 & & 620 & 484 & 116 & 166 & Mottled deposits below plowzone \\
\hline 40 & 105 & & 620 & 499 & 56 & 173 & Two soils intact \\
\hline 41 & 105 & & 620 & 495 & 59 & 168 & Two soils intact \\
\hline 42 & 105 & & 620 & 492 & 89 & 168 & Mottled deposits below plowzone \\
\hline 43 & 105 & & 620 & 490 & 90 & 171 & Mottled deposits below plowzone \\
\hline 44 & 105 & & 620 & 488 & 112 & 128 & Mottled deposits below plowzone \\
\hline 45 & 4 & 4 & 572.5 & 476.4 & 117 & 130 & Pit \\
\hline 46 & 12 & 1 & 523 & 511 & 111 & 126 & Edge of ditch or cultural deposit \\
\hline 47 & 12 & & 523 & 514 & 74 & 89 & Two soils intact \\
\hline 48 & 21 & 1 & 488.6 & 522.1 & 41 & 105 & Two soils intact (?) \\
\hline 49 & 21 & 1 & 488.3 & 522 & 92 & 95 & Pit \\
\hline 50 & 147 & 1 & 374 & 379.5 & 139 & 151 & Pit \\
\hline 51 & 161 & 1 & 316.5 & 384.5 & 171 & 171 & Hearth with underlying pit \\
\hline 52 & 161 & 3 & 317.5 & 390 & 170 & 179 & Pit \\
\hline 100 & 143 & 1 & 371 & 372 & $>51$ & 51 & Hearth (no data on underlying sed.) \\
\hline 101 & 143 & 2 & 379 & 373 & 42 & 90 & Cultural deposit \\
\hline 102 & 143 & 2 & 380 & 373 & 111 & 122 & Pit \\
\hline 103 & 143 & 3 & 361.5 & 377.5 & 168 & 180 & Pit \\
\hline 104 & 137 & 1 & 395 & 375 & 124 & 148 & Pit \\
\hline 105 & 138 & 1 & 395 & 395 & 90 & 145 & Weak anomaly; cultural deposit; no feature \\
\hline 106 & 138 & & 395 & 393.5 & 112 & 140 & No anomaly; pit beneath surface depression \\
\hline 107 & 138 & 2 & 381.5 & 399.5 & 170 & 198 & Pit \\
\hline 108 & 139 & 1 & 396.5 & 418 & 61 & 142 & Hearth \\
\hline 109 & 136 & 1 & 406 & 437.5 & $>80$ & 80 & Hearth (no data on underlying sed.) \\
\hline 110 & 136 & 2 & 418 & 432 & 87 & 121 & Hearth \\
\hline 111 & 135 & 1 & 419 & 418 & 142 & 150 & Pit \\
\hline 112 & 135 & 2 & 417.5 & 412.5 & 67 & 118 & Cultural deposit; no feature identified \\
\hline 113 & 135 & 2 & 417.5 & 411.5 & 134 & 142 & Pit \\
\hline 114 & 134 & 1 & 418 & 389 & 91 & 147 & Pit \\
\hline 115 & 137 & 2 & 383 & 376 & 85 & 132 & Anomaly present; no feature identified \\
\hline 116 & 133 & 1 & 407.5 & 375 & 75 & 144 & No anomaly present; no feature identified \\
\hline 117 & 134 & 2 & 412.5 & 389.5 & 148 & 172 & Pit \\
\hline 118 & 138 & 3 & 388.5 & 395.5 & 111 & 144 & Pit \\
\hline 119 & 138 & 4 & 381 & 397 & $>203$ & 203 & Pit \\
\hline 120 & 142 & 1 & 392.5 & 468.5 & 68 & 93 & Weak anomaly; no feature identified \\
\hline 121 & 38 & 1 & 408 & 462 & 152 & 158 & Pit \\
\hline 122 & 38 & 2 & 405 & 460 & 108 & 144 & Pit \\
\hline 123 & 38 & 3 & 403 & 463 & 101 & 126 & Cultural deposit; no feature identified \\
\hline 124 & 38 & 3 & 403 & 462.5 & 80 & 118 & Cultural deposit; no feature identified \\
\hline 125 & 38 & 4 & 415 & 476 & 53 & 96 & Dipole (?); no feature identified \\
\hline 126 & 38 & 5 & 418 & 476 & 126 & 135 & Small anomaly; pit \\
\hline 127 & 37 & 1 & 420 & 457.5 & 185 & 190 & Pit \\
\hline 128 & 34 & 1 & 423.5 & 485 & 102 & 122 & Pit \\
\hline 129 & 34 & 2 & 424.5 & 486 & 113 & 126 & Pit \\
\hline 130 & 29 & & 440 & 485 & 139 & 149 & Ditch 2 \\
\hline 131 & 29 & & 440 & 488 & 101 & 109 & Ditch 2 \\
\hline 132 & 29 & & 440 & 482 & 90 & 112 & Ditch 2 \\
\hline 133 & 131 & 1 & 426 & 404.5 & 65 & 125 & Hearth \\
\hline
\end{tabular}


Table 3.1. Coring data, 2007 PCRG field investigations at Larson Village, concluded.

\begin{tabular}{|c|c|c|c|c|c|c|c|}
\hline $\begin{array}{l}\text { Probe } \\
\text { No. }\end{array}$ & $\begin{array}{c}\text { Block } \\
\text { No. }\end{array}$ & $\begin{array}{c}\text { Anomaly } \\
\text { No. }\end{array}$ & Northing & Easting & $\begin{array}{l}\text { Depth of } \\
\text { Cultural } \\
\text { Deposits }\end{array}$ & $\begin{array}{l}\text { Max. } \\
\text { Probe } \\
\text { Depth }\end{array}$ & Interpretation/Comment \\
\hline 134 & 22 & 1 & 476.5 & 450 & 162 & 180 & Pit \\
\hline 135 & 22 & 2 & 479 & 447.5 & 155 & 175 & Pit \\
\hline 136 & 124 & 1 & 470 & 388 & 52 & 165 & Anomaly present; no feature identified \\
\hline 137 & 118 & & 499.5 & 416.2 & 134 & 178 & Pit \\
\hline 138 & 161 & 2 & 316 & 387 & 205 & 205 & Pit \\
\hline 201 & 150 & 1 & 357.5 & 368 & 40 & 210 & Anomaly present; no feature identified \\
\hline 202 & 150 & 1 & 357 & 368 & 68 & 210 & Anomaly present; no feature identified \\
\hline 203 & 150 & 2 & 357 & 365 & 90 & 230 & Anomaly present; no feature identified \\
\hline 204 & 151 & 1 & 355.5 & 392.5 & 210 & 210 & Pit \\
\hline 205 & 151 & 2 & 356 & 393.5 & 85 & 173 & Pit \\
\hline 206 & 151 & & 356 & 395.5 & 126 & 170 & No anomaly; pit or cultural deposit \\
\hline 207 & 151 & & 356 & 396.5 & 53 & 150 & Weak anomaly; no feature identified \\
\hline 208 & 151 & & 355.7 & 397.5 & 125 & 175 & Weak anomaly; pit or cultural deposit \\
\hline 209 & 151 & & 355.6 & 398.5 & 107 & 130 & No anomaly; pit or cultural deposit \\
\hline 210 & 151 & & 356 & 399.5 & 205 & 235 & No anomaly; pit \\
\hline 211 & 145 & 1 & 362 & 412.5 & 114 & 175 & Pit or cultural deposit \\
\hline 212 & 145 & 2 & 362 & 413.5 & 96 & 135 & Pit or cultural deposit \\
\hline 213 & 146 & 1 & 365 & 432.5 & $>65$ & 65 & Hearth with underlying pit \\
\hline 214 & 146 & 1 & 365 & 432.5 & 140 & 140 & Hearth with underlying pit \\
\hline 215 & 146 & 1 & 366 & 433.7 & 133 & 192 & Pit \\
\hline 216 & 146 & 2 & 374 & 426.5 & $>172$ & 172 & Pit \\
\hline 217 & 146 & 3 & 373 & 427 & 115 & 157 & Pit \\
\hline 218 & 140 & 1 & 384 & 434 & $>45$ & 45 & Hearth with underlying pit \\
\hline 219 & 140 & 1 & 384.2 & 434 & 163 & 198 & Hearth with underlying pit \\
\hline 220 & 140 & 2 & 386.5 & 431 & 147 & 155 & Pit \\
\hline 221 & 148 & 1 & 373 & 464.5 & $>54$ & 54 & Weak anomaly; pit or cultural deposit \\
\hline 222 & 148 & 1 & 373 & 464.4 & 115 & 145 & Weak anomaly; pit or cultural deposit \\
\hline 223 & 148 & 2 & 370.5 & 464.5 & 121 & 145 & Weak anomaly; pit or cultural deposit \\
\hline 224 & 149 & & 380 & 490 & 102 & 110 & Cultural deposit \\
\hline 225 & 149 & & 380 & 486 & 137 & 162 & Cultural deposit \\
\hline 226 & 149 & & 380 & 487 & $>73$ & 73 & Cultural deposit \\
\hline 227 & 149 & & 380 & 486.9 & 104 & 120 & Cultural deposit \\
\hline 228 & 149 & & 380 & 485 & $>60$ & 60 & Cultural deposit \\
\hline 229 & 149 & & 380 & 484.9 & $>65$ & 65 & Cultural deposit \\
\hline 230 & 149 & & 379.5 & 485 & 127 & 144 & Cultural deposit \\
\hline 231 & 149 & & 380 & 488 & 97 & 126 & Cultural deposit \\
\hline 232 & 149 & & 380 & 493 & 87 & 110 & Cultural deposit \\
\hline 233 & 149 & & 380 & 496 & 80 & 90 & Cultural deposit \\
\hline 234 & 28 & 2 & 460 & 465.5 & 185 & 195 & Pit or cultural deposit \\
\hline 235 & 28 & 1 & 448.5 & 471 & 76 & 105 & Weak anomaly; no feature identified \\
\hline 236 & 128 & 1 & 453 & 405.5 & $>61$ & 61 & Pit \\
\hline 237 & 128 & 1 & 453 & 405.7 & 126 & 160 & Pit \\
\hline 238 & 125 & 1 & 466 & 407 & 190 & 190 & Pit \\
\hline
\end{tabular}

Horizontal control for the coring program was provided by a metric grid system. Figure 3.1 illustrates the major features of the site along with the site grid and the locations of three permanent datums. Each datum consists of a 3/8-inch steel reinforcing bar set flush with the ground surface. 


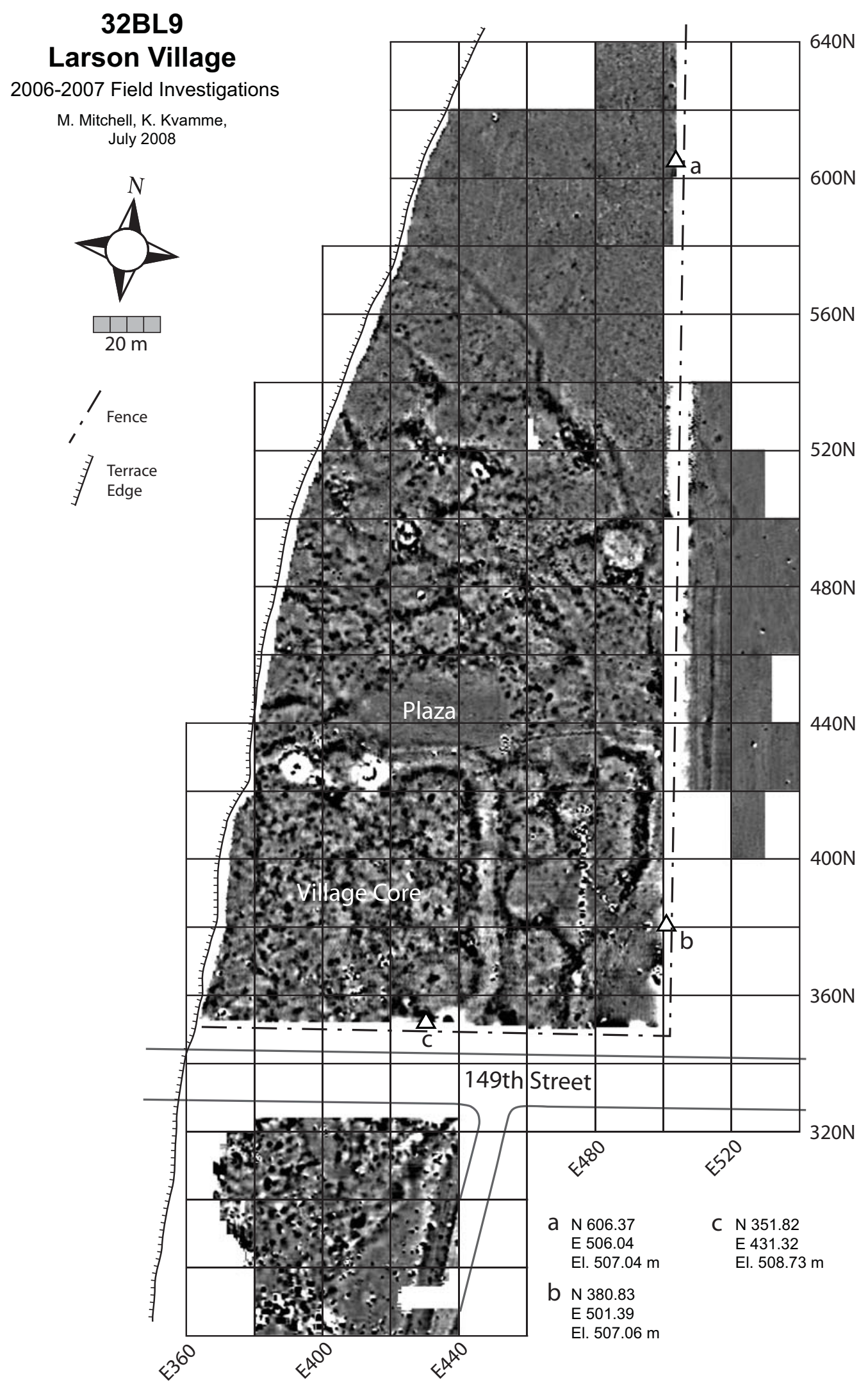

Figure 3.1. Map of Larson Village showing the site grid, datum locations, and geophysical survey area. 
One is located in the village core, approximately $1.3 \mathrm{~m}$ north of the east-west right-of-way fence near the highest part of the site (351.82NE431.32, $508.73 \mathrm{~m}$ ). Two others are located on the eastern edge of the village, approximately $1.3 \mathrm{~m}$ west of the north-south pasture fence (606.37NE506.04, $507.04 \mathrm{~m}$ and 380.83NE501.39, 507.06). All three datums were set at the conclusion of the 2006 field investigations and were relocated for the 2007 work. The 2007 grid coincides quite closely with the original grid (Figure 3.2). The relative positions of the three permanent datums, as well as of a wooden hub used as a temporary total station position, varied between the two grids by 3 to 5

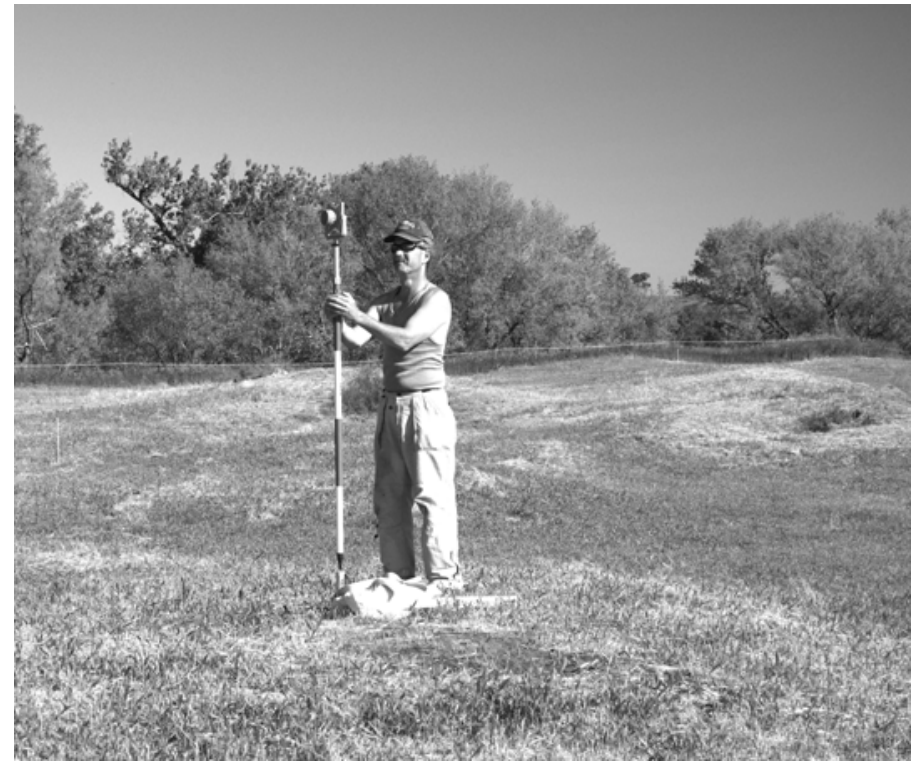

Figure 3.2. Paul Picha setting out the site grid. $\mathrm{cm}$. The 2007 grid covered the entire site west of the north-south pasture fence, including about eight full blocks and six partial blocks south of $149^{\text {th }}$ Street. Probe locations were staked out from the $20-\mathrm{m}$ grid corners using flexible tapes.

Prior to the start of fieldwork, SHSND staff made arrangements with the landowner and leaseholder for access to the site. Permission to access the portion of the site south of $149^{\text {th }}$ Street was obtained by PCRG. To improve surface visibility and to facilitate the geophysical and topographic surveys, the area north of $149^{\text {th }}$ Street was mowed by SHSND personnel. The area south of $149^{\text {th }}$ Street was mowed by Paul Andahl.

\section{Results}

The results obtained from the coring program are discussed in the following two sections. The first presents data from the northern and southern edges of the settlement, while the second presents data from the village core.

\section{Village Periphery Studies}

Three types of features were investigated on the northern periphery of the site. First, two short probe transects were placed across a faint linear magnetic anomaly identified as a possible fortification ditch during the analysis of data collected in 2006. This feature, informally dubbed "Ditch 5," is visible in Geophysical Block 8, where it appears to parallel Ditch 4. One transect was placed along the E500 grid line while the second was placed along the $560 \mathrm{~N}$ grid line. Probe spacing varied between $50 \mathrm{~cm}$ and $1 \mathrm{~m}$.

A comparatively uniform stratigraphic sequence was observed in these cores. The upper sediment package varies from about 42 to $67 \mathrm{~cm}$ in thickness and consists of homogeneous brown silt containing a little charcoal but few artifacts. Below this is a zone of mottled, compact silt. This 
unit also varies in thickness. In some places is rests directly on a weakly-developed soil lying 55 to $60 \mathrm{~cm}$ below the surface, but in other places the soil's A horizon appears to have been stripped away and the mottled layer extends well into the B horizon at a depth of 70 to $90 \mathrm{~cm}$. In every probe hole a sharp contact was observed at a depth of 95 to $105 \mathrm{~cm}$ between the B horizon of the upper soil and the top of a deeper, better-developed soil. The lower soil formed in fine-grained deposits and contains abundant carbonate stringers and blebs. This same soil was exposed in two of the 2006 test excavation units (Ditch 4 and Block G). Thus, the depth of cultural deposits observed in the two 2007 probe transects varied from less than $50 \mathrm{~cm}$ to about $90 \mathrm{~cm}$. By contrast, data obtained in 2006 demonstrated that the floor of Ditch 4 currently is about $1.5 \mathrm{~m}$ below the modern ground surface, while the floor of Ditch 3 is over $2 \mathrm{~m}$ down. The probe results indicate that the "Ditch 5" anomaly could represent a fortuitous alignment of small pit features or a shallow basin or trough, but that it does not appear to represent a fifth fortification ditch. A pit feature was identified at 560NE486, lending some support to this interpretation.

The second type of feature investigated on the northern periphery was a low ridge or linear mound about $20 \mathrm{~cm}$ high, 12 to $15 \mathrm{~m}$ wide, and at least $50 \mathrm{~m}$ long extending northward from the northern edge of the village. In the Knife River region, similar linear mounds have been observed at both Lower Hidatsa and Big Hidatsa villages (Ahler and Weston 1981; Ahler and Swenson 1985). For instance, at Big Hidatsa, five linear mounds radiate to the west and north from the village core; another crescent-shaped mound also has been documented. These vary in length from 80 to $230 \mathrm{~m}$ and are 10 to $15 \mathrm{~m}$ wide. They also vary in prominence, from just a few $\mathrm{cm}$ to as much as $50 \mathrm{~cm}$ high. In the Heart region, only one linear feature resembling the mounds at Big Hidatsa has been documented. At Double Ditch Village a northwest-trending ridge has been documented north of one of the northern-most major midden mound (Geib 2004:71). This feature is also attested in the magnetic data as a positive linear anomaly. It has been interpreted as the remnant edge of a broad, shallow borrow basin covering much of the northern periphery of the site.

To investigate the linear mound at Larson, a coring transect consisting of 12 probe holes was placed long the 620N grid line, from E476 to E499 (Figure 3.3). Cores on the eastern and western ends of this transect produced results similar to those obtained in the "Ditch 5" transects. On either side of the mound the upper homogeneous silt unit varies in thickness from 56 to $68 \mathrm{~cm}$ and below that the natural terrace sediments remain undisturbed. However, under the mound, mottled, disturbed sediment extends to a depth of $121 \mathrm{~cm}$, indicating that the upper soil and a significant portion of the lower soil have been stripped away. Few artifacts were encountered, but the strongly mottled character of the sediment suggests that the mound is a constructed feature. At Big Hidatsa, auger testing and hand excavation in fact demonstrated that the linear mounds are artificial embankments, but they appear not to have been built over an earlier borrow feature (Ahler and Swenson 1985:39). The functions of these features are not known, but they may be connected in some way to trails that also radiate from the village. At Larson, additional investigation, perhaps including hand excavation, would be needed to delineate the feature and track its history.

On the northern edge of the settlement the field investigation also focused on several large, discrete magnetic anomalies. These areas of higher magnetism could represent debris-filled storage pits or hearths, but, they might also represent areas of extensive animal disturbance or other natural processes. Six of the most prominent anomalies on the northern and eastern edges of the settlement, outside the Ditch 4 perimeter, were sampled. Four of these turned out to represent pits, while two were determined to be spoil piles created by badgers. All of the pits were located quite close to Ditch 4. However, several moderately-sized anomalies located farther north, along the axis of the 


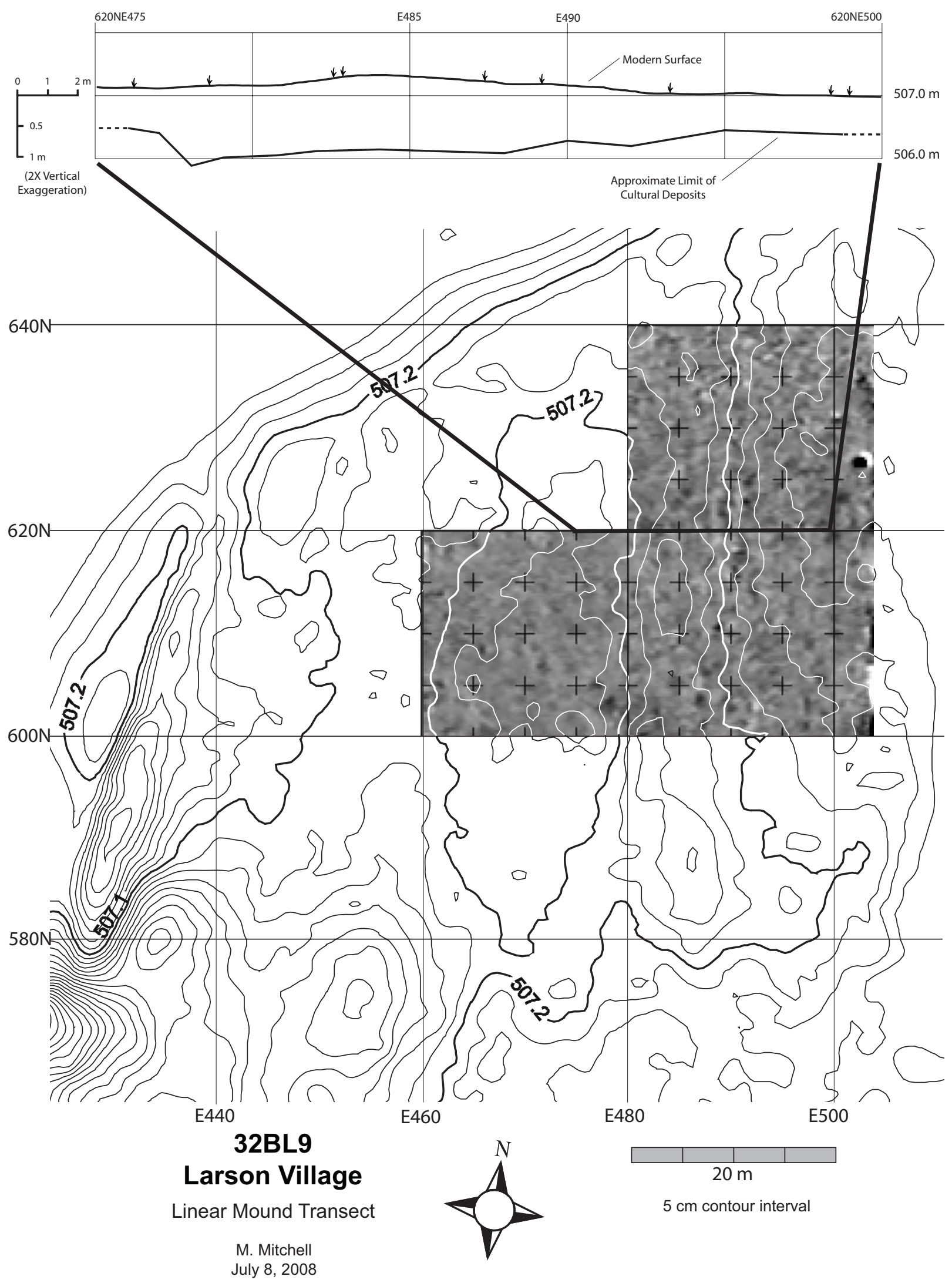

Figure 3.3. Plan and cross-section of the linear mound. 
linear mound, were not investigated; at Big Hidatsa, excavation revealed the presence of a bellshaped pit near the crest of Mound C (Ahler and Swenson 1985:37). These results indicate that at least a few pit features are present outside Ditch 4.

On the southern periphery of the village, unsystematic coring was used to bracket the maximum spatial extent of cultural deposits. (Data on these probes are not included in Table 3.1). At the beginning of the 2007 field work, a large cut was observed in the edge of the terrace about 15 m south of the modern residence on the southern end of the site. Initially, the research team suspected that this cut might represent the location of one of the outer fortification ditches. However, coring along the centerline of the cut demonstrated that no cultural deposits are present. Closer inspection of sediment apparently pushed out of the cut onto the floodplain below confirmed its relatively recent origin. The road built in the late 1930s from the terrace down to the floodplain is located immediately north of house. Thad Hecker's excavations there demonstrated that the site originally extended at least that far south (Swenson 2007). Thus, the southern boundary of the site must lie near or under the house. Unsystematic coring on both sides of the driveway running along the east side of the house produced sporadic evidence of cultural deposits.

\section{Summary}

Coring on the northern and southern margins of the site helped define the maximum extent of cultural deposits. Although a fifth fortification ditch was not identified, coring did demonstrate that the low ridge on the northern edge of the site is in fact an artificial embankment and additionally that several large pit features are present outside the Ditch 4 perimeter. On the south side of the site coring confirmed the presence of cultural deposits adjacent to, but not far south of, the modern residence. Thus, the site currently covers about 5.1 ha (12.7 ac), although an unknown fraction of the original site area has been lost to bank erosion.

Coring on the northern periphery of the site also provided additional data on the thickness of cultural deposits there and on the natural strata making up the terrace. The northern periphery is mantled by a relatively thick deposit of homogeneous brown silt containing relatively few artifacts. The formation history of this deposit is not known, but it clearly has been modified to some extent by plowing. In many places this unit rests on an intact soil, the upper surface of which lies at and elevation of about 506.45 to 506.50. The relationship between this soil and those exposed in the 2006 test units inside Ditch 3 is not entirely clear. Stratigraphic data from Block A, Block F, and especially Block D indicate that the village originally was built on a weakly developed soil at about 506.90 (Mitchell 2007:Figure 4.20). In each of these test units, a thin, intermittent layer of light brown to olive loess overlies this soil, representing fill generated by the construction of cache pits and other features. The seeming absence of this soil north of Ditch 3 may indicate that it was stripped away by widespread, but shallow sediment borrowing. However, other data suggest that the soil at 506.50 may have been contemporaneous with the soil at 506.90. The lower soil formed in finer-grained sediments that may have accumulated in a shallow basin. This interpretation is suggested by the presence of an even more deeply buried soil that formed in clay which rests on top of laterally extensive loess deposits. This soil is distinctive for its very fine texture and for its abundant carbonate inclusions. Both coring and excavation data indicate that it is confined to the eastern third of the site; the soil at 506.50 appears to have a similar distribution. 


\section{Village Core Studies}

Two types of features were investigated in the village core. Most of the coring effort was directed toward a search for large hearth features. The presence of a central hearth can be taken as confirmation that the depression in which it is located represents the former location of an earthlodge. These data were used mainly in the interpretation of surface features, which is described in Chapter 4. Methods for differentiating the magnetic signature of a large hearth from that of a pit or other type of feature are discussed in Chapter 2. Table 3.2 presents summary data on the eight identified central hearths.

Table 3.2. Coring data on eight hearth features identified during the 2007 PCRG field investigations at Larson Village.

\begin{tabular}{|c|c|c|c|c|c|c|c|}
\hline $\begin{array}{l}\text { Probe } \\
\text { No. }\end{array}$ & $\begin{array}{c}\text { Block } \\
\text { No. }\end{array}$ & $\begin{array}{c}\text { Anomaly } \\
\text { No. }\end{array}$ & Northing & Easting & $\begin{array}{l}\text { Depth of } \\
\text { Cultural } \\
\text { Deposits }\end{array}$ & $\begin{array}{c}\text { Max Probe } \\
\text { Depth }\end{array}$ & Interpretation/Comment \\
\hline \multicolumn{8}{|c|}{ Hearths Built on Sterile Sediment $(n=3)$} \\
\hline 108 & 139 & 1 & 396.5 & 418 & 61 & 142 & Hearth \\
\hline 110 & 136 & 2 & 418 & 432 & 87 & 121 & Hearth \\
\hline 133 & 131 & 1 & 426 & 404.5 & 65 & 125 & Hearth \\
\hline \multicolumn{8}{|c|}{ Hearths Built on Unknown Deposits $(n=2)$} \\
\hline 100 & 143 & 1 & 371 & 372 & $>51$ & 51 & Hearth (no data on underlying sed.) \\
\hline 109 & 136 & 1 & 406 & 437.5 & $>80$ & 80 & Hearth (no data on underlying sed.) \\
\hline \multicolumn{8}{|c|}{ Hearths Built on Pre-existing Cultural Deposits ( $n=3$ ) } \\
\hline 51 & 161 & 1 & 316.5 & 384.5 & 171 & 171 & Hearth with underlying pit \\
\hline 213 & 146 & 1 & 365 & 432.5 & $>65$ & 65 & Hearth with underlying pit \\
\hline 214 & 146 & 1 & 365 & 432.5 & 140 & 140 & Hearth with underlying pit \\
\hline 218 & 140 & 1 & 384 & 434 & $>45$ & 45 & Hearth with underlying pit \\
\hline 219 & 140 & 1 & 384.2 & 434 & 163 & 198 & Hearth with underlying pit \\
\hline
\end{tabular}

In addition to these hearths, coring in the center of the village also documented a variety of large pit features, ranging in depth from about $90 \mathrm{~cm}$ to more than $2 \mathrm{~m}$. Artifact densities varied significantly among the identified pits. In some cases, the probe may have intersected several superimposed features. A number of probes revealed the presence of charred roof fall, indicating that at least some of the most recently occupied structures burned. Coring also demonstrated that the bastion-like bend in Ditch 1 on the north side of the village core in fact surrounds a pre-existing earthlodge. Similar bends in Ditch 1 at Double Ditch may also have been necessitated by the presence of earthlodges or mounds when the ditch was built.

A hearth was identified on the south side of the $149^{\text {th }}$ Street, indicating that parts of at least one earthlodge are preserved there. The distribution of magnetic anomalies near this hearth suggests that several lodges may be present. However, informal coring suggests that cultural deposits south of the $260 \mathrm{~N}$ grid line have been severely impacted by modern construction. In particular, a triangular portion of the site west of the gravel driveway appears to have been bladed, perhaps to obtain construction fill. Modern ferrous debris is widely scattered across this part of the site.

Surprisingly, several probes encountered undisturbed terrace sediments at a depth of just 50 or $60 \mathrm{~cm}$. Assuming that the pre-village surface was level, this result suggests that during the period of occupation the accumulation of cultural debris in the village core was approximately balanced by the removal of such sediment. For the most part, significant debris deposits were not allowed to accumulate, but at the same time sterile sediment was not stripped away as was the case at Double 
Ditch. The net result was a modest accumulation of debris across much of the site surface. Figure 3.4 illustrates the portion of the modern surface lying below the projected pre-village surface. Significant sediment borrowing took place in the central plaza and a second large basin just east of Ditch 1. However, stratigraphic data obtained in 2006 indicates that borrowing, followed by deposition of culturally modified sediment, took place elsewhere in the village.

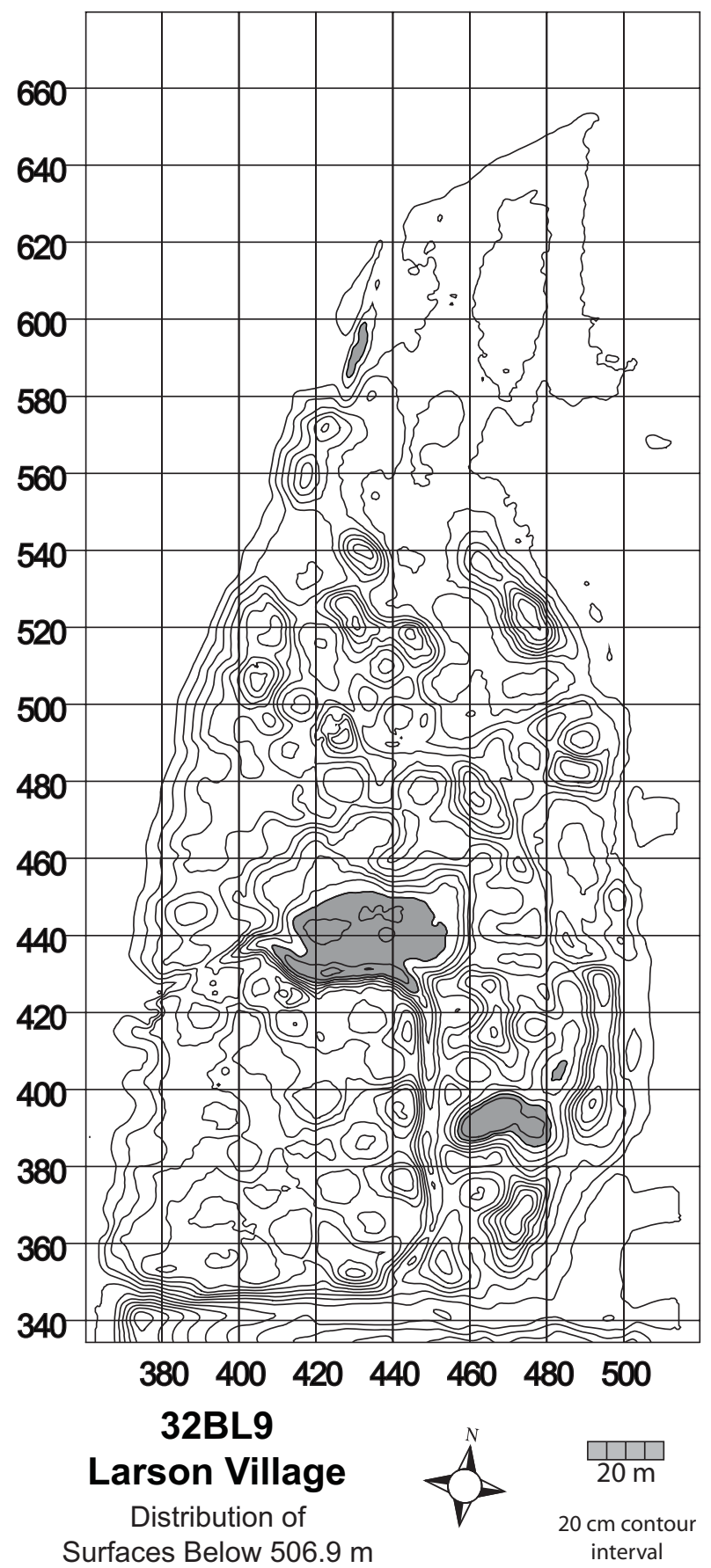

Figure 3.4. Map showing deep borrow basins at Larson Village. Shaded areas lie below $506.9 \mathrm{~m}$.
Coring also was used to better define the position of Ditch 2 on the eastern edge of the site. Two short coring transects were placed across the projected track of the ditch in two locations. Probe spacing varied from 1 to $3 \mathrm{~m}$. Three probes across the ditch on the $440 \mathrm{~N}$ grid line corroborated previously collected magnetic and topographic data indicating its presence. At that point the ditch is at least $139 \mathrm{~cm}$ deep. However, ten probes across the projected track of the ditch on the $380 \mathrm{~N}$ grid line failed to locate it. The depth of cultural deposits in this part of the site is fairly uniform, ranging from $80 \mathrm{~cm}$ to $127 \mathrm{~cm}$. Slightly thicker deposits on the west end of the transect reflect the proximity of the large, linear mound marking the eastern perimeter of the village.

\section{Summary}

Coring in the center of the village confirmed the presence of at least 11 substantially intact earthlodges, including at least one south of $149^{\text {th }}$ Street. Ten more probable structures were also identified. Several of the lodges appear to have been burned. In contrast to the situation at Double Ditch Village, cultural debris accumulated in the center of the village at Larson, but that accumulation was relatively modest, ranging from $50 \mathrm{~cm}$ to as much as $1.5 \mathrm{~m}$ in a few places. The track of Ditch 2 through the center of the village is complex and not well documented. Coring confirmed its location on the north side of the easternmost perimeter mound, but on the south side of the mound it could not be located. Originally, it may have swung to the east, into what is now a cultivated field, and crossed $149^{\text {th }}$ Street well east of the access gate to the site. 


\section{References Cited}

Ahler, Stanley A., and Anthony A. Swenson

1985 Test Excavations at Big Hidatsa Village (32ME12), Knife River Indian Villages National

Historic Site. Contribution No. 218. Department of Anthropology, University of North

Dakota, Grand Forks. Submitted to the USDI National Park Service, Midwest

Archaeological Center, Lincoln, Nebraska.

Ahler, Stanley A., and Fern E. Swenson

2003 Investigations During 2001. In Archaeological Investigations During 2001 and 2002 at

Double Ditch State Historic Site, North Dakota, edited by Stanley A. Ahler, pp. 35-52.

Research Contribution No. 56. PaleoCultural Research Group, Flagstaff, Arizona. Submitted to the State Historical Society of North Dakota, Bismarck.

Ahler, Stanley A., and Timothy Weston

1981 Test Excavations at Lower Hidatsa Village (32ME10), Knife River Indian Villages National Historic Site. Department of Anthropology and Archeology, University of North Dakota, Grand Forks. Submitted to the USDI National Park Service, Midwest Archaeological Center, Lincoln, Nebraska.

Geib, Phil R.

2004 Ditch Investigations. In Archaeological Investigations During 2003 at Double Ditch State Historic Site, North Dakota, edited by Stanley A. Ahler, pp. 97-104. Research Contribution No. 60. PaleoCultural Research Group, Flagstaff, Arizona. Submitted to the State Historical Society of North Dakota, Bismarck.

Kvamme, Kenneth L.

2008 Final Larson Site (32BL9) Geophysical Data Archive. Archeo-Imaging Lab, Department of Anthropology, University of Arkansas, Fayetteville. Submitted to the State Historical Society of North Dakota, Bismarck.

Mitchell, Mark D.

2007 Excavation Results. In Geophysical Survey and Test Excavation During 2006 at Larson Village, Burleigh County, North Dakota, edited by Mark D. Mitchell, pp. 57-85. Research Contribution No. 80. PaleoCultural Research Group, Flagstaff, Arizona. Submitted to the State Historical Society of North Dakota, Bismarck.

Swenson, Fern E.

2007 Previous Investigations at Larson Village. In Geophysical Survey and Test Excavation During 2006 at Larson Village, Burleigh County, North Dakota, edited by Mark D. Mitchell, pp. 11-25. Research Contribution No. 80. PaleoCultural Research Group, Flagstaff, Arizona. Submitted to the State Historical Society of North Dakota, Bismarck. 


\title{
4. SURFACE FEATURE INTERPRETATION
}

\author{
Mark D. Mitchell, Fern E. Swenson, and Paul R. Picha
}

\section{Introduction}

Archaeologists working in the northern Middle Missouri commonly have used the number of shallow, roughly circular depressions as a proxy for the number of houses built at a site and, indirectly, community population. For instance, Alfred W. Bowers (1948:161), counted 504 depressions at five sites, including Double Ditch, Slant, Boley, Motsiff, and Larson villages, from which he estimated a population of about 6,000. However, recent investigations in the Heart region have exposed two fundamental flaws in this approach. First, it is now clear that the occupational histories of these sites were very dynamic. At Double Ditch Village, several lines of evidence document the progressive contraction of the settlement over time, from a maximum in the early 1500s of 162 houses to a minimum of fewer than 40 when it was abandoned some 300 years later. A similar pattern is evident at Larson. However, at a larger scale the picture is more complex. Boley Village, located on the west bank of the Missouri a few km south of Larson and Double Ditch, may have increased in size over the same period; in any case, it seems to have been rebuilt with a new orientation sometime during the late 1600s or early 1700s. Thus, the size of each settlement varied over time and, at the same time, no single model of demographic change can be applied to all sites in the region.

Second, work at Double Ditch has shown that many of the depressions thought to represent the former locations of earthlodges in fact represent borrow basins or other features. Excavation carried out in 2003 designed to explore a depression thought to mark the location of a longrectangular lodge ultimately revealed a complex sequence of construction, borrowing, and infilling (Geib 2004). On the surface, the depression seemed to conform rather closely in size and shape to the distinctive depressions marking the known locations of long-rectangular lodges, such as those preserved at Huff Village (Wood 1967:Map 15). However, the field investigation clearly demonstrated that the features encountered were merely the remnants of debris-filled storage pits, the tops of which had been stripped away. Some time later, the entire basin was refilled with homogeneous silt bearing comparatively few artifacts. Even if a long-rectangular house had stood on this spot at one time, there is no meaningful relationship between that structure and the current surface feature.

For these reasons, it is clear that a simple count of visible depressions is not an effective proxy for momentary population. In some cases, this method will produce an estimate that is too large, but in others the estimate will be too small. To increase their accuracy and resolution, demographic reconstructions require not only a site-specific model of occupational history but also house density estimates derived from detailed interpretations of visible surface features. This chapter discusses the methods used to classify surface features at Larson and presents the results of a detailed study of such features located inside Ditch 2. 


\section{Field Methods and Data Analysis}

The method used to interpret surface features at Larson was adapted from an approach developed by Stan Ahler for similar work at Double Ditch Village (Ahler et al. 2005). Ahler’s technique involved three steps. First, a sketch map was made of the village core and the mapped topographic features were assigned to one of nine functional categories, including "mound," "pothole," "basin," "house," and so forth. The crucial aspect of this first step was the classification of features using a model of idealized functional attributes (discussed in greater detail in the next section), rather than simply their size or location. Next, those interpretations were refined in the lab by comparing the sketch maps with a high-resolution topographic map of the site. Topographic data were used mainly to adjust the shapes and positions of features documented on the sketch map. Finally, geophysical data were superimposed on the adjusted topographic maps and the functional interpretations further refined.

At Larson, the initial annotated sketch map of the village core and surrounding area used to classify depressions was created using a Trimble GeoExplorer 3 handheld GPS receiver. Points were collected on the 20-m grid corners set out for the geophysical and topographic surveys and on readily identifiable surface features such as the centerline of Ditch 1 and the pasture fences surrounding the site. Points were then recorded on the rim of each visible depression. The position of the rim was determined subjectively. These data were then differentially corrected and the resulting shapefile was printed, along with the 20 -m site grid, on 36-inch plotter paper. Using this map, each feature was assigned to one of the nine previously established categories. At the same time, adjustments were made to the shapes and positions of the features recorded by the GPS unit. This map was limited to the portion of the site south and west of Ditch 2 and north of $149^{\text {th }}$ Street.

In a departure from the methods used at Double Ditch, the functional interpretations made during the field assessment at Larson were based to a significant degree on subsurface coring data. This was possible because preliminary magnetic maps of the village core were available nearly in real-time, while fieldwork was still underway. Coordinates selected for coring were chosen by correlating the mapped locations of discrete magnetic anomalies with the boundaries of visible depressions. Anomalies nearest to the center of each depression were selected, on the assumption that, in addition to the criteria discussed in the next section, central hearths might be preserved in the depressions marking house locations. Maps showing magnetic anomalies along with the site grid system were printed at roughly 1:200 scale, or two 20-m grids per page. The coordinates of selected anomalies were estimated from the printed map, which displayed tick marks at 5-m intervals, and then staked out using tape measures anchored to the site grid corners.

In the lab, topographic maps of the site were created using XYZ-data collected by the Trimble 5600 robotic total station. Spacing between the data points averaged about $1 \mathrm{~m}$. The horizontal spatial resolution of the resulting maps is about $50 \mathrm{~cm}$ and the vertical accuracy is about $1 \mathrm{~cm}$. The mapping program Surfer (v.6.0) was used to manipulate the coordinate dataset and generate contour maps at various scales. The feature interpretations made in the field were then fitted to these maps. In a few cases, minor modifications were made to the size, shape, or position of particular features. Finally, magnetic data from the site were examined to determine if additional adjustments were needed and again several minor changes were made. During this process, a few features were re-classified. Inside Ditch 1, one depression was changed from a possible basin to a definite basin. Two other depressions outside Ditch 1 also were changed from possible to definite 
basins. The most notable change involved the large, slightly oblong depression immediately north of the plaza. Bowers (1940) believed that this was the location of the Okipa lodge in view of its size and position. In the field this feature initially was classified as a possible house. However, no evidence for a floor or central hearth was observed and its depth and irregular outline in the magnetic data suggests that it more likely is a basin.

Coring data were collected by Amy Bleier, Paul Picha, Tim Reed, and Fern Swenson. Details on coring methods and a description of the results are given in Chapter 3. Initial feature interpretations were made by Swenson, Picha, and Mark Mitchell. The contour map was created by Mitchell, using three-dimensional coordinate data collected and processed by Ken Kvamme; methods for manipulating these data are presented in Chapter 2. The final feature classification was performed by Mitchell.

\section{Topographic Feature Classes}

The classes described here largely replicate those used by Ahler and others (2005) for their study of Double Ditch Village. Topographic features are divided into two classes: elevated areas and depressions. Elevated areas with relief greater than about $1 \mathrm{~m}$ are classified as mounds, while lower areas are classified as humps or isolated elevated areas. At Double Ditch, Will and Spinden (1906) assigned letter designations to the most conspicuous mounds, as well as to some lower, less prominent elevated areas. Similar designations have not been applied to mounds at Larson. A few deep depressions at Larson are classified as potholes, where they clearly are a result of unprofessional digging. Several of these are encircled by backdirt piles. A few shallow depressions are classified as Alfred Bowers's excavation locations. Unlike George Will and Herbert Spinden at Double Ditch, Bowers appears to have backfilled his excavation units, and as a result their locations are now not well expressed on the surface.

The remaining depressions have been assigned to one of four categories: houses, possible houses, basins, and possible basins. The definitions of these groups are polythetic, in that specific features usually meet most but not all of the criteria for group membership. Functionally, houses represent the former locations of earth-covered, timber-frame structures similar to those constructed in the nineteenth and twentieth centuries by Mandans, Hidatsas, and Arikaras. Basins are depressed areas created by sediment borrowing, likely in conjunction with the construction of nearby earthlodges.

House depressions nearly always are circular in form. The few that are not range from slightly elongated to subrectangular. Most are 10 to $12 \mathrm{~m}$ in diameter; at Double Ditch, the minimum size was $8 \mathrm{~m}$, while the maximum was $15 \mathrm{~m}$. Most are relatively shallow and have level floors. At Double Ditch, the height of the terrain surrounding most lodge depressions was uniform, mainly because accumulated sediment in the village core had been stripped away before the last round of lodge construction took place. By contrast, basins typically are irregular in form; many are elongated or curving. The height of the terrain surrounding them can vary and may include several distinct mounds or humps. Basins often seem to intersect one another. In such cases, the floors of the conjoined basins generally differ in elevation or may be sloping or undulating. Many basins are deeper than nearby depressions interpreted at houses. Finally, basins generally are larger than houses. Despite the seeming specificity of these criteria it was sometimes difficult to make 
definitive group assignments. In such cases, features were assigned to the provisional house or basin groups based on a preponderance of evidence.

\section{Feature Classification and Discussion}

Figure 4.1 illustrates the central portion of the site north of $149^{\text {th }}$ Street and depicts the areas covered by the two smaller-scale maps that show the sizes and positions of various features (Figures 4.2 and 4.3). Seven feature types are illustrated on the detailed maps; for clarity, minor elevated areas and looter's backdirt piles are omitted. This section describes and discusses the major feature classes identified in this part of the site.

\section{Fortification Ditches}

Ditch 1 is well expressed along nearly its entire length north of $149^{\text {th }}$ Street. It consistently measures between 5 and $7 \mathrm{~m}$ in width, but varies somewhat in depth. On the northwest, near its intersection with the cutbank, it has been filled completely. Given the proximity of several large potholes, this may have taken place recently. On the east side of the village core, Ditch 1 has been partly filled with sediment from several large midden mounds. Coring at 430NE440, adjacent to the plaza, demonstrated that it was once well more than $2 \mathrm{~m}$ deep. The distinctive "negative” magnetic signature of Ditch 1 is discussed at some length in Chapter 2. Because it has been only partly filled, the ditch appears on the magnetic map as a narrow band of comparatively low magnetism. Clearly, Ditch 1 is the most recent of the site's fortification systems, given its clear definition and the fact that it appears to have been cut through several pre-existing mounds. It also bends sharply around House 6 on the north side of the village core, indicating that a structure was present in this location when the ditch was built.

By contrast, Ditch 2 is only intermittently expressed. It is most evident immediately north of the large, linear mound on the eastern rim of the settlement, where it can be traced for a distance of 80 or $90 \mathrm{~m}$. To the northwest, a second, shorter segment of the ditch is faintly visible. It does not appear to be expressed on the surface south of the $410 \mathrm{~N}$ grid line. In a few places a low berm is apparent on the inside of the ditch. Where it can be measured it appears to be somewhat wider than Ditch 1, but this may be due simply to erosion. Coring data from the centerline of the ditch at 440NE485 indicate that it once was at least $1.8 \mathrm{~m}$ deep. Magnetically, Ditch 2 is somewhat similar to Ditch 1, although the band of negative magnetism is less pronounced.

\section{Basins}

Most of the large basins or possible basins are located outside Ditch 1 . The largest of these, the plaza, is ringed by a group of smaller basins that, based on coring data, appear to have been excavated into cultural deposits. Another large basin is located just outside Ditch 1 to the east. Surface features classified at basins share a number of topographic and magnetic features. Most are elliptical or irregular in plan and are comparatively deep, with unevenly sloping sides. A few exhibiting more circular plans are classified as possible basins. Most of the depressions classified as basins are much larger than those classified as houses but several are smaller. Two particularly 


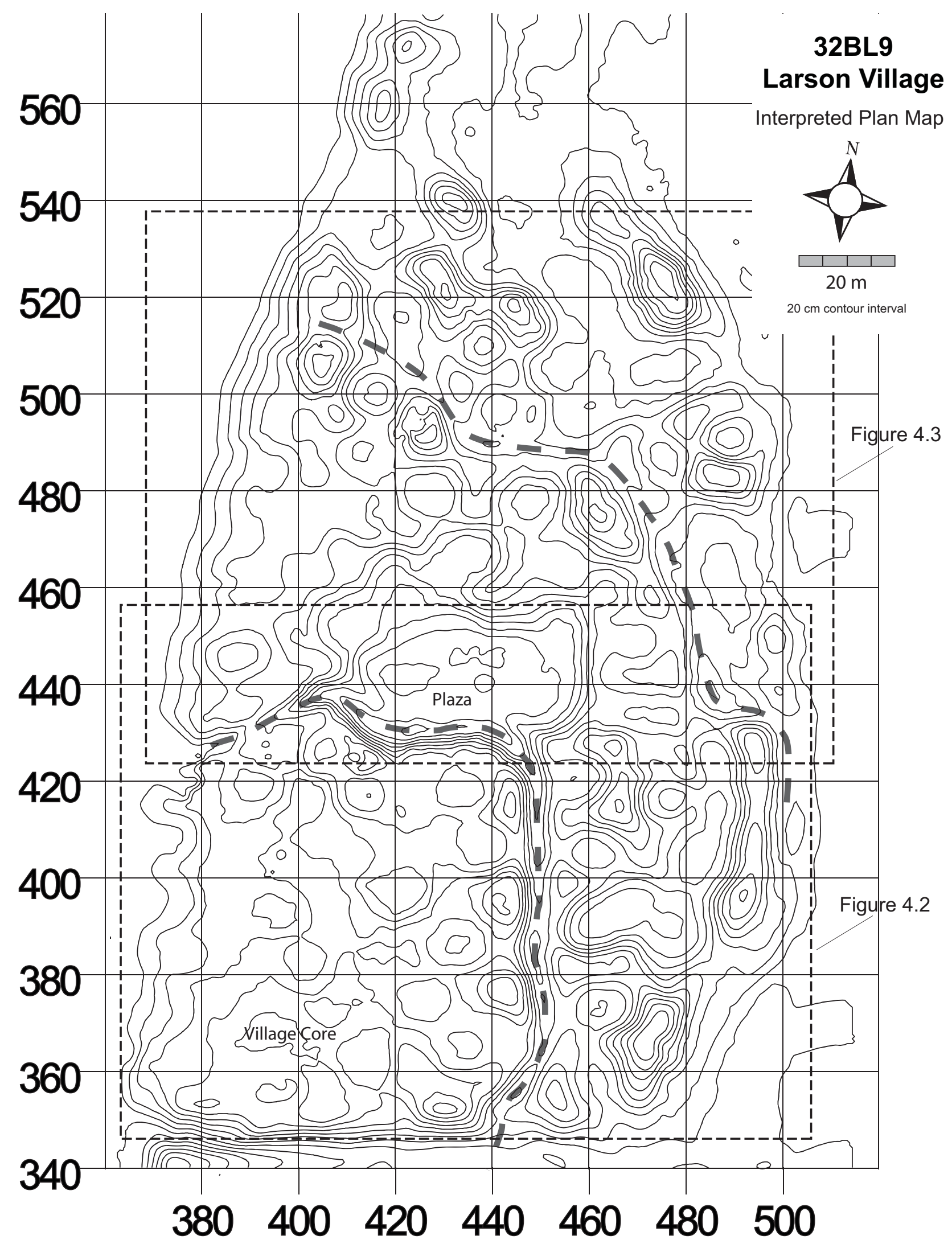

Figure 4.1. Topographic map showing the central portion of Larson Village. The areas covered by Figures 4.2 and 4.3 are indicated by dashed lines. 


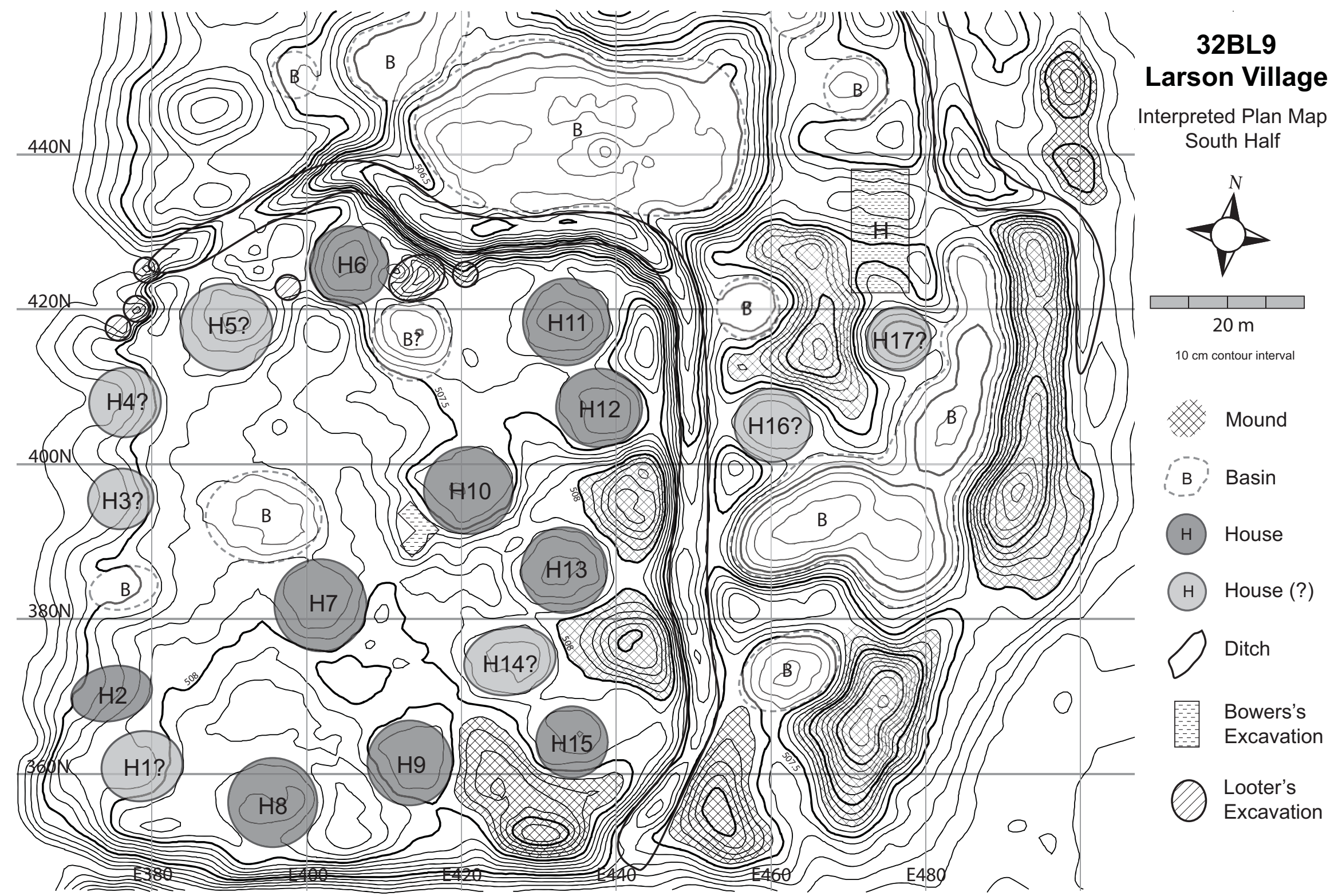

Figure 4.2. The south half of the interpreted plan map for Larson Village, overlaid onto a 10-cm interval contour map. 


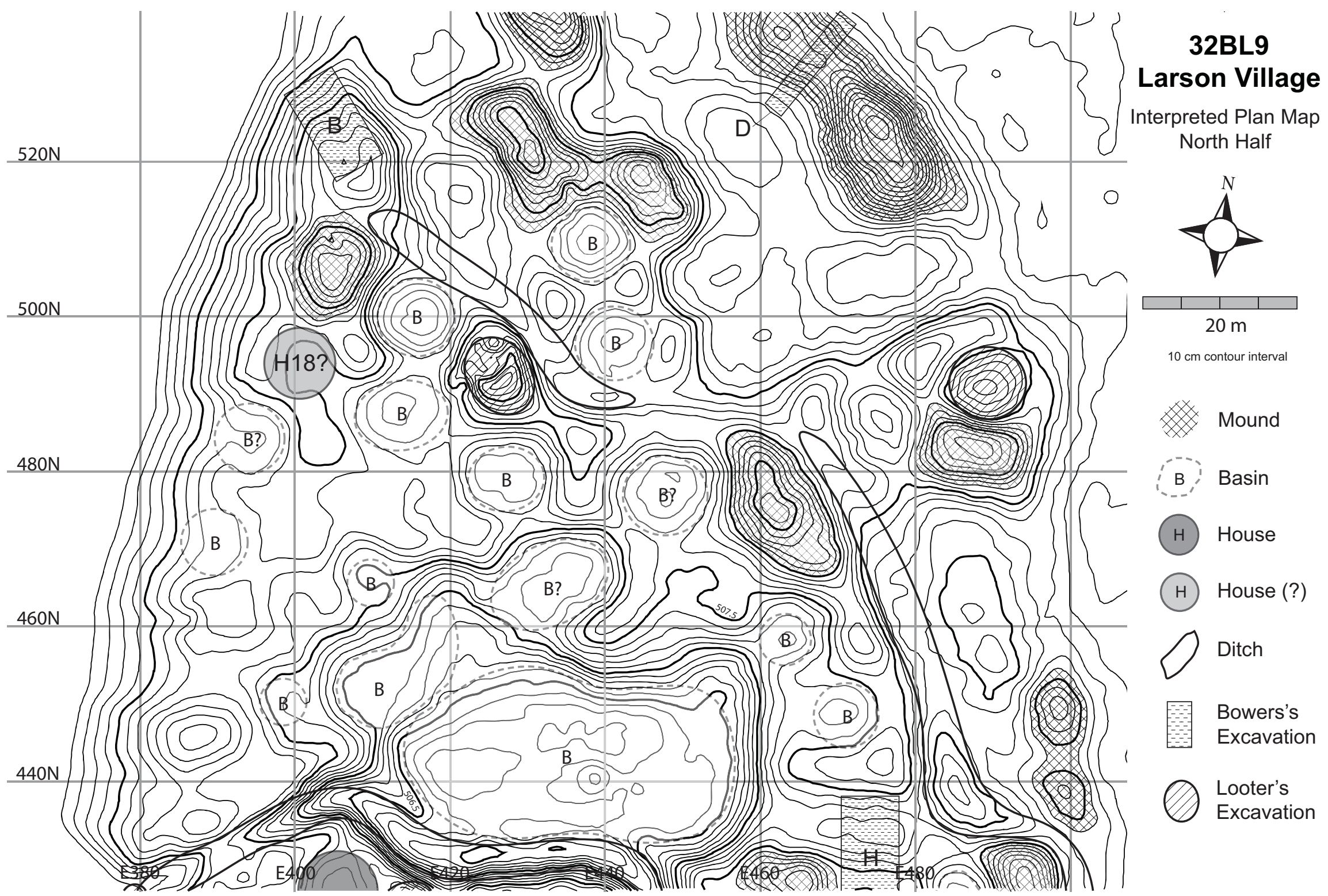

Figure 4.3. North half of the interpreted plan map for Larson Village, overlaid onto a 10-cm contour interval map. 
small basins are located west of the plaza. The plaza is unique among features designated as basins in that it contains a circular elevated area or hump, which Bowers (1940) identifies at the location of the Arc of the First Man. The magnetic map also indicates that the plaza is entirely devoid of features, which seem to be present in all of the smaller basins. Three basins or possible basins were identified in the village core. The largest of these appears to mark an open area inside Ditch 1 . The possible basin southeast of House 6 may represent a looted house, given its depth.

\section{Historic Excavations and Potholes}

Four of Alfred Bowers's excavation units are plotted on the interpreted maps. The locations of Work B and Work D only are approximate and are based mainly on his map (see Figure 1.5) and written description (Bowers 1940). Magnetic data bearing on their locations are somewhat equivocal (see Figure 2.20). The location of Work $\mathrm{H}$ is more secure. Bowers's map puts Work $\mathrm{H}$ due east of the bend in Ditch 1, between two large mounds. The magnetic data for this area (Block 33) show a rectangular area of lower magnetism that may mark the southern end of the excavation unit (Swenson 2007:Figure 2.8). Bowers did not give a letter designation to the small L-shaped unit he opened up in the village core and its position relative to other features of the site has not been clear. However, it is clearly indicated in the magnetic and topographic data for Block 139. (Bowers's fifth excavation unit, which he called Work A, was located south of $149^{\text {th }}$ Street).

Eight potholes are plotted on the interpreted maps. Most of these are located in the northwestern corner of the village core. Looters also may have substantially altered two other nearby depressions, one classified as a possible house and one classified as a possible basin. A twotrack road runs from this part of the site east toward the pasture fence and the access gate to the site. All of the features identified as potholes are deep and steep-sided, and are located adjacent to spoil piles. One pothole, located just inside Ditch 2 may be as much as $1.5 \mathrm{~m}$ deep. Another, located outside Ditch 2 close to the eastern edge of the site, was identified mainly based on magnetic data. An enigmatic, ring-shaped anomaly roughly $8 \mathrm{~m}$ in diameter at the bottom of this depression may represent the location of an earthlodge, but the depression itself fails to meet any of the previously discussed criteria for an earthlodge depression. Most of these potholes appear to have been excavated some time ago; however, one pit dug into the fill of Ditch 1 where it intersects the cutbank may be more recent.

\section{Houses}

Eighteen depressions are classified as houses or possible houses (Table 4.1). A combination of topographic, magnetic, and coring data was used to make these assignments. Seven of the 11 definite house depressions contain central hearths. Four others were identified by the presence of an apparent floor, by their size and shape, or by the frequency and distribution of magnetic anomalies inside them. With the exception of House 2, all of the definite houses have flat floors that lie 20 to $30 \mathrm{~cm}$ below the surrounding terrain. In several cases, the surrounding surface is considerably higher on one side of the house. The floors seem to occur at somewhat different elevations. For example, the floor of House 11 is about $20 \mathrm{~cm}$ below the floor of House 12, and houses on the south side of the village core are higher than those on the north. In plan, most houses are markedly circular. The smallest is $8 \mathrm{~m}$ in diameter, while the largest is $15 \mathrm{~m}$. However, most are $12 \mathrm{~m}$. 
Table 4.1. Data on houses and possible houses, 2007 PCRG field investigations at Larson Village.

\begin{tabular}{|c|c|c|c|c|}
\hline House & Dia. (m) & Hearth? & Magnetic Pattern & Comment \\
\hline H1? & 10 & No & Few features inside; pits outside on NE & Some evidence for burned roof fall \\
\hline $\mathrm{H} 2$ & $8 \times 11$ & Yes & Several features inside; few outside & $\begin{array}{l}\text { Some evidence for burning; depression } \\
\text { is elliptical; partially eroded }\end{array}$ \\
\hline H3? & 8 & No & One large feature inside; few outside & Probably a basin; partially eroded \\
\hline H4? & 10 & No & No features inside; pits outside on E & Partially eroded \\
\hline H5 & 12 & No & Several large features inside; pits outside & Likely looted \\
\hline H6 & 10 & Yes & $\begin{array}{l}\text { Clear central hearth, few other features } \\
\text { inside; pits outside }\end{array}$ & Well expressed house \\
\hline H7 & 15 & No & Several large features inside; pits outside & Large depression \\
\hline H8 & 13 & No & Several large features inside; pits outside & $\begin{array}{l}\text { Some evidence for intact floor; large } \\
\text { depression }\end{array}$ \\
\hline H9 & 12 & No & Several large features inside; pits outside & $\begin{array}{l}\text { Edge of house not well defined; dipoles } \\
\text { obscure pattern }\end{array}$ \\
\hline $\mathrm{H} 10$ & 12 & Yes & Few large features inside; pits outside & $\begin{array}{l}\text { Edge of house not well defined on W; } \\
\text { hearth not prominent }\end{array}$ \\
\hline H11 & 12 & Yes & $\begin{array}{l}\text { Several large features inside; small pits } \\
\text { outside }\end{array}$ & Very prominent hearth; lodge burned \\
\hline H12 & 12 & Yes & Several large features inside; pits outside & $\begin{array}{l}\text { Prominent hearth, slightly off-center; } \\
\text { lodge burned }\end{array}$ \\
\hline H13 & 12 & Yes & Several large features inside; pits outside & Prominent hearth slightly off-center \\
\hline H14? & $10 \times 13$ & No & Few features inside & $\begin{array}{l}\text { Edge of house not well defined; } \\
\text { possibly a basin }\end{array}$ \\
\hline H15 & $10 ?$ & Yes & One large feature inside; pits outside & $\begin{array}{l}\text { Superimposed hearth and pit; mag. data } \\
\text { indicates lodge is } 12 \mathrm{~m} \text { in dia. }\end{array}$ \\
\hline H16? & 11 & No & $\begin{array}{l}\text { Several large features inside; thick cultural } \\
\text { deposits outside }\end{array}$ & $\begin{array}{l}\text { Circular depression, but surrounded by } \\
\text { mounds and basins }\end{array}$ \\
\hline H17? & 10 & No & $\begin{array}{l}\text { Several large features inside; thick cultural } \\
\text { deposits outside }\end{array}$ & $\begin{array}{l}\text { Circular depression; but surrounded by } \\
\text { mounds and basins }\end{array}$ \\
\hline H18? & 10 & No & $\begin{array}{l}\text { Few features inside; thick cultural deposits } \\
\text { outside }\end{array}$ & Circular depression \\
\hline
\end{tabular}

Depressions classified as houses exhibit a distinctive magnetic signature. Each house is marked by a zone of comparatively low magnetism, punctuated by one or more discrete positive anomalies. By contrast, the house floor is surrounded by numerous discrete anomalies as well as, in some cases, an amorphous zone of higher magnetism that may represent a complex series of superimposed features or perhaps sheet midden deposits. In most cases the boundary of the floor is sharply defined. Coring demonstrated that the interior anomalies represent both hearths and debrisfilled storage pits. Interestingly, several hearths appear to be off-center relative to the magnetically defined limits of the house floor.

Three of the depressions in the village core that are classified as possible houses intersect the cutbank. If its central hearth had not been preserved, House 2 also likely would have been classified as a possible house. However, its apparent elliptical form and sloping floor almost certainly were caused by erosion. The House 5 depression is comparatively deep, and may have been enlarged by looters. Only three possible houses are located outside Ditch 1. All of these are circular, but are somewhat smaller than definite houses. None of them contain central hearths. The small number of possible house depressions located between Ditch 1 and Ditch 2, coupled with the large number of depressions classified as basins in that same area, suggests that the Ditch 1 community existed for a lengthy period. 


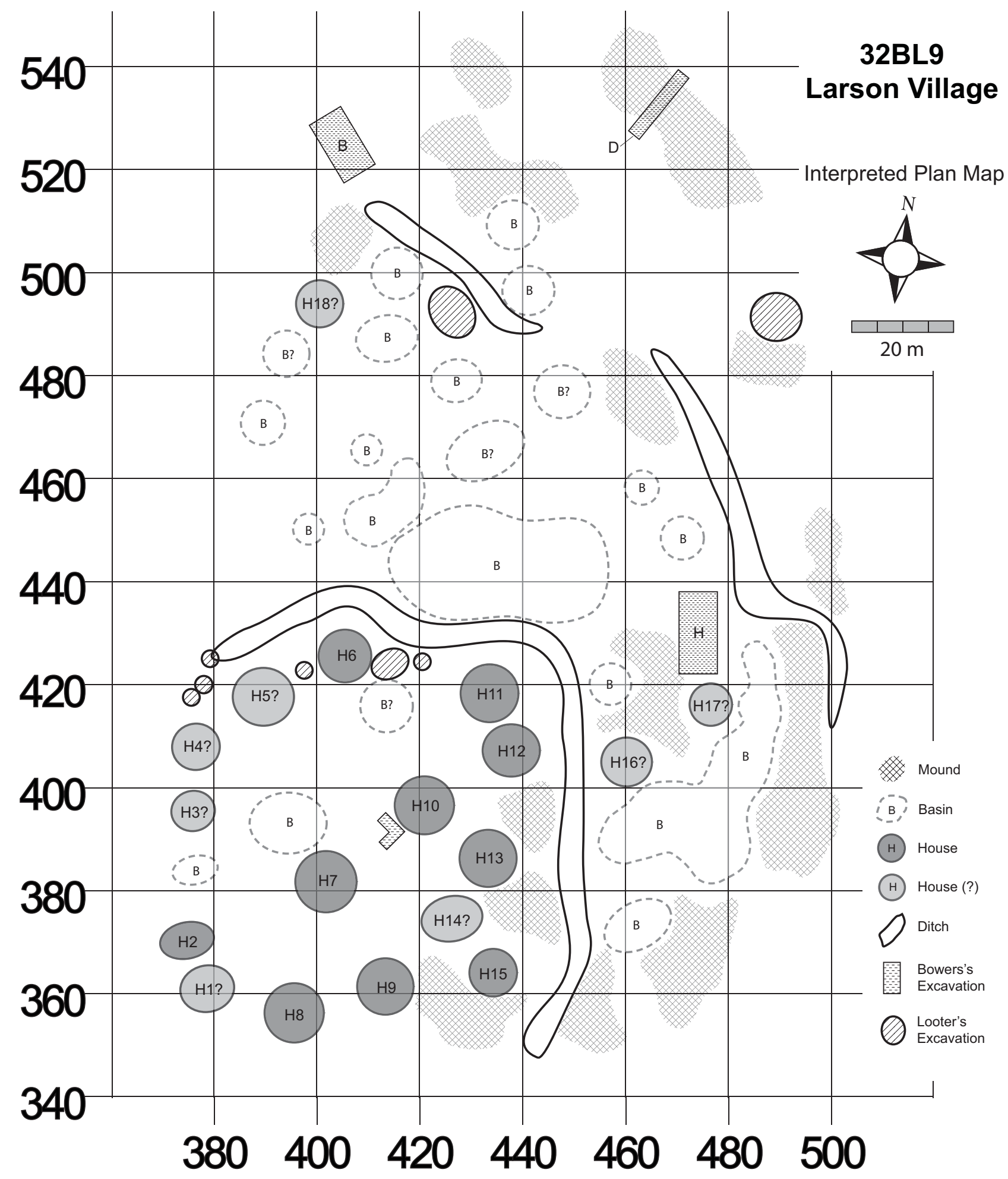

Figure 4.4. Composite interpreted plan map, Larson Village.

The area inside Ditch 1, north of $149^{\text {th }}$ Street, is about 0.6 ha (1.5 ac). Assuming that all 15 houses or possible houses identified in this area were occupied simultaneously, the density would have been about 25 houses/ha (10 houses/ac). At Double Ditch, 33 likely or possible houses are distributed over an area of 1.67 ha (4.1 ac) inside Ditch 1, or about 20 houses/ha (8 houses/ac). 
Other calculated values range from 21 houses/ha (8.5 houses/ac) at the fifteenth-century Huff Village (32MO11) to 23 houses/ha (9.3 houses/ac) at Big Hidatsa Village (32ME12) in the Knife region. Assuming a mean value of 22.5 houses/ha, the founding community at Larson would have included at least 115 lodges, enough to house roughly 1,380 people. 


\section{References Cited}

Ahler, Stanley A., Fern E. Swenson, Eileen Ernenwein, and Christine Markussen

2005 Interpreted Mapping. In Archaeological Investigations during 2004 at Double Ditch State Historic Site, North Dakota, edited by Stanley A. Ahler, pp. 33-61. Research Contribution No. 65. PaleoCultural Research Group, Flagstaff, Arizona. Submitted to the State Historical Society of North Dakota, Bismarck.

Bowers, Alfred W.

1940 Missouri River Earthlodge Archaeology of North Dakota and South Dakota. Ms. on file at the Logan Museum of Anthropology, Beloit College, Beloit, Wisconsin.

1948 A History of the Mandan and Hidatsa. Ph.D. dissertation, Department of Anthropology, University of Chicago. University Microfilms International, Ann Arbor, Michigan.

Geib, Phil R.

2004 House Investigations. In Archaeological Investigations During 2003 at Double Ditch State Historic Site, North Dakota, edited by Stanley A. Ahler, pp. 105-121. Research

Contribution No. 60. PaleoCultural Research Group, Flagstaff, Arizona. Submitted to the State Historical Society of North Dakota, Bismarck.

Swenson, Fern E.

2007 Previous Investigations at Larson Village. In Geophysical Survey and Test Excavation During 2006 at Larson Village, Burleigh County, North Dakota, edited by Mark D. Mitchell, pp. 11-25. Research Contribution No. 80. PaleoCultural Research Group, Flagstaff, Arizona. Submitted to the State Historical Society of North Dakota, Bismarck. Will, George F., and Herbert J. Spinden

1906 The Mandans: A Study of Their Culture, Archaeology, and Language. Papers of the Peabody Museum of American Archaeology and Ethnology 3(4):81-219.

Wood, W. Raymond

1967 An Interpretation of Mandan Culture History. Smithsonian Institution, Bureau of American Ethnology Bulletin 198. River Basin Surveys Papers No. 39. U.S. Government Printing Office, Washington, D. C. 


\title{
5. INVENTORY AND ANALYSIS OF EXISTING COLLECTIONS
}

\author{
Mark D. Mitchell and Fern E. Swenson
}

\section{Introduction}

This chapter describes the pottery and stone and bone tools recovered by Alfred W. Bowers during his 1929 excavations at Larson Village. These objects currently are held by the Logan Museum of Anthropology at Beloit College, which sponsored Bowers's work at the site (Green et al. 2002). An inventory of artifacts from Larson held by the SHSND also is presented. These include specimens collected from the surface of the site at various times, as well as those excavated by Thad Hecker, probably in 1940, and by SHSND staff archaeologists in 1975. Finally, the results of two recent analyses of portions of the SHSND collections are briefly summarized. This presentation is meant to supplement the interpretations and conclusions derived from analyses of artifacts and other materials recovered during the 2006 testing program and to encourage further study of the collections curated by the SHSND and the Logan Museum.

The data presentation consists mainly of simple tabulations accompanied by brief descriptions. Pottery vessel rims and stone tools collected by Bowers were studied by Mitchell during a visit to the Logan Museum in June 2008. Most of the specimens in the SHSND collection have not been studied, but one small lot of rim sherds has been examined (Ahler 2001) and several classes of bone tools have been analyzed in detail (Griffitts 2006). Swenson compiled information on the SHSND collections. Mitchell compiled data on the Logan Museum collection and wrote the chapter.

\section{Logan Museum of Anthropology Collection}

The Logan Museum's collections include nearly 7,700 ethnographic objects and 69,000 archaeological specimens. About 20 percent of the archaeological collection-more than 13,000 objects - was obtained by Bowers during three field seasons in North Dakota and South Dakota from 1929 to 1931. Altogether, Bowers carried out field investigations at 39 village sites; the Larson Village assemblage includes approximately 1,814 specimens (Green et al. 2002). In 2006, the museum was awarded a \$355,000 grant from the National Endowment for the Humanities to upgrade their curation facilities. The goals of the NEH project are to improve access to the collections and to ensure their long-term preservation.

At Larson, Bowers opened up five excavation blocks (Bowers 1940; Swenson 2007; see also Chapter 4 of this report). Two of these, designated Work B and Work D, were located on the northern periphery of the settlement and were centered on large midden mounds. Work H was located closer to the core of the village and was placed over a lodge depression. Work A was located on the southwest edge of the site, where Ditch 1 intersects the cutbank, and was designed to expose several large cache pits outside lodges. The fifth block consisted of a small, L-shaped unit inside Ditch 1. Given what is now known about the occupational history of the village, it is likely 
that all of the contexts investigated by Bowers post-date those investigated in 2006. The mound exposed by Work D clearly formed after the pit features documented by the 2006 excavations were abandoned and filled. Ditch 4 also likely was filled by the time the Work D mound had formed. Work $\mathrm{H}$ and Work A, located closer to the center of the village, likely exposed even younger deposits, while the small L-shaped block in the village core likely produced the most recent.

Bowers says relatively little about his field methods in the draft manuscript describing his excavations at Larson and elsewhere. Although he measured the depths and described the contents of the layers he encountered, he used a trenching method in which excavation proceeded horizontally, rather than vertically, by advancing a face or headwall through the full thickness of the deposits. Most of his work focused on midden mounds and cache pits, rather than lodge floors. He drew profiles and plan maps of his excavation units, but with the single exception of a plan view of Work H (Swenson 2007:Figure 2.8) these appear now to have been lost. He did not use a screen to capture small items and rarely retained unmodified faunal remains, smaller body sherds, or flaking debris. The relative dearth of stone tools in the Logan Museum collection suggests that with a few exceptions he kept only patterned tools that were complete or nearly so. At several sites Bowers separated pottery sherds into upper and lower lots in each excavation unit. He also described aspects of the contents of each excavation unit in his narrative. However, he failed to write provenience or catalog information on the specimens he collected and any association between them and his original excavation units has since been lost. Existing catalog numbers were assigned in the late 1960s and early 1970s and group artifacts by material class and type. However, Bowers's own inventory of "complete" artifacts from the site generally agrees with the inventory of specimens held by the museum.

\section{Bone and Antler Tools}

Table 5.1 presents a breakdown of 414 bone tools collected by Bowers into 19 functional classes. Descriptions of these classes, along with a general discussion of the analytic methods commonly applied to bone tool collections from the Heart region, can be found in Ahler and Ryser (1997) and Ahler (2005). Data on the sample of 217 bone tools recovered in 2006 are presented in Falk (2007). Because only a handful of tools in the Logan Museum collection were examined closely, the classification presented in Table 5.1 is based largely on gross morphological characteristics, rather than on a combination of use wear, morphology, and manufacturing evidence as is usually the case. Formal analysis certainly would demonstrate that a wider range of functional classes is present.

The collection is dominated by patterned awls and pressure flakers. Awls occur in a wide variety of sizes and forms and mostly were made from the limb bones of small- and medium-sized mammals. By contrast, the items classified here as pressure flakers were made almost exclusively on split bison ribs and therefore are morphologically uniform. However, this apparent uniformity almost certainly conceals significant functional variability. Use wear studies indicate that, in addition to flinknapping, such split rib tools were used to process porcupine quills, bison hides, and a variety of other materials (Griffitts 2006:271).

The collection also includes 40 bison scapula hoes. Many of these were manufactured using

metal tools, although a few exhibit clear evidence of having been made with stone tools (Ahler and 
Table 5.1. Inventory of modified bone and antler artifacts from Larson Village held by the Logan Museum of Anthropology.

\begin{tabular}{|c|c|c|}
\hline Functional Class & $n$ & $\%$ \\
\hline \multicolumn{3}{|l|}{ Digging Tools } \\
\hline 10 cultivating tool & 40 & 9.7 \\
\hline \multicolumn{3}{|l|}{ Piercing Tools } \\
\hline 20 patterned awl/punch & 200 & 48.3 \\
\hline 45 expedient punch & 4 & 1.0 \\
\hline Subtotal & 204 & 49.3 \\
\hline \multicolumn{3}{|l|}{ Fishhooks } \\
\hline 30 fishhook & 3 & 0.7 \\
\hline \multicolumn{3}{|l|}{ Pressure Flakers } \\
\hline 22 patterned pressure flaker & 102 & 24.6 \\
\hline \multicolumn{3}{|l|}{ Other Patterned Tools } \\
\hline 17 squash knife & 29 & 7.0 \\
\hline 26 shaft straightener & 15 & 3.6 \\
\hline 40 antler scraper handle & 1 & 0.2 \\
\hline 54 unspecified rib tool & 4 & 1.0 \\
\hline 57 knife handle & 4 & 1.0 \\
\hline Subtotal & 53 & 12.8 \\
\hline \multicolumn{3}{|l|}{ Other Expedient Tools } \\
\hline 12 expedient cutting tool & 1 & 0.2 \\
\hline 58 unspecified antler tool & 2 & 0.5 \\
\hline 60 unspecified expedient tool & 1 & 0.2 \\
\hline Subtotal & 4 & 0.9 \\
\hline \multicolumn{3}{|l|}{ Non-Utilitarian } \\
\hline 3 tube & 1 & 0.2 \\
\hline 4 gaming piece & 1 & 0.2 \\
\hline 5 whistle & 3 & 0.7 \\
\hline 32 antler wrist guard & 1 & 0.2 \\
\hline 59 antler choker & 1 & 0.2 \\
\hline 62 bow-lance tip. & 1 & 0.2 \\
\hline Subtotal & 8 & 1.7 \\
\hline Total & 414 & 99.7 \\
\hline
\end{tabular}

Falk 2002:13.9-13.15). Most of the remaining bone tools consist of shaft wrenches made from bison ribs and squash knives made from bison scapulae. Four knife handles are present in the collection. One of these was made on a rib segment and retains a small fragment of its steel blade, which likely was 1 to $2 \mathrm{~mm}$ thick (Figure 5.1). A second handle, made on a long bone, also was originally fitted with a thick steel blade. The remaining two handles were fitted with thin steel blades no more than about $0.5 \mathrm{~mm}$ thick.

Minor components of the assemblage include three bird-bone whistles (two definite and one possible), three fishhooks, and three decorated split-rib tools. A new functional class (Class 62, ceremonial weapon tip) was created for a large arrowpoint-shaped object probably manufactured from a thick fragment of cortical bone (Figure 5.1). Similar artifacts made from flaked stone have been documented in several Heart region collections and are thought to have been attached to a bow-lance, a ceremonial weapon used in the nineteenth century by a number of groups.

Bowers also collected a number of antler tools, including a complete scraper handle and fragments of a choker, a wrist guard, and two unspecified tools. One of the
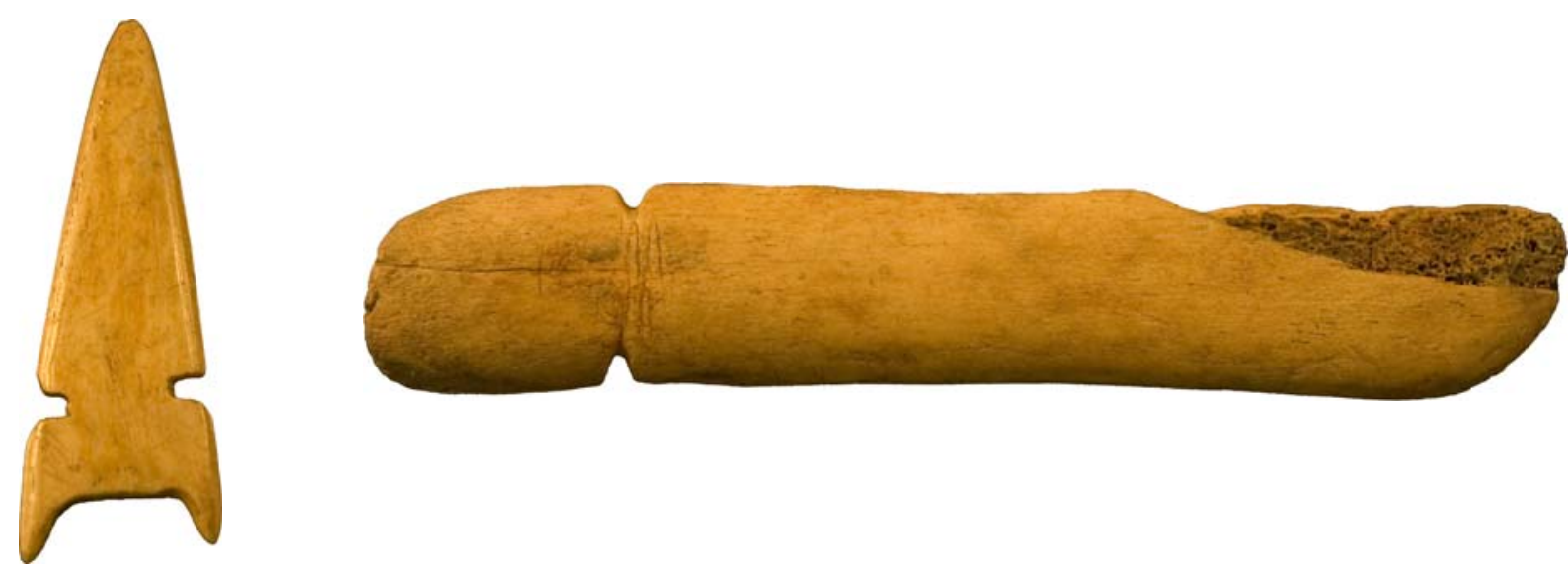

Figure 5.1. Bone tools from Larson Village. left: bow-lance tip (8 cm long); right: bison rib knife handle (14.5 cm long). 
unspecified tools consists of a tine fragment that may have been used as a pressure flaker, although evidence of use wear is limited. The other appears to have been an expedient knife.

\section{Stone Tools}

Table 5.2. Inventory of stone tools from Larson Village held by the Logan Museum of Anthropology.

\begin{tabular}{lcc}
\hline Technological Class & Frequency & Percent \\
\hline Patterned Small Biface & 28 & 8.4 \\
Patterned Large Biface & 87 & 26.0 \\
Unpatterned Biface & 7 & 2.1 \\
Scraper & 97 & 29.0 \\
Flake Tool & 24 & 7.2 \\
Large Bifacial Core-Tool & 4 & 1.2 \\
Freehand TRM & 47 & 14.0 \\
Freehand core & 4 & 1.2 \\
Bipolar Core/Tool & 1 & .3 \\
Unpatterned Ground Tool & 13 & 3.9 \\
Patterned Ground Tool & 17 & 5.1 \\
Retouched Plate & 6 & 1.8 \\
\hline Total & 335 & 100.0 \\
\hline
\end{tabular}

A total of 335 stone tools, divided into 17 numbered lots, occur in the collection (Table 5.2). Four additional lots consist of flaking debris, while one consists of a single, unmodified, rod-shaped pebble of moss agate. Stone tools in each lot were sorted by technological class and raw material. Artifacts made from Knife River flint (KRF) were further examined for evidence of burning and heat treatment. Ahler and others (1994) present descriptions of the relevant raw material types and technological classes. Data on the 2006 excavated sample from Larson can be found in Crawford and Mitchell (2007).

The proportions of various technological classes in Bowers's collection vary markedly from the 2006

excavated sample, and in fact are quite distinct from those of any systematically obtained Heart region assemblage. No doubt this is due largely to Bowers's haphazard collection methods; the small number of flake tools certainly reflects his interest in patterned tools, and especially in complete tools. However, the distribution also reflects the discovery of a flintknapper's cache on the floor of the lodge exposed in Work D (Bowers 1940). Along with five bone flaking tools and numerous nodules of raw material, the cache includes 34 scrapers, 16 knives, 11 arrowpoints, and one drill, all made from Knife River flint (KRF). It is clear that all of the cores and tested pieces in the collection derive from this cache (CN17386), as well as more than half of the scrapers made from KRF, several flakes, and other tools. However, most of the arrowpoints in the collection may come from other contexts at the site, because some are burned and others exhibit impact fractures or have been resharpened or recycled. The raw material pieces mainly consist of tabular cobbles and thin plates of moderate quality.

The Bowers collection differs from the 2006 collection in other ways, too. Compared to the 2006 excavated sample, many of the scraping tools in the Logan Museum sample are large and irregular, suggesting that they may have been unhafted and expedient. A number exhibit crushing and blunting use-wear indicative of contact with hard materials. Just over ten percent of the KRF tools in the Logan Museum collection are burned, compared to about one-third in the 2006 collection. Similarly, very few of the KRF tools received intentional heat treatment, with just one of 166 artifacts exhibiting certain evidence of heating. Another seven specimens probably were heat treated. The 2006 excavated sample demonstrates that flintknappers at Larson practiced heat 
treatment less frequently than flintknappers at other nearby villages, but even so the heat treatment rate exhibited by the Logan Museum collection is extremely low. Finally, Bowers’s stone tool assemblage also includes a Middle Archaic dart point made from KRF and a probable Late Archaic dart point made from gray chalcedony. By contrast, very few curated tools are present in the 2006 collection.

However, in other respects the Logan Museum sample mirrors the 2006 excavated sample. Table 5.3 presents data on the raw materials used to make the 305 chipped stone tools in the assemblage. About one-third of the tools were made from smooth gray Tongue River silicified sediment (TRSS). In the 2006 sample, just over 37 percent of the tools were made from TRSS. The Logan Museum sample also includes a large number of well made TRSS bifaces, many of them in the form of large, triangular knives. Although the 2006 collection contains only a few such artifacts, the presence of numerous TRSS biface thinning flakes attests indirectly to their production. Exotic materials are relatively uncommon in the Logan Museum sample, although they are somewhat better represented than in the 2006 sample. Particularly notable are five scrapers, two large bifaces, and two arrowpoints made from dendritic chert, probably from the Hartville Uplift in west-central Wyoming (Reher 1991).

Table 5.3. Stone tool technological classes organized by raw material type.

\begin{tabular}{|c|c|c|c|c|c|c|c|c|c|c|c|c|}
\hline \multirow[b]{2}{*}{ Material Type } & \multicolumn{11}{|c|}{ Technological Class } & \multirow[b]{2}{*}{ Total } \\
\hline & & 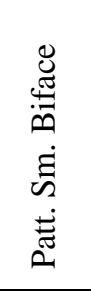 & 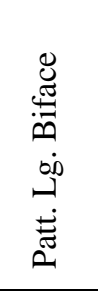 & 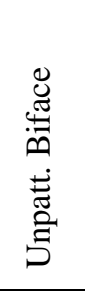 & 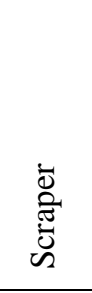 & $\begin{array}{l}\overrightarrow{8} \\
0 \\
0 \\
\ddot{0} \\
\frac{\pi}{\vec{I}} \\
\end{array}$ & 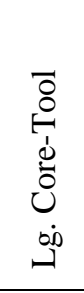 & 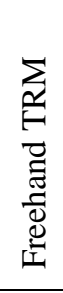 & 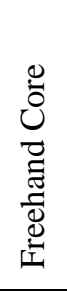 & 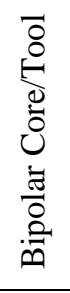 & 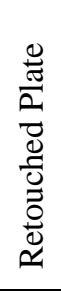 & \\
\hline \multirow[t]{2}{*}{ Smooth Gray TRSS } & $\mathrm{n}$ & 8 & 52 & 5 & 14 & 16 & & & & & & 95 \\
\hline & $\%$ & 28.6 & 59.8 & 71.4 & 14.4 & 66.7 & & & & & & 31.1 \\
\hline \multirow[t]{2}{*}{ Crs. Yellow TRSS } & $\mathrm{n}$ & 1 & & & & & 1 & & & & & 2 \\
\hline & $\%$ & 3.6 & & & & & 25.0 & & & & & .7 \\
\hline \multirow[t]{2}{*}{ Orthoquartzite } & $\mathrm{n}$ & & 3 & & & & & & & & & 3 \\
\hline & $\%$ & & 3.4 & & & & & & & & & 1.0 \\
\hline \multirow[t]{2}{*}{ Swan River Chert } & $\mathrm{n}$ & 1 & & & & & & & & & & 1 \\
\hline & $\%$ & 3.6 & & & & & & & & & & .3 \\
\hline \multirow[t]{2}{*}{ Jasper/Chert } & $\mathrm{n}$ & & 1 & & 3 & & & & & & & 4 \\
\hline & $\%$ & & 1.1 & & 3.1 & & & & & & & 1.3 \\
\hline \multirow[t]{2}{*}{ Dendritic Chert } & $\mathrm{n}$ & 1 & & & 5 & 1 & & & & & & 7 \\
\hline & $\%$ & 3.6 & & & 5.2 & 4.2 & & & & & & 2.3 \\
\hline \multirow[t]{2}{*}{ Clear/Gray Chal. } & $\mathrm{n}$ & 3 & 2 & 1 & 5 & & & & & & & 11 \\
\hline & $\%$ & 10.7 & 2.3 & 14.3 & 5.2 & & & & & & & 3.6 \\
\hline \multirow[t]{2}{*}{ Drk. Brn. Chal. } & $\mathrm{n}$ & & 1 & & 1 & & & & & & & 2 \\
\hline & $\%$ & & 1.1 & & 1.0 & & & & & & & .7 \\
\hline
\end{tabular}


Table 5.3. Stone tool technological classes organized by raw material type, concluded.

\begin{tabular}{|c|c|c|c|c|c|c|c|c|c|c|c|c|}
\hline \multirow[b]{2}{*}{ Material Type } & \multicolumn{11}{|c|}{ Technological Class } & \multirow[b]{2}{*}{ Total } \\
\hline & & 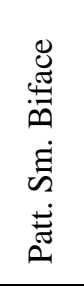 & 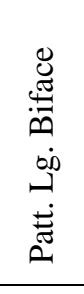 & 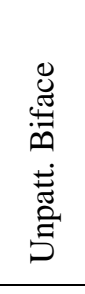 & $\begin{array}{l}\overrightarrow{\tilde{\Xi}} \\
\text { ज्ञّ } \\
\text { 心 }\end{array}$ & 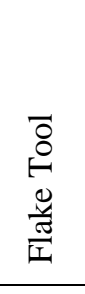 & 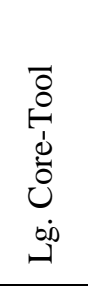 & 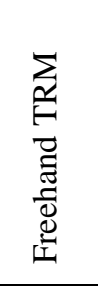 & 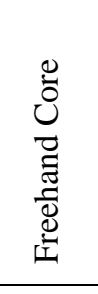 & 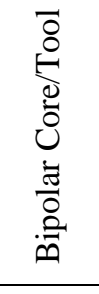 & 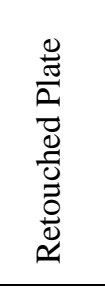 & \\
\hline \multirow[t]{2}{*}{ Plate Chal. } & $\mathrm{n}$ & 1 & & & & & & & & & & 1 \\
\hline & $\%$ & 3.6 & & & & & & & & & & .3 \\
\hline \multirow[t]{2}{*}{ Basaltic } & $\mathrm{n}$ & & & & & 1 & 1 & & & & & 2 \\
\hline & $\%$ & & & & & 4.2 & 25.0 & & & & & .7 \\
\hline \multirow[t]{2}{*}{ Knife River Flint } & $\mathrm{n}$ & 11 & 27 & 1 & 63 & 6 & & 47 & 4 & 1 & 6 & 166 \\
\hline & $\%$ & 39.3 & 31.0 & 14.3 & 64.9 & 25.0 & & 100.0 & 100.0 & 100.0 & 100.0 & 54.4 \\
\hline \multirow[t]{2}{*}{ Silicified Wood } & $\mathrm{n}$ & 1 & 1 & & 6 & & & & & & & 8 \\
\hline & $\%$ & 3.6 & 1.1 & & 6.2 & & & & & & & 2.6 \\
\hline \multirow[t]{2}{*}{ Moss Agate } & $\mathrm{n}$ & 1 & & & & & & & & & & 1 \\
\hline & $\%$ & 3.6 & & & & & & & & & & .3 \\
\hline \multirow[t]{2}{*}{ Schist } & $\mathrm{n}$ & & & & & & 2 & & & & & 2 \\
\hline & $\%$ & & & & & & 50.0 & & & & & .7 \\
\hline Total & $\mathrm{n}$ & 28 & 87 & 7 & 97 & 24 & 4 & 47 & 4 & 1 & 6 & 305 \\
\hline
\end{tabular}

The Logan Museum collection includes 13 diorite celts (Figure 5.2). By contrast, fragments of only 6 such tools were recovered from Double Ditch Village during the extensive 2002-2004 field investigations. None occur in the very large stone tool sample from Scattered Village (Ahler et al. 2002). Interestingly, the 2006 flaking debris sample from Larson includes an unusually large number of diorite flakes (coded incorrectly during the original analysis as "basaltic material"), suggesting that some of the residents may have been engaged in celt manufacturing. Other patterned groundstone artifacts in the Bowers collection include two net sinkers, and two incised gaming pieces. Unpatterned groundstone tools include one sandstone shaft abrader, and 12 hammerstones made from various materials. One of the hammerstones (CN17107.9) was also used as an anvil, probably for the production of bipolar tools.

Figure 5.2. One of 13 diorite celts in the Larson Village collection at the Logan Museum (CN17093.12).

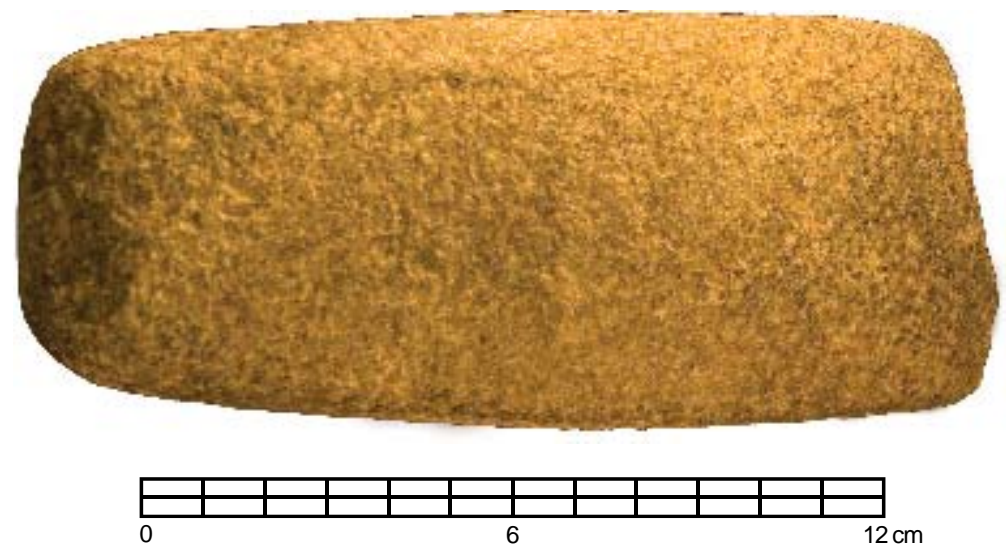




\section{Pottery}

Pottery from Larson Village in the Logan Museum collection occurs in 13 numbered lots. One of these (CN 17102) consists of a single detached lug exhibiting cord impressions. Two others (CN 2006.02.001 and CN 2006.14.004) consist almost entirely of body sherds. The remaining ten lots are made up of rim sherds, along with a few neck sherds and miscellaneous rim and lip fragments, which have been roughly organized into typological groups. For this analysis, sherds in each of these ten lots were sorted first by rim form, then by ware and variety, and finally by dominant decorative technique. No metric data were recorded. Heart region pottery types are discussed in Ahler (2001) and Ahler and others (2002). Data on the ceramic remains recovered from Larson in 2006 are presented in Mitchell and others (2007).

Refitting sherds (and, in a few cases, obvious matches that nevertheless did not refit directly) were grouped into "vessels." Several rims are nearly complete. Efforts to refit or match rim sherds were confined to within-catalog number comparisons; however, sherds from two or three vessels exhibiting striking forms or unusual decorative techniques were recognized in different catalog numbers. In these cases, matched sherds were counted as a single vessel, but kept with their respective lots. Systematic analysis of the collection likely would result in the discovery of additional refits and matches, reducing the number of identified vessels.

Table 5.4 presents rim form data on 348 vessels in the Bowers collection, along with

Table 5.4. Comparison of rim form frequencies in the Logan Museum and 2006 PCRG samples from Larson Village.

\begin{tabular}{lcccc}
\hline & \multicolumn{2}{c}{ Logan Museum } & \multicolumn{2}{c}{ 2006 PCRG } \\
\cline { 2 - 5 } Rim Form & $n$ & $\%$ & $n$ & $\%$ \\
\hline 1 lip & 1 & .3 & & \\
2 bowl or jar & 4 & 1.1 & 2 & .4 \\
3 straight rim & 9 & 2.6 & 23 & 4.6 \\
4 straight rim w/brace & 48 & 13.8 & 76 & 15.1 \\
7 s-rim & 62 & 17.8 & 137 & 27.3 \\
8 s-rim w/brace & 39 & 11.2 & 5 & 1.0 \\
11 recurved s-rim & 13 & 3.7 & 7 & 1.4 \\
12 recurved s-rim w/brace & 5 & 1.4 & & \\
15 zone 2-3 frag. & 35 & 10.1 & 161 & 32.1 \\
16 zone 2-3 frag. w/brace & 1 & .3 & & \\
20 zone 3 frag. & 5 & 1.4 & 44 & 8.8 \\
24 s-rim w/int. brace & 92 & 26.4 & 45 & 9.0 \\
25 recurved s-rim w/int. brace & 26 & 7.5 & 2 & .4 \\
27 lip fragment w/int. brace & 6 & 1.7 & & \\
28 s-rim w/int. and ext. brace & 2 & .6 & & \\
\hline Total & 348 & 100.0 & 502 & 100.0 \\
\hline
\end{tabular}

as common in the Bowers collection as it is in the 2006 sample. Exterior bracing is ten times as comparable data on 502 vessels in the 2006 collection. The Logan Museum sample includes relatively few zone 2 or zone 3 fragments (i.e. sherds classified as rim form 15 or 20), no doubt reflecting Bowers's collection strategy as well as more recent attempts to sort the collection. Generally, when standardized sorting methods are applied, one-fifth to one-third of rim sherd assemblages from Heart region sites consists of fragments. It seems likely that the large lot of unanalyzed body sherds in the Bowers collection (CN 2006.02.001) includes a number of zone 2 and zone 3 fragments. More substantively, the Bowers collection includes a much higher proportion of braced S-rim vessels. Interior bracing (on S-rims and recurved S-rims) is more than three times 
Table 5.5. Comparison of ware frequencies in the Logan Museum and 2006 PCRG samples from Larson Village.

\begin{tabular}{lcccc}
\hline & \multicolumn{2}{c}{ Logan Museum } & \multicolumn{2}{c}{2006 PCRG } \\
Ware & $n$ & $\%$ & $n$ & $\%$ \\
\hline Unnamed Str. Rim & 18 & 6.0 & 13 & 4.4 \\
Stanton & 1 & .3 & 12 & 4.1 \\
Unnamed S-Rim & 7 & 2.3 & 19 & 6.4 \\
Sanger & 2 & .7 & 4 & 1.4 \\
LeBeau & 206 & 68.7 & 165 & 55.9 \\
Knife River & 42 & 14.0 & 68 & 23.1 \\
Knife River Fine & & & 3 & 1.0 \\
Transitional & 24 & 8.0 & 2 & .7 \\
S-rim & & & 6 & 2.0 \\
Le Beau Fine & & & 3 & 1.0 \\
\hline Total & 300 & 100.0 & 295 & 100.0 \\
\hline
\end{tabular}

common. No recurved S-rim vessels with exterior bracing are present in the 2006 sample.

The proportions of various wares also are notably different (Table 5.5). Although Le Beau ware dominates both, the 2006 assemblage is more diverse and includes several fifteenth or early sixteenth century wares, such as Stanton ware and Sanger ware. Transitional ware is four times as common in the Bowers collection. Differences also are apparent within the two most common types, Le Beau ware and Knife River ware. Table 5.6 presents a breakdown and comparison of Le Beau ware vessels. Just over 85 percent of the 2006 collection consists of Le Beau Classic vessels. By contrast, the Logan Museum collection includes a diverse range of Le Beau ware vessels. Of particular interest is the presence of Le Beau Sperry variety vessels, a distinctive horizon style that appeared in the second half of the seventeenth century.

The frequencies of different decorative technique applied to Knife River ware vessels also differ between the two assemblages (Table 5.7). In the 2006 sample, more than one-third of the Knife River ware vessels bear tool impressed decoration on the brace, while only about one-fifth of the Logan Museum vessels do.

Table 5.6. Comparison of Le Beau ware varieties in the Logan Museum and 2006 PCRG samples from Larson Village.

\begin{tabular}{lcccc} 
& \multicolumn{2}{c}{ Logan Museum } & \multicolumn{2}{c}{ 2006 PCRG } \\
Variety & $n$ & $\%$ & $n$ & $\%$ \\
\hline Classic & 102 & 49.5 & 139 & 85.3 \\
T-lip & 2 & 1.0 & 3 & 1.8 \\
Recurved & 47 & 22.8 & 11 & 6.7 \\
Sperry & 10 & 4.9 & & \\
Sperry Recurved & 1 & .5 & & \\
High Rim & 22 & 10.7 & & \\
Paddled & 6 & 2.9 & & \\
Plain & 16 & 7.8 & 7 & 4.3 \\
Fine & & & 3 & 1.8 \\
\hline Total & 206 & 100.0 & 163 & 100.0 \\
\hline
\end{tabular}

Taken together, these differencesin rim form, ware and variety, and decorative technique-indicate that the Logan Museum collection is younger than the 2006 sample. At On-A-Slant and Scattered villages on the west bank of the Missouri, well-made recurved S-rim vessels like those in the Bowers collection (Figure 5.3) were especially common during the late 1500 s and early 1600 s. At Double Ditch Village, Le Beau Sperry ware first appears during the second half of the 1600s. Throughout the Heart region, Transitional ware increases in frequency during the 1600s.

The differences between the Logan Museum sample and the 2006 samples suggest that the attempt during the 2006 fieldwork to target the earliest deposits at the site was 
Table 5.7. Comparison of decorative techniques used on Knife River ware vessels in the Logan Museum and 2006 PCRG samples from Larson Village.

\begin{tabular}{|c|c|c|c|c|c|}
\hline \multirow[b]{2}{*}{ Sample } & \multicolumn{4}{|c|}{ Dominant Decorative Technique } & \multirow[b]{2}{*}{ Total } \\
\hline & Plain & Cord Impressed & Tool Impressed & Unclassifiable & \\
\hline \multirow{2}{*}{ Logan Museum } & 1 & 31 & 9 & 1 & 42 \\
\hline & $2.3 \%$ & $73.8 \%$ & $21.4 \%$ & $2.3 \%$ & \\
\hline \multirow[t]{2}{*}{2006 PCRG } & & 42 & 26 & 3 & 71 \\
\hline & & $59.2 \%$ & $36.6 \%$ & $4.2 \%$ & \\
\hline Total & 1 & 73 & 35 & 4 & 113 \\
\hline
\end{tabular}

largely successful. Although specific provenience data have been lost for the Logan Museum collection, most of Bowers's excavation units were located between Ditch 1 and the outer ring of midden mounds. If it is the case that the settlement contracted progressively over time, then Bowers must have primarily sampled deposits dating to the seventeenth and eighteenth centuries and in fact the pottery in the collection dates mainly to that period. The content of the Logan Museum collection therefore lends support to the hypothesis that the village was occupied continuously from the late 1400 s or early 1500 s until the late 1700 s.

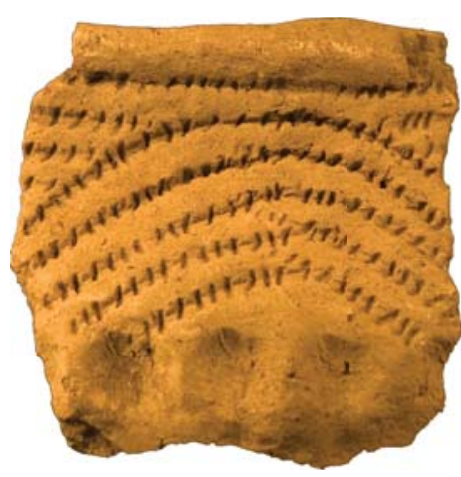

a

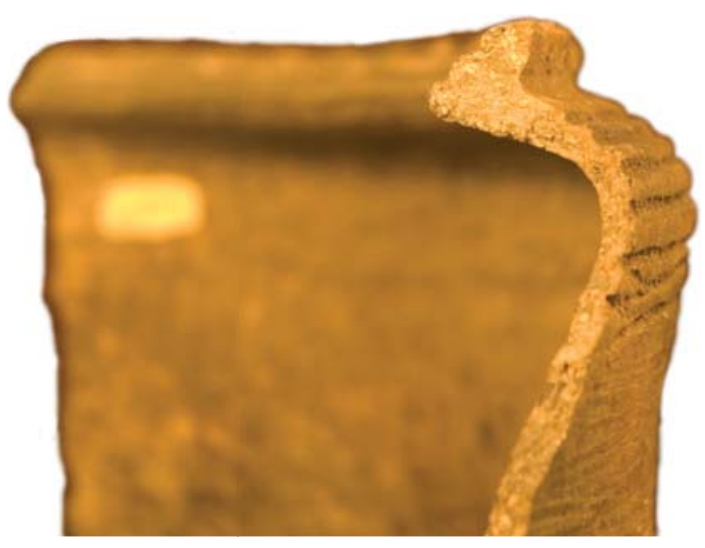

C
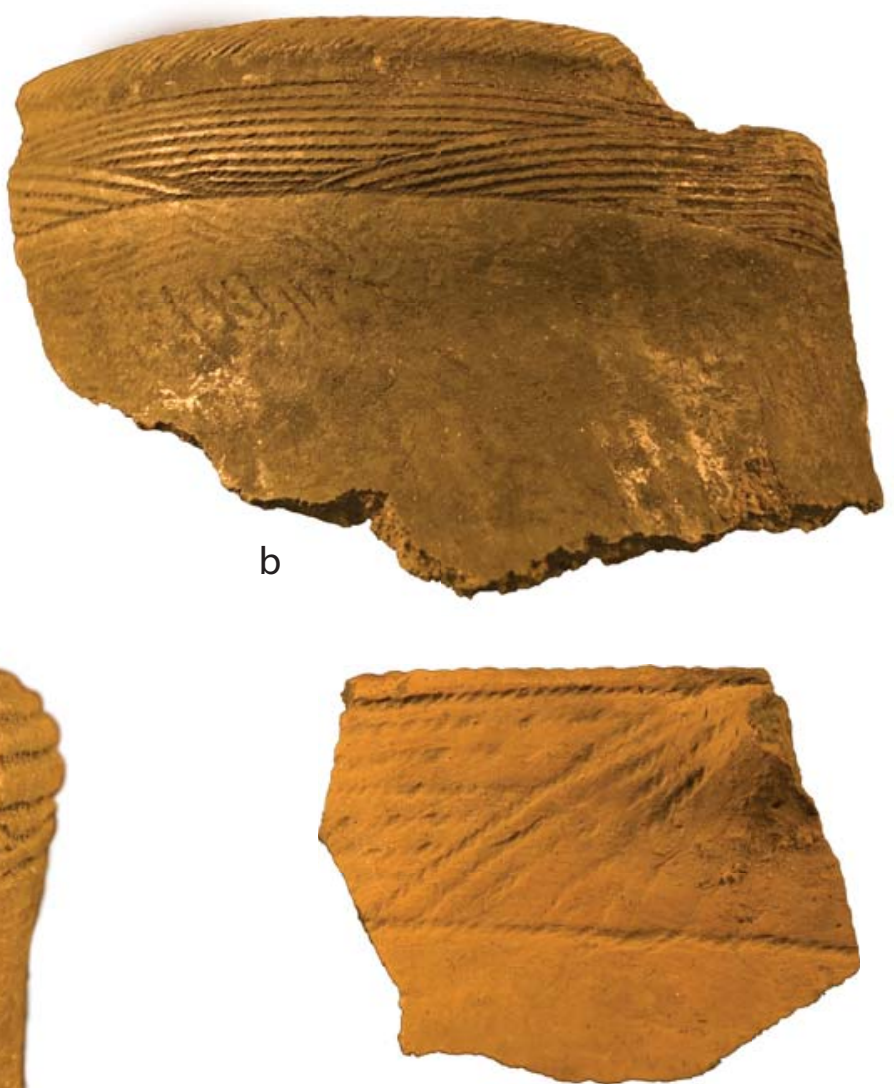

d

Figure 5.3. Selected rim sherds from the Logan Museum collection from Larson Village. a, d: imported vessels; b, c: Le Beau Recurved variety vessels. Scale varies. 
The Logan Museum pottery sample also includes a small number of vessels indicative of long-distance trade (Figure 5.3). One vessel bears cord-wrapped rod decoration on a recurved S-rim form. The other is an S-rim vessel with tool impressions in a herringbone pattern on the lip and somewhat haphazardly applied cord impressions on zone 3. Both exhibit the technological characteristics of late, northern Extended Coalescent pottery (Johnson 2007; Lehmer 1971). Both vessels are thin-walled and were manufactured from sparsely tempered paste. Both were fired in an oxidizing atmosphere. Another possible import vessel was noted in the 2006 collection (Mitchell et al. 2007:Figure 7.1e). Similar imports have been documented at Huff Village, a large mid-fifteenth century settlement located on the west bank of the Missouri (Wood 1967:106, 136) and at On-ASlant Village, a west bank village contemporaneous with Larson (Speakman et al.:1997:Figure 40a). Interestingly, Extended Coalescent ceramic assemblages commonly include braced straight-rim vessels bearing tool impressed decoration. The presence of these kinds of vessels is a notable feature of the 2006 Larson sample. The Huff Village assemblage also includes a significant number of such vessels (Wood 1967:69).

\section{State Historical Society of North Dakota Collection}

Tables 5.8 through 5.10 provide an inventory of artifacts from Larson Village held by the SHSND. The "Shelf Location" column in each table gives a three-part code describing where the items can be found in the SHSND repository. The first term refers to the row number (R), the second refers to the column letter and shelf number $(C+S)$, and the third, if applicable, refers to the box number (B). The majority of these specimens were obtained by private individuals, whose collections later were donated to the state of North Dakota. Table 5.8 lists four such collections. The single largest collection was made by Ralph Thompson (Table 5.9). In addition to pottery, stone tools, and other items, Thompson recovered a number of trade artifacts from the site. He also published research on the site, proposing that it may have been the Mandan community visited by the French trader and explorer Pierre Gaultier de Varennes, Sieur de la Verendrye, in 1738 (Swenson 2007; Thompson 1984). Thompson was interested in public education and included artifacts from Larson, along with items from other sites, in small display cases, known as "Riker mounts." Thompson's collection is currently on long-term loan to the SHSND and has not yet been accessioned. Table 5.9 is organized according to Rod Thompson's inventory system, which was assigned at the time of the loan agreement.

Table 5.8. List of small artifact collections from Larson Village held by the SHSND.

\begin{tabular}{lcc}
\hline Accession Number & Name & Shelf Location (R/C+S/B) \\
\hline 82.117 & Kamarasky Collection & $9 / \mathrm{J} 8 / 1$ \\
Multiple & E. R. Steinbrueck Collection & 8/B4/3 \\
95.3, 95.4, 95.5 & Dana Wright Collection & $9 / \mathrm{J} 2 / 1$ \\
Multiple; Unaccessioned & W. D. Powell Collection & 9/J3/2 \\
\hline
\end{tabular}

The third group of items, listed in Table 5.10, includes artifacts excavated by SHSND archaeologists, as well as unaccessioned lots from a variety of sources. Together, these materials amount to portions of 11 boxes of material.

Most of the items held by the SHSND remain unstudied. However, two projects have examined elements of the collection. Ahler (2001) describes 108 pottery rims from two lots 
collected in 1975 by SHSND archaeologists (Accession Nos. 75.36 and 75.138) and 97 stone tools drawn from nine lots, including one unaccessioned lot. The ceramic data include rim form, ware, subware, and the shapes of zones 3, 5, and 7. Metric data, including number of parallel cords, cord spacing, and cord diameter, were collected on 31 vessels. For the stone tools, data on raw material type and technological class were collected. Ahler (2001:18) observes that the ceramic sample contains many large vessels exhibiting coarse decoration, making it distinct from pottery from Slant, Sperry, or Scattered villages but similar to pottery from Lower Hidatsa and Big Hidatsa villages in the Knife region.

Table 5.9. List of artifacts from Larson Village in the Ralph Thompson Collection.

\begin{tabular}{|c|c|c|}
\hline Description & $\begin{array}{c}\text { Thompson } \\
\text { Number }\end{array}$ & $\begin{array}{c}\text { Shelf Location } \\
(\mathrm{R} / \mathrm{C}+\mathrm{S} / \mathrm{B})\end{array}$ \\
\hline Modified bone; ceramics & 77 & $17 / \mathrm{F} 7$ \\
\hline Ground stone tools; misc. & 83 & 17/F3 \\
\hline Ground stone tools; misc. & 84 & 17/G1 \\
\hline Miscellaneous & 99 & 17/H8 \\
\hline Miscellaneous & 151 & $17 / \mathrm{I} 5$ \\
\hline Miscellaneous & 157 & $17 / \mathrm{I} 7 / 1$ \\
\hline Ceramics & 172 & 17/E6 \\
\hline Riker mount & 182 & $17 / \mathrm{D} 7$ \\
\hline Riker mount & 183 & 17/D7 \\
\hline Riker mount & 186 & 17/D7 \\
\hline Riker mount & 188 & 17/D7 \\
\hline Riker mount & 192 & 17/D7 \\
\hline Riker mount & 196 & 17/D6 \\
\hline Riker mount & 197 & 17/D6 \\
\hline Riker mount & 198 & 17/D6 \\
\hline Riker mount & 199 & 17/D6 \\
\hline Riker mount & 200 & 17/D7 \\
\hline Riker mount & 202 & 17/D6 \\
\hline Riker mount & 217 & $17 / \mathrm{D} 7$ \\
\hline Educational display & 357 & $17 / \mathrm{I} 5 / 3$ \\
\hline Chipped stone tools; misc. & 359 & $17 / \mathrm{I} 7 / 2$ \\
\hline Ground stone tools & 360 & $17 / \mathrm{I} 8 / 1$ \\
\hline Educational display & 368 & $17 / \mathrm{I} 4 / 3$ \\
\hline Educational display & 369 & $17 / \mathrm{I} 5 / 1$ \\
\hline
\end{tabular}

Table 5.10. List of miscellaneous artifact collections from Larson Village held by the SHSND.

\begin{tabular}{lc}
\hline Accession Number & Shelf Location (R/C+S/B) \\
\hline Unaccessioned & $6 / \mathrm{I} 1 / 1$ \\
Unaccessioned & $6 / \mathrm{I} 1 / 2$ \\
Multiple; Unaccessioned & $6 / \mathrm{I} 1 / 3$ \\
Unaccessioned & $6 / \mathrm{I} 2 / 1$ \\
Unaccessioned & $6 / \mathrm{I} 2 / 2$ \\
Unaccessioned & $6 / \mathrm{I} 2 / 3$ \\
Multiple; Unaccessioned & $6 / \mathrm{J} 8 / 1$ \\
Multiple; Unaccessioned & $6 / \mathrm{J} 8 / 2$ \\
Unaccessioned & $9 / \mathrm{E} 4 / 1$ \\
Multiple & $9 / \mathrm{H} 7 / 1$ \\
Multiple & $9 / \mathrm{I} 4 / 1$ \\
\hline
\end{tabular}


A second study examines a sample of bone tools from the site. Griffitts (2006) uses morphological and use-wear data on a variety of tool types from Larson and four other sites in the northern Middle Missouri to investigate changing patterns of production and use that accompanied the advent of Europeans and European technologies. Griffitts concludes that the observed patterns of change do not fit the commonly held model which maintains that bone tools were immediately and entirely replaced by metal tools. Rather, the introduction of European technologies initiated a period of productive experimentation, which resulted in the development of new bone tool forms and new manufacturing techniques. 


\section{References Cited}

Ahler, Stanley A.

2001 Analysis of Curated Plains Village Artifact Collections from the Heart, Knife, and Cannonball Regions, North Dakota. Research Contribution No. 42. PaleoCultural Research Group, Flagstaff, Arizona. Submitted to the State Historical Society of North Dakota, Bismarck.

2005 Modified Bone and Antler Artifacts. In Archaeological Investigations During 2004 at Double Ditch State Historic Site, North Dakota, edited by Stanley A. Ahler, pp. 259-280. Research Contribution No. 65. PaleoCultural Research Group, Flagstaff, Arizona. Submitted to the State Historical Society of North Dakota, Bismarck.

Ahler, Stanley A. (editor)

1994 A Working Manual for Field and Laboratory Techniques and Methods for the 1992-1996 Lake Ilo Archaeological Project. Quaternary Studies Program, Northern Arizona University, Flagstaff, Arizona. Submitted to the U.S. Fish and Wildlife Service, Denver, Colorado.

Ahler, Stanley A., and Gail Ryser

1997 Modified Bone and Antler. In Archaeology of the Mandan Indians at On-A-Slant Village (32MO26), Fort Abraham Lincoln State Park, Morton County, North Dakota, edited by Stanley A. Ahler, pp. 351-390. Office of Research and Graduate Studies, Northern Arizona University. Submitted to North Dakota Parks and Recreation Department, Bismarck.

Ahler, Stanley A., and Carl R. Falk

2002 Modified Bone and Antler Remains. In Prehistory on First Street NE: The Archaeology of Scattered Village in Mandan, North Dakota, edited by Stanley A. Ahler, pp. 13.1-13.45.

Research Contribution No. 40. PaleoCultural Research Group, Flagstaff, Arizona.

Submitted to the City of Mandan, Mandan, North Dakota, and the North Dakota Department of Transportation, Bismarck.

Ahler, Stanley A., Vince Warner, and Monicque Smail

2002 Pottery Analysis. In Prehistory on First Street NE: The Archaeology of Scattered Village in Mandan, North Dakota, edited by Stanley A. Ahler, pp. 11.1-11.88. Research

Contribution No. 40. PaleoCultural Research Group, Flagstaff, Arizona. Submitted to the City of Mandan, Mandan, North Dakota, and the North Dakota Department of Transportation, Bismarck.

Ahler, Stanley A., Eric Feiler, Chad Badorek, and Monicque Smail

2002 Stone Tools and Flaking Debris. In Prehistory on First Street NE: The Archaeology of Scattered Village in Mandan, North Dakota, edited by Stanley A. Ahler, pp. 12.1-12.81. Research Contribution No. 40. PaleoCultural Research Group, Flagstaff, Arizona. Submitted to the City of Mandan, Mandan, North Dakota, and the North Dakota Department of Transportation, Bismarck.

Bowers, Alfred W.

1940 Missouri River Earthlodge Archaeology of North Dakota and South Dakota. Ms. on file at the Logan Museum of Anthropology, Beloit College, Beloit, Wisconsin.

Crawford, George T., and Mark D. Mitchell

2007 Modified Stone Analysis. In Geophysical Survey and Test Excavation During 2006 at Larson Village, Burleigh County, North Dakota, edited by Mark D. Mitchell, pp. 141-173. 
Research Contribution No. 80. PaleoCultural Research Group, Flagstaff, Arizona. Submitted to the State Historical Society of North Dakota, Bismarck.

Falk, Carl R.

2007 Modified Bone and Antler Artifacts. In Geophysical Survey and Test Excavation During 2006 at Larson Village, Burleigh County, North Dakota, edited by Mark D. Mitchell, pp. 177-193. Research Contribution No. 80. PaleoCultural Research Group, Flagstaff, Arizona. Submitted to the State Historical Society of North Dakota, Bismarck.

Green, William, Amelia R. Hubbard, and Margretta S. Meyer

2002 Inventory and Preliminary Analysis of Archaeological Collections from Alfred W. Bowers Field Work Along the Missouri River, 1929-1931. Paper presented at the $60^{\text {th }}$ Plains Anthropological Conference, Oklahoma City.

Griffitts, Janet L.

2006 Bone Tools and Technological Choice: Change and Stability on the Northern Plains. Unpublished Ph.D. dissertation, Department of Anthropology, University of Arizona, Tucson.

Johnson, Craig M.

2007 A Chronology of Middle Missouri Plains Village Sites. Contributions to Anthropology No. 47. Smithsonian Institution, Washington, D. C.

Lehmer, Donald J.

1971 Introduction to Middle Missouri Archaeology. Anthropological Papers No. 1. USDI National Park Service, Washington, D. C.

Mitchell, Mark D., Stacey Madden, and Stanley A. Ahler

2007 Pottery Analysis. In Geophysical Survey and Test Excavation During 2006 at Larson Village, Burleigh County, North Dakota, edited by Mark D. Mitchell, pp. 107-140. Research Contribution No. 80. PaleoCultural Research Group, Flagstaff, Arizona. Submitted to the State Historical Society of North Dakota, Bismarck.

Reher, Charles A.

1991 Large Scale Lithic Quarries and Regional Transport Systems on the High Plains of Eastern Wyoming: Spanish Diggings Revisited. In Raw Material Economies Among Prehistoric Hunter-Gatherers, edited by Anta Montet-White and Steven Holen, pp. 251-284.

Publications in Anthropology No. 19. University of Kansas, Lawrence.

Speakman, Robert J., Stanley A. Ahler, and Kim Breakey

1997 Pottery. In Archaeology of the Mandan Indians at On-A-Slant Village (32MO26), Fort Abraham Lincoln State Park, Morton County, North Dakota, edited by Stanley A. Ahler, pp. 351-390. Office of Research and Graduate Studies, Northern Arizona University. Submitted to North Dakota Parks and Recreation Department, Bismarck.

Swenson, Fern E.

2007 Previous Investigations at Larson Village. In Geophysical Survey and Test Excavation During 2006 at Larson Village, Burleigh County, North Dakota, edited by Mark D. Mitchell, pp. 11-25. Research Contribution No. 80. PaleoCultural Research Group, Flagstaff, Arizona. Submitted to the State Historical Society of North Dakota, Bismarck. Thompson, Ralph S.

1984 The Site of the Mandan Indian Village Visited by Verendrye in 1738: A New Look. North Dakota History 51(4):22-28.

Wood, W. Raymond

1967 An Interpretation of Mandan Culture History. Smithsonian Institution, Bureau of American Ethnology Bulletin 198. River Basin Surveys Papers No. 39. U.S. Government Printing Office, Washington, D. C. 


\title{
6. SUMMARY AND RECOMMENDATIONS
}

\author{
Mark D. Mitchell
}

The Larson Village project is one component of a larger effort to understand the history of the Heart River region. Archaeological research has been carried out sporadically in the region for more than a century, but the last decade has witnessed a focused and sustained effort by the State Historical Society of North Dakota and its partners to investigate post-1500 culture change there. This work began fortuitously in 1998 with the inadvertent discovery of Scattered Village beneath the City of Mandan (Ahler, ed. 2002). Prior to that time, empirical data from well-controlled excavations were available only for one of the Heart River towns, On-A-Slant Village (Ahler, ed. 1997). The Scattered Village project demonstrated for the first time that significant differences existed among contemporaneous communities in the Heart region. Despite their proximity—just 10 $\mathrm{km}$ - the material content of Scattered Village is quite distinct from that of Slant Village, whether measured by pottery types or by stone tool raw material or technology.

As the Scattered Village project drew to a close, the SHSND, working with PCRG and the Archeo-Imaging Lab at the University of Arkansas initiated research at Double Ditch State Historic Site, likely the largest and certainly the best preserved of the Heart River towns. Over the course of four field seasons from 2001 to 2004, the research team explored the site using state-of-the-art geophysical techniques combined with targeted, problem-oriented test excavations (Ahler, ed. 2003, 2004, 2005; Kvamme and Ahler 2007). This work documented the remarkably complex occupational history of the village, revealed previously-unsuspected features of the settlement, and offered a glimpse of the dynamic processes that shaped the settlement during its 300-year period of occupation. It also confirmed the conclusion reached by the Scattered Village project that the large communities near the Heart River differed from one another in important ways.

In 2005, the team moved to Boley Village, a little-known west bank settlement (Ahler, ed. 2006). Unlike Double Ditch, Boley has been severely impacted by cultivation, road and railroad construction, and recent development. However, by again combining geophysical surveys with targeted test excavations, significant new discoveries were made about the age and history of the site. In contrast to Double Ditch, where the settlement contracted progressively over time, Boley appears to have been reconstructed with substantial reorientation late in its history. Thus, not only did the material content of the Heart region villages differ, but their occupational histories did as well.

The work at Larson was guided by the results obtained at Scattered, Double Ditch, and Boley villages. To insure comparability of the data collected, the field and laboratory methods used at Larson mirrored as closely as possible those of earlier projects. Because the project's principal research questions focused on the age of the settlement, much of the initial field effort in 2006 focused on the comparatively featureless area north of the northernmost perimeter mounds. Based on research at Double Ditch and Boley, the team believed that this would be the best place to obtain a clear view of the settlement's earliest features. During 2007, fieldwork focused to a greater degree on the central and southern portions of the site, especially the most-recently occupied sector of the village, inside Ditch 1. Based on the results of this two-year effort it is now possible to 
answer key questions about Larson Village and its history. This chapter outlines the principal research questions that guided these investigations, summarizes the project's major findings, and makes recommendations for future work at the site.

\section{Research Goals}

The research team sought to explore four principle topics: chronology and occupational history; settlement layout and extent; material content comparisons; and formation processes. Both Indian and European historical accounts fix the abandonment of the Heart region in the 1780s, but until recently no one knew when the major Heart River towns were first established. Work at Double Ditch demonstrated that it likely was founded in the late 1400s. Scattered Village and Boley Village appear to have been founded about a century later. As noted above, these projects also demonstrated that the occupational histories of the Heart River towns varied. At Double Ditch, geophysical and other data show that four concentric fortification systems were built around the community. Dates for these features, established by a combination of radiocarbon dating, trade artifact density analysis, and stratigraphic correlation, indicate that the outermost is likely the oldest and that the innermost is the youngest. Thus, the village diminished in size over time, with a peak population at the time the village was founded in the late 1400s and with a minimal population and size right before abandonment in the AD 1780s. By contrast, at Boley the two outermost fortifications are not concentric, but rather cross one another. Along with ceramic evidence, these data indicate that the village was substantially rebuilt and reoriented, probably in the late 1600s or early 1700s. The magnitude of the shift further suggests that the two occupations of the village may have been interrupted by a hiatus of unknown duration. Radiocarbon dates and ceramic analysis indicate that the oldest sampled features, including one of the fortification ditches, may not be quite as old as the oldest features at Double Ditch, possibly indicating that the village was founded in the late 1500 s or early 1600 s. Thus, two key goals of the Larson Village project have been to determine when the settlement was founded and to ascertain whether it contracted progressively like Double Ditch or whether it was rebuilt and reoriented like Boley.

Work at Larson also focused on mapping the site and determining its maximum extent. Several of the site's most prominent features have been recognized for more than a century. The maps drawn by George Will and Herbert Spinden and by Alfred Bowers accurately depict the high mounds ringing the perimeter of the site, the broad central plaza, and the prominent fortification ditch encircling the center of the village. However, work at Double Ditch and Boley has demonstrated that both of those settlements extend far beyond the limits of the visible surface features. These projects have also revealed the presence of previously unsuspected features, especially unseen fortification systems. Accordingly, the field investigations at Larson have attempted to locate the boundaries of the settlement and inventory its major features.

Studies of pottery, stone and bone tools, and other materials have been carried out with an eye to comparisons between Larson Village and the other Heart River towns. As work in the region has progressed, it has become clear that the material content of each community differed in important ways from that of its neighbors. Such material differences may reflect social distinctions or local economic practices, but in any case they suggest that the relationships among contemporaneous communities were complex and dynamic. The Larson Village research team has been particularly interested in comparisons with Double Ditch. It is clear that the two towns share a 
number of features and the team wanted to know whether those similarities were matched by material parallels.

As the lab work progressed, it became clear that the Larson collection differed in several ways from other Heart region collections. Specifically, the pottery assemblage appeared to be more fragmented and the diversity and richness of the bone and stone tool assemblages appeared to be comparatively low. To investigate the nature and possible causes of these differences, analysis focused in part on characterizing site formation processes. Density comparisons among various deposit types were of particular interest.

In addition to these research themes, the team also pursued site management goals. Perhaps the most basic aspect of this work involved accurately determining the boundaries of the site. But the team also wanted to assess the current condition of cultural deposits in various parts of the site and establish a baseline against which long-term changes could be measured.

\section{Project Results}

This section summarizes the major findings of the Larson Village project. The discussion is organized around five topics: the major features of the site, the extent and condition of cultural deposits, site formation processes, the chronology and occupational history of the settlement, and material comparisons.

\section{Major Features}

Together, the geophysical and topographic surveys, excavation, and hand coring carried out in 2006 and 2007 documented a variety of previously unsuspected features (Figure 6.1). The most significant result is the discovery that the site is in fact surrounded by a complex sequence of at least four concentric fortification systems. The outermost, designated Ditch 4, is located well beyond the settlement's halo of high midden mounds and includes at least two projecting bastions. Another bastion may be a part of Ditch 4 or of Ditch 3, a second fortification system nested inside Ditch 4. Neither of these features is expressed on the surface. Ditch 2, which winds through the center of the village, is intermittently visible as a shallow depression up to $30 \mathrm{~cm}$ deep. The track of Ditch 2 is better expressed on the magnetic map, where it appears as a distinct linear anomaly. Ditch 1 surrounds the inner core of the village and is clearly visible both topographically and magnetically along its entire length. In addition to these four ditch features, the presence of several additional short segments suggests that the history of the site's fortifications is complex.

In 2006, two small test units were placed over Ditches 3 and 4 to explore their form and sample their content. They are similar in form, but were filled with different types of deposits. The strata filling Ditch 4 are thick and relatively homogeneous, suggesting that it was abandoned and filled intentionally. By contrast, the strata in Ditch 3 consist mainly of thin silt laminae, sandwiched between thicker layers of domestic refuse mixed with sediment, suggesting that it filled more gradually. 


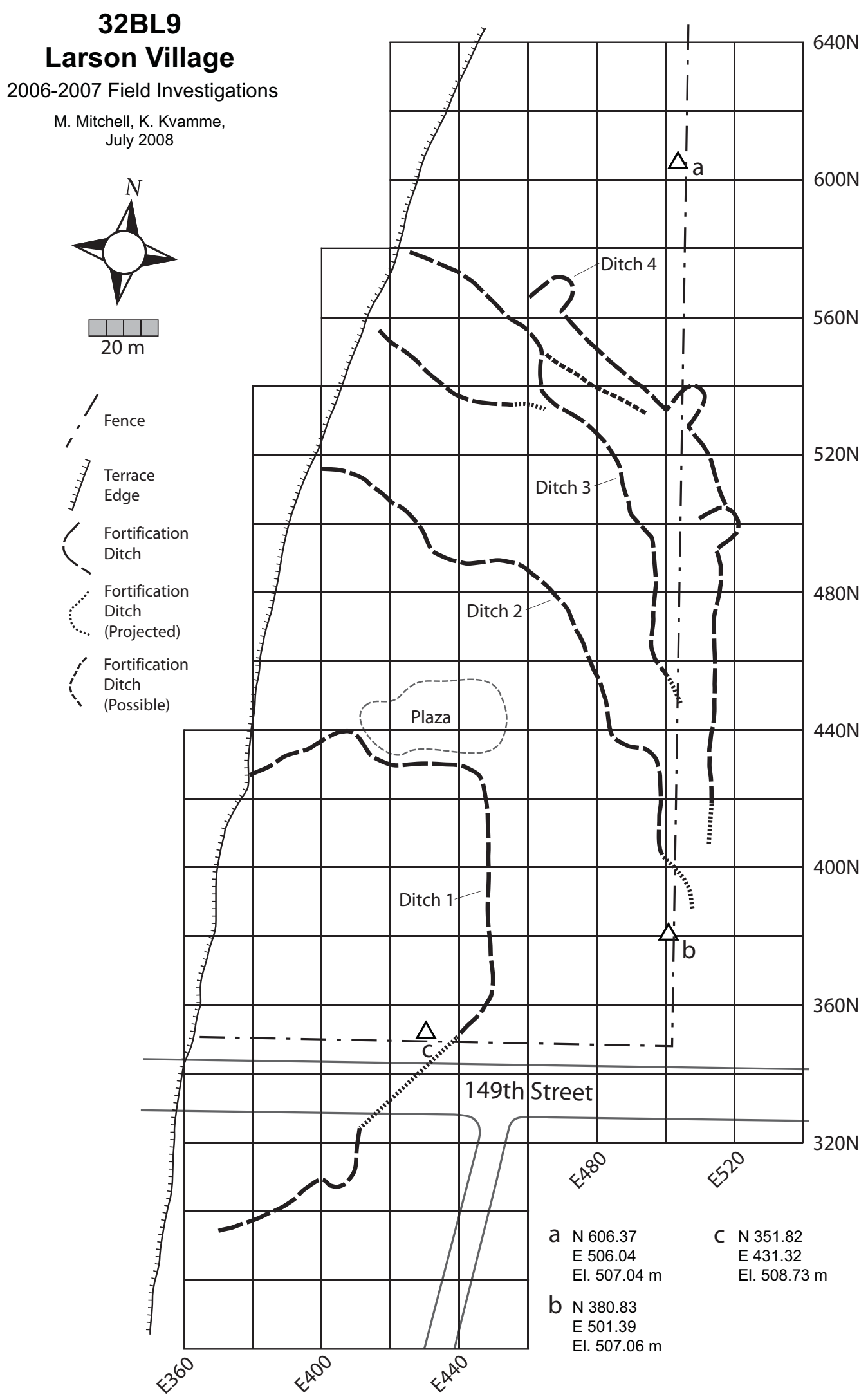

Figure 6.1. Map of Larson Village, showing the site's major features. 
Data from hand coring, along with high-resolution topographic data, demonstrated that a artificial earthen embankment roughly $50 \mathrm{~m}$ long, 12 to $15 \mathrm{~m}$ wide, and $20 \mathrm{~cm}$ high is present on the northern edge of the village, the first such feature documented in the Heart region. The function of this feature is not known.

Data collected during this project also have clarified the nature of several previously recognized features. Geophysical survey demonstrated that the large basin adjacent to the central core of the village lacks subsurface features or cultural deposits and hand coring confirmed that about $70 \mathrm{~cm}$ of sediment has been removed from this part of the site. This evidence suggests that the basin served both as an open, public space and as a source of material for the construction of earthlodges. The absence of storage pits or sheet midden deposits further suggests that the plaza was used throughout the history of the village, even after its residents withdrew inside Ditch 1.

Geophysical, topographic, and hand coring data demonstrated that the floors of at least 11 earthlodges are preserved in the village core. Several of these may have burned. By contrast, nearly all of the depressions located outside the village core represent the locations of sediment borrow basins, suggesting that the village existed for some time inside the confines of Ditch 1. These data also were used to pinpoint the locations of four of Alfred Bowers's excavation units and eight more recent potholes.

\section{Extent and Condition of Cultural Deposits}

Geophysical and coring data indicate that the site currently covers about 5.1 ha (12.7 ac). With a few exceptions (the linear mound, a low, circular mound, and a number of large pit features) the site is bounded by Ditch 4 . On the northern edge of the site, the track of Ditch 4 is relatively clear, but on the east it is poorly defined. Ditch 4 has not been located on the south, but cultural deposits do not appear to extend much beyond the modern residence there.

Different portions of the site have been impacted by post-abandonment disturbances to different degrees. Historical accounts and excavation data indicate that the northernmost section of the site has been plowed; however, the surface topography there does not seem to have been altered dramatically. By contrast, mounds and depressions on the eastern rim of the site have been completely obliterated by plowing. A county road ( $149^{\text {th }}$ Street), built in 1975 , cuts across the southern third of the site. South of $149^{\text {th }}$ Street, the site has been severely impacted by farming and by the construction of a road and several buildings. However, coring demonstrated that intact cultural deposits, including a central hearth, are present there. While a triangular portion of the site south of $149^{\text {th }}$ Street and west of the gravel driveway appears to have been bladed, perhaps to obtain construction fill, it appears that substantial intact deposits are preserved there.

Unprofessional digging appears to have taken place primarily in the northwestern corner of the village core, near the intersection of Ditch 1 with the cutbank. The cutbank continues to slump in this area, but it is not clear whether this is due to natural processes or to on-going looting. 


\section{Formation Processes}

Several of the test units opened up on the northern edge of the village in 2006 revealed the presence of a variety of small features, including postholes and small basins. These excavations also revealed that, in places, remnants of the pre-village soil, now buried at a depth of 30 to $60 \mathrm{~cm}$, are preserved. These data suggest that substantial portions of earthlodge floors or outdoor activity areas are preserved in this part of the site. At the same time, there is evidence from both the northern periphery and the center of the site for relatively widespread sediment borrowing and, presumably, transport. However, excavation, coring, and topographic mapping all suggest that, in the village core, the net rate of accumulation of cultural deposits approximately balanced, or slightly exceeded, the rate of borrowing and transport. Elsewhere, accumulation appears to have taken place more rapidly, and across a wider area, than borrowing and transport. As a result, preservation probably is best in the center of the settlement, where the most recently constructed houses are located, and on the periphery, where the first houses were constructed. Differences between Larson and Double Ditch in this respect are discussed below.

Analyses of modified stone and ceramic artifacts as well as botanical, faunal, and other remains indicate that many of the features investigated in 2006 are filled with secondary deposits. Especially within the fortification ditches, which together account for nearly 40 percent of the total volume of the 2006 excavations, artifacts and other remains are comparatively fragmented and occur at lower densities than in cache pits. Although not specifically demonstrated by the analyses conducted for this project, it seems likely that reusable or recyclable items were systematically removed from these deposits by the village's inhabitants. This might especially be true of Ditch 4, which likely was filled intentionally. In any case, these data are a reminder that depositional context needs to be considered when comparisons are drawn among collections.

\section{Chronology and Settlement History}

The available chronological data suggest, but do not conclusively demonstrate, that the village was founded about 1500 . There is no doubt that the settlement was built before 1650 . A calibrated distribution of the weighted mean of six radiocarbon dates spans the periods from 1460 to 1530 and 1550 to 1630. Ceramic types manufactured during the second half of the seventeenth century are all but absent, as are iron trade goods and glass beads. But uncertainty about the provenance of the cuprous artifacts in the collection, coupled with the difficulty of interpreting radiocarbon ages falling between about 400 B.P. and 250 B.P., means that a precise founding date cannot yet be determined. The balance of archaeological evidence (principally the make-up of the pottery assemblage and the presence of bastioned fortifications) supports a late fifteenth or early sixteenth century date.

Overall, the ceramic assemblage from Larson is similar to the Time Period 4 assemblage from Double Ditch. Both assemblages are dominated by Le Beau Classic variety rims. Transitional ware and Le Beau Sperry, Plain, and High Rim variety rims are absent or occur in very low numbers in both assemblages. Unclassified S-rim and straight-rim forms are common in both, as are decorated body sherds. However, there also are notable differences. Knife River ware is more common at Larson, while Le Beau Recurved variety is more common at Double Ditch. Early Srims and Stanton ware rims are more common at Larson. Taken together these data suggest that 
Larson may have been founded slightly earlier than Double Ditch. However, the make up of the Larson collection also may reflect spatial differences within the Heart region. Like Larson, all of the components assigned to Pottery Group 4, which is thought to date to the late 1400s and early 1500s, are located on the northern edge of the Heart region or in the Knife region (Ahler 2001).

Excavation data indicate that Ditch 4 very likely was built when the village was founded and that Ditch 3 is slightly younger. Ditch 1 has the clearest topographic expression, cuts through several pre-existing mounds, and winds around at least one pre-existing structure, indicating that it is the most recent. Pottery from the 2006 excavation appears to predate most of the pottery obtained by Alfred Bowers during his 1929 investigation, which in turn appears to predate the sample from the center of the village analyzed by Ahler (2001). Taken together, these results suggest that the village diminished progressively in size and, presumably, population over time. Interestingly, the central plaza appears to have remained open throughout the history of the village, even after the residents withdrew inside Ditch 1.

\section{Material Comparisons}

Like their neighbors at Double Ditch Village, the earliest residents of Larson Village made extensive use of smooth gray Tongue River silicified sediment (TRSS) for the production of stone tools. This material usually entered the site in the form of large flakes or cores, and was used primarily for the production of unpatterned flake tools and, possibly, large patterned bifaces. By contrast, Knife River flint (KRF) was brought to the site in the form of small cobbles, tool preforms, or finished tools, and was used most often for the production of patterned tools, including arrow points, knives, and scrapers. Similar technological patterns are evident in the Double Ditch chipped stone assemblage. These data suggest that the east bank villagers at Double Ditch and Larson enjoyed comparatively direct access to sources of good quality TRSS south and west of the Heart River, but that access to other sources to the west and northwest was more limited or indirect.

Data on pottery and stone tools also reveal intriguing parallels with Huff Village, a large, fortified, fifteenth-century settlement located on the west bank of the Missouri some $45 \mathrm{~km}$ below Larson. The clearest similarities can be seen in the pottery assemblages from the two sites. Both contain a notably large number of tool-impressed straight-rim vessels (with and without braces), as well as vessels bearing complex trailed decoration on the shoulder (Ahler and Johnson 2000). Both include small numbers of Extended Coalescent imports. Flintknappers living in both communities used large quantities of smooth gray TRSS, even though Larson is much farther from likely quarry sites. More strikingly, excavations at both Huff and Larson produced large numbers of diorite celts; limited evidence from Larson suggests that they may have been manufactured there. These similarities hint at the possibility of a historical relationship between these communities.

Analysis of unmodified vertebrate remains underscores important similarities and differences among Heart region and Knife region faunal assemblages. Although excavation strategies and differences in the methods for studying sizes G4 and G5 remains may be partly responsible for these patterns, several conclusions seem warranted. Without question, bison was the most important meat source throughout the northern Middle Missouri. However, communities in the Heart region appear to have enjoyed a more diverse diet than their neighbors in the Knife region. Fishing seems to have been an especially important activity among west bank villagers at 
Slant, Scattered, and Boley villages. The 2006 collection from Larson is notable for the very high number of large canid bones, an observation also made by Bowers, although the meaning of this result is not clear.

Data on botanical remains from Larson confirm the importance of marshelder cultivation by fifteenth and sixteenth century Heart region communities. In addition to the three primary tropical cultigens, the residents of Larson Village also grew another North American domesticate, sunflower. They supplemented this suite of cultivated plants with a wide variety of wild fruits and seeds, including grape, plum, chokecherry, and buffaloberry.

\section{Comparisons to Double Ditch Village}

This project has demonstrated several striking similarities between Larson and Double Ditch villages. Particularly in view of the previously observed differences among the Heart River towns, it is not unreasonable to describe these two sites as "sister settlements." An unknown portion of Larson has been lost to bank erosion, but it may once have been nearly as large as Double Ditch. Like Double Ditch, Larson is surrounded by four concentric fortifications, the outermost of which was constructed with bastions. At Double Ditch, the fortifications were built sequentially, beginning in the last few decades of the 1400s, with the size of the village contracting progressively over time. Ceramic, radiocarbon, and geophysical data suggest that Larson too was founded in the late fifteenth or early sixteenth century and that it decreased in size over time. Both villages are surrounded by a ring of high, curvilinear mounds. Many of the largest mounds are aligned with the sites' fortification systems, suggesting that they may have been used partly for defensive purposes. Both villages contain large, open plazas that likely functioned as public spaces for social and ceremonial activities and as sediment borrow areas. Residents of both communities engaged in similar subsistence practices, utilized similar stone tool raw material sources, and produced similar ceramic forms.

Nevertheless, there also are differences between the two sites. At Larson, living surfaces and small features are preserved on the periphery of the settlement, but at Double Ditch, cultural features and natural soil horizons on the periphery have been obliterated to a depth of 50 to $80 \mathrm{~cm}$. The process or processes responsible for this vertical churning and homogenization are not known, but gardening may be partly responsible. In any case, this difference suggests that the outskirts of the two villages were used by later residents in rather different ways.

Extensive earth borrowing — for mound construction, earthlodge covering, and possibly for ceremonial village cleansing — was a frequent and prominent activity at Double Ditch. By contrast, at Larson, the presence of moderate accumulations of cultural debris above the pre-village surface indicates that such "planar borrowing" did not occur on the same scale. In particular, sediment borrowing and transport at Double Ditch seems to have been connected to the construction of mounds incorporated into the village defenses. The comparative absence of similar sediment borrowing and transport at Larson may indicate that rather different processes were responsible for the formation of the site's superficially similar mounds. It also suggests that large-scale remodeling of the village, undertaken perhaps in conjunction with periodic rites of community renewal, was more prominent at Double Ditch. 


\section{Recommendations for Future Work}

Except for Double Ditch, Larson may be the best preserved of the post-1500 towns in the Heart region. More than half the site is in good condition. Moreover, it appears that Larson may be unsurpassed in its preservation of cultural deposits dating to the 1500s. For that reason, additional research at Larson could prove to be critical for understanding the decisive cultural and economic changes that began in the Heart region at that time. The sixteenth century marks the beginning of a dramatic increase in settlement occupation duration. Many of the large villages occupied at the end of the 1700s were founded during the 1500s, whereas earlier villages generally were occupied only for one or two generations. At about the same time, the long-rectangular lodges that had been constructed in the Knife and Heart regions since the 1200s were replaced, apparently rapidly, by circular lodges. The 1500s also witnessed an increasing volume of long-distance exchange, culminating in the introduction early in the seventeenth century of European trade goods.

Lodge floors and features also appear to be well preserved inside Ditch 1. While limited ethnohistorical data are available bearing on the size and make up of the eighteenth-century communities at Heart River, little is known about the archaeology of this period. Data from excavations in the village core would contribute to a better understanding of technological change, architectural variability, and of regional and interregional trade relationships during the 1700s. They might also help determine when and how the settlement was abandoned.

However, to realize the potential of this research new chronological tools will be necessary. Foremost among these is a comprehensive, regional provenance study of cuprous artifacts. Scholars have generally assumed that all of the cuprous artifacts recovered from northern Middle Missouri villages were made from European copper or brass and therefore post-date 1600, or perhaps slightly later. The data from Larson and from other Heart region villages (e.g. Ahler 2005), now call that assumption into question. Systematically obtained data on the elemental composition of these artifacts may help differentiate contexts dating to the 1500s from those dating to the 1600s or later.

New absolute methods also are needed. These might include thermoluminscent dating of ceramic remains or archaeomagnetic dating of hearth features. Unfortunately, both of these methods have sometimes proven to be unreliable and for that reason should be rigorously tested before they are broadly applied. Nevertheless, a well-designed excavation and analysis program incorporating these methods in conjunction with more conventional AMS radiocarbon assays may make it possible to separate early sixteenth century contexts from late sixteenth century contexts. These methods may also be useful for isolating eighteenth-century deposits. The ability to construct a finer-grained chronology will be critical for any future work at the site.

Targeted test excavations also might be used to refine the occupational history of the settlement. Although it seems clear that the village contracted over time, it is not known when Ditch 2 or Ditch 1 was built. Such excavations might also be used to better understand sediment borrowing, transport, and accumulation. The current interpretation is based in part on the assumption that the pre-village surface was approximately level. Detailed data on the sedimentary structure of the terrace and on the extent of sediment removal and accumulation in various parts of the village would enable a more comprehensive and detailed history of the site. 
Archaeological deposits at the site currently are stable. Although portions of the village continue to be plowed, the on-going impact from such activities is negligible. The best preserved portion is used as a lightly-stocked horse pasture, and no water developments are located within the boundaries of the site. Overall, natural erosion of the cutbank appears to minimal. However, significant slumping of cultural deposits was observed during 2006 and 2007 where Ditch 1 intersects the edge of the terrace. This slumping may be due to natural erosion or to small-scale unprofessional digging. In either case, the SHSND should consider establishing an informal monitoring program to periodically assess the site’s condition. 


\section{References Cited}

Ahler, Stanley A. (editor)

2002 Prehistory on First Street, NE: The Archaeology of Scattered Village in Mandan, North Dakota. Research Contribution No. 40. PaleoCultural Research Group, Flagstaff, Arizona. Submitted to the City of Mandan, North Dakota, and the North Dakota Department of Transportation, Bismarck.

2003 Archaeological Investigations During 2001 and 2002 at Double Ditch State Historic Site, North Dakota. Research Contribution No. 56. PaleoCultural Research Group, Flagstaff, Arizona. Submitted to the State Historical Society of North Dakota, Bismarck.

2004 Archaeological Investigations During 2003 at Double Ditch State Historic Site, North Dakota. Research Contribution No. 60. PaleoCultural Research Group, Flagstaff, Arizona. Submitted to the State Historical Society of North Dakota, Bismarck.

2005 Archaeological Investigations During 2004 at Double Ditch State Historic Site, North Dakota. Research Contribution No. 65. PaleoCultural Research Group, Flagstaff, Arizona. Submitted to the State Historical Society of North Dakota, Bismarck.

2006 Geophysical Survey and Test Excavation During 2005 at Boley Village (32MO37), North Dakota. Research Contribution No. 74. PaleoCultural Research Group, Flagstaff, Arizona. Submitted to the State Historical Society of North Dakota, Bismarck.

Ahler, Stanley A.

2001 Analysis of Curated Plains Village Artifact Collections from the Heart, Knife, and Cannonball Regions, North Dakota. Research Contribution No. 42. PaleoCultural Research Group, Flagstaff, Arizona. Submitted to the State Historical Society of North Dakota, Bismarck.

2002 Summary and Conclusions. In Prehistory on First Street, NE: The Archaeology of Scattered Village in Mandan, North Dakota, edited by Stanley A. Ahler, pp. 18.1-18.5. Research Contribution No. 40. PaleoCultural Research Group, Flagstaff, Arizona. Submitted to the City of Mandan, North Dakota, and the North Dakota Department of Transportation, Bismarck.

2005 Analysis of Trade Artifacts. In Archaeological Investigations During 2004 at Double Ditch State Historic Site, North Dakota, edited by Stanley A. Ahler, pp. 295-313. Research Contribution No. 65. PaleoCultural Research Group, Flagstaff, Arizona. Submitted to the State Historical Society of North Dakota, Bismarck.

Ahler, Stanley A., and Craig M. Johnson

2000 Pottery Analysis. In New Geophysical and Archaeological Investigations at Huff Village State Historic Site (32MO11), Morton County, North Dakota, edited by Stanley A. Ahler and Kenneth L. Kvamme, pp. 67-79. Research Contribution No. 26. PaleoCultural Research Group, Flagstaff, Arizona. Submitted to the State Historical Society of North Dakota, Bismarck.

Bowers, Alfred W.

1940 Missouri River Earthlodge Archaeology of North and South Dakota. Ms. on file, Logan Museum of Anthropology, Beloit College, Beloit, Wisconsin.

Kvamme, Kenneth L., and Stanley A. Ahler

2007 Integrated Remote Sensing and Excavation at Double Ditch State Historic Site, North Dakota. American Antiquity 72(3):539-561. 
Wood, W. Raymond

1967 An Interpretation of Mandan Culture History. Smithsonian Institution, Bureau of American Ethnology Bulletin 198. River Basin Surveys Papers No. 39. U.S. Government Printing Office, Washington, D. C. 